\section{WASTE \\ MANAGEMENT \\ PROGRAM}

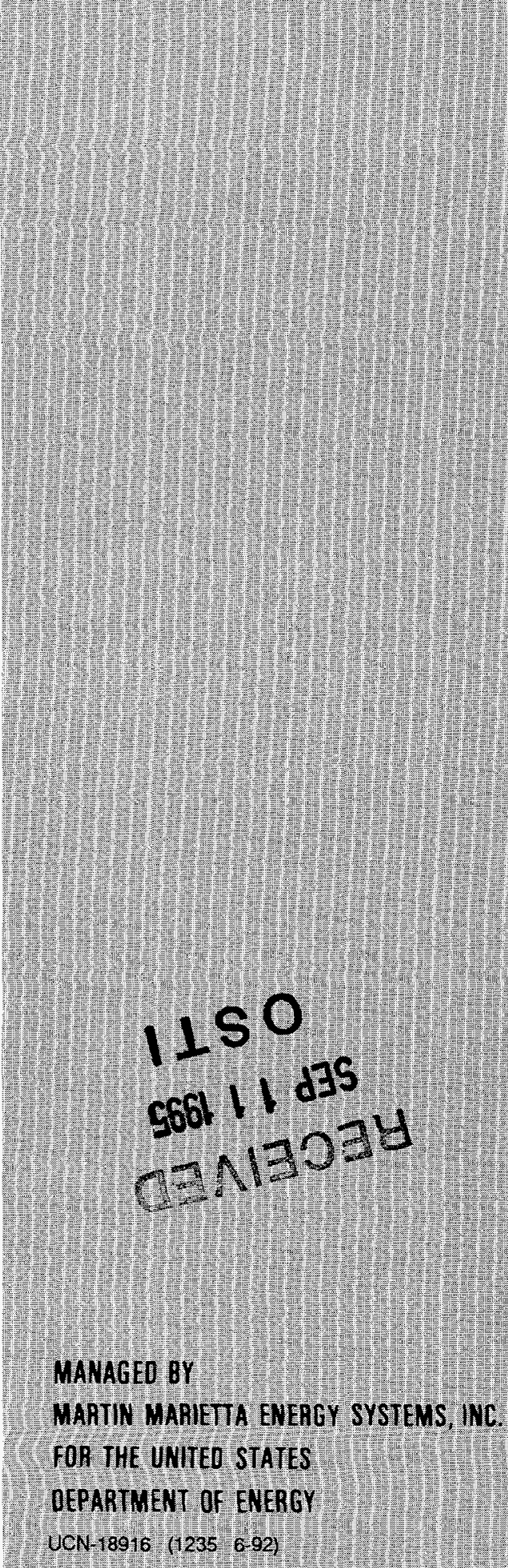

Sludge Application and Monitoring Program on the Oak Ridge Reservation, 1986 through 1993 


\section{DISCLAIMER}

This report was prepared as an account of work sponsored by an agency of the United States Government. Neither the United States Government nor any agency thereof, nor any of their employees, makes any warranty, express or implied, or assumes any legal liability or responsibility for the accuracy, completeness, or usefulness of any information, apparatus, product, or process disclosed, or represents that its use would not infringe privately owned rights. Reference herein to any specific commercial product, process, or service by trade name, trademark, manufacturer, or otherwise, does not necessarily constitute or imply its endorsement, recommendation, or favoring by the United States Government or any agency thereof. The views and opinions of authors expressed herein do not necessarily state or reflect those of the United States Government or any agency thereof. 
Energy Systems Waste Management Organization

\title{
Sludge Application and Monitoring Program on the Oak Ridge Reservation, 1986 through 1993
}

\author{
C. A. Gunderson \\ H. L. Boston \\ H. Van Miegroet \\ J. L. Morris \\ I. L. Larsen \\ A. E. Walzer \\ T. C. Adler \\ D. M. Bradburn \\ M. Huq
}

Date Issued-August 1995

This document has been approved for release to the public by:
Prepared by

Energy Systems Waste Management Organization

Oak Ridge, Tennessee 37831-7357

Prepared for

U.S. Department of Energy

Office of Environmental Restoration and Waste Management under budget and reporting code EW 31

LOCKHEED MARTIN ENERGY SYSTEMS, INC.

managing the

Oak Ridge K-25 Site

Oak Ridge Y-12 Plant

Oak Ridge National Laboratory

under contract DE-AC05-84OR21400

for the

U.S. DEPARTMENT OF ENERGY 
Author Affiliations

Carla A. Gunderson, Marion Huq, and Ingvar L. Larsen are members of the Lockheed Martin Energy Systems, Inc., Environmental Sciences Division at Oak Ridge National Laboratory, Oak Ridge, Tennessee. Harry L. Boston is a member of the Lockheed Martin Energy Systems, Inc., Environmental Restoration Office at Oak Ridge National Laboratory, Oak Ridge, Tennessee. Ann E. Walzer is a member of the Lockheed Martin Energy Systems, Inc., Central Environmental Compliance Division at Oak Ridge National Laboratory, Oak Ridge, Tennessee. Dennis M. Bradburn is a member of the Lockheed Martin Energy Systems, Inc., Forestry Management Department, Plant and Equipment Division at Oak Ridge National Laboratory, Oak Ridge, Tennessee. Helga Van Miegroet is affiliated with the Department of Forest Resources, Utah State University, Logan, Utah. Jeavita L. Morris is affiliated with Jaycor, Inc. Tim C. Adler is affiliated with Bechtel National, Inc., Oak Ridge, Tennessee.

The Environmental Sciences Division and the Environmental Restoration Office at Oak Ridge National Laboratory, Oak Ridge, Tennessee, assigned their document numbers to an earlier draft of this document. These numbers are Environmental Sciences Division Publication No. 4445 and ORNL/TM-11601. 


\section{DISCLAIMER}

Portions of this document may be illegible in electronic image products. Images are produced from the best available original document. 


\section{CONTENTS}

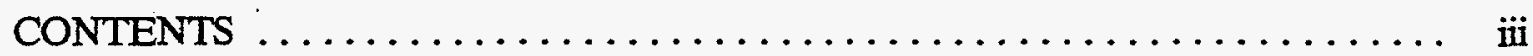

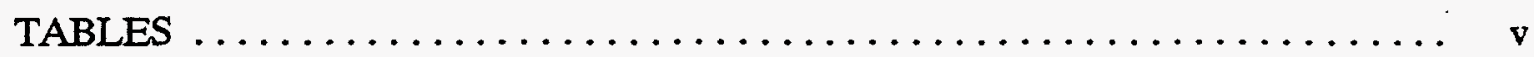

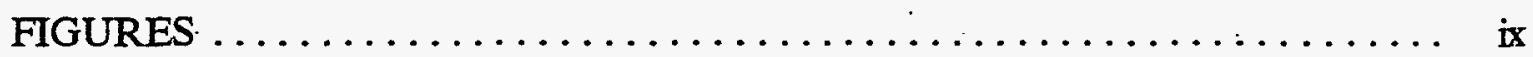

ABBREVIATIONS $\ldots \ldots \ldots \ldots \ldots \ldots \ldots \ldots \ldots \ldots \ldots \ldots \ldots \ldots \ldots \ldots \ldots \ldots$

ACKNOWLEDGMENTS $\ldots \ldots \ldots \ldots \ldots \ldots \ldots \ldots \ldots \ldots \ldots \ldots \ldots \ldots \ldots \ldots \ldots \ldots$

EXECUTTVE SUMMARY $\ldots \ldots \ldots \ldots \ldots \ldots \ldots \ldots \ldots \ldots \ldots \ldots \ldots \ldots \ldots \ldots$

1. INTRODUCTION: HISTORY OF SLUDGE APPLICATION AND MONITORING ON THE OAK RIDGE RESERVATION $\ldots \ldots \ldots \ldots \quad 1$

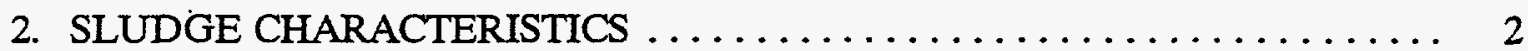

2.1 SAMPLING: PARAMETERS OF INTEREST AND METHODS $\ldots \ldots \ldots \quad 2$

2.2 VARIATION IN SLUDGE CHARACTERISTICS OVER TIME $\ldots \ldots \ldots, 2$

2.3 COMPARISON WITH OTHER MUNICIPAL SLUDGES $\ldots \ldots \ldots \ldots, 5$

2.4 COMPARISON WITH REGULATORY LIMTTS $\ldots \ldots \ldots \ldots \ldots \ldots, 8$

3. SLUDGE APPLICATION: METHODS, APPLICATION

SITES, ENVIRONMENTAL MONITORING $\ldots \ldots \ldots \ldots \ldots \ldots \ldots \ldots \ldots, 11$

3.1 SLUDGE APPLICATION $\ldots \ldots \ldots \ldots \ldots \ldots \ldots \ldots \ldots \ldots \ldots \ldots \ldots \ldots \ldots \ldots$

3.2 APPLICATION SITES $\ldots \ldots \ldots \ldots \ldots \ldots \ldots \ldots \ldots \ldots \ldots \ldots \ldots \ldots \ldots \ldots \ldots \ldots \ldots$

3.3 MONITORING AT EACH SITE $\ldots \ldots \ldots \ldots \ldots \ldots \ldots \ldots \ldots \ldots 20$

3.4 APPLICATION RATE AND CUMULATTVE

LOADING OF SPECIFIC CONSTITUENTS:

COMPARISON WITH REGULATORY LIMITS $\ldots \ldots \ldots \ldots \ldots \ldots, 20$

4. SOIL $\ldots \ldots \ldots \ldots \ldots \ldots \ldots \ldots \ldots \ldots \ldots \ldots \ldots \ldots \ldots \ldots \ldots \ldots \ldots \ldots \ldots \ldots, 22$

4.1 METHODS OF SAMPLING AND ANALYSIS $\ldots \ldots \ldots \ldots \ldots \ldots \ldots 22$

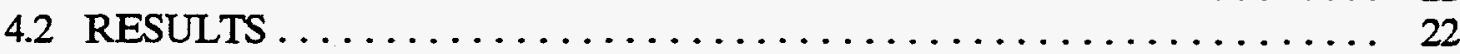

4.2.1 Soil Conditioning-Nitrogen, $\mathrm{pH}$,

Cation Exchange Capacity $\ldots \ldots \ldots \ldots \ldots \ldots \ldots \ldots \ldots \ldots \ldots \ldots \ldots \ldots \ldots \ldots, 22$

4.2.2 Metals and radionuclides $\ldots \ldots \ldots \ldots \ldots \ldots \ldots \ldots \ldots \ldots \ldots \ldots \ldots \ldots \ldots, 24$

4.2 .3 Organics .................................. 27

4.2 .4 Summary $\ldots \ldots \ldots \ldots \ldots \ldots \ldots \ldots \ldots \ldots \ldots \ldots \ldots \ldots \ldots \ldots \ldots \ldots \ldots, 28$

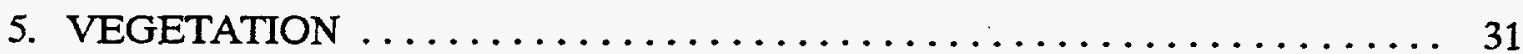

5.1 METHODS OF SAMPLING AND ANALYSIS $\ldots \ldots \ldots \ldots \ldots \ldots \ldots, 31$

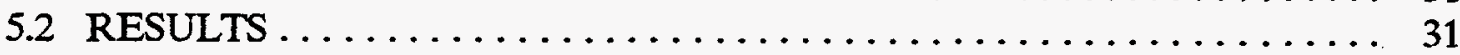




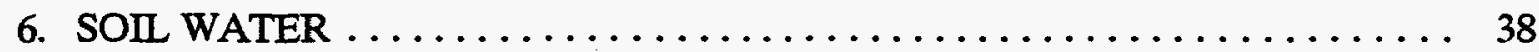

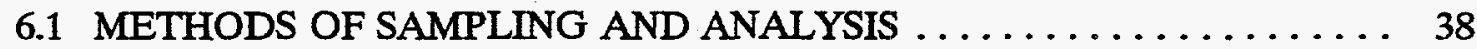

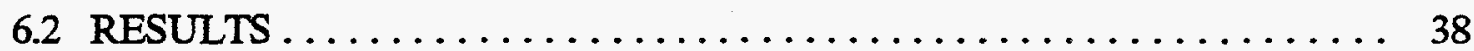

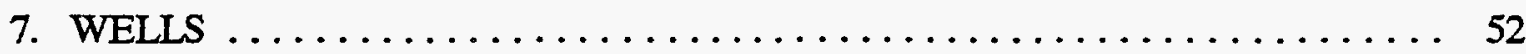

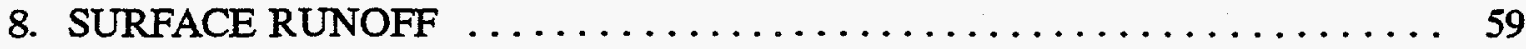

8.1 METHODS OF SAMPLING $\ldots \ldots \ldots \ldots \ldots \ldots \ldots \ldots \ldots \ldots \ldots \ldots$

8.2 RESULTS . . . . . . . . . . . . . . . . . . . . . . . 59

REFERENCES . . . . . . . . . . . . . . . . . . . . . . . 89

Appendix A METHODS OF SLUDGE ANALYSIS FOR RADIONUCLIDE CONTENT AT OAK RIDGE NATIONAL LABORATORY . . . . . A A-1

Appendix B. WEEKLY SLUDGE RADIOISOTOPE ANALYSIS . . . . . . . . B-1 


\section{TABLES}

2.1 Yearly average concentrations of nutrients and metals

in Oak Ridge sewage sludge, $1988-1993 \ldots \ldots \ldots \ldots \ldots \ldots \ldots \ldots \ldots \ldots$

2.2 Mean concentrations of metals in Oak Ridge sewage

sludge, $1984-1986 \ldots \ldots \ldots \ldots \ldots \ldots \ldots \ldots \ldots \ldots \ldots \ldots \ldots . \ldots$

2.3(a) Yearly average concentrations of radionuclides in

Oak Ridge sewage sludge, mid-1988 through $1992 \ldots \ldots \ldots \ldots \ldots \ldots 6$

2.3(b) Yearly average concentrations of radionuclides in

Oak Ridge sewage sludge, mid-1988 through 1992 . . . . . . . . . . . . . 6

2.4 Comparison of concentrations of various elements in

Oak Ridge sewage sludge with those in other municipal

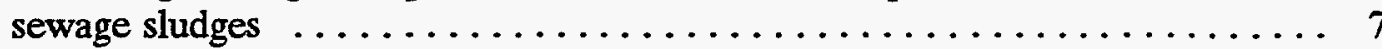

2.5. Radionuclides in regional wastewater treatment plant sludges $\ldots \ldots \ldots \ldots 8$

2.6. Oak Ridge sludge composition in comparison to pollutant

limits from EPA regulations (40 CFR 503) for sludge constituents ....... 10

3.1 Sludge application sites and monitoring matrix $\ldots \ldots \ldots \ldots \ldots \ldots \ldots \ldots$

$3.2 \quad$ Average concentration of metals in sludge $\ldots \ldots \ldots \ldots \ldots \ldots \ldots \ldots 21$

3.3 Total sludge applied ( $\mathrm{kg} / \mathrm{ha})$ on each site and cumulative metal loading $\ldots \ldots 21$

4.1 Concentrations of soil nitrogen (total Kjehldahl $\mathrm{N}, \mathrm{mg} / \mathrm{kg}$ )

at eight sludge application sites

4.2 Concentrations of soil nitrogen (TKN, total Kjeldahl N, ppm), cation exchange capacity (CEC, meq/100 g soil), and soil $\mathrm{pH}$ at seven sludge application sites and associated reference sites

4.3 Concentrations of ICP analytes, uranium, and radionuclides in soil at the Rogers site, at two soil depths, from sludge-treated and

reference soils

4.4 Concentrations of metals and nitrogen at two depths in Pine

Plantation soils on sludge-treated and reference

(untreated) sites

4.5 Radionuclides at three depths in Pine Plantation soils on sludge-treated and reference (untreated) sites 
4.6 Concentrations of metals in the upper $0-15 \mathrm{~cm}$ in soils at the Cottonwood, Scarboro, and Hayfield 1 \& 2 sites on sludge-treated and reference (untreated) areas

4.7 Mean ${ }^{99} \mathrm{Tc},{ }^{90} \mathrm{Sr}$, and total uranium in soils in sludge application areas (4 grassy fields and one wooded area) and associated reference areas

4.8 Radionuclides in soils in sludge application areas

(4 grassy fields and one wooded area) and associated

reference areas

5.1 Concentrations of metals and nitrogen in herbaceous vegetation (grasses and weeds) from three sludge application sites and reference areas

5.2 Concentrations of ICP analytes, including metals, and nitrogen in pine needles from sludge application and reference plots in the Pine Plantation

5.3 Concentrations of ICP analytes and nitrogen in berries from the Pine Plantation (dates of application: 6/88-6/89)

5.4 Radionuclides in vegetation on sludge application and reference areas (dry weight basis) $\ldots \ldots \ldots \ldots \ldots \ldots \ldots \ldots \ldots \ldots \ldots$

6.1 Soil water chemistry (including metals) from lysimeters at the Pine Plantation site

6.2 Soil water chemistry (including metals) from deep lysimeters at the Pine Plantation site

6.3 Soil water chemistry and metals at the Rogers site, measured in 40 to $60 \mathrm{~cm}$ deep lysimeters.

6.4 Water chemistry and metals in 3-ft lysimeters (sampling 40-60 cm depth) at the Cottonwood Site

6.5 Soil water metal concentrations at the McCoy and Sycamore sites, from lysimeter samples

6.6 Radionuclides measured in lysimeters at the Pine Plantation Site at the end of the sludge application period (6/88 through 6/89), and one sample before sludge application began $\ldots \ldots \ldots \ldots \ldots \ldots \ldots \ldots \ldots \ldots \ldots \ldots$

7.1 Groundwater chemistry at the Pine Plantation Site $\ldots \ldots \ldots \ldots \ldots \ldots$

7.2 Metal concentrations ( $\mathrm{mg} / \mathrm{L}$ ) in wells at the Pine Plantation during and for 9 months after sludge application . . . . . . . 54 
7.3 Radionuclides measured in wells at the Pine Plantation

Site during and after sludge application

8.1 Surface water chemistry and nutrients at the Cottonwood Site . . . . . . . 62

8.2 Surface water chemistry and nutrients at the Watson Road Site . . . . . . 63

8.3 Surface water chemistry and nutrients at the Rogers Site $\ldots \ldots \ldots \ldots \ldots$

8.4(a) Water chemistry and nutrients in surface runoff at the

Pine Plantation Site . . . . . . . . . . . . . . . . . . . 66

8.4(b) Runoff collections on two typical dates; grab samples $\ldots \ldots \ldots \ldots \ldots \ldots 7$

8.4(c) Runoff collections on two typical dates; compositors

plus grab samples

8.5 Metals in grab samples of surface runoff at the McCoy Site

for two dates after sludge application

8.6(a) Metal concentrations in surface runoff at the Rogers Site,

for two samples

8.6(b) Metal concentrations in grab samples of surface runoff

at the Rogers site

8.7(a) Metals in surface runoff at the Pine Plantation Site

(Ag through $\mathrm{Cr}$ )

8.7(b) Metals in surface runoff at the Pine Plantation Site

(Cu through $\mathrm{P}$ )

8.7(c) Metals in surface runoff at the Pine Plantation Site

$(\mathrm{Pb}$ through $\mathrm{Zn})$

8.8 Metals in surface runoff at the Cottonwood Site $\ldots \ldots \ldots \ldots \ldots \ldots \ldots$

8.9 Mercury in surface runoff at the Rogers Site $\ldots \ldots \ldots \ldots \ldots$

8.10 Radionuclides in surface runoff at: Rogers, Pine

Plantation, Cottonwoods and McCoy sites

8.11 Biological oxygen demand (mg/L) and fecal coliform bacteria (colonies $/ 100 \mathrm{~mL}$ ) in surface runoff from the Cottonwood, Pine Plantation, and Rogers sites 



\section{FIGURES}

3.1 Map of the Oak Ridge Reservation and surrounding area showing the sludge application sites.

3.2 The McCoy sludge application area showing reference area and location of proportional flow sample .

3.3 Area 2, with the Pine Plantation at the top, the High Pasture in the center, and the Rogers Site at the bottom.

3.4 Detail of Pine Plantation showing application area and reference area, well, and runoff collection sites

3.5 Area 3, showing the Upper Hayfield Site, the Scarboto Site (two sections), and the Upper Hayfield 2 Site

5.1 Response of herbaceous plants to sludge application

7.1 Nitrate in wells at the Pine Plantation Site before, during, and after the sludge application period 58 



\section{ABBREVIATIONS}

$\begin{array}{ll}\text { AA } & \text { atomic absorption spectrophotometry } \\ \text { BOD } & \text { biological oxygen demand } \\ \text { CEC } & \text { cation exchange capacity } \\ \text { DOE } & \text { U. S. Department of Energy } \\ \text { EPA } & \text { United States Environmental Protection Agency } \\ \text { ESD } & \text { Environmental Sciences Division } \\ \text { ICP } & \text { inductively coupled plasma spectrometry } \\ \text { IG } & \text { intrinsic germanium } \\ \text { MDL } & \text { method detection limit } \\ \text { NIST } & \text { National Institute for Standards and Testing } \\ \text { NPDES } & \text { National Pollutant Discharge Elimination System } \\ \text { ORAU } & \text { Oak Ridge Associated Universities } \\ \text { ORNL } & \text { Oak Ridge National Laboratory } \\ \text { ORR } & \text { Oak Ridge Reservation } \\ \text { PSRP } & \text { process to significantly reduce pathogens } \\ \text { RCRA } & \text { Resource Conservation and Recovery Act } \\ \text { Std } & \text { standard deviation } \\ \text { TKN } & \text { total Kjeldahl nitrogen }\end{array}$




\section{ACKNOWLEDGMENTS}

The authors wish to thank the City of Oak Ridge (particularly Jack Robinson and the staff at the Oak Ridge Wastewater Treatment Plant) for their financial support, participation, and cooperation. Thanks also to the Waste Management Division (U.S. Department of Energy, Oak Ridge Operations) for additional financial support for monitoring efforts and report preparation, and the Environmental Sciences Division (Oak Ridge National Laboratory) and Energy Systems Waste Management Organization for further support of report preparation. Helpful technical review of this document was provided by Elizabeth Will, Joe Birchfield, Larry Jones, and Sam Howard. The research was sponsored jointly by the City of Oak Ridge, and the U.S. Department of Energy, under contract DEAC05-84OR21400 with Lockheed Martin Energy Systems. 


\section{EXECUTIVE SUMMARY}

Municipal sewage sludge has been applied to forests and pastures on the DOE (U.S. Department of Energy) Oak Ridge Reservation (ORR) since 1983 as a method of both disposal and beneficial reuse. Application was carried out under State of Tennessee permits issued to the City of Oak Ridge for land disposal of sewage sludge. In conjunction with these applications, information has been collected concerning sludge quantity and characteristics, soil parameters, soil water constituents, groundwater quality, surface runoff water quality, and various chemical constituents in vegetation on application sites. This information provides (1) a record of sludge application on the DOE ORR, and (2) documentation of changes in soil parameters following sludge application. The information also provides a basis for evaluating the implications of the land application of municipal sewage sludge for soil and water quality and for evaluating the fate of sludge constituents when sludge is either sprayed onto or injected into pasture sites or appled to the surface of forested sites. This report covers in detail sludge applications conducted from 1986 through 1993, with some data from the period between 1983 and 1986.

Land application, a common means of disposal for municipal sewage sludge in the United States, has been recommended by the U. S. Environmental Protection Agency as a desirable alternative for disposal of ORR waste. Municipal sewage sludge is in many ways similar to dilute animal manure fertilizer, but it alsos contains metals, organic chemicals, human pathogens, and other constituents reflective of inputs into the municipal sewage treatment plant. When applied to land, nutrients in the sludge improve soil fertility, and minerals and organic matter in the sludge improve soil structure. Under optimal conditions, metals are immobilized, and organic chemicals and pathogens are immobilized or destroyed. If the sludge is not managed effectively, however, sludge constituents (metals, nutrients, and pathogens) have the potential to affect human health and the environment.

Compared to typical municipal sludges, anaerobically digested liquid sludge (2\% to $4 \%$ solids) from the City of Oak Ridge had a relatively high nitrogen content (8\% dry weight) and average-to-low concentrations of potentially problematic metals. Few potentially hazardous organic chemicals were detected in the sludge and, when found, were at very low concentrations. Oak Ridge sludge is somewhat unique in that it contains radionuclides $\left({ }^{137} \mathrm{Cs}\right.$, ${ }^{60} \mathrm{Co},{ }^{131} \mathrm{I}$, uranium isotopes, ${ }^{90} \mathrm{Sr}$, and, occasionally, ${ }^{99} \mathrm{Tc}$ ) at concentrations much higher than in typical municipal sludges; consequently, DOE, the City of Oak Ridge, and the State of Tennessee established sludge loading rates to avoid the accumulation of radionuclides in soil to levels that cause future problems. On the initial application sites, sludge was applied at rates of 44 to $48 \mathrm{Mg} / \mathrm{ha}$ (19 to 21 tons/acre), on a dry weight basis. In 1989, the city began to limit sludge loading to a very conservative $10 \mathrm{Mg} / \mathrm{ha}$ ( 4.4 tons/acre)/year and a lifetime maximum of $34 \mathrm{Mg} / \mathrm{ha}$ (15 tons/acre), dry weight, based upon concern for radionuclide accumulation in soils. Subsequently, lifetime maximum loading has been extended to approximately 22 tons/acre. These loading rates are substantially lower than the sludge loading rates allowed by either federal regulations (Title 40, Code of Federal Regulation, Sect. 503.13), based on metal concentrations in the sludge] or Tennessee Department of Environment and Conservation regulations, which also take into account available nitrogen loading. The sludge 
loading rate allowed by the state Land Application Approval is 5 tons/acre/year for a maximum of 10 years, for a total of 50 tons/acre $(112 \mathrm{Mg} / \mathrm{ha})$.

Measurement of soil constituents following sludge application indicated that sludge constituents were (1) largely retained in the upper $15 \mathrm{~cm}$ of soil, and, (2) with the exception of $\mathrm{N}, \mathrm{Zn}, \mathrm{Cd}, \mathrm{Cu}, \mathrm{Hg}$, and selected radionuclides, sludge application did not substantially alter the concentrations of soil constituents. Concentrations of $\mathrm{Zn}$ and $\mathrm{Cu}$ were approximately doubled, and concentrations of $\mathrm{Hg}$ and $\mathrm{Cd}$ increased by several fold. These changes are not anticipated to have any adverse effects on land use, plant growth, or soil organisms. Although nitrogen was added at rates of up to $3000 \mathrm{~kg} / \mathrm{ha}$, variability in soil nitrogen concentrations made it difficult to show significant differences in soil nitrogen concentrations within the upper $15 \mathrm{~cm}$ of soil. Apparently, much of the added nitrogen was lost through volatilization, plant uptake, and other mechanisms. Radionuclides were quantitatively retained in the soil; that is, almost all of the radionuclides in the sludge could be accounted for in the upper 15 $\mathrm{cm}$ of the soil. The concentration of uranium and ${ }^{137} \mathrm{Cs}$ in the upper $15 \mathrm{~cm}$ increased by less than a factor of two. The concentrations of ${ }^{60} \mathrm{Co}$ in the soil increased substantially, compared to soils where sludge has not been applied, which usually do not contain ${ }^{60} \mathrm{Co}$. However, final concentrations of ${ }^{60} \mathrm{Co}$ in the soil were low in comparison to other radionuclides in the soil. It could not be determined whether concentrations of other sludge-related radionuclides increased in soils as a result of sludge application. Concentrations of radionuclides in soils on sludge application sites were low enough that they did not preclude unrestricted use of those sites.

Soil water constituents provide an indication of the fraction of material in soils that is easily mobile and readily available to plants. Measurements of soil water constituents (at about 40 to $60 \mathrm{~cm}$ depth) on sludge application sites and reference plots were made during and following sludge application. Sludge application increased the conductivity and alkalinity of soil water. Concentrations of $\mathrm{Ca}, \mathrm{K}, \mathrm{Mg}, \mathrm{Mn} . \mathrm{Na}, \mathrm{Zn}, \mathrm{NO}_{3}{ }^{-}$, and $\mathrm{SO}_{4}{ }^{-2}$ increased by several fold. Nitrate concentrations showed the greatest increases, rising from an average of about 1.7 to $4.7 \mathrm{ppm}-\mathrm{N}$ on reference sites to an average of 47 to $66 \mathrm{ppm}-\mathrm{N}$ on application sites. Metals and radionuclides were not elevated in soil water on sludge application sites.

Five groundwater wells (three downgradient of the application site) were used to evaluate the potential impacts of sludge application on ground water quality. Two of the downgradient wells were located on the edge of the sludge application site. The third was located about 50 to $100 \mathrm{~m}$ further downgradient. The downgradient wells were quite shallow (20 to $30 \mathrm{ft}$ ) and sampled water at the top of the groundwater table at the portion of the application site with the lowest elevation. These wells responded rapidly to rainfall and were in close communication with local groundwater. One of the downgradient wells on the edge of the sludge field showed increased concentrations of $\mathrm{NO}_{3}^{-}$(up to $6 \mathrm{ppm}-\mathrm{N}$ ) and fecal coliform (up to 9800 colonies $/ 100 \mathrm{ml}$ ). No other constituents were above reference levels in this or the other downgradient wells. The well showing the increased $\mathrm{NO}_{3}{ }^{-}$and fecal coliform could be considered a worst possible case for potential groundwater contamination based upon its shallow depth and location. Overall, the groundwater data indicated the potential for groundwater contamination from sludge application is similar to that expected from the application of manure or chemical fertilizers.

Samples of surface runoff were collected on sludge fields and in tributaries downgradient of sludge application sites during and following sludge application. Grab or flow proportional composite samples from the application sites were compared with samples from upstream or 
reference areas. Conductivity, biological oxygen demand, fecal coliform, $\mathrm{N0}_{3}^{-}$, and soluble phosphorus were consistently elevated as a result of sludge application. Other parameters (metals, etc.) were not elevated in runoff from sludge sites. Application to pasture sites, where the soil surface was disturbed, resulted in more surface runoff and runoff of poorer quality compared with sludge applications to tree plantations or forested sites, where the ground surface was not disturbed. The quality of surface runoff from pasture application sites was similar to that expected from pastures with grazing animals.

Vegetation (grass, pine needles, weeds, and blackberries) samples were collected following sludge application to evaluate the movement of sludge constituents into the vegetation and the potential for transfer to animals. During sludge application, the vegetation concentrations of $\mathrm{N}, \mathrm{P}, \mathrm{K}, \mathrm{Ca}, \mathrm{Mg}, \mathrm{Fe}, \mathrm{Ag}, \mathrm{Cu}, \mathrm{Na}, \mathrm{Pb}$, and $\mathrm{Zn}$ were higher than concentrations on the reference sites, mainly because of surface contamination with sludge. Following sludge application, plant concentrations of $\mathrm{N}, \mathrm{P}, \mathrm{Ca}, \mathrm{S}, \mathrm{Mg}, \mathrm{Fe}, \mathrm{Zn}$, and $\mathrm{Al}$ remained higher on the application sites than on adjacent reference sites. Radionuclide concentrations in vegetation may have been slightly elevated; however, concentrations were consistently close to method detection limits. Concentrations of sludge-added radionuclides in vegetation were orders of magnitude lower than concentrations of naturally occurring radionuclides $\left({ }^{40} \mathrm{~K}\right.$ and $\left.{ }^{7} \mathrm{Be}\right)$ in those plants.

The information collected to date demonstrates that application of municipal sewage sludge from the City of Oak Ridge on the DOE ORR has not resulted in any significant impacts on environmental quality or future uses of the application sites. Radionuclides and metals in the sludge are quantitatively retained in the upper $15 \mathrm{~cm}$ of soil and are not found in soil water, groundwater, or surface runoff. Some constituents [nutrients, fecal coliform, biological oxygen demand (BOD)] in runoff from sludge sites have the potential to degrade the quality of nearby surface water; therefore, care should be taken to avoid sludge application in areas near surface water. To minimize the potential for poor quality surface runoff from sludge application sites, sludge should be applied at rates that avoid sludge buildup on soil surfaces; appropriate buffer strips between application sites and surface water resources should be provided; and, to minimize disturbance of the soil, the sludge should be sprayed over the surface rather than injected. The potential for groundwater contamination can be minimized by avoidance of sludge application in areas with sinkholes or active groundwater wells and by compliance with prescribed annual nitrogen-loading rates.

Land application of municipal sewage sludge can dilute or destroy problematic sludge constituents while improving soil fertility on application sites. Sludge application must be managed to avoid impacts to human health and the environment. Responsible behavior by the DOE Oak Ridge Operations Office and the City of Oak Ridge have made these sludge applications a model of environmentally responsible waste management. 


\section{INTRODUCTION: HISTORY OF SLUDGE APPLICATION AND MONITORING ON THE OAK RIDGE RESERVATION}

Oak Ridge municipal sewage sludge has been applied on the U.S.Department of Energy (DOE) Oak Ridge Reservation (ORR) lands since 1983, both as a disposal method for the city and as a beneficial amendment to the soil which could increase tree growth. Late in 1986, researchers in Oak Ridge National Laboratory's (ORNL) Environmental Sciences Division (ESD) became involved in the project, and environmental monitoring was initiated in early 1987 as part of the Sludge Land-Farming Research and Demonstration Project.

From 1986 through 1993, anaerobically digested sludge from the City of Oak Ridge Wastewater Treatment Plant was applied to a series of grassy fields and forested sites on the ORR. The sludge, typically between 2 and $4 \%$ solids, was applied by spraying or by subsurface injection as often as daily, when weather and equipment permitted. Individual application sites are described in Sect. 3.

The formal monitoring program has varied in scope and intensity as specific questions have arisen and been adequately answered. The parameters that have been monitored during various stages of the program include metals, plant nutrients, radionuclides, water chemistry, nitrogen, organics, and coliform bacteria. These parameters were monitored in the sludge itself and in soils, vegetation, soil water, groundwater, and surface runoff. Specifics of the monitoring program are discussed in Sect. 3 and in sections on the individual environmental media monitored. 


\section{SLUDGE CHARACTERISTICS}

\section{SAMPLING: PARAMETERS OF INTEREST AND METHODS}

Treatment of Oak Ridge municipal sludge includes both primary and secondary processes. Sewage passes through (1) a primary sedimentation and clarification process and (2) a settled, activated sludge process. Sludge from these units is then pumped to two anaerobic digesters maintained at $35^{\circ} \mathrm{C}$ with an average 30 -d detention time. The sludge is then transferred to a secondary digester with a 30-d detention time, for an approximate total detention time of $50-60 \mathrm{~d}$. The anaerobic digesters constitute a "process to significantly reduce pathogens" (PSRP). The sludge then passes to a final holding tank, called a storage digester, and from there is loaded into a 5400-gal tank truck, which is used to deliver sludge from the sewage treatment plant to the application site. At the application site, sludge is transferred to a smaller application vehicle holding approximately 1500 gal. As many as 6 tank truckloads may be applied in a single day if weather and staffing permit.

During much of the period covered by this report, samples were taken from each tankload of sludge as it left the treatment plant and were saved for a weekly composite sample that was analyzed for radionuclides at ORNL ESD by gamma ray spectrometry with high purity intrinsic germanium detectors. The details of these radionuclide analyses are given in Appendix A.

A monthly composite sample was sent to A\&L Laboratories in Memphis, Tennessee, for analysis of nutrients and metals by wet chemistry, inductively coupled plasma spectrometry (ICP), and atomic absorption (AA). Twice a year, Eckenfelder, Inc., of Nashville, Tennessee, measured organics (volatiles, semivolatiles, and pesticides) according to EPA methods. Total uranium in dried sludge was determined (monthly, starting in 1989) by the neutron activation method [(Oak Ridge Associated Universities (ORAU)]. For reference only, neutron activation data are also provided for a few metals ( $\mathrm{Fe}, \mathrm{Ag}, \mathrm{Ba}, \mathrm{Co}$, and $\mathrm{Mn}$ ) for which no data from the A\&L analysis were available. ${ }^{90} \mathrm{Sr}$ and ${ }^{99} \mathrm{Tc}$ were also determined on a few samples by the ORNL Analytical Chemistry Division.

\subsection{VARIATION IN SLUDGE CHARACTERISTICS OVER TIME}

Table 2.1 shows average annual concentrations of various nutrients and heavy metals in the sludge from 1988 to 1993 , along with the number of monthly composite samples contributing to the mean. Data are on a dry weight basis, and total percent solids in the liquid sludge is also shown. Table 2.2 contains limited data on metals from the earlier years, 1984 through 1986, along with the number of weekly samples used to compute the mean. Concentrations of several of the constituents, including the major plant nutrients, have remained fairly constant over the years 1984-1993, but the concentrations of several metals of concern (e.g., $\mathrm{Cr}, \mathrm{Cu}, \mathrm{Ni}, \mathrm{Pb}$, and $\mathrm{Zn}$ ) have decreased markedly during this period. Concentrations of uranium were particularly high in $1988(165 \mathrm{mg} / \mathrm{kg}, \mathrm{n}=1)$ and 1989 (85 $\pm 25 \mathrm{mg} / \mathrm{kg}$ ), but decreased to $33.9 \pm 4.2 \mathrm{in} 1991$ and $31.9 \pm 1.5 \mathrm{mg} / \mathrm{kg}$ in 1992 (Table 2.1). 
Table 2.1. Yearly average concentrations of nutrients and metals in Oak Ridge sewage sludge, 1988-1993

\begin{tabular}{|c|c|c|c|c|c|c|c|c|c|c|c|c|c|}
\hline & & $\begin{array}{r}1988 \\
\text { Mean }\end{array}$ & $\begin{array}{r}1988 \\
n\end{array}$ & $\begin{array}{r}1989 \\
\text { Mean }\end{array}$ & $\begin{array}{r}1989 \\
\mathrm{n}\end{array}$ & $\begin{array}{r}1990 \\
\text { Mean }\end{array}$ & $\begin{array}{r}1990 \\
\text { Std }\end{array}$ & $\begin{array}{r}1991 \\
\text { Mean }\end{array}$ & $\begin{array}{r}1991 \\
\text { Std }\end{array}$ & $\begin{array}{r}1992 \\
\text { Mean }\end{array}$ & $\begin{array}{r}1992 \\
\text { Std }\end{array}$ & $\begin{array}{r}1993 \\
\text { Mean }\end{array}$ & $\begin{array}{r}1993 \\
\text { Std }\end{array}$ \\
\hline Solids & $\%$ & 2.13 & 3 & 2.53 & 11 & 2.63 & 1.02 & 2.47 & 0.27 & 2.64 & 0.38 & 2.78 & 0.32 \\
\hline Kjeldahl N & $\%$ & 9.19 & 4 & 8.07 & 11 & 7.84 & 0.56 & 8.26 & 1.87 & 7.74 & 0.68 & 7.18 & 0.92 \\
\hline $\mathrm{NH}_{4} \mathrm{~N}$ & $\%$ & & 0 & 3.70 & 11 & 3.71 & 0.44 & 3.18 & 0.32 & 3.09 & 0.41 & 3.15 & 0.96 \\
\hline $\mathbf{P}$ & $\%$ & 2.87 & 6 & 2.77 & 11 & 2.84 & 0.43 & 2.97 & 0.23 & 2.96 & 0.35 & 3.18 & 0.39 \\
\hline K & $\%$ & 0.66 & 5 & 0.64 & 12 & 0.42 & 0.17 & 0.47 & 0.17 & 0.42 & 0.10 & 0.45 & 0.07 \\
\hline $\mathrm{Fe}$ & $\%$ & 1.90 & 2 & 1.85 & 12 & 1.90 & 0.39 & 1.83 & 0.15 & 1.50 & 0.24 & & \\
\hline $\mathrm{Ca}$ & $\%$ & 3.70 & 4 & 3.64 & 11 & 4.02 & 3.48 & 4.04 & 0.90 & 4.09 & 1.81 & 3.42 & 0.31 \\
\hline $\mathrm{Mg}$ & $\%$ & 0.60 & 4 & 0.49 & 12 & 0.44 & 0.11 & 0.50 & 0.04 & 0.44 & 0.06 & 0.45 & 0.05 \\
\hline $\mathrm{Na}$ & $\%$ & 0.21 & 2 & 0.16 & 12 & 0.30 & 0.33 & 0.39 & 0.20 & 0.25 & 0.09 & 0.29 & 0.13 \\
\hline $\mathrm{NO}_{3} \mathrm{~N}$ & $\mathrm{mg} / \mathrm{kg}$ & & 0 & 13.6 & 9 & 117.5 & 176 & 9.8 & 7.8 & 14.5 & 7.0 & 19.3 & 9.4 \\
\hline $\mathrm{Ag}$ & $\mathrm{mg} / \mathrm{kg}$ & 123.3 & 3 & 111.0 & 12 & 115.2 & 11.7 & 111.0 & 8.3 & 108.2 & 3.6 & & \\
\hline As & $\mathrm{mg} / \mathrm{kg}$ & 5.60 & 1 & 4.49 & 12 & 6.06 & 5.79 & 4.05 & 0.69 & 3.44 & 0.79 & 5.90 & 5.86 \\
\hline $\mathbf{B a}$ & $\mathrm{mg} / \mathrm{kg}$ & 790 & 3 & 728 & 12 & 933 & 134 & 1012 & 93 & 861 & 93 & & \\
\hline $\mathrm{Cd}$ & $\mathrm{mg} / \mathrm{kg}$ & 9.92 & 6 & 6.75 & 11 & 8.93 & 3.22 & 7.94 & 2.75 & 11.65 & 3.65 & 10.37 & 1.65 \\
\hline Co & $\mathrm{mg} / \mathrm{kg}$ & 17.00 & 1 & 11.23 & 12 & 18.42 & 6.15 & 25.20 & 5.83 & 9.76 & 3.09 & & \\
\hline $\mathrm{Cr}$ & $\mathrm{mg} / \mathrm{kg}$ & 215.8 & 6 & 174.0 & 12 & 152.7 & 71.2 & 138.6 & 33.5 & 160.3 & 58.6 & 153.6 & 28.7 \\
\hline $\mathrm{Cu}$ & $\mathrm{mg} / \mathrm{kg}$ & 576.7 & 6 & 495.5 & 12 & 482.3 & 65.7 & 478.8 & 24.5 & 472.9 & 77.4 & 460.8 & 83.2 \\
\hline $\mathrm{Hg}$ & $\mathrm{mg} / \mathrm{kg}$ & 16.00 & 2 & 9.00 & 12 & 9.67 & 5.06 & 14.54 & 3.89 & 8.58 & 2.74 & 9.13 & 3.01 \\
\hline Mn & $\mathrm{mg} / \mathrm{kg}$ & 667 & 4 & 1930 & 12 & 1490 & 538 & 1669 & 158 & 1174 & 523 & 1269 & $(m-2)$ \\
\hline Mo & $\mathrm{mg} / \mathrm{kg}$ & 60.0 & 1 & 18.0 & 11 & 28.3 & 14.4 & 25.2 & 9.4 & 24.4 & 4.8 & 27.1 & 4.08 \\
\hline $\mathrm{Ni}$ & $\mathrm{mg} / \mathrm{kg}$ & 66.0 & 6 & 40.1 & 11 & 50.7 & 14.8 & 41.6 & 7.5 & 37.3 & 7.6 & 40.2 & 5.3 \\
\hline $\mathbf{P b}$ & $\mathrm{mg} / \mathrm{kg}$ & 167.5 & 6 & 116.0 & 11 & 80.7 & 12.5 & 85.8 & 12.5 & 80.2 & 28.4 & 69.3 & 17.0 \\
\hline $\mathrm{Se}$ & $\mathrm{mg} / \mathrm{kg}$ & & 0 & 6.96 & 10 & 5.70 & 1.14 & 7.69 & 2.45 & 6.68 & 1.25 & 7.61 & 4.12 \\
\hline $\mathrm{U}^{a}$ & $\mathrm{mg} / \mathrm{kg}$ & 165.0 & 1 & 85.4 & 12 & 40.5 & 8.8 & 33.9 & 4.2 & 31.5 & 1.1 & & \\
\hline $\mathrm{Zn}$ & $\mathrm{mg} / \mathrm{kg}$ & 2001 & 6 & 1703 & 12 & 1771 & 310 & 1731 & 334 & 1649 & 240 & 1698 & 188 \\
\hline
\end{tabular}

NOTE: Data from A\&L Laboratories and ORAU (see text). Concentrations are in \% or mg/kg as indicated, on a dry weight basis. The number of monthly samples contributing to each mean is given by $n$ for 1988 and 1989. For 1990-1993, 12 samples contributed to each mean except as indicated. Instead of $n$., the sample standard deviation (Std) is given for these years. Blank cells indicate that no data are available. 
Table 22. Mean concentrations of metals in Oak Ridge sewage sludge, 1984-1986

\begin{tabular}{|c|c|c|c|c|c|c|c|}
\hline & & \multicolumn{2}{|c|}{1984} & \multicolumn{2}{|c|}{1985} & \multicolumn{2}{|c|}{1986} \\
\hline & & Mean & $\mathbf{n}$ & Mean & $\mathbf{n}$ & Mean & $\mathbf{n}$ \\
\hline Total solids & $\%$ & 3.66 & 47 & 2.93 & 47 & 2.84 & 15 \\
\hline Kjeldahl N & $\%$ & & & & & & \\
\hline NH4 N & $\%$ & & & & & & \\
\hline $\mathbf{P}$ & $\%$ & & & & & & \\
\hline $\mathrm{K}$ & $\%$ & & & & & & \\
\hline $\mathrm{Fe}$ & $\%$ & & & & & & \\
\hline $\mathrm{Ca}$ & $\%$ & & & & & & \\
\hline $\mathrm{Mg}$ & $\%$ & & & & & & \\
\hline $\mathrm{Na}$ & $\%$ & & & & & & \\
\hline NO3 N & $\mathrm{mg} / \mathrm{kg}$ & & & & & & \\
\hline $\mathrm{Ag}$ & $\mathrm{mg} / \mathrm{kg}$ & & & 114 & 3 & 104 & 4 \\
\hline As & $\mathrm{mg} / \mathrm{kg}$ & & & 14 & 3 & 4.5 & 4 \\
\hline $\mathrm{Ba}$ & $\mathrm{mg} / \mathrm{kg}$ & & & 1090 & 3 & 840 & 4 \\
\hline $\mathrm{Cd}$ & $\mathrm{mg} / \mathrm{kg}$ & 18 & 47 & 13 & 46 & 11 & 17 \\
\hline Co & $\mathrm{mg} / \mathrm{kg}$ & & & & & & \\
\hline $\mathrm{Cr}$ & $\mathrm{mg} / \mathrm{kg}$ & 843 & 46 & 546 & 47 & 501 & 17 \\
\hline $\mathrm{Cu}$ & $\mathrm{mg} / \mathrm{kg}$ & 1818 & 47 & 835 & 47 & 797 & 17 \\
\hline $\mathrm{Hg}$ & $\mathrm{mg} / \mathrm{kg}$ & & & 11 & 3 & 19.5 & 4 \\
\hline Mn & $\mathrm{mg} / \mathrm{kg}$ & · & & $\cdot$ & & & \\
\hline Mo & $\mathrm{mg} / \mathrm{kg}$ & & & & & & \\
\hline $\mathrm{Ni}$ & $\mathrm{mg} / \mathrm{kg}$ & 203 & 47 & 112 & 46 & 114 & 16 \\
\hline $\mathrm{Pb}$ & $\mathrm{mg} / \mathrm{kg}$ & 198 & 47 & 229 & 47 & 233 & 16 \\
\hline $\mathrm{Se}$ & $\mathrm{mg} / \mathrm{kg}$ & & & $<7$ & 3 & 6.7 & 4 \\
\hline $\mathrm{U}$ & $\mathrm{mg} / \mathrm{kg}$ & & & 35 & 3 & 59 & 4 \\
\hline $\mathrm{Zn}$ & $\mathrm{mg} / \mathrm{kg}$ & 3138 & 47 & 2679 & 47 & 2336 & 17 \\
\hline
\end{tabular}

Means are based on analyses of $n$ weekly samples. Metal concentrations are in $\mathrm{mg} / \mathrm{kg}$ on a dry weight basis; total solids is as a percent. Source: Boston, H. L. 1988.

Environmental Evaluation for the McCoy Sludge Application Site. 
Some radionuclides that may be at least partially attributed to industrial or medical origins were routinely detected in sludge by gamma emission spectrometry. These were ${ }^{60} \mathrm{Co},{ }^{137} \mathrm{Cs}$, and ${ }^{131} \mathrm{I}$. In addition, ${ }^{238} \mathrm{U}$, an indicator of total $\mathrm{U}$, was present above detection limits in some samples. A summary of the radionuclide analyses (in the form of mean annual concentrations) for 1988 through 1992 is provided in Tables $2.3 \mathrm{a}$ and 2.3b. In addition, Appendix B contains the radionuclide data from each weekly composite sample analyzed during this period. Standard deviations for the means in Table 2.3 tend to be high because the concentrations may vary from below detection limits one week to very high concentrations the next as a pulse of the radionuclide travels through the treatment system (see Appendix B). Sludge concentrations of these radionuclides, plus naturally occurring and atmospherically deposited radionuclides (for 1990) may also be found in Larsen, et al., (1992). Total Sr (essentially ${ }^{90} \mathrm{Sr}$ ), analyzed in four of the weekly sludge samples collected in 1992 was $5.0 \pm 8.9,1.6 \pm 7.6,13.0 \pm 10$, and $12.0 \pm 10 \mathrm{~Bq} / \mathrm{kg}$ for samples from February 1992, March 1993, June 1992, and September 1992, respectively. Levels of ${ }^{99} \mathrm{Tc}$ in the February 1992 and September 1992 samples were $13.0 \pm 13$ and $0 \pm$ 11. $\mathrm{Bq} / \mathrm{Kg}$, respectively.

The concentrations of regulated organics and pesticides in Oak Ridge sludge have generally been below analytical detection limits. See the Annual Reports for the City of Oak Ridge. Wastewater Treatment Plant's Biosolids Management for specific analyses. For example, in 1992, analyses from Eckenfelder, Inc., as reported in the 1992 Annual Report, listed six estimated concentrations of organics, three of which were between the method detection limit (MDL) and the practical quantitation limit, and three of which were actually below the listed MDL.

\section{COMPARISON WITH OTHER MUNICIPAL SLUDGES}

Municipal sludges can generally be divided into sludges that are suitable for land application and sludges that are much higher in concentrations of heavy metals (e.g., Cd and $\mathrm{Pb}$ ) or organics and are disposed of by landfilling or incineration. Table 2.4 shows the 5-year average (1988-1992) concentrations of selected constituents of Oak Ridge sludge in comparison with their concentrations in other municipal sludges that were land-applied (for purposes of fertilization, soil conditioning, and reclamation, Mumma, et al., 1984). These sludge samples were from Baltimore, Maryland, (land reclamation, compost, landfill); Knoxville, Tennessee, (landfill); Lexington, Kentucky, (fertilizer and soil conditioner for farmland); Philadelphia, Pennsylvania, (land applied, land reclamation); Portland, Oregon, (land disposal and reclamation); and Salt Lake City, Utah, (park and farmland application). Data for these other municipalities were taken from Mumma, et al., 1984, and represent the analysis of a single sample from each treatment plant. In comparison with these sludges, the concentrations of $\mathrm{N}, \mathrm{P}, \mathrm{K}, \mathrm{Fe}, \mathrm{Ca}$, and $\mathrm{Mg}$ (major and minor plant nutrients) were above or near the high end of the ranges shown in Table 2.4; whereas, the concentrations of other metals, except $\mathrm{Mn}$ and $\mathrm{U}$, were generally within the concentration range of sludges from other cities, or substantially lower. Uranium concentrations were higher in Oak Ridge sludge than in other sludges, but concentrations have been decreasing since 1988 (Tables 2.2 and 2.3). Concentrations of $\mathrm{Cd}$ and $\mathrm{Cr}$ in Oak Ridge sludge are at the low end of the range shown in Table 2.4, and $\mathrm{Ni}$ and $\mathrm{Pb}$ concentrations are lower in Oak Ridge sludge than in sludges from other cities cited in Table 2.4 . 
Table 23(a). Yearly average concentrations of radionuclides in Oak Ridge sewage sludge, mid-1988 through 1992. (Annual statistics are mean ( \pm standard deviation where available) of the 52 weekly samples, except where noted.

Concentrations are in $\mathrm{pCi} / \mathrm{g}$ dry weight.

\begin{tabular}{|c|c|c|c|c|c|c|c|c|c|c|}
\hline \multirow[b]{3}{*}{${ }^{60} \mathrm{Co}$} & \multicolumn{2}{|c|}{1988} & \multicolumn{2}{|c|}{1989} & \multicolumn{2}{|c|}{1990} & \multicolumn{2}{|c|}{1991} & \multicolumn{2}{|l|}{1992} \\
\hline & Mean & $\mathrm{n}$ & Mean & & Mean & & Mean & & Mean & \\
\hline & 5.92 & $\begin{array}{l}3 \\
2\end{array}$ & 2.57 & 52 & $\begin{array}{r}3.19 \\
( \pm 2.7)\end{array}$ & 50 & $\begin{array}{r}1.02 \\
( \pm 0.7)\end{array}$ & 52 & $\begin{array}{c}0.71 \\
( \pm 0.53)\end{array}$ & 52 \\
\hline${ }^{137} \mathrm{Cs}$ & 1.17 & $\begin{array}{l}3 \\
2\end{array}$ & 1.23 & 52 & $\begin{array}{r}2.49 \\
( \pm 3.3)\end{array}$ & 50 & $\begin{array}{r}1.38 \\
( \pm 1.0)\end{array}$ & 52 & $\begin{array}{c}0.48 \\
( \pm 0.21)\end{array}$ & 52 \\
\hline${ }^{131}$ I & 7.09 & $\begin{array}{l}3 \\
2\end{array}$ & 9.17 & 52 & $\begin{array}{r}5.42 \\
( \pm 7.9)\end{array}$ & 50 & $\begin{array}{c}9.55 \\
( \pm 19)\end{array}$ & 52 & $\begin{array}{r}13.9 \\
( \pm 18.7)\end{array}$ & 52 \\
\hline${ }^{238} \mathrm{U}$ & 81.5 & $\begin{array}{l}3 \\
1\end{array}$ & 20.0 & $52^{a}$ & $\begin{array}{r}6.01 \\
( \pm 15.5)\end{array}$ & $50^{b}$ & $\begin{array}{c}4.94 \\
( \pm 155)\end{array}$ & $52^{c}$ & 3.31 & $18^{d}$ \\
\hline
\end{tabular}

${ }^{a}$ Fifteen values below minimum detection limit were treated as zeroes.

${ }^{b}$ Thirty-five values below minimum detection limit were treated as zeroes.

'Six values below minimum detection limit were treated as zeroes.

Tour values below minimum detection limit were treated as zeroes.

NOTE: A sample of sludge was taken from each truckload as it left the treatment plant, and these samples were composited and analyzed weekly. Values for ${ }^{238} U$ were often below the detection limit after 1988 , but were quite variable. Analyses were done at Oak Ridge National Laboratory (Environmental Sciences Division) by gamma emission spectrometry. Weekly values contributing to these means are shown in AppendixB.

Table 23(b). Yearly average concentrations of radionuclides in Oak Ridge sewage sludge, mid-1988 through 1992 (Means as in Table 2.3(a), but in Bq/g dry weight.)

\begin{tabular}{lccccc}
\hline & 1988 & 1989 & 1990 & 1991 & 1992 \\
\hline${ }^{60} \mathrm{Co}$ & 0.22 & 0.10 & 0.12 & 0.04 & 0.03 \\
${ }^{137} \mathrm{Cs}$ & 0.04 & 0.05 & $0.09)$ & 0.05 & 0.02 \\
${ }^{131} \mathrm{I}$ & 0.26 & 0.34 & 0.20 & 0.35 & 0.51 \\
${ }^{238} \mathrm{U}$ & 3.02 & 0.73 & 0.22 & 0.18 & 0.12 \\
\hline
\end{tabular}


Table 2.4. Comparison of concentrations of various elements in Oak Ridge sewage sludge with those in other municipal sewage sludges used for land application, land reclamation, fertilizer-soil conditioning, and park and farmland application

\begin{tabular}{|c|c|c|c|c|c|c|c|c|}
\hline & & Oak Ridge & Baltimore & Knauville & Lexington & Philadelphia & Portland & Salt Lake City \\
\hline $\mathrm{N}^{a}$ & $\%$ & 8.08 & 3.7 & 2.2 & 2.4 & 0.6 & 1.5 & $\overline{2.1}$ \\
\hline $\mathbf{P}$ & $\%$ & 2.88 & 1.6 & 0.74 & 2.8 & 0.72 & 0.98 & 2.6 \\
\hline $\mathbf{K}$ & $\%$ & 0.50 & 0.01 & 0.05 & 0.05 & 0.06 & 0.09 & 0.10 \\
\hline $\mathrm{Fe}$ & $\%$ & 1.81 & 1.8 & 3.0 & 1.8 & 1.9 & 2.4 & 1.2 \\
\hline $\mathrm{Ca}$ & $\%$ & 3.95 & 2.1 & 1.0 & 4.4 & 2.7 & 1.5 & 6.9 \\
\hline Mg & $\%$ & 0.48 & 0.2 & 0.15 & 0.36 & 1.3 & 0.21 & 0.55 \\
\hline $\mathrm{Na}$ & $\%$ & 0.27 & 0.13 & 0.15 & 0.12 & 0.2 & 1.2 & 0.35 \\
\hline As & $\mathrm{mg} / \mathrm{kg}$ & 4.56 & 6.0 & 5.0 & 2.4 & 7.1 & 3.3 & 25 \\
\hline $\mathrm{Ba}$ & $\mathrm{mg} / \mathrm{kg}$ & 881 & 1258 & 462 & 607 & 52.4 & 372 & 3703 \\
\hline $\mathrm{Cd}$ & $\mathrm{mg} / \mathrm{kg}$ & 8.96 & 19.5 & 7.5 & 22.9 & 12.0 & 31 & 37 \\
\hline Co & $\mathrm{mg} / \mathrm{kg}$ & 17.1 & 13.2 & 7.2 & 4.3 & 8.2 & 21.6 & 11.9 \\
\hline $\mathrm{Cr}$ & $\mathrm{mg} / \mathrm{kg}$ & 162.7 & 3087 & 1279 & 186 & 1290 & 572 & 2450 \\
\hline $\mathrm{Cu}$ & $\mathrm{mg} / \mathrm{kg}$ & 493.8 & 7729 & 309 & 7575 & 907 & 398 & 4307 \\
\hline $\mathbf{H g}$ & $\mathrm{mg} / \mathrm{kg}$ & 10.7 & 12.4 & 8.1 & 6.9 & 3.0 & 4.8 & 12.1 \\
\hline Mn & $\mathrm{mg} / \mathrm{kg}$ & 1539 & 121 & 233 & 230 & 529 & 277 & 141 \\
\hline Mo & $\mathrm{mg} / \mathrm{kg}$ & 24.9 & 22.5 & 10.7 & 19.5 & 10.3 & 21.9 & 30.4 \\
\hline $\mathrm{Ni}$ & $\mathrm{mg} / \mathrm{kg}$ & 45.4 & 420 & 105 & 68.0 & 305 & 215 & 400 \\
\hline $\mathrm{Pb}$ & $\mathrm{mg} / \mathrm{kg}$ & 99.4 & 160 & 258 & 206 & 475 & 282 & 330 \\
\hline $\mathrm{Sc}$ & $\mathrm{mg} / \mathrm{kg}$ & 6.75 & 13.0 & 2.7 & 6.7 & 1.0 & 2.1 & 6.7 \\
\hline $\mathbf{U}$ & $\mathrm{mg} / \mathrm{kg}$ & 52.8 & 6.5 & 1.7 & 2.3 & 3.6 & 2.3 & 5.4 \\
\hline $\mathrm{Zn}$ & $\mathrm{mg} / \mathrm{kg}$ & 1746 & 4500 & 1100 & 1688 & 863 & 1813 & 1975 \\
\hline
\end{tabular}

${ }^{a}$ All nitrogen values measured by the Kjehldahl method.

NOTE: Oak Ridge data represents the 5-year average (from 1988-1982) of monthly samples $(n=43-53)$. Data for other municipal sludges represents analysis of a single sample as published in Mumma, et al., (1984). Concentrations units are $\% \mathrm{or} \mathrm{mg} / \mathrm{kg}$ on a dry weight basis. 
Radionuclide concentrations in other municipal sludges are not generally available, but have been determined locally. Data for radionuclide analysis of other sludge samples collected by E. A Stetar from treatment plants in this region are given in Table 2.5. Samples were counted in 1-L Marinelli beakers overnight at ORNL ESD (methods, Appendix A). These data can be compared to the means in Table 2.3(b) and to the weekly data in Appendix B. Levels of ${ }^{131} \mathrm{I},{ }^{137} \mathrm{CS},{ }^{7} \mathrm{Be},{ }^{40} \mathrm{~K}$, and ${ }^{228} \mathrm{Ra}$ in Oak Ridge sludge were comparable to levels in regional samples (sometimes higher, sometimes lower). No ${ }^{60} \mathrm{Co}$ or uranium were detected in the regional samples outside of Oak Ridge (Table 2.5).

Table 2.5. Radionuclides in regional wastewater treatment plant sludges

\begin{tabular}{|c|c|c|c|c|c|c|}
\hline Location & Date & ${ }^{131} I$ & ${ }^{177} \mathrm{Cs}$ & ${ }^{7} \mathrm{Be}$ & \multicolumn{2}{|c|}{${ }^{40} \mathrm{~K}{ }^{228} \mathrm{Ra}$} \\
\hline $\operatorname{Dup}^{a}$ & $8 / 19 / 92$ & $\begin{array}{l}34.7 \\
37.8\end{array}$ & $\begin{array}{l}0.10 \\
0.14\end{array}$ & $\begin{array}{l}2.05 \\
2.79\end{array}$ & $\begin{array}{l}11.5 \\
11.1\end{array}$ & $\begin{array}{l}1.05 \\
1.32\end{array}$ \\
\hline $\operatorname{Dup}^{b}$ & $8 / 19 / 92$ & $\begin{array}{l}0.18 \\
0.13\end{array}$ & $\begin{array}{l}0.10 \\
0.05\end{array}$ & $\begin{array}{l}2.47 \\
2.27\end{array}$ & $\begin{array}{l}\text { N.D. } \\
2.07\end{array}$ & $\begin{array}{l}0.89 \\
0.45\end{array}$ \\
\hline Dup $^{c}$ & $8 / 20 / 92$ & $\begin{array}{l}2.82 \\
3.16\end{array}$ & $\begin{array}{r}0.05 \\
\text { N.D. }\end{array}$ & $\begin{array}{l}0.96 \\
0.81\end{array}$ & $\begin{array}{c}\text { N.D. } \\
0.41\end{array}$ & $\begin{array}{l}0.28 \\
0.21\end{array}$ \\
\hline $\operatorname{Dup}^{d}$ & $8 / 20 / 92$ & $\begin{array}{l}0.72 \\
0.88\end{array}$ & $\begin{array}{l}0.10 \\
0.23\end{array}$ & $\begin{array}{l}0.98 \\
1.12\end{array}$ & $\begin{array}{l}4.96 \\
6.40\end{array}$ & $\begin{array}{l}0.96 \\
1.28\end{array}$ \\
\hline Dup $^{e}$ & $8 / 20 / 92$ & $\begin{array}{l}2.38 \\
2.50\end{array}$ & $\begin{array}{l}\text { N.D. } \\
\text { N.D. }\end{array}$ & $\begin{array}{l}1.56 \\
1.52\end{array}$ & $\begin{array}{l}1.13 \\
2.0\end{array}$ & $\begin{array}{l}0.63 \\
0.59\end{array}$ \\
\hline $\operatorname{Dup}^{f}$ & $8 / 19 / 92$ & 2.03 & 0.05 & 1.35 & 3.0 & 0.23 \\
\hline $\begin{array}{r}{ }^{a} \mathrm{Kno} \\
{ }^{b} \text { Lenc } \\
{ }^{a} \mathrm{Mor} \\
{ }^{d} \text { Sevi } \\
{ }^{e} \text { Sevie } \\
f_{\text {Mary }} \\
\text { NOT } \\
1 \mathrm{~kg} \mathrm{(1} \mathrm{L)} \\
\text { by E. A St }\end{array}$ & $\begin{array}{l}\text { Tennesse } \\
y, \text { Tenne } \\
\text { n, Tenne } \\
\text { Tenness } \\
\text { Tenness } \\
\text { Tennesse } \\
\text { o duplica }\end{array}$ & $\begin{array}{l}\text { ed slud } \\
\text { sted slu } \\
\text { sted slu } \\
\text { ted slud } \\
\text { iry slud } \\
\text { y siudg } \\
\text { s were } \\
\text { vernigh }\end{array}$ & $\begin{array}{l}29 \% \text { soli } \\
1.19 \% \\
3.84 \% \text { s } \\
2.48 \% \text { sol } \\
.72 \% \text { soli } \\
\text { D.: Not } \\
\text { n from ea } \\
\text { farinelli b }\end{array}$ & $\begin{array}{l}\text { ed. } \\
\text { atmen } \\
\text { geome }\end{array}$ & aples & $\begin{array}{l}\text { sately } \\
\text { ected }\end{array}$ \\
\hline
\end{tabular}

\subsection{COMPARISON WITH REGULATORY LIMITS}

EPA encourages the reuse of municipal sewage sludges to provide fertilization and soil conditioning to improve marginal lands. They set standards for the use or disposal of sewage sludge under the authority of the Clean Water Act [Title 40, Code of Federal Regulation, Sects. 257, 403, and 503 (40 CFR 257, 403 and 503, including 503.13)] pollutant limits for bulk sewage sludge applied to agricultural, forest, or public lands. Standards include ceiling concentrations, monthly average concentrations and annual and cumulative pollutant loading rates for metals and selected organics. Standards were proposed on February 6, 1989, and were changed and updated on February 19, 1993. The final rule became effective March 22, 1993.

The 1989 proposed rule regulated concentrations of ten metals and twelve organic pollutants only in sludge applied to nonagricultural lands. Sludge application to agricultural 
lands was regulated not in terms of concentration, but in terms of annual and cumulative loading rates. The 1993 final rule, however, includes cumulative pollutant loading rates (Table 2 of 503.13) and monthly average pollutant concentrations (Table 3 of 503.13) for ten metals in sludge applied to agricultural land, forest, public contact sites, or reclamation sites, stating that either the cumulative loading rate shall not exceed the Table 2 standards or that the concentration shall not exceed the Table 3 standards. The final (1993) rule defers promulgating a numerical limit for the organic compounds and pesticides listed in the 1989 proposed rules until more data are available, and there are currently no numerical limits for organics. The City of Oak Ridge National Pollutant Discharge Elimination System permit, although it requires that sludge be tested for several organic compounds, sets no numerical limits for these compounds or for radionuclides. As reported in Sect. 2.2, organic pollutants in Oak Ridge sludge are normally below detection limits.

Table 2.6 compares the concentration of the ten regulated metals in Oak Ridge sludge with the proposed regulatory concentration limits effective during the application period as well as with the new regulations that took effect in 1993. With the exception of molybdenum and mercury, the concentrations of these metals in Oak Ridge sludge (Tables 2.1, 2.6, and 2.2) were well below even the new regulatory limits for monthly average concentrations (Table 3 of 40 CFR 503.13) and far below the new ceiling concentrations in Table 1 of 40 CFR 503.13. Although historical mercury concentrations were close to the new monthly average limit of $17 \mathrm{mg} / \mathrm{kg}$, monthly composite concentrations have not exceeded that value since May 1991, and they never exceeded the 1989 limit of $30 \mathrm{mg} / \mathrm{kg}$ or the 1993 ceiling concentration of $57 \mathrm{mg} / \mathrm{kg}$. Although molybdenum concentrations sometimes exceeded the February 19, 1993, limits of $18 \mathrm{mg} / \mathrm{kg}$, they were always below the 1989 limits of $230 \mathrm{mg} / \mathrm{kg}$ and below the February 19,1993, ceiling concentration of $75 \mathrm{mg} / \mathrm{kg}$. The February 19, 1993, limits could also be satisfied by monitoring the cumulative loading rate of molybdenum. For example, the site with the highest cumulative sludge loading to date has been the Rogers site (48 Mg/ha). Using the 5-year average molybdenum concentration, the cumulative molybdenum loading rate for $48 \mathrm{Mg} /$ ha sludge would be $1.2 \mathrm{~kg} / \mathrm{ha}$ molybdenum-well below the February 19,1993 , regulatory limit of $18 \mathrm{~kg}$ /ha molybdenum. Furthermore, the February 19, 1993, limits for molybdenum, except the ceiling concentration limit of $75 \mathrm{mg} / \mathrm{kg}$, were deleted by amendment of 40 CFR 503 on February 25, 1994, pending reconsideration of appropriate, presumably higher, molybdenum limits. Regulatory limits for loading rates of other metals are addressed further in Sect. 3. 
Table 26. Oak Ridge sludge composition in comparison to pollutant limits from EPA regulations (40 CFR 503) for sludge constituents

\begin{tabular}{|c|c|c|c|c|}
\hline Pollutant & $\begin{array}{l}\text { Oak Ridge Sludge, } \\
\text { 5-year average, } \\
\text { mg/kg }\end{array}$ & $\begin{array}{l}\text { Maximum sludge } \\
\text { concentration for } \\
\text { non-agricultural land } \\
\text { application (mg/kg) } \\
\text { (Proposed limits, } \\
\text { 2/6/89 40 CFR } \\
503.15)^{a}\end{array}$ & $\begin{array}{l}\text { Monthly average } \\
\text { pollutant } \\
\text { concentrations } \\
\text { (agricultural) } \text { (mg/kg) } \\
\text { (Final rule, 2/19/93 } \\
40 \text { CFR 503.13, } \\
\text { Table 3) }\end{array}$ & $\begin{array}{l}\text { Ceiling concentrations } \\
\text { for any land application } \\
\text { (mg/kg) (Final rule, } \\
2 / 19 / 93 \\
40 \text { CFR 503.13, } \\
\text { Table 3) }\end{array}$ \\
\hline Arsenic & 4.56 & 36 & 41 & 75 \\
\hline Cadmium & 8.96 & 380 & 39 & 85 \\
\hline Chromium & 162.7 & 3100 & 1200 & 3000 \\
\hline Copper & 17.1 & 3300 & 1500 & 4300 \\
\hline Lead & 99.4 & 1600 & 300 & 840 \\
\hline Mercury & 10.7 & 30 & 17 & 57 \\
\hline Molybdenum & 24.9 & 230 & $18^{c}$ & 75 \\
\hline Nickel & 45.4 & 990 & 420 & 420 \\
\hline Selenium & 6.75 & 64 & 36 & 100 \\
\hline Zinc & 1746 & 8600 & 2800 & 7500 \\
\hline $\begin{array}{l}{ }^{a} \text { Concen } \\
\text { nitrosamine, } \mathrm{F} \\
\text { and trichloroe } \\
\text { analytical limi } \\
\text { in the Final } \mathrm{R} \\
{ }^{b} \text { For slu } \\
\text { exceeded, or } t \\
\text { of this report } \\
{ }^{\circ} \text { The Fe } \\
\text { deleted by am }\end{array}$ & $\begin{array}{l}\text { tions of Aldrin/dield } \\
\text { tachlor, Hexachlorobe } \\
\text { lene were also propos } \\
\text { Oak Ridge sludge d } \\
\text { issued February } 19,9 \\
\text { applied to agricultura } \\
\text { cumulative loading ra } \\
\text { loading rates. } \\
\text { ary } 19,1993 \text {, limits f } \\
\text { lment of } 40 \text { CFR } 503\end{array}$ & $\begin{array}{l}\text { luring the monitoring } \\
93 \text {. } \\
\text { ll land, forest, or publ } \\
\text { the shall not exceed t1 }\end{array}$ & $\begin{array}{l}\text { ram. Numerical limits } \\
\text { atact site. Either these c } \\
\text { sted in Table } 2 \text { of } 40 \mathrm{C}\end{array}$ & $\begin{array}{l}\text { DD (total), Dimethyl } \\
\text { ed biphenyls, toxaphene, } \\
\text { ally detectable above the } \\
\text { organics were deferred } \\
\text { ncentrations shall not be } \\
\text { R 503.13. See Table } 3.3\end{array}$ \\
\hline
\end{tabular}




\section{SLUDGE APPLICATION: METHODS, APPLICATION SITES, ENVIRONMENTAL MONITORING}

\subsection{SLUDGE APPLICATION}

Anaerobically digested municipal sewage sludge from the City of Oak Ridge Wastewater Treatment Plant was applied to a series of grassy fields and forested sites on the ORR, as described below. This sludge was typically between 2 and $4 \%$ solids and was applied either by surface application (dispensed from jets behind the truck or from a spray gun mounted on top of the delivery vehicle) or by subsurface injection. Photos from this operation appear in Oakes, et al., (1984). Initially, some sites (McCoy site during application, Rogers site after application ended) were tilled periodically to incorporate the sludge into the upper soil horizon. Sludge was applied whenever the weather was favorable, as often as daily during dry periods, although inclement weather, equipment malfunctions, or employee absences could all delay applications. For example, sludge land application occurred on only 196 days in 1991.

Application of sludge shifted from one site to another based on several considerations. Temporary shifts from one field to another occurred frequently because weather conditions resulted in poor traction for the application vehicle or because the annual loading of nitrogen (N) had been reached. On several of these sites, application resumed later in the year, when weather was drier, or 12 months after the allowable loading rate for $\mathrm{N}$ was reached. Other sites were considered permanently closed, either because the planned loading rate for experimental purposes had been achieved (e.g., Sycamore site and Pine site) or, in the case of the $\mathrm{McCl}$ site, because higher than anticipated levels of ${ }^{60} \mathrm{Co}$ and ${ }^{137} \mathrm{CS}$ were applied (Oakes, et al., 1984).

\subsection{APPLICATION SITES}

Individual sites are described below and illustrated in Fig. 3.1, an overview of the ORR with each application site marked. Site numbers on Fig. 3.1 correspond to the original map numbers used by the city and ORNL and are listed with the site descriptions below. Not all original site numbers were actually used, and some sites share a map number. More detailed maps (Figs. 3.2-3.5 indicate such features as sampling wells, positions of flow samplers, and so on. For each site, corresponding reference areas (where sludge was never applied) were available for comparison; these also are noted on the detailed maps. Table 3.1 summarizes some of the application information described below.

\section{Sycamore site (Near number 0 on Fig. 3.1)}

In 1978, a single application of dewatered digested sludge was applied and disked into an approximately 0.5-ha plot off Lewis Road, west of New Zion Patrol Road. This sludge application corresponded to a total $N$ load of $1500 \mathrm{~kg} / \mathrm{ha} \mathrm{N}$ (Van Miegroet, Boston, and Johnson 1989). Following sludge application, a plantation of American sycamore (Platanus occidentalis L.) was established on this site. Data available from this site are limited. 


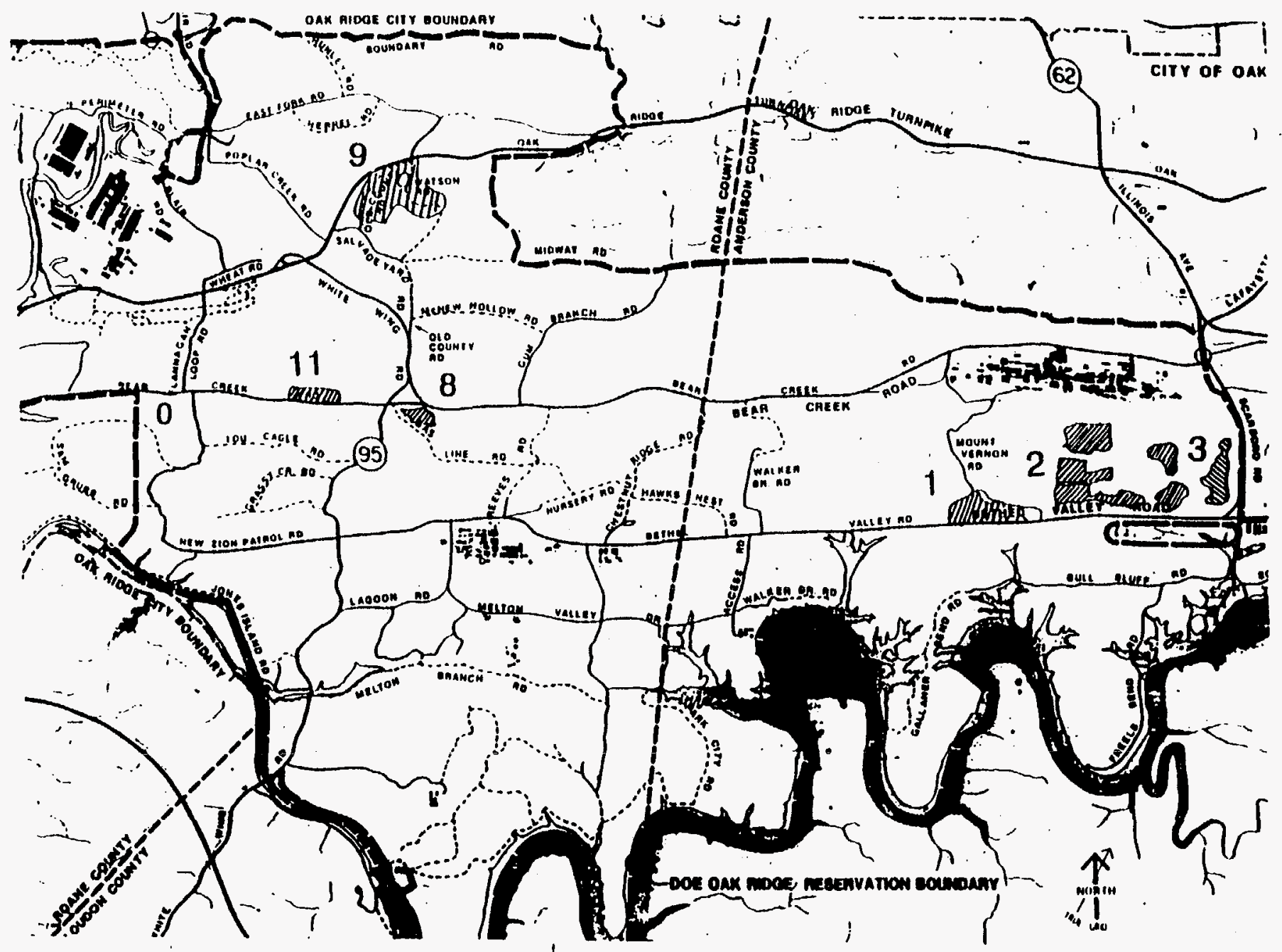

Area designations:

Area $0=$ Sycamore Site

Area $1=$ McCoy Site.

Area 2 = (three application sites). Reading from grid north, it is composed of the Pine Plantation, the High Pasture Site, and the Rogers Site.
Area $3=$ (three application sites). Reading clockwise starting at grid northwest (upper left), it contains the Upper Hayfield Site, the Scarboto Site, and the Upper Hayfield 2 Site. Area $8=$ Site 8 .

Area $9=$ the Watson Road Site.

Area $\mathbf{1 1}=$ the Cottonwood Site

Fig. 3.1. Map of the Oak Ridge Reservation and surrounding area showing the sludge application sites. Numbers correspond to the original numbering scheme used by Dennis Bradburn, Harry Boston, and the City of Oak Ridge to define the sludge application areas. 


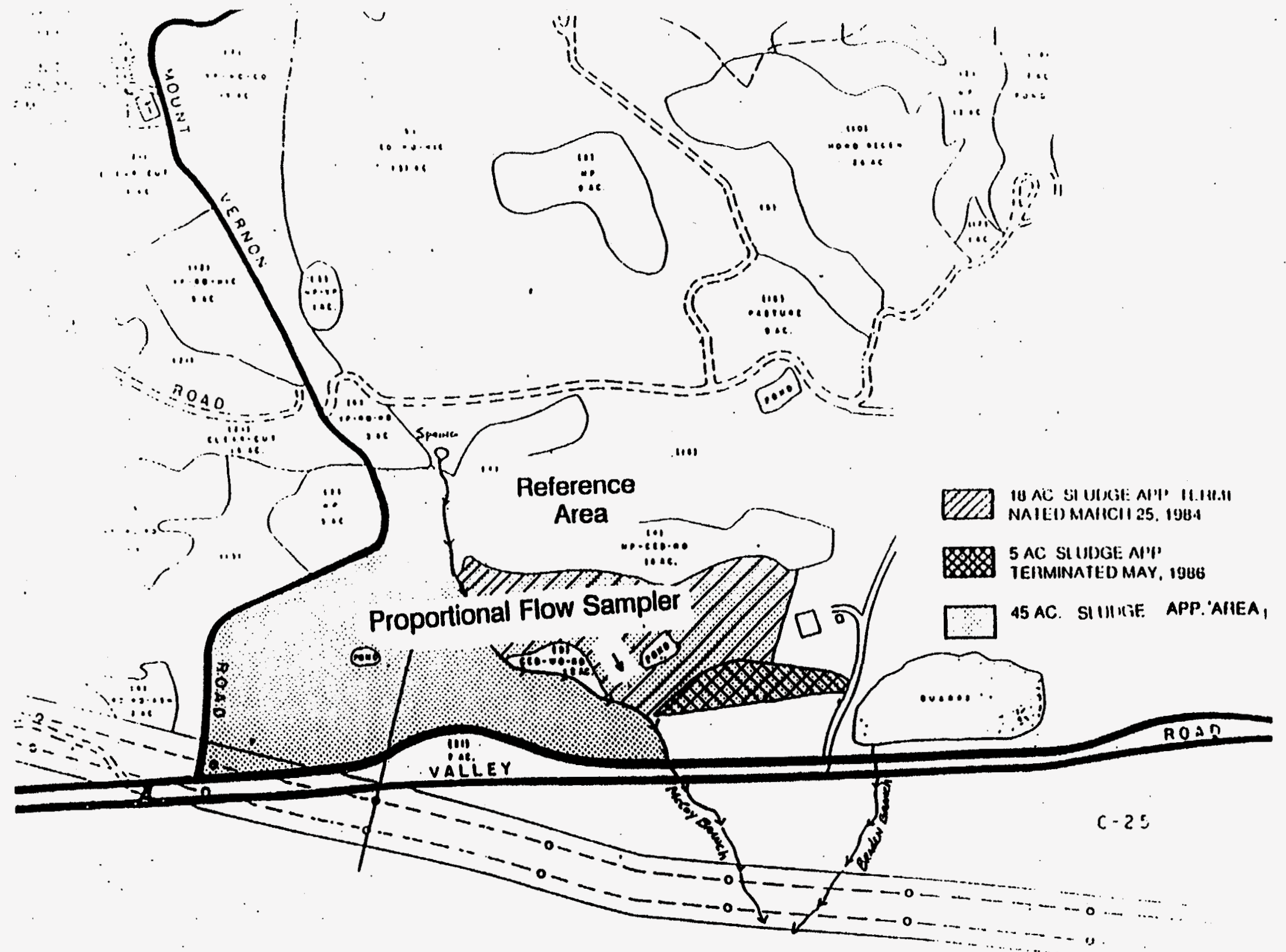

Fig. 3.2 The McCoy sludge application area showing reference area and location of proportional flow sample. 


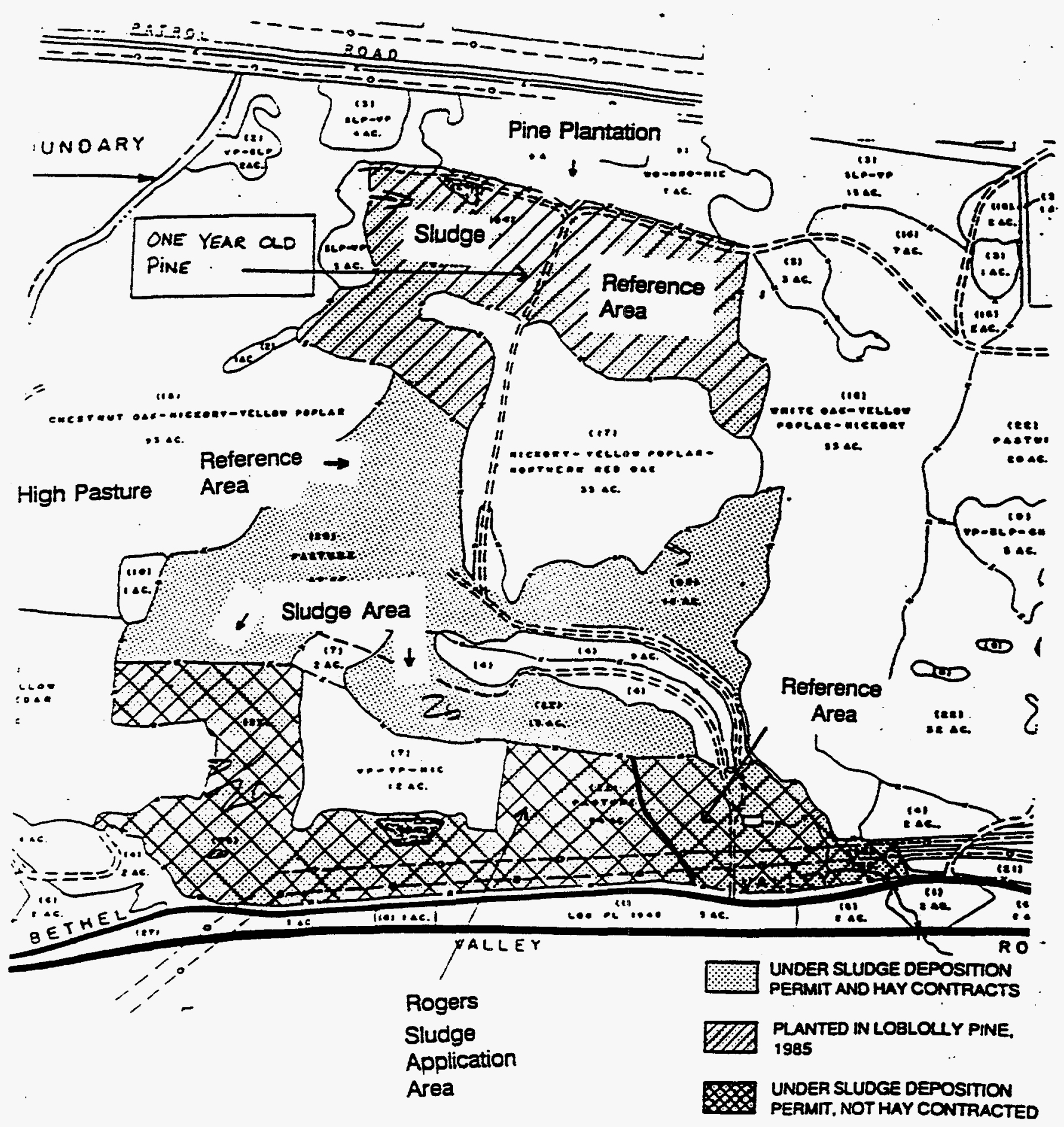

Fig. 3.3. Area 2, with the Pine Plantation at the top, the High Pasture in the center, and the Rogers Site at the bottom. Note reference areas as well as sludge application areas (not all permitted areas had sludge applied). Modified from ORNL DWG 88-5961. 


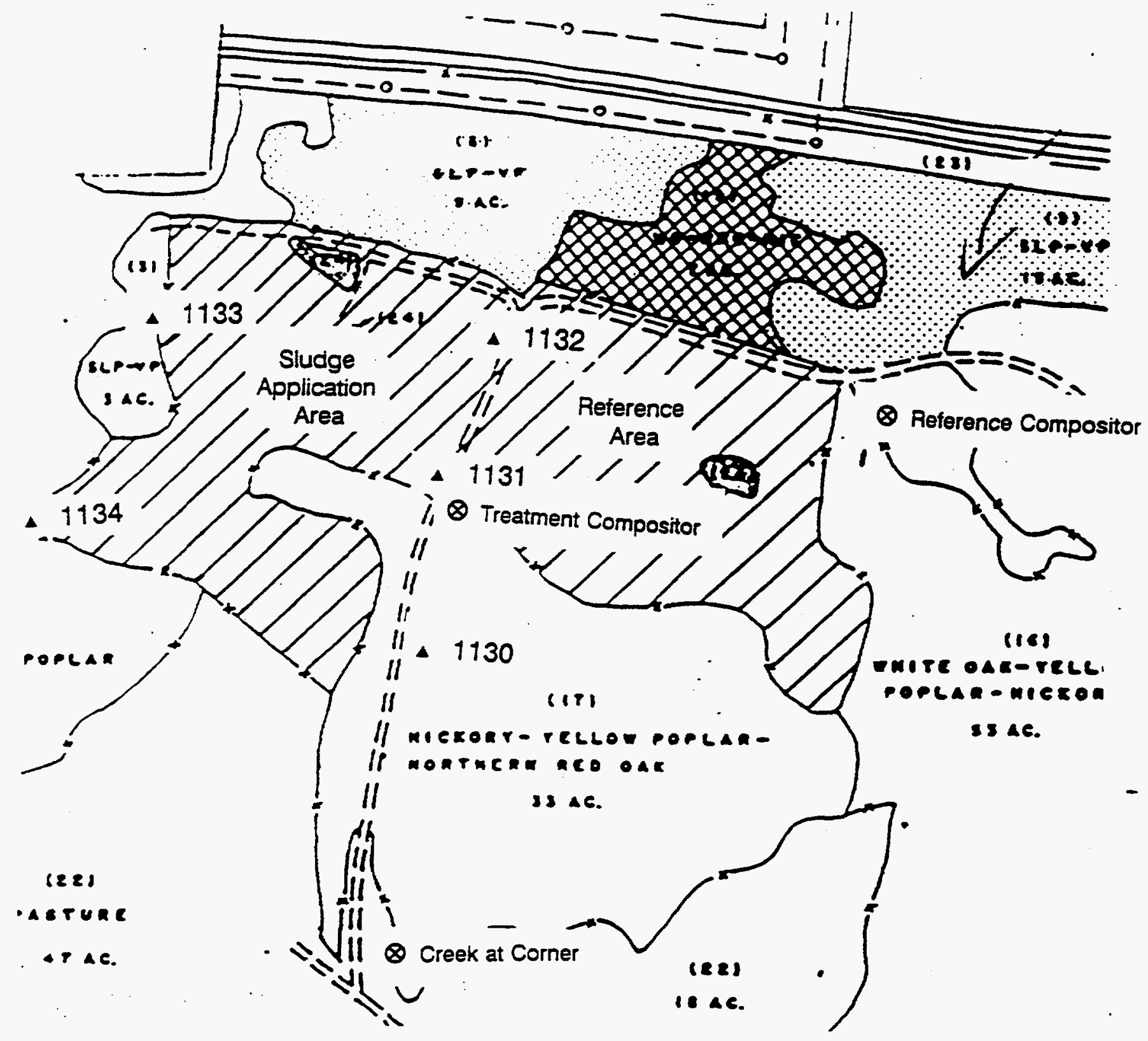

(8) Rock Wall

^Wells

Q Runoff Collection

Fig. 3.4. Detail of Pine Plantation showing application area and reference area, wells, and runoff collection sites. 


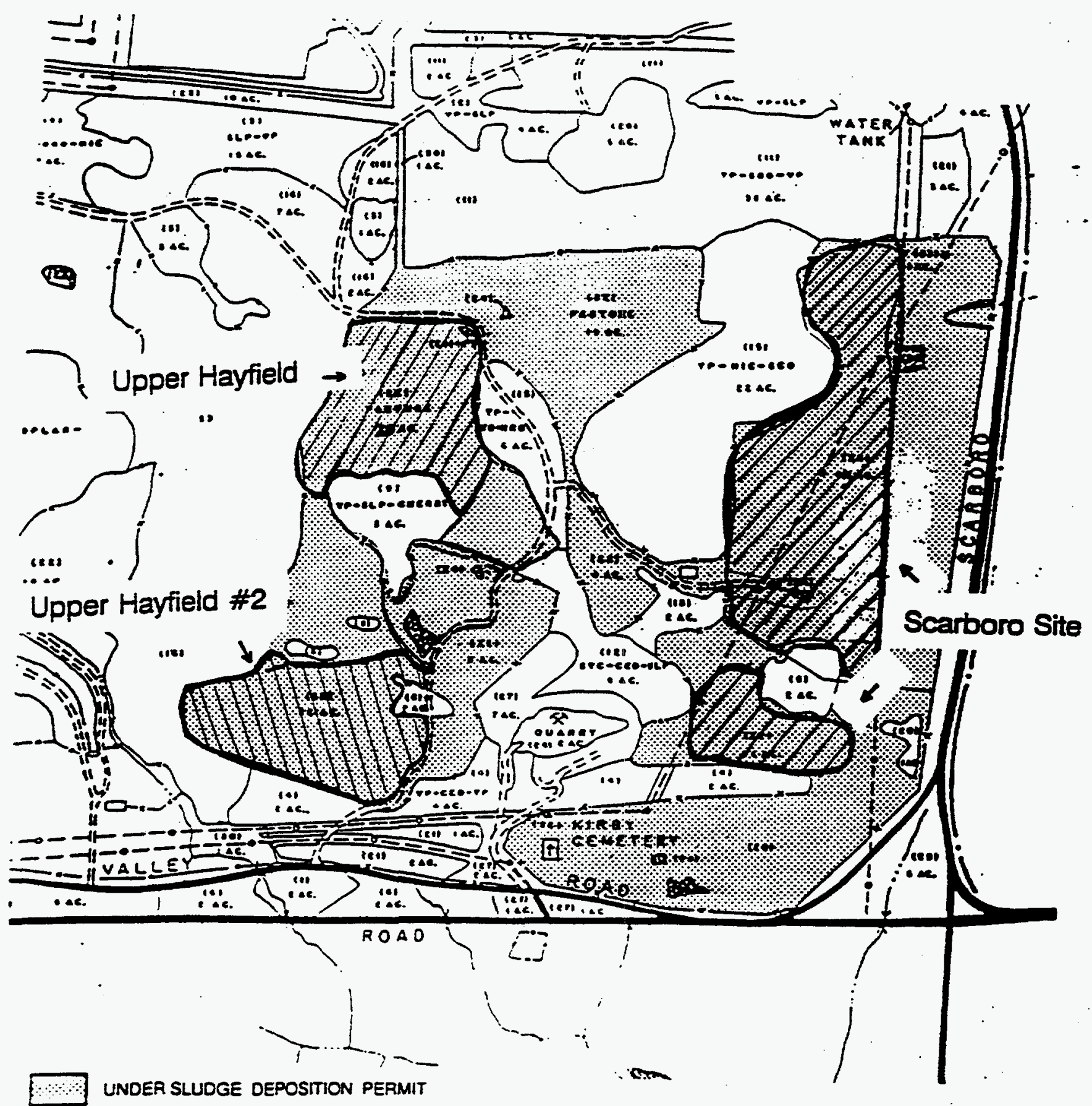

Fig. 3.5. Area 3, showing the Upper Hayfield Site, the Scarboro Site (two sections), and the Upper Hayfield 2 Site. There was not a designated reference area for these three sites, but samples from adjoining unsprayed pasture areas were used as references for all three. Modified from ORNL DWG 88-5962. 
Table 3.1 Sludge application sites and monitoring matrix

\begin{tabular}{|c|c|c|c|c|c|c|c|c|c|}
\hline Site & $\mathrm{McCoy}$ & Rogers & $\begin{array}{l}\text { Pine } \\
\text { Plantation }\end{array}$ & Cottonwood & $\begin{array}{l}\text { Watson } \\
\text { Road }\end{array}$ & Scarboro & $\begin{array}{l}\text { Upper } \\
\text { Hayfield }\end{array}$ & $\begin{array}{l}\text { Upper } \\
\text { Hayfield \#2 }\end{array}$ & $\begin{array}{l}\text { High } \\
\text { Pasture }\end{array}$ \\
\hline Application area & $\begin{array}{l}45-68 \text { ac } \\
(18-29 \text { ha })\end{array}$ & $\begin{array}{l}30 \text { ac } \\
(12 \text { ha })\end{array}$ & $\begin{array}{l}25 \text { ac } \\
\text { (10 ha) }\end{array}$ & $\begin{array}{l}17 \text { ac } \\
\text { ( } 7 \text { ha) }\end{array}$ & $\begin{array}{l}40 \text { ac } \\
\text { (16 ha) }\end{array}$ & $\begin{array}{l}45 \text { ac } \\
\text { (18 ha) }\end{array}$ & $\begin{array}{l}25 \mathrm{ac} \\
(10 \mathrm{ha})\end{array}$ & $\begin{array}{l}20 \mathrm{ac} \\
(8 \mathrm{ha})\end{array}$ & $\begin{array}{l}25 \mathrm{ac} \\
(10 \mathrm{ha})\end{array}$ \\
\hline Dates of application & $11 / 83-9 / 86$ & $9 / 86-12 / 88$ & $6 / 88-6 / 89$ & $6 / 89-5 / 91$ & $9 / 90-12 / 93^{a}$ & $8 / 90-7 / 93^{a}$ & $12 / 86-6 / 93^{a}$ & $11 / 89-7 / 93^{a}$ & $5 / 90-8 / 92^{a}$ \\
\hline $\begin{array}{l}\text { Application rate and } \\
\text { method }\end{array}$ & $\begin{array}{l}44 \mathrm{Mg} / \mathrm{ha} \\
\text { surface/injected }\end{array}$ & $\begin{array}{l}48 \mathrm{Mg} / \mathrm{ha} \text { surface/ } \\
\text { injected }\end{array}$ & $\begin{array}{l}27 \mathrm{Mg} / \mathrm{ha} \\
\text { surface }\end{array}$ & $\begin{array}{l}25 \mathrm{Mg} / \mathrm{ha} \\
\text { surface }\end{array}$ & $\begin{array}{l}29.7 \mathrm{Mg} / \mathrm{ha} \\
\text { surface }\end{array}$ & $\begin{array}{l}19.8 \mathrm{Mg} / \mathrm{ha} \\
\text { surface }\end{array}$ & $\begin{array}{l}30 \mathrm{Mg} / \mathrm{ha} \\
\text { surface }\end{array}$ & $\begin{array}{l}30.5 \mathrm{Mg} / \mathrm{ha} \\
\text { surface }\end{array}$ & $\begin{array}{l}19 \mathrm{Mg} / \mathrm{ha} \\
\text { surface }\end{array}$ \\
\hline $\begin{array}{l}\text { Total sludge applied } \\
\text { (dry weight) }\end{array}$ & $\begin{array}{l}871 \mathrm{ton} \\
792 \mathrm{mg}\end{array}$ & $\begin{array}{l}646 \text { ton } \\
587 \mathrm{mg}\end{array}$ & $\begin{array}{l}301 \mathrm{ton} \\
274 \mathrm{mg}\end{array}$ & $\begin{array}{l}193 \mathrm{ton} \\
175 \mathrm{mg}\end{array}$ & $\begin{array}{l}531 \text { ton } \\
475 \mathrm{mg}\end{array}$ & $\begin{array}{l}397 \mathrm{ton} \\
356 \mathrm{mg}\end{array}$ & $\begin{array}{l}334 \mathrm{ton} \\
303 \mathrm{mg}\end{array}$ & $\begin{array}{l}271 \mathrm{ton} \\
244 \mathrm{mg}\end{array}$ & $\begin{array}{l}201 \mathrm{ton} \\
180 \mathrm{mg}\end{array}$ \\
\hline Soil analyses & $\bullet, C$ & - & $\bullet$ & $\bullet$ & - & $\bullet$ & $\bullet$ & $\bullet$ & $\bullet$ \\
\hline Vegetation & & $\bullet$ & $\bullet$ & & & & & & \\
\hline Soil water & $C$ & - & $\bullet$ & $\bullet$ & & & & & \\
\hline Groundwater & $C$ & & $\bullet$ & & & & . & & \\
\hline Surface runoff & $\bullet, C$ & $\bullet$ & $\bullet$ & - & - & & & & \\
\hline
\end{tabular}

${ }^{a}$ Continues as an active site.

- = Analyses performed; $C=$ Some results previousiy reported, Oakes et al., 1984.

NOTE: the dates of sludge application, the areas, loading rate and application methods, and total dry weight of sludge applied to each site (through 1993) are given. The methods of application included surface application from behind the truck and/or from a truck-mounted spray nozzle ("surface"), and subsurface injection and plowing ("injected"). The environmental media sampled and analyzed for each site as part of the monitoring program are also indicated. 
McCoy Site (No. 1 on Fig. 3.1, Fig. 3.2)

From November 1983 through September 1986, sludge was applied to a 29-ha (68-acre) pasture (referred to as the "McCoy Site") near Bethel Valley Road at Mount Vernon Road. Most of the sludge was spread on an 18-ha (45-acre) main application area, with an application rate of approximately $44 \mathrm{Mg} / \mathrm{ha}$ (18.7 tons/acre). Sludge was applied directly to the surface and by subsurface injection. The application site was occasionally tilled to a depth of about $15 \mathrm{~cm}$. The site is officially closed. (Additional information on this site, including description and monitoring results may be found in Oakes, et al., 1984.)

\section{Rogers Site (lower part of site No. 2 on Figs. 3.1 and 3.3)}

Sludge was applied to this 12-ha (30-acre) pasture site on Bethel Valley Road between September 1986 and December 1988 by a combination of subsurface injection (10-cm depth) and surface application, for a total of $48.2 \mathrm{Mg} / \mathrm{ha}$. Monitoring was done at three slope positions (upper, middle, and lower portions of the slope). After June 1988, most sludge went to the Pine Plantation site described below, except during wet weather. A small portion of the sludge applied to the eastern portion of the Rogers site was mixed with cement kiln dust as a thickener and $\mathrm{pH}$ adjustment (liming substitute). A similar pasture further to the east on Bethel Valley Road was available as a reference (Fig. 3.3). This site is officially closed.

\section{Pine Plantation Site (upper part of site No. 2 on Figs. 3.1 and 3.3. See also Fig. 3.4)}

This 10-ha (25-acre) plantation of 4-year-old loblolly pine (Pinus taeda L) trees growing on Chestnut Ridge was sprayed with $27 \mathrm{Mg} / \mathrm{ha}$, applied over the canopy with a spray nozzle mounted on the delivery vehicle. This site was used between June 1988 and June 1989 and was set up as an experimental system to assess the effects of sludge application on the growth of pines and the quality of groundwater. The sludge application area was subdivided into sections with sludge only and sections with either sawdust application (to temporarily immobilize nitrogen) or herbicide application (to reduce growth of weeds within the pine stand, reducing total $\mathbf{N}$ uptake into plants and potentially causing $\mathbf{N}$ to be leached more rapidly from the system). Monitoring was done by plot within each treatment section and at three slope positions (upper, middle, and lower portions of the slope). Three 20-m $\times 30-\mathrm{m}$ plots were set out in each sludge treatment section (one per slope position). Three reference plots were also included in the experimental design. This site is officially closed.

\section{Cottonwood Site (No. 11 on Fig. 3.1)}

This 7-ha (17-acre) site of cottonwood saplings was used three times, beginning June-September 1989 and again in January and February 1990 and April through May 1991, for a total of eight months. Sludge was sprayed into the stand from roads within the stand as in the pine plantation. No sludge has been applied to this site since 1991, but the cumulative loading rates have not been exceeded, and the site is not officially closed. Total application has been $25.4 \mathrm{Mg} / \mathrm{ha}$.

\section{Site 8 (part of site No. 8 on Fig. 3.1)}

This 4.8-ha (12-acre) site was used only in March and April 1990. Approximately $40 \mathrm{dry}$ tons of sludge were applied to this site by surface application. This site was abandoned because sludge accumulated on the surface leaf litter and moved down the slope. No monitoring data are available from this site. 
Watson Road Site (No. 9 on Fig. 3.1)

Approximately 16 ha (40 acres) of woodland at this site (partly mixed hardwood, and partly mature loblolly pine plantation) has been used for application of sludge by spraying into the woods with the truck-mounted spray nozzle. This site has been used four times, from September to December 1990, from June through October 1991, and from August through December 1992, and again, July through December 1993 . A total of $29.7 \mathrm{Mg} / \mathrm{ha}$ had been applied through 1993. The site is still in active use by the ongoing sludge application program.

Scarboro Site (eastern portion of site No. 3 on Figs. 3.1 and 3.5)

Approximately 18 ha (45 acres) of this large hayfield site have been used for surface application of sludge, beginning in August 1990. Application continued until October of 1990 , was repeated during January, February, June, and July 1991, and again from November 1991 until May 1992. Sludge was applied again from January through July of 1993. During some of these periods, but on different days, sludge also was applied to Upper Hayfields 1 and 2. Total sludge applied to the Scarboro Site by the end of 1993 was $19.8 \mathrm{Mg} / \mathrm{ha}$. This site is still active.

Upper Hayfield, or Upper Hayfield 1, or "the Wet Weather Site" (northwest portion of site No. 3 on Figs. 3.1 and 3.5)

This 10-ha (25-acre) hayfield has been used intermittently since December 1986, originally only when the soil was too wet on the somewhat steeper regular site (Rogers) for the application vehicle to maneuver safely, and later as part of the overall site rotation schedule. Sludge was applied from December 1986 to April 1987, from December 1988 through April 1989, and from August through December 1989. The site was used again in February 1990, February through March 1991, March through May 1992, and again from January through June 1993, all by surface application (spraying). Despite the long period that sludge has been applied (intermittently), only $30 \mathrm{Mg} / \mathrm{ha}$ of sludge was applied to this site through 1993. This site is still active.

\section{Upper Hayfield 2 (southwest portion of site No. 3 on Figs. 3.1 and 3.5)}

This 8-ha (20-acre) hayfield near Upper Hayfield No. 1 has been in use since November/ December 1989. It was used again in March and April 1990, April and October/November 1991, from March to May 1992, and again in 1993, from January through July. A total of $30.5 \mathrm{Mg} / \mathrm{ha}$ was applied through the end of 1993. This site is still active.

\section{High Pasture Site or Rogers High Pasture (middle section of site No. 2 on Figs. 3.1 and 3.3)}

This 10-ha (25-acre) hayfield was first used for sludge application between May and July 1990 , when the annual allowable loading rate, based on $\mathrm{N}$, was exceeded by 0.5 ton/acre (the 12-month running average concentration of $\mathrm{N}$ limited loading to 4.1 ton/acre during this period). No sludge was applied to this site in 1991, but application resumed from May to August 1, 1992. No sludge was applied in 1993 because of site access problems, but the site is still part of the ongoing sludge land application program. A total of $18 \mathrm{Mg} /$ ha of sludge was been applied to this site by surface application through 1993. 


\subsection{MONITORING AT EACH SITE}

The scope and intensity of the formal monitoring program varied over its lifetime as specific questions arose and as others were answered. Table 3.1 indicates the media that were monitored at each site and for which data are available. Those data are discussed in subsequent sections of this report. Table 3.1 also summarizes the application information from each site.

The majority of the initial monitoring data from the McCoy Site was collected after sludge application had ended, although some data were collected in March 1984. Radiological sampling of soil and air was performed at that time because it was determined that the sludge then being applied was contaminated with ${ }^{137} \mathrm{Cs}$ and ${ }^{60} \mathrm{Co}$ (Oakes, et al., 1984). Postapplication sampling addressed soil levels of metals, nutrients, and radionuclides as well as stream and sediment levels of these parameters plus organics. Soil water, groundwater, and surface runoff were analyzed for metals, nitrates, organics, and radionuclides. Runoff was analyzed for fecal coliform bacteria. Specific sampling methods will be addressed in later sections on soil and water.

The Rogers and Pine Plantation sites were the most thoroughly monitored sites. Data were collected from soil and vegetation, from soil water (using lysimeters), from groundwater (wells, Pine site only), and surface runoff. Sampling was performed before (Pine only), during, and after sludge application. Soil, groundwater, and surface runoff from the Cottonwood site were also analyzed. Later sites (Watson Road, Scarboro, Hayfields, and High Pasture) were monitored chiefly for changes in soil chemistry, which is the only environmental monitoring required by state regulations. Limited measurements of surface runoff at the Watson Road site were also made. Monitoring of sludge characteristics (chemistry and radionuclide analysis) has also continued throughout the application and monitoring program.

\subsection{APPLICATION RATE AND CUMULATTVE LOADING OF SPECIFIC CONSTITUENTS: COMPARISON WITH REGULATORY LIMITS}

The cumulative sludge application rate, in $\mathrm{Mg} /$ ha (dry weight), is given in Table 3.1 for each site as of December 1993. At that point, the greatest application rate had been to the Rogers Site (44 Mg/ha) and the least to the High Pasture Site (18 Mg/ha).

Annual sludge application, as mentioned previously, is limited by the total nitrogen concentration in the sludge, based on the fertilizer requirements of the vegetation growing on the site, according to state guidelines in the land application permit. Based on the average nitrogen concentration in the sludge, the average allowable annual sludge application rate was $9.8 \mathrm{Mg} /$ ha/year (4.38 tons/acre). Actual annual application rates for each site were determined using the 12-month running average of nitrogen concentration.

The cumulative loading rates for each of the regulated metals mentioned in Sect. 2.4 can be calculated from the average concentrations of each of these metals during the active application period for each site (Table 3.2) and the total sludge loading rates in Table 3.1. Those calculated loading rates for each site are given in Table 3.3, along with the regulatory limits from Table 2 of 40 CFR 503.13. As this table shows, none of the site loading rates have approached the regulatory limits. 
Table 3.2. Average concentration of metals in sludge during the application period for each site (mg/kg), based on the yearly concentrations in Table 2.1 and the dates of application (averages are calculated through 1993)

\begin{tabular}{|c|c|c|c|c|c|c|c|c|c|}
\hline Metal & McCoy & Rogers & Pine & Cottonwood & $\begin{array}{l}\text { Watson } \\
\text { Raad }\end{array}$ & $\begin{array}{l}\text { Upper } \\
\text { Hayfield }\end{array}$ & $\begin{array}{c}\text { Upper } \\
\text { Hayfield No. } 2\end{array}$ & High Pasture & Scarboro \\
\hline As & 9.3 & 5.1 & 5.1 & 4.9 & 4.9 & 4.9 & 4.8 & 5.1 & 4.9 \\
\hline Cd & 14.0 & 10.5 & 8.4 & 7.9 & 9.8 & 9.6 & 9.2 & 10.5 & 9.8 \\
\hline $\mathrm{Cr}$ & 630 & 359 & 195 & 155 & 153 & 215 & 157 & 158 & 153 \\
\hline $\mathrm{Cu}$ & 1150 & 687 & 537 & 486 & 474 & 538 & 479 & 473 & 474 \\
\hline $\mathrm{Pb}$ & 220 & 201 & 142 & 94 & 81 & 120 & 88 & 79 & 81 \\
\hline $\mathrm{Hg}$ & 15.3 & 17.8 & 12.5 & 11.1 & 10.3 & 12.2 & 10.0 & 8.9 & 10.3 \\
\hline Mo & n.d. & 60.0 & 39.0 & 23.8 & 26.4 & 30.6 & 24.7 & 26.8 & 26.4 \\
\hline $\mathbf{N i}$ & 143 & 90.0 & 53.1 & 44.1 & 42.5 & 55.7 & 42.0 & 42.8 & 42.5 \\
\hline $\mathrm{Se}$ & 6.7 & 6.7 & 7.0 & 6.8 & 6.9 & 6.9 & 6.9 & 6.6 & 6.9 \\
\hline $\mathrm{Zn}$ & 2718 & 2169 & 1852 & 1735 & 1706 & 1838 & 1705 & 1697 & 1706 \\
\hline
\end{tabular}

n.d. indicates that no data were available for this metal during the application period for that site.

Table 3.3. Total sludge applied (kg/ha) on each site and cumulative metal loading (as of December 1993) for each site, compared to regulatory limits (Table 2 of 40 CFR 503.13)

\begin{tabular}{|c|c|c|c|c|c|c|c|c|c|c|}
\hline & McCoy & Rogers & Pine & Cottonwood & $\begin{array}{c}\text { Watson } \\
\text { Road }\end{array}$ & $\begin{array}{c}\text { Upper } \\
\text { Hayfield }\end{array}$ & $\begin{array}{c}\text { Upper } \\
\text { Hayfield } \\
\# 2\end{array}$ & $\begin{array}{c}\text { High } \\
\text { Pasture }\end{array}$ & Scarboro & $\begin{array}{l}\text { Permissible cumulative } \\
\text { pollutant loading rates } \\
\text { (kg/ha) }\end{array}$ \\
\hline \multicolumn{11}{|c|}{ Total shudge applied to each site: (kg/ha) } \\
\hline & 44000 & 48200 & 27000 & 25400 & 29700 & 36400 & 30500 & 18000 & 19800 & \\
\hline \multicolumn{11}{|c|}{ Cumulative loading of each metal per site: (kg/ha) } \\
\hline As & 0.4 & 0.2 & 0.1 & 0.1 & 0.1 & 0.2 & 0.1 & 0.1 & 0.1 & 41 \\
\hline $\mathrm{Cd}$ & 0.6 & 0.5 & 0.2 & 0.2 & 0.3 & 0.3 & 0.3 & 0.2 & 0.2 & 39 \\
\hline $\mathrm{Cr}$ & 27.7 & 17.3 & 5.3 & 3.9 & 4.6 & 7.8 & 4.8 & 2.8 & 3.0 & 3000 \\
\hline $\mathrm{Cu}$ & 50.6 & 33.1 & 14.5 & 12.3 & 14.1 & 19.6 & 14.6 & 8.5 & 9.4 & 1500 \\
\hline $\mathrm{Pb}$ & 9.7 & 9.7 & 3.8 & 2.4 & 2.4 & 4.4 & 2.7 & 1.4 & 1.6 & 300 \\
\hline $\mathrm{Hg}$ & 0.7 & 0.9 & 0.3 & 0.3 & 0.3 & 0.4 & 0.3 & 0.2 & 0.2 & 17 \\
\hline Mo & n.d. & 2.9 & 1.1 & 0.6 & 0.8 & 1.1 & 0.8 & 0.5 & 0.5 & 18 \\
\hline $\mathrm{Ni}$ & 6.3 & 4.3 & 1.4 & 1.1 & 1.3 & 2.0 & 1.3 & 0.8 & 0.8 & 420 \\
\hline $\mathrm{Se}$ & 0.3 & 0.3 & 0.2 & 0.2 & 0.2 & 0.2 & 0.2 & 0.1 & 0.1 & 100 \\
\hline $\mathrm{Zn}$ & 119.6 & 104.5 & 50.0 & 44.1 & 50.7 & 66.9 & 52.0 & 30.6 & 33.8 & 2800 \\
\hline
\end{tabular}




\section{SOIL}

\subsection{METHODS OF SAMPLING AND ANALYSIS}

Soil core samples were taken periodically (see results for sampling dates at specific sites) from each of the sludge application areas, and from reference plots adjacent to or near the application plots, which were similar in terms of topography and vegetation type. Samples were taken with a stainless steel soil probe or auger, generally from the upper $0-15 \mathrm{~cm}$ of the soil, but, in some cases, also from deeper soils and occasionally in smaller increments in the shallow soils. For most samples, six to ten cores taken from each topographic area of a site were composited prior to chemical analysis (Van Miegroet, et al., 1989). For sites where samples were taken at multiple slope positions, position did not affect soil metal concentrations (Van Miegroet, et al., 1989), and averages were calculated across all slope positions. Soil analyses included $\mathrm{pH}$, total Kjeldahl nitrogen (TKN), cation exchange capacity (CEC), metals, and radionuclides. Inductively coupled plasma atomic emission spectrometry (ICP) provided some elemental analyses (e.g., metals) with later analyses for cadmium done by graphite furnace atomic absorption spectrophotometry (AA) to improve the detection limits. TKN, pH, CEC, and ICP analyses were done by ORNL Analytical Chemistry Division; A\&L Agricultural Laboratory of Memphis, Tennessee; University of Georgia Soil Testing and Plant Analysis Laboratory; and Analytical Resources in Seattle, Washington. Total uranium was measured by Elbert Carlton of ORAU by the neutron activation method. Other radionuclides were measured by $\mathrm{I}$. L. Larsen of ORNL ESD by gamma ray spectrometry.

\subsection{RESULTS}

\subsubsection{Soil Conditioning-Nitrogen, pH, Cation Exchange Capacity}

The major benefit of land application of municipal sewage sludge is the fertilization and improvement of the physical properties of soil (soil conditioning) resulting from the high organic matter and nutrient content of the sludge (e.g., N, P, K concentrations), as illustrated in Table 2.1. Table 4.1 compares the concentrations of total soil nitrogen (Kjeldahl method) at eight sludge application sites and their associated reference areas. In all post-treatment soils analyzed, $N$ levels were slightly higher in the top $0-15 \mathrm{~cm}$ of sludge-amended soils than in reference soils one month to twelve years after sludge application. Because of high variability in the $\mathrm{N}$ values, however, the higher $\mathrm{N}$ concentration was statistically significant only at the Sycamore Site.

At the Pine Plantation site, the sludge-application plots had lower $\mathbf{N}$ concentrations than did the reference plots before the applications began (pretreatment values, Table 4.1), and this relationship was reversed in the upper soil layer $(0-15 \mathrm{~cm})$ after one year of sludge application. A comparison of the soil $\mathrm{N}$ concentrations before and after sludge application on a plot-by-plot basis (plots described in Sect. 3.2, paired t-tests) shows that the $\mathrm{N}$ concentrations were significantly higher in the top $0-15 \mathrm{~cm}$ after sludge application (Table 4.1). The Pine Plantation sludge application area was divided into plots with and without sawdust application (to immobilize and retain the $\mathrm{N}$ ) or herbicide application (to reduce understory vegetation and potentially cause $\mathrm{N}$ to be lost from the system-see Sect. 3.2). However, there were no differences in postapplication soil $\mathrm{N}$ among any of the 
Table 4.1. Concentrations of soil nitrogen (total Kjehldahl N, mg/kg) at eight sludge application sites before, during, or after sludge application, comparing sludge-treated and reference soils ${ }^{a}$

\begin{tabular}{lllllc}
\hline & $\begin{array}{l}\text { Date of most } \\
\text { recent sludge }\end{array}$ & $\begin{array}{l}\text { Sampling } \\
\text { date }\end{array}$ & $\begin{array}{l}\text { Soil } \\
\text { Depth } \\
\text { Site }\end{array}$ & (cm) & \multicolumn{2}{c}{ Nitrogen, ppm (mean \pm Std) } \\
\cline { 5 - 6 } Sycamore & 1978 & $7 / 90$ & $0-15$ & $1740 \pm 185^{c}$ & $1293 \pm 103$ \\
McCoy & $9 / 86$ & $7 / 90$ & $0-15$ & $1976 \pm 534$ & $1543 \pm 465$ \\
Rogers & $12 / 88$ & $7 / 90$ & $0-15$ & $2353 \pm 978$ & $1903 \pm 827$ \\
Pine $^{b}$ & (Pretreatment) & $3 / 88$ & $0-15$ & $1230 \pm 56$ & $1467 \pm 168$ \\
& (Pretreatment) & $3 / 88$ & $15-30$ & $363 \pm 78$ & $453 \pm 165$ \\
& (Pretreatment) & $3 / 88$ & $30+$ & $257 \pm 21^{c}$ & $407 \pm 84$ \\
Pine ${ }^{b}$ & $6 / 89$ & $11 / 89$ & $0-15$ & $1733 \pm 206^{d}$ & $1537 \pm 216$ \\
& $6 / 89$ & $11 / 89$ & $15-30$ & $400 \pm 98$ & $553 \pm 270$ \\
& $6 / 89$ & $11 / 89$ & $30+$ & $240 \pm 30$ & $390 \pm 225$ \\
Cottonwood & $2 / 90$ & $7 / 90$ & $0-15$ & $2190 \pm 702$ & $1187 \pm 309$ \\
& $2 / 90$ & $1 / 91$ & $0-15$ & $1867 \pm 605$ & $1041 \pm 59$ \\
Scarboro & $10 / 90$ & $1 / 91$ & $0-15$ & $1460 \pm 369$ & $1383 \pm 221$ \\
Upper & $12 / 89$ & $1 / 91$ & $0-15$ & $1509 \pm 389$ & $\uparrow$ \\
Hayfield 1 & & & & & 4 \\
Upper & $4 / 90$ & $1 / 91$ & $0-15$ & $1500 \pm 503$ & \\
Hayfield 2 & & & & &
\end{tabular}

${ }^{a}$ Time elapsed between the last sludge application and the posttreatment sampling varied but may be determined from the dates provided. Samples were take from a depth of $0-15 \mathrm{~cm}$, except as indicated for the Pine site. Samples were taken from three plots on each site.

${ }^{b}$ For the Pine site, "sludge-treated" indicates the mean for the "sludge-only" plots-see text.

Means for treated and reference sites are different at the $p=0.05$ level (t-test).

${ }^{d}$ (Pine site only) difference between $\mathrm{N}$ concentrations in each plot before and after sludge application was significantly different from zero (paired t-test, $\mathrm{p}<0.05$ ).

NOTE: $\uparrow=$ no separate reference samples were taken for the Upper Hayfield sites, but the reference from the nearby Scarboro hayfield site may be taken as representative.

sludge-treated plots in the Pine Plantation experiment, regardless of additional treatment. The data from the "sludge-only" plots are presented in Table 4.1, but post-treatment $\mathrm{N}$ concentrations were significantly higher than the pretreatment concentrations in all three sludge treatments. Table 4.4 shows the mean $\mathrm{N}$ concentration across all three types of sludge treatment plots.

Additional measurements of soil nitrogen as well as soil $\mathrm{Pb}$ and cation exchange capacity presented in Table 4.2 are from soil samples taken in January 1991 and show residual effects from past application on the Rogers and Pine sites and the effects of more recent sludge application on the Cottonwood Plantation Site and the four grassy sites designated Scarboro, Hayfield 1, Hayfield 2, and High Pasture. As noted before, soil nitrogen concentrations were slightly, but not significantly, higher in sludge-application areas. There were no apparent trends in either CEC or soil pH with sludge treatment, although differences were statistically significant (see Table 4.2) in three cases: one higher CEC, one lower CEC, and a lower $\mathrm{pH}$ in one case. 
Table 4.2 Concentrations of soil nitrogen (TKN, total Kjeldahl N, ppm), cation exchange capacity (CEC, meq/100 $\mathrm{g}$ soil), and soil $\mathrm{pH}$ at seven sludge application sites and associated reference sites

\begin{tabular}{|c|c|c|c|c|c|c|c|}
\hline \multirow[b]{2}{*}{ Site } & \multirow{2}{*}{$\begin{array}{l}\text { Date of } \\
\text { most } \\
\text { recent } \\
\text { studge } \\
\text { applic. }\end{array}$} & \multicolumn{2}{|c|}{$\begin{array}{l}\text { Nitrogen, ppm } \\
\text { (Mean } \pm \text { Std) }\end{array}$} & \multicolumn{2}{|c|}{ CEC, meq/100g } & \multicolumn{2}{|c|}{ pH } \\
\hline & & $\begin{array}{l}\text { Sludge- } \\
\text { treated }\end{array}$ & Ref & $\begin{array}{l}\text { Sindge- } \\
\text { treated }\end{array}$ & Ref & $\begin{array}{l}\text { Sludge- } \\
\text { treated }\end{array}$ & Ref. \\
\hline Rogers & $12 / 88$ & $\begin{array}{r}1351 \\
\pm 1038\end{array}$ & $\begin{array}{r}1201 \\
\pm 436\end{array}$ & $\begin{aligned} & 1.57^{d} \\
\pm & 0.35\end{aligned}$ & $\begin{array}{r}11.05 \\
\pm 2.05\end{array}$ & $\begin{array}{r}5.4 \\
\pm 0.5\end{array}$ & $\begin{array}{r}5.4 \\
\pm 0.1\end{array}$ \\
\hline Pine $^{b}$ & $6 / 89$ & $\begin{array}{r}1780^{\circ} \\
\pm 126\end{array}$ & $\begin{array}{r}1732 \\
\pm 1056\end{array}$ & $\begin{aligned} & 9.80^{d} \\
\pm & 1.10\end{aligned}$ & $\begin{array}{r}5.10 \\
\pm 4.75\end{array}$ & $\begin{array}{r}3.8 \\
\pm 0.4\end{array}$ & $\begin{array}{r}4.8 \\
\pm 0.4\end{array}$ \\
\hline Cottonwood & $2 / 90$ & $\begin{array}{r}1867^{c} \\
\pm 605\end{array}$ & $\begin{array}{l}1041^{c} \\
\pm 59\end{array}$ & $\begin{array}{r}10.80 \\
\pm 3.53\end{array}$ & $\begin{array}{r}6.70 \\
\pm 0.42\end{array}$ & $\begin{array}{r}4.5 \\
\pm 0.6\end{array}$ & $\begin{array}{r}4.8 \\
\pm 0.4\end{array}$ \\
\hline Scarboro & $10 / 90$ & $\begin{array}{r}1460^{\circ} \\
\pm 369\end{array}$ & $\begin{array}{r}1383^{c} \\
\pm 221\end{array}$ & $\begin{array}{r}6.10 \\
\pm 1.31\end{array}$ & $\begin{array}{r}8.55 \\
\pm 1.34\end{array}$ & $\begin{array}{r} \\
4.4^{d} \\
\pm 0.1\end{array}$ & $\begin{array}{r}5.0 \\
\pm 0.0\end{array}$ \\
\hline $\begin{array}{l}\text { Upper } \\
\text { Hayfield } 1\end{array}$ & $12 / 89$ & $\begin{array}{r}1509^{c} \\
\pm 389\end{array}$ & $\uparrow$ & $\begin{array}{r}8.63 \\
\pm 2.67\end{array}$ & $\uparrow$ & $\begin{array}{r}4.7 \\
\pm 0.4\end{array}$ & $\uparrow$ \\
\hline $\begin{array}{l}\text { Upper } \\
\text { Hayfield } 2\end{array}$ & $4 / 90$ & $\begin{array}{r}1500^{c} \\
\pm 504\end{array}$ & $\uparrow$ & $\begin{array}{c}9.93 \\
\pm .072\end{array}$ & $\uparrow$ & $\begin{array}{r}5.1 \\
\pm 0.1\end{array}$ & $\uparrow$ \\
\hline High Pasture & $7 / 90$ & $\begin{array}{r}1523 \\
\pm 1210\end{array}$ & $\uparrow$ & $\begin{array}{r}7.10 \\
+1.39\end{array}$ & $\uparrow$ & $\begin{array}{r}4.1 \\
\pm 0.2\end{array}$ & $\uparrow$ \\
\hline
\end{tabular}

\footnotetext{
${ }^{a}$ Samples were taken on January 17, 1991, from the upper 0-15 cm. Samples were taken from 3 plots on each sludge site, and from 2 on each reference (Ref.) site. TKN and CEC were measured by Analytical Resources, Inc., Seattle, Washington. Measurements of $\mathrm{pH}$ were done at Environmental Sciences Division, Oak Ridge National Laboratory.

${ }^{b}$ For the Pine site, "sludge-treated" indicates the mean for the "sludge-only" plots-see text for details.

These TKN data also appear in table 4.1.

${ }^{d}$ Means for treated and reference sites are different at the $p=0.05$ level (t-test).

NOTE: $\uparrow=$ no separate reference samples were taken for the Upper Hayfield or High Pasture sites, but the references from the nearby Scarboro hayfield and Rogers pasture sites may be taken as representative.
}

\subsubsection{Metals and radionuclides}

The land application of sludge may be expected to increase soil concentrations of elements such as $\mathrm{Ca}, \mathrm{Zn}, \mathrm{Cu}$, and $\mathrm{Cd}$, depending on the concentrations in the sludge and the loading rates used. For example, at the Rogers site, an increase in soil concentrations of $\mathrm{Ag}$, $\mathrm{Cd}, \mathrm{Cr}, \mathrm{Cu}, \mathrm{K}, \mathrm{P}, \mathrm{Pb}$, and $\mathrm{Zn}$ may be expected, based on calculations of average concentrations in sludge during the application period (Table 3.2) and the amount of sludge applied to the site (Table 3.1). Table 4.3 confirms concentrations significantly higher in sludge-treated soils than in reference soils for $\mathrm{Ca}, \mathrm{P}, \mathrm{Zn}, \mathrm{U}$, and $\mathrm{Cs}$ (only in the top $15 \mathrm{~cm}$ ), some increase in $\mathrm{Zn}$ (not significant), and much smaller (not significant) changes in $\mathrm{Cd}, \mathrm{Cu}$, or $\mathrm{Pb}$. 
Table 4.3. Concentrations of ICP analytes, uranium, and radionuclides in soil at the Rogers Site, at two soil depths, from sludge-treated and reference soils ${ }^{\natural}$

\begin{tabular}{|c|c|c|c|c|c|c|c|c|}
\hline & \multicolumn{4}{|c|}{ Sludge-treated site } & \multicolumn{4}{|c|}{ Reference site } \\
\hline & \multicolumn{2}{|c|}{$0-15 \mathrm{~cm}$} & \multicolumn{2}{|c|}{$15-30 \mathrm{~cm}$} & \multicolumn{2}{|c|}{$0-15 \mathrm{~cm}$} & \multicolumn{2}{|c|}{$15-30 \mathrm{~cm}$} \\
\hline & Mean & Std & Mean & Std & Mean & Std & Mean & Std \\
\hline $\mathrm{Ag}$ & 2.54 & 1.37 & $<0.38$ & 0 & $<0.3$ & -- & $<0.3$ & -- \\
\hline As & $<3.0$ & & $<3.0$ & & $<3.0$ & - & $<3.0$ & $\cdots$ \\
\hline $\mathrm{Ca}$ & $4300^{b}$ & 2690 & 1795 & 1019 & 1333 & 115 & 1090 & 315 \\
\hline $\mathrm{Cd}$ & $<0.58$ & 0.06 & $<0.44$ & 0.05 & $<0.3$ & -- & $<0.3$ & -- \\
\hline $\mathrm{Co}$ & 16.2 & 6.1 & 16.3 & 5.7 & 14.9 & 7.4 & 14 & 2.6 \\
\hline $\mathrm{Cr}$ & 22.8 & 7.1 & 17.5 & 4.3 & 26.3 & 7.8 & 21 & 7.2 \\
\hline $\mathrm{Cu}$ & 23.0 & 6.1 & $8.1^{b}$ & 1.3 & 14.0 & 4.4 & 14.0 & 3.0 \\
\hline $\mathrm{K}$ & 955 & 691 & 498 & 388 & 637 & 526 & 757 & 289 \\
\hline $\mathrm{Mg}$ & 1210 & 494 & 900 & 313 & 1203 & 693 & 867 & 126 \\
\hline $\mathrm{Mn}$ & 2266 & 327 & 1907 & 7.6 & 1323 & 999 & 1333 & 664 \\
\hline Mo & $<2.4$ & & $<2.4$ & & $<2.4$ & & $<2.4$ & \\
\hline $\mathrm{Ni}$ & 13 & 2.8 & 11.2 & 2.6 & 10.4 & 2.4 & 9.0 & 3.0 \\
\hline $\mathbf{P}$ & $1057 b$ & 215 & 250 & 81.5 & 250 & 14 & 172 & 113 \\
\hline $\mathrm{Pb}$ & 39.5 & 17.7 & 31.7 & 13.3 & 23.8 & 16.4 & 21.3 & 5.0 \\
\hline $\mathrm{Se}$ & $<3.0$ & & $<3.0$ & & $<3.0$ & & $<3.0$ & \\
\hline $\mathrm{Zn}$ & $82.2^{b}$ & 17.1 & 33.0 & 4.2 & 34.0 & 1.0 & 30.7 & 9.0 \\
\hline \multicolumn{9}{|c|}{ Radionuclides } \\
\hline $\mathrm{U}$ & $6.23^{b}$ & 1.54 & 3.79 & 0.50 & 3.31 & 0.35 & 3.30 & 0.46 \\
\hline${ }^{137} \mathrm{Cs}$ & $1.24^{b}$ & 0.48 & 0.28 & 0.29 & 0.43 & 0.17 & $<0.11$ & $\cdots$ \\
\hline${ }^{60} \mathrm{Co}$ & 0.25 & 0.10 & $<0.04$ & 0.02 & $<0.07$ & $\ldots$ & $<0.02$ & \\
\hline${ }^{40} \mathrm{~K}$ & 5.88 & 2.71 & 5.88 & 2.87 & 4.8 & 0.20 & 7.03 & 2.87 \\
\hline
\end{tabular}

${ }^{a}$ Data are mean and standard deviation (Std). Samples were taken in May 1988. Six samples were taken on the sludge treated site ( 2 each from plots at the top, middle and bottom of the slope), and 3 from the reference site ( 1 from each slope position). All samples were analysed, but because some values were below the detection limits, some of the reported means and standard deviations are derived from fewer samples. These values are denoted by " $<$ " and the number of values contributing to the means are as follows: Sludge-treated: $\mathrm{Cd}$ ( $\mathrm{n}=3$ at $0-15$ $\mathrm{cm}$ and $\mathrm{n}=2$ at $15-30 \mathrm{~cm})$, and $\mathrm{Ag}$ at $15-30 \mathrm{~cm}(\mathrm{n}=2)$. Where no std is given, all values were below detection limits. For the radionuclides listed separately, the number of means above the detection limits were 6 for sludge-treated, except for ${ }^{\circ} \mathrm{Co}$ at $15-30 \mathrm{~cm}(\mathrm{n}=3)$, and 3 for reference, except ${ }^{\circ 0} \mathrm{Co}(\mathrm{n}=1$ at $0-15 \mathrm{~cm}, \mathrm{n}=0$ at $15-30 \mathrm{~cm})$ and ${ }^{137} \mathrm{Cs}$ $(\mathrm{n}=1$ at $15-30 \mathrm{~cm})$. Units are $\mathrm{mg} / \mathrm{kg}$ for elements $\mathrm{Ag}$ through $\mathrm{U}$ and $\mathrm{pCi} / \mathrm{g}$ for the radioisotopes.

${ }^{b}$ Mean statistically different from that of the corresponding reference soil $(p=0.05)$. 
Table 4.4. Concentrations of metals and nitrogen at two depths in Pine Plantation soils on sludge-treated and reference (untreated) sites ${ }^{n}$

\begin{tabular}{|c|c|c|c|c|}
\hline \multirow[b]{2}{*}{ Element } & \multirow[b]{2}{*}{ Depth } & \multicolumn{2}{|c|}{$\begin{array}{c}\text { Concentration in soil, mg/kg } \\
\text { mean } \pm \text { std. dev. }\end{array}$} & \multirow{2}{*}{$\begin{array}{l}\text { Significance } \\
\text { probability }\end{array}$} \\
\hline & & Sludge-treated & Reference & \\
\hline $\mathrm{Ca}$ & $\begin{array}{l}0-15 \mathrm{~cm} \\
15-30 \mathrm{~cm}\end{array}$ & $\begin{array}{l}784 \pm 161 \\
529 \pm 106 \\
\end{array}$ & $\begin{array}{l}638 \pm 152 \\
420 \pm 186 \\
\end{array}$ & $\begin{array}{l}0.20 \\
0.22\end{array}$ \\
\hline $\mathrm{Cd}$ & $\begin{array}{l}0-15 \mathrm{~cm} \\
15-30 \mathrm{~cm}\end{array}$ & $\begin{array}{l}0.224 \pm 0.103 \\
0.040 \pm 0.025\end{array}$ & $\begin{array}{l}0.119 \pm 0.044 \\
0.027 \pm 0.012\end{array}$ & $\begin{array}{l}0.13 \\
0.41\end{array}$ \\
\hline $\mathrm{Cr}$ & $\begin{array}{l}0-15 \mathrm{~cm} \\
15-30 \mathrm{~cm}\end{array}$ & $\begin{array}{c}19.6 \pm 4.5 \\
21.0 \pm 10.0\end{array}$ & $\begin{array}{l}18.5 \pm 12.1 \\
13.1 \pm 4.7\end{array}$ & $\begin{array}{l}0.89 \\
0.22\end{array}$ \\
\hline $\mathrm{Cu}$ & $\begin{array}{l}0-15 \mathrm{~cm} \\
15-30 \mathrm{~cm} \\
\end{array}$ & $\begin{array}{r}16.6 \pm 2.0 \\
6.7 \pm 1.9 \\
\end{array}$ & $\begin{array}{l}6.2 \pm 3.9 \\
6.3 \pm 4.4 \\
\end{array}$ & $\begin{array}{r}<0.01 \\
0.85 \\
\end{array}$ \\
\hline $\mathrm{K}$ & $\begin{array}{l}0-15 \mathrm{~cm} \\
15-30 \mathrm{~cm}\end{array}$ & $\begin{array}{r}533 \pm 100 \\
565 \pm 138 \\
\end{array}$ & $\begin{array}{l}518 \pm 269 \\
522 \pm 232 \\
\end{array}$ & $\begin{array}{l}0.93 \\
0.70\end{array}$ \\
\hline $\mathbf{M g}$ & $\begin{array}{l}0-15 \mathrm{~cm} \\
15-30 \mathrm{~cm}\end{array}$ & $\begin{array}{r}689 \pm 91 \\
750 \pm 111 \\
\end{array}$ & $\begin{array}{l}632 \pm 295 \\
700 \pm 303 \\
\end{array}$ & $\begin{array}{l}0.78 \\
0.80\end{array}$ \\
\hline $\mathrm{Ni}$ & $\begin{array}{l}0-15 \mathrm{~cm} \\
15-30 \mathrm{~cm}\end{array}$ & $\begin{array}{l}8.67 \pm 1.12 \\
7.66 \pm 1.22 \\
\end{array}$ & $\begin{array}{l}8.00 \pm 5.29 \\
8.33 \pm 5.86 \\
\end{array}$ & $\begin{array}{l}0.85 \\
0.86\end{array}$ \\
\hline $\mathrm{Pb}$ & $\begin{array}{l}0-15 \mathrm{~cm} \\
15-30 \mathrm{~cm} \\
\end{array}$ & $\begin{array}{r}16.4 \pm 2.3 \\
9.1 \pm 2.3 \\
\end{array}$ & $\begin{array}{r}14.3 \pm 6.5 \\
9.0 \pm 7.6 \\
\end{array}$ & $\begin{array}{l}0.63 \\
0.98 \\
\end{array}$ \\
\hline $\mathrm{Zn}$ & $\begin{array}{l}0-15 \mathrm{~cm} \\
15-30 \mathrm{~cm}\end{array}$ & $\begin{array}{l}80.3 \pm 17.0 \\
43.9 \pm 13.8\end{array}$ & $\begin{array}{l}41.5 \pm 22.8 \\
33.7 \pm 14.4\end{array}$ & $\begin{array}{l}0.01 \\
0.30\end{array}$ \\
\hline $\mathrm{N}$ & $\begin{array}{l}0-15 \mathrm{~cm} \\
15-30 \mathrm{~cm}\end{array}$ & $\begin{array}{r}1810 \pm 280 \\
487 \pm 136 \\
\end{array}$ & $\begin{array}{r}1537 \pm 216 \\
553 \pm 270 \\
\end{array}$ & $\begin{array}{l}0.16 \\
0.57\end{array}$ \\
\hline As & $\begin{array}{l}0-15 \mathrm{~cm} \\
15-30 \mathrm{~cm}\end{array}$ & $\begin{array}{l}5.74 \pm 1.38 \\
5.30 \pm 1.53\end{array}$ & $\begin{array}{l}6.27 \pm 3.13 \\
4.59 \pm 2.92\end{array}$ & $\begin{array}{l}0.68 \\
0.58\end{array}$ \\
\hline $\mathrm{Hg}$. & $\begin{array}{l}0-15 \mathrm{~cm} \\
15-30 \mathrm{~cm} \\
30+\mathrm{cm}\end{array}$ & $\begin{array}{c}0.293 \pm 0.08 \\
0.074 \pm 0.019 \\
0.106 \pm 0.081\end{array}$ & $\begin{array}{c}0.092 \pm 0.010 \\
<0.056^{b} \\
0.067 \pm 0.017\end{array}$ & $\begin{array}{r}<0.01 \\
0.43\end{array}$ \\
\hline
\end{tabular}

${ }^{a}$ Soils were sampled 11/16/89, five months after sludge application ended. Metals were determined by Analytical Resources, Inc., Seattle, Washington, by ICP and AA TKN was determined by A\&L Agricultural Laboratories, Memphis, Tennessee. Arsenic and mercury (three depths for $\mathrm{Hg}$ ) were determined by the University of Georgia Soil Testing and Plant Analysis Laboratory. Sample size was $\mathbf{N}=3$ for reference soils, $\mathbf{N}=9$ for sludgetreated (mean from all three types of sludge application plots-see text). Probability $<0.05$ indicates a significant difference between concentrations in sludge-treated and reference soils.

${ }^{b}$ Two of three values below the detection limit of $0.04 \mathrm{mg} / \mathrm{kg}$, one value $0.056 \mathrm{mg} / \mathrm{kg}$.

In general, a comparison of sample and reference soils from each of the sites sampled indicates that sludge application may increase the concentrations of some metals in the upper $15 \mathrm{~cm}$ of the soil (Table $4.3,4.4,4.5$, and 4.6 ), but not usually significantly (at the $p=0.05$ level, with a sample size of 3 to 9). At the Pine Plantation Site, only $\mathrm{Cu}, \mathrm{Zn}$, and $\mathrm{Hg}$ (Table 4.4) and ${ }^{60} \mathrm{Co}$ and total $\mathrm{U}$ (Table 4.5 ) were significantly higher in the sludge-treated plots-again, only in the upper $15 \mathrm{~cm}$. Additional sectioning and radionuclide analysis of the 
Pine Plantation soil from samplings in July 1989 and May 1990 showed that elevated levels of ${ }^{137} \mathrm{Cs}$ were largely confined to the upper $2 \mathrm{~cm}$ initially, but that $U$ and ${ }^{60} \mathrm{Co}$ had moved into the 2-7 cm strata (Boston, et al., 1990). By May 1990 , the majority of the $\mathrm{U},{ }^{137} \mathrm{Cs}$, and ${ }^{60} \mathrm{Co}$ was still in the upper $7 \mathrm{~cm}$ of the soil, but there was some evidence of radionuclide movement into the $7-15 \mathrm{~cm}$ depth in individual soil cores, although average concentrations were not higher (Boston, et al., 1990).

The soil samples taken at the Cottonwood and Upper Hayfield 1 and 2 sites in January 1991 (see also Table 4.2), were also analyzed for metal concentrations (Table 4.6). As at the other sites, some metals were slightly higher in the sludge application areas. However, only $\mathrm{Cu}$ and $\mathrm{Zn}$ concentrations at the Scarboro site were significantly higher, and four metals were significantly lower in concentration at this site. Statistical comparisons were not done for Hayfields 1 and 2.

Radionuclides were also measured in soil samples taken from five sites in 1992 and 1993. Table 4.7 shows ${ }^{99} \mathrm{Tc},{ }^{90} \mathrm{Sr}$, and total uranium concentration in these soils, as the mean \pm the standard deviation. The levels tended to be slightly higher on the sludge-treated sites than on the reference sites, but in most cases only slightly higher. Mean $\mathrm{pCi} / \mathrm{g}$ of ${ }^{137} \mathrm{Cs}$ and ${ }^{60} \mathrm{Co}$ are shown in Table 4.8, along with the naturally occurring ${ }^{40} \mathrm{~K}$ The values for ${ }^{137} \mathrm{Cs}$ and ${ }^{40} \mathrm{~K}$ were similar on both the sludge treated and reference sites, in most cases. ${ }^{60} \mathrm{Co}$, although low on sludge-treated sites, was usually not detectable at all on the reference sites. The radiation from added ${ }^{60} \mathrm{Co}$ and ${ }^{137} \mathrm{Cs}$ is, in any case, much lower than the radiation from the naturally occurring $40 \mathrm{~K}$.

Radionuclides analyzed in soils from sludge application sites can also be compared to other nonapplication areas within Oak Ridge. Background soil characterization for the Oak Ridge Reservation has been reported in document DOE/OR/01-1175/V2, ESD Publication Number 4144, October 1993. Soil sections in $5 \mathrm{~cm}$ intervals from the surface to a depth of $30 \mathrm{~cm}$ were collected at various locations and analyzed for radionuclides. ${ }^{60} \mathrm{Co}$ was absent from these samples but fallout ${ }^{137} \mathrm{Cs}$, as well as natural radionuclides, were present. ${ }^{137} \mathrm{Cs}$ surface soil concentrations $(0-5 \mathrm{~cm})$ ranged from approximately 0.4 to $4 \mathrm{pCi} / \mathrm{g}$, and concentrations of ${ }^{238} \mathrm{U}$ and ${ }^{235} \mathrm{U}$ values in surface soils ranged from not detected to a high of nearly $11 \mathrm{pCi} / \mathrm{g}$ and $0.9 \mathrm{pCi} / \mathrm{g}$, respectively.

\subsection{Organics}

Analyses for organic contaminants in soil [i.e., pesticides; PCBs (EPA methods 8080/8081); and base, neutral, and acid compounds (EPA method 8270)], were performed on several occasions by Eckenfelder Inc., Nashville, Tennessee. In general, none of the organics tested for have been detected in the soils. An exception to this was in the soils collected on May 12, 1993, from the Scarboro (two samples) and Upper Hayfield No. 1 (two samples) sites (sites being actively used at that point) and nearby reference areas (two samples). Three of four samples from sludge-treated areas had detectable concentrations of pesticides: heptachlor epoxide (one sample, $4.9 \mathrm{mg} / \mathrm{kg}$ soil-MDL $2.5 \mathrm{mg} / \mathrm{kg}$ ); alpha-chlordane (one sample, $7.2 \mathrm{mg} / \mathrm{kg}-\mathrm{MDL} 2.5 \mathrm{mg} / \mathrm{kg}$ ); and gamma-chlordane (2 samples, 6.9 and $4.9 \mathrm{mg} / \mathrm{kg}-\mathrm{MDL}$ $2.5 \mathrm{mg} / \mathrm{kg}$ ). No other pesticides or semivolatile organic compounds were detected ( 96 compounds were analyzed for). Neither reference sample had detectable concentrations of any of the organics. 


\subsubsection{Summary}

In general, the application of Oak Ridge municipal sewage sludge on the Oak Ridge Reservation has slightly improved soil fertility ( $\mathrm{P}, \mathrm{N}$, etc.; see also Van Miegroet, et al., 1989), and has not had an adverse effect on the soils in terms of metals, organics, or radionuclide contamination. The metals tend to be rapidly immobilized and retained in the upper $15 \mathrm{~cm}$ of the soil (see also Van Migroet, et al., 1989), and those metals that are elevated in the treatment soils are not generally present at levels significantly above those found in other soils in the U.S. (Chang, et al., 1986).

Table 4.5. Radionuclides at three depths in Pine Plantation soils on sludge-treated and reference (untreated) sites

\begin{tabular}{|l|l|l|l|}
\hline \multirow{2}{*}{ Element } & & \multicolumn{2}{|c|}{$\begin{array}{c}\text { Concentration in soil, } \\
\text { Mean } \pm \text { Std. Dev. }\end{array}$} \\
\cline { 2 - 4 } & Depth & Sludge-treated & Reference \\
\hline${ }^{137} \mathrm{Cs}, \mathrm{pCi} / \mathrm{g}$ & $0-15 \mathrm{~cm}$ & $0.35 \pm 0.27$ & $0.43 \pm 0.02$ \\
& $15-30 \mathrm{~cm}$ & $0.041 \pm 0.013$ & $0.051 \pm 0.028$ \\
& $30+\mathrm{cm}$ & $\mathrm{ND}(<0.01)$ & $\mathrm{ND}(<0.05)$ \\
\hline${ }^{80} \mathrm{Co}, \mathrm{pCi} / \mathrm{g}$ & $0-15 \mathrm{~cm}$ & $0.093^{b} \pm 0.011$ & $\mathrm{ND}(<0.03)$ \\
& $15-30 \mathrm{~cm}$ & $\mathrm{ND}(<0.011)$ & $\mathrm{ND}(<0.012)$ \\
& $30+\mathrm{cm}$ & $\mathrm{ND}$ & $\mathrm{ND}$ \\
\hline${ }^{40} \mathrm{~K}, \mathrm{pCi} / \mathrm{g}$ & $0-15 \mathrm{~cm}$ & $3.19 \pm 0.56$ & $2.47 \pm 0.59$ \\
& $15-30 \mathrm{~cm}$ & $3.17 \pm 0.49$ & $3.17 \pm 1.15$ \\
& $30+\mathrm{cm}$ & $3.70 \pm 1.70$ & $3.83 \pm 1.00$ \\
\hline $\mathrm{U}, \mathrm{mg} / \mathrm{kg}$ & $0-15 \mathrm{~cm}$ & $7.90^{b} \pm 0.74$ & $3.81 \pm 0.86$ \\
& $15-30 \mathrm{~cm}$ & $3.55 \pm 0.45$ & $3.37 \pm 0.89$ \\
& $30+\mathrm{cm}$ & $1.05 \pm 1.48$ & $0.87 \pm 1.50$ \\
\hline
\end{tabular}

${ }^{\circ}$ Soils were sampled $11 / 16 / 89$, five months after sludge application ended. ${ }^{137} \mathrm{Cs},{ }^{60} \mathrm{Co}$, and naturally occurring ${ }^{40} \mathrm{~K}$, included for comparison, were determined by gamma emmission spectroscopy. Total $U$ was determined by Elbert Carlton, ORAU, by INAA (neutron activation method). Sample size was $\mathrm{N}=3$ for each soil, reference and sludge-only plots. ND indicates samples below detection limits-average detection limit noted in parentheses.

${ }^{b}$ Mean for sludge-treated soils was significantly different from reference soils (T-test, $\mathrm{p}<0.05$ ) (using the detection limit where the activity or concentration was below the detection limit). 
Table 4.6. Concentrations of metals in the upper $0-15 \mathrm{~cm}$ in soils at the Cottonwood, Scarboro, and Hayfield 1 \& 2 sites on sludge-treated and reference (untreated) areas ${ }^{a}$

\begin{tabular}{|c|c|c|c|c|c|c|}
\hline \multirow[b]{3}{*}{ Element } & \multicolumn{6}{|c|}{ Concentration in soil, ppm. (Mean \pm Std. Dev.) } \\
\hline & \multicolumn{2}{|c|}{ Cottonwoods } & \multicolumn{2}{|c|}{ Scarboro } & \multirow{2}{*}{$\begin{array}{l}\text { Hayfield } 1 \\
\begin{array}{l}\text { Sludge- } \\
\text { treated }\end{array}\end{array}$} & \multirow{2}{*}{$\begin{array}{l}\text { Hayfield } 2 \\
\begin{array}{l}\text { Sludge- } \\
\text { treated }\end{array}\end{array}$} \\
\hline & $\begin{array}{l}\text { Sludge- } \\
\text { treated }\end{array}$ & Reference & $\begin{array}{l}\text { Sludge- } \\
\text { treated }\end{array}$ & Reference & & \\
\hline $\mathrm{Ca}$ & $\begin{array}{r}1897 \\
\pm 886 \\
\end{array}$ & $\begin{array}{r}956 \\
\pm \quad 91 \\
\end{array}$ & $\begin{array}{r}1190 \\
+\quad 118 \\
\end{array}$ & $\begin{array}{r}1300 \\
\pm 155 \\
\end{array}$ & $\begin{array}{r}1250 \\
\pm 182 \\
\end{array}$ & $\begin{array}{c}1657 \\
\pm 150 \\
\end{array}$ \\
\hline $\mathrm{Cd}$ & $\begin{array}{c}0.502 \\
+0.251 \\
\end{array}$ & $\begin{array}{c}0.085 \\
\pm 0.007 \\
\end{array}$ & $\begin{array}{c}0.272 \\
\pm \quad 0.072 \\
\end{array}$ & $\begin{array}{c}0.173 \\
\pm 0.032 \\
\end{array}$ & $\begin{array}{c}0.240 \\
\pm 0.060 \\
\end{array}$ & $\begin{array}{c}0.259 \\
\pm 0.022 \\
\end{array}$ \\
\hline $\mathrm{Cr}$ & $\begin{array}{c}35.1 \\
\pm 15.0 \\
\end{array}$ & $\begin{array}{r}36.7 \\
\pm \quad 6.6 \\
\end{array}$ & $\begin{array}{l}29.3 \\
\pm 11.2 \\
\end{array}$ & $\begin{array}{r}21.0 \\
\pm 3.3 \\
\end{array}$ & $\begin{array}{l}32.0 \\
\pm 7.9 \\
\end{array}$ & $\begin{array}{c}22.6 \\
\pm 0.9 \\
\end{array}$ \\
\hline $\mathrm{Cu}$ & $\begin{array}{c}48.9 \\
\pm \quad 24.0 \\
\end{array}$ & $\begin{array}{c}11.4 \\
\pm 3.7 \\
\end{array}$ & $\begin{array}{r}11.6^{b} \\
\pm 1.2 \\
\end{array}$ & $\begin{array}{r}7.0 \\
\pm 0.1 \\
\end{array}$ & $\begin{array}{r}15.1 \\
\pm 7.4 \\
\end{array}$ & $\begin{array}{r}10.8 \\
\pm 1.5 \\
\end{array}$ \\
\hline $\mathrm{K}$ & $\begin{array}{c}972 \\
\pm 551 \\
\end{array}$ & $\begin{array}{r}789 \\
\pm 23 \\
\end{array}$ & $\begin{array}{r}450^{b} \\
\pm 61 \\
\end{array}$ & $\begin{array}{r}855 \\
\pm \quad 16 \\
\end{array}$ & $\begin{array}{r}889 \\
\pm \quad 384 \\
\end{array}$ & $\begin{array}{r}680 \\
\pm 548 \\
\end{array}$ \\
\hline $\mathrm{Mg}$ & $\begin{array}{r}1213 \\
+929 \\
\end{array}$ & $\begin{array}{r}841 \\
\pm 107 \\
\end{array}$ & $\begin{array}{r}554^{b} \\
\pm 61 \\
\end{array}$ & $\begin{array}{r}922 \\
+\quad 23 \\
\end{array}$ & $\begin{array}{r}746 \\
\pm 106 \\
\end{array}$ & $\begin{array}{r}1093 \\
\pm 45 \\
\end{array}$ \\
\hline $\mathrm{Ni}$ & $\begin{array}{r}18.7 \\
\pm \quad 4.7 \\
\end{array}$ & $\begin{array}{r}14.5 \\
\pm 2.1 \\
\end{array}$ & $\begin{array}{r}6.0^{b} \\
\pm 1.7 \\
\end{array}$ & $\begin{array}{r}12.0 \\
+\quad 14 \\
\end{array}$ & $\begin{array}{r}8.7 \\
\pm 0.6 \\
\end{array}$ & $\begin{array}{c}14.0 \\
\pm 1.0 \\
\end{array}$ \\
\hline $\mathrm{Pb}$ & $\begin{array}{r}47.7 \\
\pm 3.1 \\
\end{array}$ & $\begin{array}{r}45.5 \\
\pm 7.8 \\
\end{array}$ & $\begin{array}{r}20.0 b \\
\pm 1.0 \\
\end{array}$ & $\begin{array}{r}31.5 \\
\pm \quad 2.1 \\
\end{array}$ & $\begin{array}{r}23.7 \\
\pm 3.5 \\
\end{array}$ & $\begin{array}{c}30.0 \\
\pm 5.3\end{array}$ \\
\hline $\mathrm{Zn}$ & $\begin{array}{c}177.7 \\
\pm 59.7\end{array}$ & $\begin{array}{c}67.3 \\
\pm 16.4\end{array}$ & $\begin{array}{r}64.9^{b} \\
\pm \quad 6.9\end{array}$ & $\begin{array}{c}44.7 \\
\pm 3.1\end{array}$ & $\begin{array}{c}74.4 \\
+24.8\end{array}$ & $\begin{array}{c}63.6 \\
\pm 3.9\end{array}$ \\
\hline
\end{tabular}

aSoils were sampled 1/17/90. Metals were determined by Analytical Resources, Inc., Seattle, Washington, by ICP and graphite furnace AA (cadmium). Sample size was 2 for reference soils, 3 for sludge-treated. The reference soils for the Scarboro site may also be taken as representative reference soils for the two hayfield sites.

${ }^{b}$ Mean metal concentration in sludge-treated soils was statistically different from the mean in the corresponding reference soil $(p=0.05)$. (Note that for some metals the means were significantly lower in the sludge-treated soils.) 
Table 4.7. Mean ${ }^{9} \mathrm{Tc},{ }^{9} \mathrm{Sr}$, and total uranium in soils in sludge application areas (4 grassy fields and one wooded area) and associated reference areas

\begin{tabular}{|l|l|l|l|l|l|l|}
\hline \multirow{2}{*}{} & \multicolumn{2}{|c|}{ 9T/, Bq/kg } & \multicolumn{2}{c|}{ 90 Sr, Bq/kg } & \multicolumn{2}{c|}{ U, ppm } \\
\cline { 2 - 7 } & $\begin{array}{l}\text { Sludge- } \\
\text { treated }\end{array}$ & Reference & $\begin{array}{l}\text { Studge- } \\
\text { treated }\end{array}$ & Reference & $\begin{array}{l}\text { Sludge- } \\
\text { treated }\end{array}$ & Reference \\
\hline $\begin{array}{l}\text { Rogers High } \\
\text { Pasture }\end{array}$ & $\begin{array}{l}3.0 \pm 0.8 \\
(\mathrm{n}=3)\end{array}$ & $\begin{array}{l}1.5 \\
(\mathrm{n}=1)\end{array}$ & $\begin{array}{l}5.2 \pm 2.7 \\
(\mathrm{n}=3)\end{array}$ & $\begin{array}{l}4.3 \pm 2.3 \\
(\mathrm{n}=3)\end{array}$ & $\begin{array}{l}4.9 \pm 0.2 \\
(\mathrm{n}=3)\end{array}$ & $\begin{array}{l}3.3 \pm 0.3 \\
(\mathrm{n}=3)\end{array}$ \\
\hline Scarboro & $\begin{array}{l}1.5 \pm 1.0 \\
(\mathrm{n}=3)\end{array}$ & $\begin{array}{l}\mathrm{ND} \\
(\mathrm{n}=1)\end{array}$ & $\begin{array}{l}6.1 \pm 1.0 \\
(\mathrm{n}=3)\end{array}$ & $\begin{array}{l}6.7 \pm 2.2 \\
(\mathrm{n}=3)\end{array}$ & $\begin{array}{l}4.6 \pm 0.8 \\
(\mathrm{n}=3)\end{array}$ & $\begin{array}{l}3.5 \pm 0.3 \\
(\mathrm{n}=3)\end{array}$ \\
\hline $\begin{array}{l}\text { Upper } \\
\text { Hayfield }\end{array}$ & $\begin{array}{l}0.5 \pm 0.44 \\
(\mathrm{n}=3)\end{array}$ & $\begin{array}{l}0.3 \\
(\mathrm{n}=1)\end{array}$ & $\begin{array}{l}4.4 \pm 2.7 \\
(\mathrm{n}=3)\end{array}$ & $\begin{array}{l}2.7 \pm 1.3 \\
(\mathrm{n}=3)\end{array}$ & $\begin{array}{l}5.2 \pm 1.0 \\
(\mathrm{n}=3)\end{array}$ & $\begin{array}{l}4.1 \pm 0.6 \\
(\mathrm{n}=3)\end{array}$ \\
\hline $\begin{array}{l}\text { Upper } \\
\text { Hayfield \#2 }\end{array}$ & $\begin{array}{l}2.0 \pm 0.4 \\
(\mathrm{n}=3)\end{array}$ & $\begin{array}{l}7.1 \pm 4.6 \\
(\mathrm{n}=3)\end{array}$ & $\begin{array}{l}4.6 \pm 1.0 \\
(\mathrm{n}=3)\end{array}$ & \\
\hline Watson Road & $\begin{array}{l}3.3 \pm 2.2 \\
(\mathrm{n}=5)\end{array}$ & $\begin{array}{l}2.3 \\
(\mathrm{n}=1)\end{array}$ & $\begin{array}{l}6.3 \pm 3.5 \\
(\mathrm{n}=5)\end{array}$ & $\begin{array}{l}5.6 \pm 2.3 \\
(\mathrm{n}=3)\end{array}$ & $\begin{array}{l}4.1 \pm 0.9 \\
(\mathrm{n}=5)\end{array}$ & $\begin{array}{l}4.3 \pm 1.2 \\
(\mathrm{n}=3)\end{array}$ \\
\hline
\end{tabular}

${ }^{2}$ Samples were taken in May 1992, September 1992, and May 1993. Determinations of ${ }^{\circ} \mathrm{Tc}$ and ${ }^{90} \mathrm{Sr}$ were performed by Analytical Chemistry Division, ORNL. Total uranium was determined by neutron activation by Elbert Carlton of ORAU. Data are mean \pm standard deviation; sample numbers are in parentheses. The reference values for the first three sites may be taken as representative references for the Upper Hayfield site as well.

Table 4.8. Radionuclides in soils in sludge application areas (4 grassy fields and one wooded area) and associated reference areas

\begin{tabular}{|l|l|l|l|l|l|l|}
\hline & \multicolumn{3}{|l|}{${ }^{137} \mathrm{Cs}, \mathrm{pC} / \mathrm{g}$} & \multicolumn{2}{l|}{$\mathrm{C} \mathrm{Co}, \mathrm{pC} / \mathrm{g}$} & \multicolumn{2}{l|}{${ }^{40 \mathrm{~K}, \mathrm{pC} / \mathrm{g}}$} \\
\hline & $\begin{array}{l}\text { Sludge- } \\
\text { treated }\end{array}$ & Reference & $\begin{array}{l}\text { Sludge- } \\
\text { treated }\end{array}$ & Reference & $\begin{array}{l}\text { Sludge- } \\
\text { treated }\end{array}$ & Reference \\
\hline $\begin{array}{l}\text { Rogers High } \\
\text { Pasture }\end{array}$ & $0.45 \pm 0.63$ & $0.47 \pm 0.06$ & $0.06 \pm 0.059$ & $\mathrm{ND}$ & $4.14 \pm 0.87$ & $3.13 \pm 0.53$ \\
\hline Scarboro & $0.81 \pm 0.28$ & $0.48 \pm 0.11$ & $0.03 \pm 0.03$ & $\mathrm{ND}$ & $3.78 \pm 1.51$ & $3.97 \pm 1.04$ \\
\hline $\begin{array}{l}\text { Upper } \\
\text { Hayfield }\end{array}$ & $0.57 \pm 0.15$ & $0.54 \pm 0.08$ & $0.05 \pm 0.02$ & $0.01 \pm 0.01$ & $2.68 \pm 0.20$ & $3.04 \pm 0.41$ \\
\hline $\begin{array}{l}\text { Upper } \\
\text { Hayfield \#2 }\end{array}$ & $0.77 \pm 0.05$ & & $0.01 \pm 0.03$ & & $4.80 \pm 1.97$ & \\
\hline Watson Road & $0.59 \pm 0.19$ & $0.54 \pm 0.15$ & $0.01 \pm 0.02$ & ND & $7.45 \pm 1.24$ & $11.2 \pm 1.70$ \\
\hline
\end{tabular}

aSamples were taken in May 1992, September 1992, and May 1993. Determinations were performed by I. L. Larsen, Environmental Sciences Division, ORNL. Data are means \pm standard deviations. ND indicates that indicate that ${ }^{\circ} \mathrm{Co}$ was not detected in any of the samples for that site, with detection limits which varied from 0.005 to 0.012 depending on counting time. Values below detection limits were treated as zeros when calculating mean and standard deviations (only the Upper Hayfield sludge-treated sites had detectable ${ }^{\infty} \mathrm{Co}$ in all samples). Uranium was only detected in one sample, from the sludge-treated area of the Scarboro site $\left(0.14 \pm 0.06 \mathrm{pCi} / \mathrm{g}\right.$ of ${ }^{235} \mathrm{U}$, and 2.2 $\pm 1.0 \mathrm{pCi} / \mathrm{g}$ of ${ }^{238} \mathrm{U}$ ). Sample number $n=3$, except $n=5$ for Watson Road, sludge-treated area (sampled in both 1992 and 1993). The reference values for the first three sites may be taken as representative references for the Upper Hayfield site as well. 


\section{VEGETATION}

\subsection{METHODS OF SAMPLING AND ANALYSIS}

In order to address the issue of constituents from sludge entering the food chain, vegetation samples were taken from several sludge application sites between 1988 and 1990 . Samples were taken after and, in some cases, also before sludge application. These samples were analyzed for uptake of metals and radionuclides from the soil. Samples of grasses were taken from the Rogers and Hayfield sites, and extensive sampling was done on the Pine Plantation Site, including weeds (vegetative parts of the herbaceous understory, predominantly grasses) and berries (primarily blackberries from bushes growing in the understory), as well as needles from the pine trees. Vegetation was clipped from a $1 \mathrm{~m}^{2}$ area, rinsed with distilled water to remove caked sludge, and dried. Needle samples were obtained from branches snapped off along a transect at mid-crown level and included needles from all age classes.

Analyses of metals were by ICP, with some additional analyses for cadmium by graphite furnace AA to improve detection limits. Nitrogen and ICP analyses were done by either ORNL Analytical Chemistry Division; A\&L Agricultural Laboratory, Memphis, Tennessee; or Analytical Resources, Inc., in Seattle, Washington. Total uranium was measured by Elbert Carlton, ORAU, using the neutron activation method. Radionuclides were measured by I. L. Larsen, ORNL ESD, using gamma ray spectrometry.

\subsection{RESULTS}

Tables 5.1 through 5.3 present the data on concentrations of metals, nitrogen, and other analytes in vegetation growing on several sludge sites and their reference areas. Concentrations in herbaceous vegetation growing on the Rogers and Hayfield sites, as well as in the weedy understory beneath the Pine Plantation Site (Table 5.1, A-C), are indicative of the metals that would be available to grazing animals, although only wild animals have access to the sites in the land application program. Table 5.2 shows the concentrations found in pine needles at the Pine Plantation Site on three sampling dates: during sludge application, one month after application ended, and one year later. Table 5.3 shows the concentrations in blackberry fruits growing on bushes in the understory of the Pine Plantation (and thus theoretically available directly to humans or animals) one year after application ended. For the Rogers Site, during actual sludge application, concentrations were somewhat higher on treated sites than on reference sites for several plant nutrients, such as $\mathrm{N}, \mathrm{P}, \mathrm{K}, \mathrm{Ca}, \mathrm{Mg}$, and $\mathrm{Fe}$ (Table 5.1 A). Concentrations of $\mathrm{Ag}, \mathrm{Cu}, \mathrm{Na}, \mathrm{Pb}$, and $\mathrm{Zn}$ were also higher. (No statistical comparisons were performed). Higher concentrations during or immediately after active application periods, however, when sampling was not restricted to postapplication growth, could reflect either uptake of soluble forms of the analytes, or sample contamination by sludge clinging to leaf surfaces despite rinsing. This is also true of the weeds under the Pine Plantation (Table 5.1 C) during application, and even one month after application, when concentrations of $\mathrm{Al}, \mathrm{Ca}, \mathrm{Cu}, \mathrm{Fe}, \mathrm{Mg}, \mathrm{N}, \mathrm{P}, \mathrm{S}$, and $\mathrm{Zn}$ appeared to be substantially higher in treated vegetation. At the same time, biomass of the weedy understory vegetation in the Pine Plantation was substantially higher in the sludge application plots during the application period, (Fig. 5.1) probably reflecting higher availability of the nutrients found in sludge. Postapplication sampling of weeds and grasses (Table 5.1, A and B) showed fewer differences 
in nutrient or metals concentration in foliage, with slightly elevated levels of $\mathrm{Ca}$ and $\mathrm{P}$ at the Rogers Site two years post-treatment (Table 5.1, A) and higher $\mathrm{Cu}, \mathrm{Mg}, \mathrm{Mn} \mathrm{P,} \mathrm{Zn}$ at the Hayfield Site (Table 5.1 B) five months after application ended. Some differences in concentrations at the reference sites (e.g., of $\mathrm{Al}$ or $\mathrm{Cu}$ ) between sampling periods may reflect a difference in analytical laboratories.

Concentrations in pine needles of some metals-notably $\mathrm{Al}, \mathrm{Cu}, \mathrm{Fe}$, and $\mathrm{Na}$-appeared higher during sludge application, but these differences decreased one month post-treatment and were generally gone one year later, suggesting that no sustained uptake of these metals from the soil by pines occurred (Table 5.2). Concentrations of $\mathrm{Mn}$ and $\mathrm{Zn}$ remained elevated in pine needles, however, after the application period ended.

Metal uptake and translocation into berries was minimal, based on samples taken one year post-treatment (Table 5.3). Concentrations of $\mathrm{Co}, \mathrm{Mn}, \mathrm{Ni}$, and $\mathrm{Zn}$, however, were apparently elevated in berries from the sludge-treated site.

Radionuclides, in $\mathrm{pCi} / \mathrm{kg}$, were also measured in grasses and in pine needles (Table 5.4). Statistical analyses were not performed, but grass at the Rogers and Hayfield sites appeared to be slightly enriched in ${ }^{137} \mathrm{Cs}$ and the naturally occurring ${ }^{40} \mathrm{~K}$, particularly just as application ended, and slightly enriched in $U$ two years after application at the Rogers Site. New growth pine needles one year after application ended were slightly higher in ${ }^{137} \mathrm{Cs},{ }^{60} \mathrm{Co}$, and $U$ than were needles on the reference plots. Many radionuclides, particularly ${ }^{60} \mathrm{Co}$, were present below the detection limits in samples from both sludge and reference sites. 


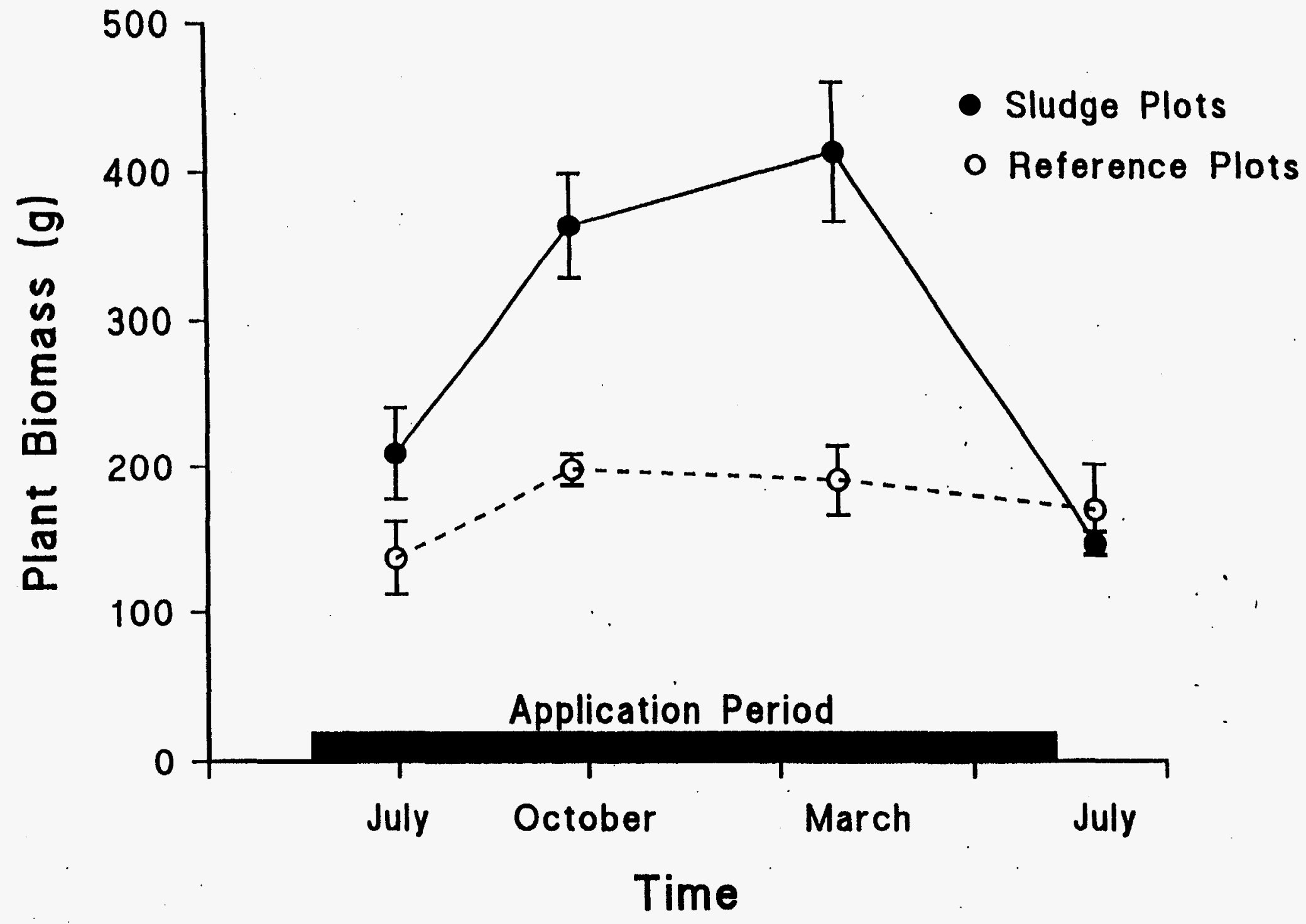

Fig. 5.1. Response of herbaceous plants to sludge application. Mass of plants growing in the understory of a young pine plantation on the Oak Ridge Reservation. Samples were dried and weighed. The black bar indicates the sludge application period, from June 10, 1998, to June 30,1989 . Values indicated are $\mathrm{g} / \mathrm{m}^{2}$, mean \pm standard error for nine samples per treatment. 
Table 5.1. Concentrations of metals and nitrogen in herbaceous vegetation (grasses and weeds) from three sludge application sites and reference areas (units are $\mathrm{mg} / \mathrm{kg}$ )

(a). Rogers Site (dates of application: 12/86-5/88

\begin{tabular}{|c|c|c|c|c|}
\hline & \multicolumn{2}{|c|}{$\begin{array}{l}\text { During application } \\
\text { (Spring 1988) }\end{array}$} & \multicolumn{2}{|c|}{$\begin{array}{c}\text { 2-years post-treatment } \\
\text { (May 3, 1990) }\end{array}$} \\
\hline & Reference & Treatment & Reference & Treatment \\
\hline Ag & $<0.12$ & 0.44 & & \\
\hline $\mathrm{Al}$ & 91.21 & 110.72 & 25 & 14.7 \\
\hline As & $<1.1$ & $<0.83$ & $<0.82$ & $<0.83$ \\
\hline B & 11.29 & 11.55 & 3.5 & 2.4 \\
\hline $\mathrm{Ca}$ & 3200 & 5000 & 3800 & 4700 \\
\hline $\mathrm{Cd}$ & $<0.14$ & $<1.00$ & $<0.082$ & $<.083$ \\
\hline Co & $<0.098$ & $<0.075$ & & \\
\hline $\mathrm{Cr}$ & 0.83 & 1.32 & 0.32 & 0.52 \\
\hline $\mathrm{Cu}$ & 15.33 & 39.58 & 6.0 & 6.6 \\
\hline $\mathrm{Fe}$ & 103.50 & 155.97 & 50 & 48 \\
\hline $\mathbf{K}$ & 15000 & 29000 & & \\
\hline $\mathrm{Mg}$ & 1600 & 2600 & 2000 & 1400 \\
\hline $\mathrm{Mn}$ & 82.27 & 82.42 & 98 & 41 \\
\hline Mo & $<.66$ & $<.66$ & $<0.65$ & $<0.66$ \\
\hline $\mathrm{N}$ & 14000 & 23600 & & \\
\hline $\mathrm{Na}$ & 64.32 & 455.93 & $<82$ & $<83$ \\
\hline $\mathrm{Ni}$ & 0.46 & 0.81 & 0.27 & 0.40 \\
\hline $\mathbf{P}$ & 1600 & 3100 & 2300 & 4033 \\
\hline $\mathrm{Pb}$ & 0.96 & 1.38 & $<0.82$ & $<0.83$ \\
\hline Se & $<.82$ & $<.83$ & $<0.82$ & $<0.83$ \\
\hline $\mathrm{U}$ & 0.13 & 0.68 & $<0.01$ & $<0.02$ \\
\hline $\mathrm{Zn}$ & 21.63 & 48.87 & 22 & 28.7 \\
\hline
\end{tabular}

(b). Hayfield Site (application dates: 1/89-12/89)

Post-treatment

(May 3, 1990)

\begin{tabular}{lcc} 
& Reference area & Treatment area \\
\hline Al & 37 & 44 \\
$\mathrm{As}$ & $<0.82$ & $<0.83$ \\
$\mathrm{~B}$ & 2.9 & 3.5 \\
$\mathrm{Ca}$ & 5450 & 5400 \\
$\mathrm{Cd}$ & $<0.082$ & $<0.083$ \\
$\mathrm{Cr}$ & 0.43 & 0.46 \\
$\mathrm{Cu}$ & 4.4 & 7.1 \\
$\mathrm{Fe}$ & 58 & 70 \\
$\mathrm{Mg}$ & 1700 & 2275 \\
$\mathrm{Mn}$ & 25.5 & 72.5 \\
$\mathrm{Mo}$ & $<0.66$ & $<0.66$ \\
$\mathrm{Na}$ & $<0.82$ & $<117$ \\
$\mathrm{Ni}$ & 0.31 & 0.38 \\
$\mathrm{P}$ & 3100 & 4025 \\
$\mathrm{~Pb}$ & $<0.82$ & $<0.83$ \\
$\mathrm{Se}$ & $<0.81$ & $<0.83$ \\
$\mathrm{U}$ & $<0.01$ & 0.05 \\
$\mathrm{Zn}$ & 16 & 27
\end{tabular}


Table 5.1 (continued)

(c). Pine Plantation-understony vegetaton (weeds), predominantly grasses (application dates: 6/88-6/89)

\begin{tabular}{lrrrr}
\hline & \multicolumn{2}{c}{$\begin{array}{c}\text { During application } \\
\text { (July 1988-May 1989) }\end{array}$} & $\begin{array}{c}\text { One month post-treatment } \\
\text { (July 17, 1989) }\end{array}$ \\
\cline { 2 - 5 } & Reference & Treatment & Reference & Treatment \\
\hline $\mathrm{Al}$ & 1557 & 4675 & 960 & 1830 \\
$\mathrm{~B}$ & 19 & 40 & 17 & 22 \\
$\mathrm{Ca}$ & 7280 & 20750 & 6700 & 9800 \\
$\mathrm{Cu}$ & 17 & 336 & 9 & 109 \\
$\mathrm{Fe}$ & 1650 & 8376 & 1343 & 2571 \\
$\mathrm{~K}$ & 7480 & 8200 & 10500 & 13800 \\
$\mathrm{Mg}$ & 1800 & 3790 & 1900 & 2700 \\
$\mathrm{Mn}$ & 300 & 446 & 409 & 960 \\
$\mathrm{~N}$ & 11800 & 27700 & 14600 & 29300 \\
$\mathrm{Na}$ & 300 & 500 & 100 & 300 \\
$\mathrm{P}$ & 1460 & 13500 & 1800 & 6400 \\
$\mathrm{~S}$ & 900 & 4180 & 1000 & 2200 \\
$\mathrm{Zn}$ & 43 & 995 & 42 & 392 \\
\hline
\end{tabular}

Table 5.2 Concentrations of ICP analytes, including metals, and nitrogen in pine needles from sludge application and reference plots in the Pine Plantation

(application dates: 6/88-6/89) (units are $\mathrm{mg} / \mathrm{kg}$ )

\begin{tabular}{|c|c|c|c|c|c|c|}
\hline & \multicolumn{2}{|c|}{$\begin{array}{l}\text { During application } \\
\text { (July 1988-May 1989) }\end{array}$} & \multicolumn{2}{|c|}{$\begin{array}{l}\text { One month post-treatment } \\
\text { (July 17, 1989) }\end{array}$} & \multicolumn{2}{|c|}{$\begin{array}{l}\text { One year post-treatment } \\
\text { (May 15, 1990) }\end{array}$} \\
\hline & $\begin{array}{l}\text { Reference } \\
\text { area }\end{array}$ & $\begin{array}{l}\text { Treatment } \\
\text { area }\end{array}$ & $\begin{array}{l}\text { Reference } \\
\text { area }\end{array}$ & $\begin{array}{l}\text { Treatment } \\
\text { area }\end{array}$ & $\begin{array}{l}\text { Reference } \\
\text { area }\end{array}$ & $\begin{array}{l}\text { Treatment } \\
\text { area }\end{array}$ \\
\hline Al & 430.00 & 1065.83 & 366.67 & 483.33 & 410 & 170 \\
\hline As & & & & & $<0.83$ & $<0.82$ \\
\hline B & 17.33 & 25.28 & 17.00 & 21.89 & 10.3 & 18.83 \\
\hline $\mathrm{Ca}$ & 3100 & 4700 & 3400 & 3700 & 3775 & 4150 \\
\hline $\mathrm{Cd}$ & & & & & 0.26 & 0.57 \\
\hline $\mathrm{Cr}$ & & & & & 0.28 & 0.34 \\
\hline $\mathrm{Cu}$ & 7.33 & 41.86 & 9.33 & 16.33 & 3.98 & 4.20 \\
\hline $\mathrm{Fe}$ & 235.08 & 980.58 & 125.67 & 375.00 & 43 & 54 \\
\hline $\mathbf{K}$ & 7700 & 8200 & 7900 & 8100 & & \\
\hline $\mathrm{Mg}$ & 1100 & 1400 & 1100 & 1100 & 1080 & 1008 \\
\hline Mn & 306.42 & 333.64 & 264.33 & 529.00 & 532.5 & 1192 \\
\hline Mo & & & & & $<0.66$ & $<0.66$ \\
\hline $\mathbf{N}$ & 14800 & 20700 & 14100 & 18600 & & \\
\hline $\mathrm{Na}$ & 100 & 300 & 100 & 100 & $<83$ & $<82$ \\
\hline $\mathrm{Ni}$ & & & & & 0.54 & 1.34 \\
\hline P & 1800 & 2900 & 700 & 1800 & 1275 & 1500 \\
\hline $\mathrm{Pb}$ & & & & & $<0.83$ & $<0.82$ \\
\hline$S$ & 600 & 900 & 500 & 600 & & \\
\hline $\mathrm{Se}$ & & & & & $<0.83$ & $<0.9$ \\
\hline $\mathbf{U}$ & & & & & 0.03 & 0.11 \\
\hline $\mathrm{Zn}$ & 48.25 & 172.89 & 51.33 & 87.11 & 47.75 & 105 \\
\hline
\end{tabular}


Table 5.3. Concentrations of ICP analytes and nitrogen in berries from the Pine Plantation (dates of application: 6/88-6/89) ${ }^{a}$

\begin{tabular}{|c|c|c|c|}
\hline & \multicolumn{2}{|c|}{ One year post-treatment (June 1990) } & \multirow[b]{2}{*}{$\begin{array}{r}\text { Detection limits } \\
\text { (if some }<\text { limit) }\end{array}$} \\
\hline & $\begin{array}{l}\text { Reference area } \\
\quad(n=3)\end{array}$ & $\begin{array}{l}\text { Treatment area } \\
\quad(n=3)\end{array}$ & \\
\hline Ag & $<0.09^{2}$ & $<0.33^{1}$ & 0.083 \\
\hline $\mathrm{Al}$ & $49.0 \pm 38$ & $22.0 \pm 5.2$ & \\
\hline As & $1.90 \pm 1.1$ & $1.57 \pm 0.4$ & \\
\hline B & $23.0 \pm 18$ & $20.0 \pm 1.7$ & \\
\hline $\mathrm{Ba}$ & $16.0+5.0$ & $12.5 \pm 6.9$ & \\
\hline $\mathrm{Be}$ & $<0.007^{1}$ & $<0.02^{\circ}$ & $0.005-0.053$ \\
\hline $\mathrm{Ca}$ & $2283 \pm 752$ & $2433 \pm 945$ & \\
\hline $\mathrm{Cd}$ & $<0.07^{1}$ & $0.16 \pm 0.015$ & \\
\hline $\mathrm{Co}$ & $<0.42^{2} \pm 0.007$ & $3.24 \pm 3.9$ & 0.064 \\
\hline $\mathrm{Cr}$ & $0.44 \pm 0.31$ & $0.21 \pm 0.02$ & \\
\hline $\mathrm{Cu}$ & $12.0 \pm 4.0$ & $7.13 \pm 3.4$ & \\
\hline $\mathrm{Fe}$ & $48.0 \pm 36.4$ & $62.3 \pm 58.6$ & \\
\hline $\mathrm{Li}$ & $<250^{\circ}$ & $<250^{\circ}$ & $240-250$ \\
\hline $\mathrm{Mg}$ & $2967 \pm 2454$ & $1833 \pm 208$ & \\
\hline $\mathrm{Mn}$ & $43 \pm 26$ & $270 \pm 70$ & \\
\hline Mo & $<0.50^{1}$ & $<0.66^{\circ}$ & $0.17-0.66$ \\
\hline $\mathrm{Na}$ & $<81.00^{1}$ & $<0.83^{\circ}$ & 0.83 \\
\hline $\mathrm{Ni}$ & $0.44 \pm 0.16$ & $4.32 \pm 5.79$ & \\
\hline$P$ & $1867 \pm 666$ & $2600 \pm 265$ & \\
\hline $\mathrm{Pb}$ & $<5.00^{1}$ & $<0.83^{\circ}$ & 0.83 \\
\hline $\mathrm{Sb}$ & $<0.82^{\circ}$ & $<0.82^{0}$ & \\
\hline $\mathrm{Se}$ & $<0.82^{0}$ & $<28.00^{\circ}$ & $0.8-83$ \\
\hline $\mathrm{Si}$ & $6.00 \pm 4.36$ & $<4.50^{2}$ & 3.3 \\
\hline $\mathrm{Sn}$ & $<0.82^{\circ}$ & $<28^{0}$ & $0.8-83$ \\
\hline $\mathrm{Sr}$ & $37.6 \pm 54$ & $6.5 \pm 2.59$ & \\
\hline $\mathrm{Ti}$ & $<0.49^{1}$ & $<0.33^{\circ}$ & 0.33 \\
\hline $\mathrm{V}$ & $<0.10^{1}$ & $<0.033^{\circ}$ & 0.033 \\
\hline $\mathrm{Zn}$ & $19.0 \pm 8.5)$ & $26.0 \pm 5.0$ & \\
\hline$\overline{Z r}$ & $<0.33^{\circ}$ & $<0.33^{\circ}$ & 0.33 \\
\hline
\end{tabular}

${ }^{a}$ Means ( \pm std) for each element are reported for reference and treatment plots. When one or more values were below the detection limit, then the mean is given as " $<x<x$," indicating the maximum possible mean-that is, assuming that the values less than the detection limit were in fact equal to the detection limit. Superscripts indicate the number of values greater than the detection limit of the measurement. The range of reported detection limits is listed in the next column. Only Mn concentrations were significantly different in berries from the treatment and reference sites $(p<0.01)$. 
Table 5.4. Radionuclides in vegetation on sludge application and reference areas (dry weight basis) ${ }^{a}$

\begin{tabular}{|c|c|c|c|}
\hline & Radionuclides & Sludge-treated & Reference \\
\hline \multirow[t]{6}{*}{ Grasses } & \multicolumn{3}{|c|}{ Rogers Site, sampling date: 1988 (at the end of application) } \\
\hline & $\begin{array}{l}{ }^{137} \mathrm{Cs}(\mathrm{pCi} / \mathrm{kg}) \\
{ }^{60} \mathrm{Co}(\mathrm{pCi} / \mathrm{kg}) \\
{ }^{40} \mathrm{~K}(\mathrm{pCi} / \mathrm{kg}) \\
{ }^{7} \mathrm{Be}(\mathrm{pCi} / \mathrm{kg})\end{array}$ & $\begin{array}{c}61 \pm 52 \\
{[59-<200]} \\
27400 \pm 5800 \\
5360 \pm 2930\end{array}$ & $\begin{array}{c}{[61-<200]} \\
<86 \\
18900 \pm 4420 \\
13800 \pm 8200\end{array}$ \\
\hline & \multicolumn{3}{|c|}{ Rogers Site, sampling date: 1990 (two years after application) } \\
\hline & $\begin{array}{l}\mathrm{U}(\mathrm{mg} / \mathrm{kg}) \\
{ }^{137} \mathrm{Cs}(\mathrm{pCi} / \mathrm{kg}) \\
{ }^{60} \mathrm{Co}(\mathrm{pCi} / \mathrm{kg}) \\
{ }^{40} \mathrm{~K}(\mathrm{pCi} / \mathrm{kg}) \\
{ }^{7} \mathrm{Be}(\mathrm{pCi} / \mathrm{kg})\end{array}$ & $\begin{array}{c}{[<0.01-0.03]} \\
{[<14-34]} \\
<16 \\
26100 \pm 5200 \\
1490 \pm 662\end{array}$ & $\begin{array}{c}<0.01 \\
{[<16-26]} \\
<24 \\
22300 \pm 1660 \\
3440 \pm 383\end{array}$ \\
\hline & \multicolumn{3}{|c|}{$\begin{array}{l}\text { Hayfield } 1 \text { and } 2 \text { sites, sampling date: } 1990 \text { (one to three months after } \\
\text { application) }\end{array}$} \\
\hline & $\begin{array}{l}{ }^{137} \mathrm{Cs}(\mathrm{pCi} / \mathrm{kg}) \\
{ }^{60} \mathrm{Co}(\mathrm{pCi} / \mathrm{kg}) \\
{ }^{40} \mathrm{~K}(\mathrm{pCi} / \mathrm{kg}) \\
{ }^{7} \mathrm{Be}(\mathrm{pCi} / \mathrm{kg})\end{array}$ & $\begin{array}{c}44 \pm 9 \\
<14.2 \\
22018 \pm 4242 \\
2337 \pm 523\end{array}$ & $\begin{array}{c}14.2 \pm 1.6 \\
<14.3 \\
19440 \pm 4766 \\
1334 \pm 556\end{array}$ \\
\hline \multirow[t]{2}{*}{$\begin{array}{l}\text { Pine needles } \\
\text { (new growth) }\end{array}$} & \multicolumn{3}{|c|}{ Pine Plantation Site, sampling date: 1990 (one year after application) } \\
\hline & $\begin{array}{l}\mathrm{U}(\mathrm{mg} / \mathrm{kg}) \\
{ }^{137} \mathrm{Cs}(\mathrm{pCi} / \mathrm{kg}) \\
{ }^{60} \mathrm{Co}(\mathrm{pCi} / \mathrm{kg}) \\
{ }^{40} \mathrm{~K}(\mathrm{pCi} / \mathrm{kg}) \\
{ }^{7} \mathrm{Be}(\mathrm{pCi} / \mathrm{kg})\end{array}$ & $\begin{array}{c}0.11 \pm 0.08 \\
{[<15-34]} \\
{[<12-29]} \\
3618 \pm 287 \\
1913 \pm 67\end{array}$ & $\begin{array}{c}0.03 \pm 0.01 \\
<15 \\
<15 \\
3811 \pm 602 \\
2381 \pm 359\end{array}$ \\
\hline
\end{tabular}

Values are means \pm std deviations or ranges [in brackets] for $n=3-6$ treatment samples and $n=2-3$ reference samples. Data for the Rogers pasture and Pine Plantation sites taken from Boston, et al., 1990. 


\section{SOIL WATER}

\subsection{METHODS OF SAMPLING AND ANALYSIS}

Ceramic cup tube lysimeters placed at various depths were used to monitor soil water at several of the sludge application sites, including the Rogers Site, the Pine Plantation Site, and the Cottonwood Site. Three types of lysimeters were used: shallow lysimeters (designated as "A" lysimeters), sampling sod water at $10-15 \mathrm{~cm}$, 3-ft lysimeters that sampled soil water from 40-60 cm ("B" type), and deep lysimeters (6-ft, or type " $\mathrm{C}$ "), sampling soil water from $120-150 \mathrm{~cm}$ from the surface. Not all types of lysimeters were used at all sites, and even on the Pine Plantation Site, where all three types were in place, not all types were sampled throughout the project. The " $\mathrm{B}$ " lysimeters were sampled throughout and at all three sites, and these are the data upon which this report is focused. Soil water $\mathrm{pH}$, conductivity, alkalinity, nitrate nitrogen, ammonium nitrogen, TKN, and total $P$ in the water from these lysimeters were measured in the ORNL ESD laboratory, and samples were also analyzed by ICP (University of Georgia or Analytical Chemistry Division, ORNL) and radionuclides by gamma ray spectrometry or ICP/mass spectrometry and neutron activation at ORNL and ORAU, respectively.

The Pine Plantation Site had lysimeters at all three depths and at three slope positions in each plot. The experimental design involved four separate treatments with three plots (replicates) in each. One set of plots had sludge application only ("S"), one had sludge application plus sawdust ("D," which would theoretically retain the nitrogen longer), and one had sludge plus an herbicide treatment of the understory vegetation ("H," which would theoretically decrease competition for nutrients between the pines and understory weeds and possibly release more nutrients to the soil water). One set remained as a reference ("R"), with no sludge applied. The " $\mathrm{B}$ " lysimeters were monitored during the sludge application period (June 1988 and June 1989) and through April of 1990, ten months after application ended. Metals were monitored only through February 1990. Data presented are the mean concentrations in each set of plots, along with the range of all values that were above the detection limits.

The "C" lysimeters (6-ft, sampling soil water from $120-150 \mathrm{~cm}$ below the surface) at the Pine Site were monitored only from October 1989 through April 1990, after the application had ended. Water volume in these deep lysimeters was sometimes inadequate for all analyses to be performed.

At the Rogers Site, almost all of the samples analyzed were from 3-ft lysimeters, which were placed in both sludge-treated and untreated reference areas. Samples were analyzed for water chemistry, nutrients, selected metals, and additional metals by ICP. Not all samples yielded sufficient volume for all analyses. Cottonwood site lysimeters were also of the 3-ft type.

\subsection{RESULTS}

Table 6.1 shows the metals concentrations [Table 6.1(a)] and additional soil chemistry data [Table 6.1(b)] for the " $\mathrm{B}$ " lysimeters for each of the four treatment plots in the Pine 
Plantation. Lysimeters from all three sludge application plots showed elévated concentrations of $\mathrm{Ca}, \mathrm{Y}, \mathrm{Mg}, \mathrm{Mn}, \mathrm{Na}$, and $\mathrm{Zn}$ [Table 6.1(a)]. Mean concentrations in the sludge lysimeters ranged from approximately 5 times $(\mathrm{Na}$ and $\mathrm{Zn}$ ), to 10 to 20 times $(\mathrm{Mg}, \mathrm{Ca}$, and $\mathrm{K})$, and 50 to 100 times $(\mathrm{Mn})$ the concentrations in the reference lysimeters. Concentrations of other elements were similar in sludge-treated and reference areas, or were not clearly higher. For example, for $\mathrm{Al}$, the mean for $\mathrm{S}$ plots (but not $\mathrm{D}$ or $\mathrm{H}$ ) was higher, but the range of values overlapped significantly; and for $\mathrm{Cd}$, no samples from the reference lysimeters had values above the detection limits, but few sludge-treated samples were above these limits either, and all concentrations were very low. Mercury was not detected in any of the samples. "B" lysimeters from sludge-treated sites also had higher conductivity (Table 6.lb), higher nitrate and ammonium nitrogen, and higher total nitrogen and total phosphorus. Mean nitrate concentrations in the sludge lysimeters ranged up to $68 \mathrm{mg} / \mathrm{L}$, compared to $0.15 \mathrm{mg} / \mathrm{L}$ in the reference lysimeters.

Table 6.2 shows the data from the " $\mathrm{C}$ " lysimeters at the Pine Plantation. Although the means for some metals (Table 6.2a) appeared higher in the S, or sludge-only treated plots, in most cases, the range of values for " $S$ " and " $R$ " plots overlapped substantially. This is not true for $\mathrm{Ni}$ or $\mathrm{Zn}$, but since neither $\mathrm{Ni}$ nor $\mathrm{Zn}$ was elevated in the "B" lysimeters, it is more likely that this resulted from the very small sample sizes. None of the metals or other ICP analytes in the " $\mathrm{C}$ " lysimeters showed a pattern of higher concentrations in all sludge plots, as some did in the more shallow " $\mathrm{B}^{n}$ lysimeters. Other measures of water chemistry (Table $6.2 \mathrm{~b}$ ) suggested a higher conductivity and total $\mathrm{N}$, although sample sizes were still small ( $n=6$ to 12 for "S" and "R" plots, with almost no data for "D" and "H" plots). Means for nitrate and ammonium nitrogen were also higher in the sludge plots, but ranges overlapped those of the reference plots.

Table 6.3 presents the data from the Rogers site, with data on water chemistry, nutrients, and selected metals (see table for methods) from March 1987 through April 1988. Nitrate and total phosphorus data are also presented from the longer sampling period of March 1987 through March 1990). Metals analyzed by ICP are presented for samples taken from March 1987 through February 1990. Nitrate $N$ concentrations were similar to those from the Pine lysimeters (means of 66 and $1.7 \mathrm{mg} / \mathrm{L}$ in sludge and reference soil water, respectively), and nutrient levels in general were higher in samples from sludge plots, e.g., $\mathrm{NH}_{4}-\mathrm{N}$, total $\mathrm{P}$, total $\mathrm{N}, \mathrm{K}, \mathrm{Ca}$, and $\mathrm{Mg}$. Concentrations of most other metals were not substantially elevated, although no statistical analysis was performed. Notably, levels of $\mathrm{Cd}, \mathrm{Cu}, \mathrm{Hg}, \mathrm{Pb}$, and $\mathrm{Ni}$ were not elevated.

Table 6.4 presents the data on water chemistry, nutrients, and metals in soil water from the Cottonwood site. Sampling was carried out between November 1989 and February 1990. Nitrogen (all forms) was again elevated in the sludge plot lysimeters, as were $\mathbf{K}$ and $\mathbf{P}$ (by ICP). Ca concentrations were 85 and 24 in the sludge and reference samples, respectively, and $\mathrm{Mg}, \mathrm{Mn}$, and $\mathrm{Na}$ were also elevated. As at the other sites, soil water concentrations of heavy metals were not particularly high.

There was also a limited amount of lysimeter data available from the McCoy and Sycamore sites, limited to data on metals (Table 6.5), showing similar results. Radionuclides in soil water were also measured once in the "sludge-only" and reference lysimeters in the Pine Plantation (Table 6.6), and there was little evidence of ${ }^{137} \mathrm{Cs}$ or ${ }^{60} \mathrm{Co}$ entering the soil water. 
Table 6.1. Soil water chemistry (inctuding metals) from lysimeters at the Pine Plantation site

(a) Metals data ${ }^{b}$

\begin{tabular}{|c|c|c|c|c|c|}
\hline & Detection limit (ppm) & Treatment & No. of detects/ total & Mean & Range \\
\hline Al & 0.05 & $\begin{array}{l}\mathbf{S} \\
\mathrm{D} \\
\mathrm{H} \\
\mathrm{R}\end{array}$ & $\begin{array}{l}49 / 89 \\
25 / 31 \\
26 / 30 \\
32 / 63\end{array}$ & $\begin{array}{l}0.604 \\
0.230 \\
0.219 \\
0.238\end{array}$ & $\begin{array}{c}0.051-3.41 \\
0.054-0.634 \\
0.057-1.044 \\
0.054-2.002\end{array}$ \\
\hline B & 0.02 & $\begin{array}{l}\text { S } \\
\text { D } \\
H \\
\text { R }\end{array}$ & $\begin{array}{l}86 / 89 \\
29 / 31 \\
29 / 30 \\
41 / 63\end{array}$ & $\begin{array}{l}0.049 \\
0.049 \\
0.044 \\
0.034\end{array}$ & $\begin{array}{l}0.021-0.114 \\
0.023-0.095 \\
0.024-0.080 \\
0.020-0.073\end{array}$ \\
\hline $\mathrm{Ca}$ & 1.0 & $\begin{array}{l}S \\
D \\
H \\
R\end{array}$ & $\begin{array}{l}89 / 89 \\
31 / 31 \\
30 / 30 \\
63 / 63\end{array}$ & $\begin{array}{r}90.41 \\
88.09 \\
78.77 \\
4.88\end{array}$ & $\begin{array}{l}17.2-301.2 \\
16.3-198.5 \\
25.2-220.0 \\
1.91-17.97\end{array}$ \\
\hline $\mathrm{Cd}$ & $0.001-0.01$ & $\begin{array}{l}S \\
D \\
H \\
R\end{array}$ & $\begin{array}{l}7 / 89 \\
3 / 31 \\
3 / 29 \\
0 / 63\end{array}$ & $\begin{array}{l}0.0058 \\
0.0024 \\
0.0016 \\
\text { ND }\end{array}$ & $\begin{array}{l}0.001-0.019 \\
0.001-0.003 \\
0.001-0.002\end{array}$ \\
\hline $\mathrm{Cr}$ & $0.001-0.005$ & $\begin{array}{l}\mathrm{S} \\
\mathrm{D} \\
\mathrm{H} \\
\mathrm{R}\end{array}$ & $\begin{array}{c}28 / 89 \\
11 / 32 \\
9 / 29 \\
18 / 63 \\
\end{array}$ & $\begin{array}{l}0.013 \\
0.017 \\
0.014 \\
0.023 \\
\end{array}$ & $\begin{array}{l}0.001-0.044 \\
0.003-0.035 \\
0.001-0.029 \\
0.002-0.056\end{array}$ \\
\hline $\mathrm{Cu}$ & $0.01-0.02$ & $\begin{array}{l}S \\
D \\
H \\
R\end{array}$ & $\begin{array}{c}14 / 89 \\
10 / 31 \\
6 / 30 \\
3 / 63\end{array}$ & $\begin{array}{l}0.030 \\
0.040 \\
0.018 \\
0.028\end{array}$ & $\begin{array}{l}0.011-0.055 \\
0.012-0.162 \\
0.011-0.027 \\
0.011-0.042\end{array}$ \\
\hline $\mathrm{Fe}$ & $0.003-0.004$ & $\begin{array}{l}S \\
D \\
H \\
R\end{array}$ & $\begin{array}{l}79 / 89 \\
28 / 30 \\
28 / 30 \\
36 / 63\end{array}$ & $\begin{array}{l}0.026 \\
0.026 \\
0.029 \\
0.032\end{array}$ & $\begin{array}{l}0.003-0.209 \\
0.006-0.124 \\
0.004-0.195 \\
0.003-0.365\end{array}$ \\
\hline $\mathbf{K}$ & 0.05 & $\begin{array}{l}\mathrm{S} \\
\mathrm{D} \\
\mathrm{H} \\
\mathrm{R}\end{array}$ & $\begin{array}{l}76 / 89 \\
30 / 31 \\
30 / 30 \\
26 / 63\end{array}$ & $\begin{array}{l}3.763 \\
6.356 \\
6.185 \\
0.250\end{array}$ & $\begin{array}{l}0.262-20.54 \\
0.351-17.81 \\
1.736-17.94 \\
0.060-0.589\end{array}$ \\
\hline $\mathrm{Mg}$ & 0.5 & $\begin{array}{l}S \\
D \\
H \\
R\end{array}$ & $\begin{array}{l}89 / 89 \\
31 / 31 \\
30 / 30 \\
63 / 63\end{array}$ & $\begin{array}{r}24.16 \\
22.19 \\
20.67 \\
1.92\end{array}$ & $\begin{array}{c}3.61-71.26 \\
6.22-60.65 \\
5.87-60.44 \\
0.95-4.38\end{array}$ \\
\hline $\mathbf{M n}_{\mathbf{n}}$ & 0.005 & $\begin{array}{l}S \\
D \\
H \\
\text { R }\end{array}$ & $\begin{array}{l}85 / 89 \\
31 / 31 \\
30 / 30 \\
45 / 63\end{array}$ & $\begin{array}{l}1.55 \\
2.23 \\
2.89 \\
0.029\end{array}$ & $\begin{array}{l}0.006-18.79 \\
0.139-14.21 \\
0.052-16.16 \\
0.006-0.242\end{array}$ \\
\hline Mo & 0.02 & $\begin{array}{l}\text { S } \\
\mathrm{D} \\
\mathrm{H} \\
\mathrm{R}\end{array}$ & $\begin{array}{c}19 / 87 \\
7 / 31 \\
9 / 29 \\
3 / 63\end{array}$ & $\begin{array}{l}0.045 \\
0.038 \\
0.035 \\
0.023\end{array}$ & $\begin{array}{l}0.021-0.045 \\
0.022-0.100 \\
0.023-0.048 \\
0.020-0.029\end{array}$ \\
\hline $\mathrm{Na}$ & 0.5 & $\begin{array}{l}S \\
\mathrm{D} \\
\mathrm{H} \\
\mathrm{R} \\
\end{array}$ & $\begin{array}{l}89 / 89 \\
31 / 31 \\
30 / 30 \\
60 / 63\end{array}$ & $\begin{array}{l}6.33 \\
5.24 \\
5.05 \\
0.877\end{array}$ & $\begin{array}{c}0.754-26.26 \\
1.74-13.79 \\
1.02-17.05 \\
0.503-1.68\end{array}$ \\
\hline $\mathrm{Ni}$ & 0.005 & $\begin{array}{l}S \\
D \\
H \\
R\end{array}$ & $\begin{array}{l}43 / 88 \\
17 / 31 \\
17 / 29 \\
19 / 63\end{array}$ & $\begin{array}{l}0.014 \\
0.016 \\
0.015 \\
0.011\end{array}$ & $\begin{array}{l}0.005-0.042 \\
0.007-0.037 \\
0.006-0.032 \\
0.005-0.023\end{array}$ \\
\hline
\end{tabular}


41

Table 6.1 (continued)

\begin{tabular}{|c|c|c|c|c|c|}
\hline & Detection limit (ppm) & Treatment & No. of detects/ total & Mean & Range \\
\hline $\mathrm{Pb}$ & $0.01-0.02$ & $\begin{array}{l}S \\
D \\
H \\
R\end{array}$ & $\begin{array}{l}0 / 89 \\
0 / 31 \\
2 / 30 \\
1 / 63\end{array}$ & $\begin{array}{l}\text { ND } \\
\text { ND } \\
0.016 \\
0.021\end{array}$ & $\begin{array}{c}0.011-0.020 \\
0.021\end{array}$ \\
\hline $\mathrm{Zn}$ & 0.01 & $\begin{array}{l}\mathbf{S} \\
\mathbf{D} \\
\mathrm{H} \\
\mathbf{R}\end{array}$ & $\begin{array}{l}89 / 89 \\
31 / 31 \\
30 / 30 \\
63 / 63\end{array}$ & $\begin{array}{l}0.218 \\
0.185 \\
0.230 \\
0.044\end{array}$ & $\begin{array}{l}0.026-1.854 \\
0.030-0.81 .7 \\
0.029-0.921 \\
0.013-0.209\end{array}$ \\
\hline $\mathrm{Hg}$ & 0.0008 & $\stackrel{S}{R}$ & $\begin{array}{r}0 / 33 \\
. \quad 0 / 33\end{array}$ & $\begin{array}{l}\text { ND } \\
\text { ND }\end{array}$ & \\
\hline
\end{tabular}

(b). Additional water chemistry for Pine Plantation "B" lysimeters

\begin{tabular}{|c|c|c|c|c|}
\hline & Treatment & Sample size (n) & Mean & Range \\
\hline Conductivity & $\begin{array}{l}\text { S } \\
\mathrm{D} \\
\mathrm{H} \\
\mathrm{R}\end{array}$ & $\begin{array}{r}109 \\
39 \\
36 \\
78\end{array}$ & $\begin{array}{r}639 \\
588 \\
631 \\
49\end{array}$ & $\begin{array}{c}103-2300 \\
80-1787 \\
120-1953 \\
24-150\end{array}$ \\
\hline $\mathrm{pH}$ & $\begin{array}{l}\mathrm{S} \\
\mathrm{D} \\
\mathrm{H} \\
\mathrm{R}\end{array}$ & $\begin{array}{r}105 \\
39 \\
36 \\
75\end{array}$ & $\begin{array}{l}5.85 \\
5.97 \\
5.58 \\
5.96\end{array}$ & $\begin{array}{l}3.94-7.53 \\
4.68-7.39 \\
4.39-6.83 \\
4.94-7.42\end{array}$ \\
\hline Alkalinity & $\begin{array}{l}\text { S } \\
\text { D } \\
\text { H } \\
\text { R }\end{array}$ & $\begin{array}{l}63 \\
25 \\
18 \\
41\end{array}$ & $\begin{array}{c}9.30 \\
16.9 \\
4.33 \\
9.85\end{array}$ & $\begin{array}{c}0.3-38.5 \\
0.2-68 \\
0.1-27 \\
0.22-90\end{array}$ \\
\hline $\mathrm{NO}_{3}-\mathrm{N}$ & $\begin{array}{l}\text { S } \\
\mathrm{D} \\
\mathrm{H} \\
\mathrm{R}\end{array}$ & $\begin{array}{r}110 \\
33 \\
37 \\
78\end{array}$ & $\begin{array}{c}68.32 \\
58.06 \\
64.82 \\
0.146\end{array}$ & $\begin{array}{c}0.436-277 \\
0.489-201 \\
4.09-233 \\
0-3.81\end{array}$ \\
\hline $\mathrm{NH}_{4}-\mathrm{N}$ & $\begin{array}{l}S \\
D \\
H \\
R\end{array}$ & $\begin{array}{r}109 \\
33 \\
37 \\
79\end{array}$ & $\begin{array}{c}703.49 \\
1050 \\
1214 \\
19.87\end{array}$ & $\begin{array}{c}0-15060 \\
4.92-10898 \\
4.76-11976 \\
0-545.6\end{array}$ \\
\hline Total N & $\begin{array}{l}\mathrm{S} \\
\mathrm{D} \\
\mathrm{H} \\
\mathrm{R}\end{array}$ & $\begin{array}{r}106 \\
33 \\
33 \\
64\end{array}$ & $\begin{array}{c}70.94 \\
61.71 \\
69.53 \\
0.544\end{array}$ & $\begin{array}{c}0.206-278.0 \\
0.959-207.7 \\
0.57-231.86 \\
0.053-3.85\end{array}$ \\
\hline Total $\mathbf{P}$ & $\begin{array}{l}\text { S } \\
\mathrm{D} \\
\mathrm{H} \\
\mathrm{R}\end{array}$ & $\begin{array}{r}106 \\
33 \\
32 \\
64\end{array}$ & $\begin{array}{l}0.757 \\
0.720 \\
0.87 \\
0.0132\end{array}$ & $\begin{array}{c}0.009-8.90 \\
0.012-2.655 \\
0.01-4.26 \\
0-0.122\end{array}$ \\
\hline
\end{tabular}

"These 3-ft, or "B" depth lysimeters sampled soil water from $40-60 \mathrm{~cm}$ deep in the soil profile. The four treatment codes designate the following: " $\mathrm{S}=$ sludge application only, $" \mathrm{D} "=$ sludge application plus sawdust, " $\mathrm{H}$ " = sludge appplication plus herbicide to the understory, and " $\mathrm{R}^{\mathrm{H}}=$ reference (no sludge applied).

${ }^{b}$ The mean listed is the mean of those values which were above the detection limits for the analysis method used for each measurement. ND indicates that no samples had detectable levels of the metal. Mercury data is for both " $A$ " (10-15 cm) and "B" lysimeters. Units are $\mathrm{mg} / \mathrm{L}$ for all metais. $\mathrm{P}, \mathbf{m g} / \mathrm{L}$.

'Units for conductivity are $\mu$ mhos/cm; for alkalinity, $\mathrm{mg} / \mathrm{L}$; for $\mathrm{NO}_{3}-\mathrm{N}, \mathrm{mg} \mathrm{N} / \mathrm{L}$; for $\mathrm{NH}_{4}-\mathrm{N}, \mu \mathrm{g} \mathrm{N} / \mathrm{L}$; and for total $\mathrm{N}$ and 
Table 6.2. Soil water chemistry (including metals) from deep lysimeters at the Pine Plantation site ${ }^{a}$

(a). Metals data ${ }^{b}$

\begin{tabular}{|c|c|c|c|c|c|}
\hline & Detection limit (ppm) & Treatment & No. of detects/ total & Mean & Range \\
\hline $\mathrm{Al}$ & 0.05 & $\begin{array}{l}\mathrm{S} \\
\mathrm{D} \\
\mathrm{H} \\
\mathrm{R}\end{array}$ & $\begin{array}{l}3 / 4 \\
0 / 1 \\
1 / 2 \\
3 / 5\end{array}$ & $\begin{array}{l}0.770 \\
\mathrm{ND} \\
0.060 \\
1.242\end{array}$ & $\begin{array}{l}0.095-1.740 \\
0.132-3.305\end{array}$ \\
\hline B & 0.02 & $\begin{array}{l}\text { S } \\
\text { D } \\
\text { H } \\
\text { R }\end{array}$ & $\begin{array}{l}4 / 4 \\
0 / 1 \\
1 / 2 \\
4 / 5\end{array}$ & $\begin{array}{c}0.033 \\
\mathrm{ND} \\
0.028 \\
0.031\end{array}$ & $\begin{array}{c}0.028-0.041 \\
0.028 \\
0.023-0.048\end{array}$ \\
\hline $\mathrm{Ca}$ & 1.0 & $\begin{array}{l}\mathrm{S} \\
\mathrm{D} \\
\mathrm{H} \\
\mathrm{R}\end{array}$ & $\begin{array}{l}4 / 4 \\
1 / 1 \\
2 / 2 \\
5 / 5\end{array}$ & $\begin{array}{r}26.85 \\
3.89 \\
11.16 \\
13.52 \\
\end{array}$ & $\begin{array}{c}3.11-42.37 \\
3.89 \\
4.44-17.87 \\
2.29-56.71\end{array}$ \\
\hline $\mathrm{Cd}$ & $0.001-0.01$ & $\begin{array}{l}\mathrm{S} \\
\mathrm{D} \\
\mathrm{H} \\
\mathrm{R}\end{array}$ & $\begin{array}{l}0 / 4 \\
0 / 1 \\
0 / 2 \\
0 / 5 \\
\end{array}$ & $\begin{array}{l}\text { ND } \\
\text { ND } \\
\text { ND } \\
\text { ND } \\
\end{array}$ & \\
\hline $\mathrm{Cr}$ & $0.001-0.005$ & $\begin{array}{l}\mathrm{S} \\
\mathrm{D} \\
\mathrm{H} \\
\mathrm{R}\end{array}$ & $\begin{array}{l}1 / 4 \\
0 / 1 \\
0 / 2 \\
3 / 5\end{array}$ & $\begin{array}{l}0.0235 \\
\text { ND } \\
\text { ND } \\
0.0103\end{array}$ & $\begin{array}{c}0.0235 \\
0.007-0.015\end{array}$ \\
\hline $\mathrm{Cu}$ & $0.01-0.02$ & $\begin{array}{l}S \\
D \\
H \\
R\end{array}$ & $\begin{array}{l}1 / 4 \\
0 / 1 \\
0 / 2 \\
0 / 5\end{array}$ & $\begin{array}{l}0.0234 \\
\text { ND } \\
\text { ND } \\
\text { ND }\end{array}$ & 0.0234 \\
\hline $\mathrm{Fe}$ & $0.003-0.004$ & $\begin{array}{l}\mathrm{S} \\
\mathrm{D} \\
\mathrm{H} \\
\mathrm{R}\end{array}$ & $\begin{array}{l}5 / 5 \\
0 / 1 \\
2 / 2 \\
3 / 5\end{array}$ & $\begin{array}{l}0.0058 \\
\mathrm{ND} \\
0.016 \\
0.0069\end{array}$ & $\begin{array}{c}0.003-0.0083 \\
0.011-0.022 \\
0.003-0.014\end{array}$ \\
\hline $\mathrm{K}$ & 0.05 & $\begin{array}{l}\mathrm{S} \\
\mathrm{D} \\
\mathrm{H} \\
\mathrm{R}\end{array}$ & $\begin{array}{l}5 / 5 \\
1 / 1 \\
2 / 2 \\
5 / 5\end{array}$ & $\begin{array}{l}1.366 \\
0.495 \\
0.497 \\
0.825\end{array}$ & $\begin{array}{c}0.114-2.172 \\
0.495 \\
0.254-0.740 \\
0.363-2.492\end{array}$ \\
\hline $\mathrm{Mg}$ & 0.5 & $\begin{array}{l}\mathrm{S} \\
\mathrm{D} \\
\mathrm{H} \\
\mathrm{R}\end{array}$ & $\begin{array}{l}5 / 5 \\
1 / 1 \\
2 / 2 \\
5 / 5\end{array}$ & $\begin{array}{l}9.213 \\
0.897 \\
3.608 \\
5.55 \\
\end{array}$ & $\begin{array}{c}0.677-15.32 \\
0.897 \\
0.889-6.327 \\
0.977-22.53\end{array}$ \\
\hline $\mathrm{Mn}$ & 0.005 & $\begin{array}{l}S \\
D \\
H \\
R\end{array}$ & $\begin{array}{l}5 / 5 \\
1 / 1 \\
2 / 2 \\
5 / 5\end{array}$ & $\begin{array}{l}0.443 \\
0.016 \\
0.0289 \\
0.1996 \\
\end{array}$ & $\begin{array}{c}0.083-0.840 \\
0.016 \\
0.0103-0.047 \\
0.015-0.910\end{array}$ \\
\hline Mo & 0.02 & $\begin{array}{l}S \\
D \\
H \\
R\end{array}$ & $\begin{array}{l}1 / 5 \\
0 / 1 \\
0 / 2 \\
0 / 4\end{array}$ & $\begin{array}{l}0.020 \\
\text { ND } \\
\text { ND } \\
\text { ND }\end{array}$ & 0.020 \\
\hline
\end{tabular}


43

Table 6.2 (continued)

\begin{tabular}{|l|c|c|c|c|c|}
\hline & Detection limit (ppm) & Treatment & No. of detects/ total & Mean & Range \\
\hline $\mathrm{Na}$ & 0.5 & $\mathrm{~S}$ & $5 / 5$ & 2.87 & $0.97-3.79$ \\
& & $\mathrm{D}$ & $1 / 1$ & 0.878 & 0.878 \\
& & $\mathrm{H}$ & $2 / 2$ & 1.075 & $0.953-1.196$ \\
& & $\mathrm{R}$ & $5 / 5$ & 1.987 & $1.005-4.667$ \\
\hline $\mathrm{Ni}$ & 0.005 & $\mathrm{~S}$ & $4 / 5$ & 0.224 & $0.104-0.383$ \\
& & $\mathrm{D}$ & $1 / 1$ & 0.0083 & 0.0083 \\
& & $\mathrm{H}$ & $1 / 2$ & 0.0081 & 0.0081 \\
& & $\mathrm{R}$ & $5 / 5$ & 0.0806 & $0.052-0.128$ \\
\hline $\mathrm{Pb}$ & \multirow{2}{*}{$0.01-0.02$} & $\mathrm{~S}$ & $0 / 5$ & $\mathrm{ND}$ & \\
& & $\mathrm{D}$ & $0 / 1$ & $\mathrm{ND}$ & \\
& & $\mathrm{H}$ & $0 / 2$ & $\mathrm{ND}$ & \\
& & $\mathrm{R}$ & $0 / 5$ & $\mathrm{ND}$ & \\
\hline $\mathrm{Zn}$ & & $\mathrm{S}$ & $5 / 5$ & 0.125 & $0.043-0.241$ \\
& \multirow{2}{*}{0.01} & $\mathrm{D}$ & $1 / 1$ & 0.031 & 0.031 \\
& & $\mathrm{H}$ & $2 / 2$ & 0.034 & $0.022-0.047$ \\
& & $\mathrm{R}$ & $5 / 5$ & 0.057 & $0.029-0.118$ \\
\hline
\end{tabular}

(b). Additional water chemistry for Pine Plantation " $\mathrm{C}$ " lysimeters

\begin{tabular}{|c|c|c|c|c|}
\hline & Treatment & Sample size (n) & Mean & Range \\
\hline Conductivity & $\begin{array}{l}S \\
R\end{array}$ & $\begin{array}{c}12 \\
9\end{array}$ & $\begin{array}{r}354.5 \\
41.9\end{array}$ & $\begin{array}{c}111-562 \\
25-70\end{array}$ \\
\hline $\mathrm{pH}$ & $\begin{array}{l}\mathbf{S} \\
\mathrm{R}\end{array}$ & $\begin{array}{c}10 \\
9\end{array}$ & $\begin{array}{l}5.56 \\
5.67\end{array}$ & $\begin{array}{l}4.45-7.24 \\
4.96-6.16\end{array}$ \\
\hline Alkalinity & $\begin{array}{l}\mathrm{S} \\
\mathrm{R}\end{array}$ & $\begin{array}{l}8 \\
8\end{array}$ & $\begin{array}{r}10.42 \\
9.84\end{array}$ & $\begin{array}{c}0.40-64.4 \\
0.046-65.84\end{array}$ \\
\hline $\mathrm{NO}_{3}-\mathrm{N}$ & $\begin{array}{l}\mathrm{S} \\
\mathrm{D} \\
\mathrm{R}\end{array}$ & $\begin{array}{c}10 \\
1 \\
7\end{array}$ & $\begin{array}{r}48.48 \\
11.01 \\
9.84\end{array}$ & $\begin{array}{c}11.55-145.39 \\
11.01 \\
0.046-65.85\end{array}$ \\
\hline $\mathrm{NH}_{3}-\mathrm{N}$ & $\begin{array}{l}\mathrm{S} \\
\mathrm{D} \\
\mathrm{R}\end{array}$ & $\begin{array}{c}10 \\
1 \\
7\end{array}$ & $\begin{array}{r}105.78 \\
6.64 \\
40.33\end{array}$ & $\begin{array}{c}32.45-173.32 \\
6.64 \\
5.00-71.63\end{array}$ \\
\hline Total N & $\begin{array}{l}\mathrm{S} \\
\mathrm{R}\end{array}$ & $\begin{array}{l}8 \\
6 \\
\end{array}$ & $\begin{array}{r}39.30 \\
0.66\end{array}$ & $\begin{array}{c}11.31-90.21 \\
0.15-1.19\end{array}$ \\
\hline Total $\mathrm{P}$ & $\begin{array}{l}\mathbf{S} \\
\mathbf{R}\end{array}$ & $\begin{array}{l}8 \\
6\end{array}$ & $\begin{array}{l}0.021 \\
0.013\end{array}$ & $\begin{array}{c}0.01-0.04 \\
0.006-0.021\end{array}$ \\
\hline
\end{tabular}

${ }^{a}$ These 6-foot, or " $\mathrm{C}$ " depth lysimeters sampled soil water from 120-150 cm depth in the soil profile. The four treatment codes designate the following: " $\mathrm{S}$ " = sludge application only, " $\mathrm{D}$ = sludge application plus sawdust, " $H "$ = sludge appplication plus herbicide to the understory, and " $\mathrm{R}^{\mathrm{N}}=$ reference (no sludge applied).

${ }^{b}$ The mean listed is the mean of those values which were above the detection limits for the analysis method used for each measurement. ND indicates that no samples had detectable levels of the metal. No samples were large enough for mercury analyses. Units are $\mathrm{mg} / \mathrm{L}$ for all metals.

${ }^{\circ}$ Data were not usually available from $\mathrm{D}$ or $\mathrm{H}$ lysimeters (see text). Units for conductivity are $\mu \mathrm{mhos} / \mathrm{cm}$; for alkalinity, mg/L; for $\mathrm{NO}_{3}-\mathrm{N}, \mathrm{mg} \mathrm{N} / \mathrm{L}$; for $\mathrm{NH}_{4}-\mathrm{N} \mu \mathrm{g} \mathrm{N} / \mathrm{L}$; and for Total $\mathrm{N}$ and $\mathrm{P}, \mathrm{mg} / \mathrm{L}$. 
Table 6.3. Soil water chemistry and metals at the Rogers site, measured in 40 - to $60 \mathrm{~cm}$ deep lysimeters.

\begin{tabular}{|c|c|c|c|c|c|c|}
\hline & \multirow[t]{2}{*}{ Treatment } & \multirow[t]{2}{*}{$\begin{array}{c}\text { Number of } \\
\text { samples } \\
\text { analyzed }\end{array}$} & \multicolumn{3}{|c|}{ Values above detection limits } & \multirow[t]{2}{*}{$\begin{array}{c}\text { Range of } \\
\text { detection } \\
\text { limits }\end{array}$} \\
\hline & & & Number & Mean & Range & \\
\hline \multicolumn{7}{|c|}{ pH through $\mathrm{Pb}$ (graphite furnace), 3/87-4/88 } \\
\hline $\mathrm{pH}$ & $\begin{array}{l}\text { Sludge } \\
\text { Reference }\end{array}$ & $\begin{array}{l}52 \\
42\end{array}$ & $\begin{array}{l}\text { NA } \\
\text { NA }\end{array}$ & $\begin{array}{l}6.81 \\
6.73\end{array}$ & $\begin{array}{l}5.26-8.33 \\
5.48-8.06\end{array}$ & . \\
\hline $\begin{array}{l}\text { Alkal. } \\
(\mathrm{mg} / \mathrm{L})\end{array}$ & $\begin{array}{l}\text { Sludge } \\
\text { Reference }\end{array}$ & $\begin{array}{l}38 \\
33\end{array}$ & & $\begin{array}{l}88.4 \\
28.11\end{array}$ & $\begin{array}{l}3-448 \\
1.05-109\end{array}$ & \\
\hline $\begin{array}{l}\text { Conduct. } \\
(\mu \mathrm{mhos} / \mathrm{cm})\end{array}$ & $\begin{array}{l}\text { Sludge } \\
\text { Reference }\end{array}$ & $\begin{array}{l}58 \\
46\end{array}$ & & $\begin{array}{l}627 \\
108\end{array}$ & $\begin{array}{l}34-1668 \\
37-520\end{array}$ & \\
\hline $\begin{array}{l}\mathrm{NO}_{3}-\mathrm{N} \\
(\mathrm{mg} \mathrm{N} / \mathrm{L})\end{array}$ & $\begin{array}{l}\text { Sludge } \\
\text { Reference }\end{array}$ & $\begin{array}{l}65 \\
52\end{array}$ & & $\begin{array}{l}66 \\
1.69\end{array}$ & $\begin{array}{l}0-472 \\
0-27.9\end{array}$ & \\
\hline $\begin{array}{l}\mathrm{NH}_{4}-\mathrm{N} \\
(\mu \mathrm{g} \mathrm{N} / \mathrm{L})\end{array}$ & $\begin{array}{l}\text { Sludge } \\
\text { Reference }\end{array}$ & $\begin{array}{l}36 \\
26\end{array}$ & & $\begin{array}{c}188 \\
66.2\end{array}$ & $\begin{array}{l}0-2027 \\
1.4-362.2\end{array}$ & \\
\hline $\begin{array}{l}\text { TKN } \\
(\mathrm{mg} \mathrm{N} / \mathrm{L}) \\
\end{array}$ & $\begin{array}{l}\text { Sludge } \\
\text { Reference } \\
\end{array}$ & $\begin{array}{l}15 \\
12 \\
\end{array}$ & & $\begin{array}{r}20.16 \\
0.52 \\
\end{array}$ & $\begin{array}{l}0.25-100 \\
0.14-1.38 \\
\end{array}$ & \\
\hline $\begin{array}{l}\text { Total P } \\
(\mathrm{mg} / \mathrm{L})\end{array}$ & $\begin{array}{l}\text { Sludge } \\
\text { Reference }\end{array}$ & $\begin{array}{l}21 \\
18 \\
\end{array}$ & $\begin{array}{l}20 \\
18 \\
\end{array}$ & $\begin{array}{l}0.290 \\
0.047 \\
\end{array}$ & $\begin{array}{l}0-1.45 \\
0.004-0.16 \\
\end{array}$ & 0.02 \\
\hline $\begin{array}{l}\mathrm{SO}_{4} \\
(\mathrm{mg} / \mathrm{L}) \\
\end{array}$ & $\begin{array}{l}\text { Sludge } \\
\text { Reference } \\
\end{array}$ & $\begin{array}{l}22 \\
14 \\
\end{array}$ & $\begin{array}{l}22 \\
14 \\
\end{array}$ & $\begin{array}{l}54.60 \\
19.52 \\
\end{array}$ & $\begin{array}{l}4.83-278 \\
6.08-33.6 \\
\end{array}$ & \\
\hline $\begin{array}{l}\mathrm{Cl} \\
(\mathrm{mg} / \mathrm{L})\end{array}$ & $\begin{array}{l}\text { Sludge } \\
\text { Reference }\end{array}$ & $\begin{array}{l}8 \\
4 \\
\end{array}$ & $\begin{array}{l}8 \\
4\end{array}$ & $\begin{array}{l}5.53 \\
3.48\end{array}$ & $\begin{array}{l}1.16-11.1 \\
1.56-8.18 \\
\end{array}$ & \\
\hline $\begin{array}{l}\mathrm{Cd}(\mu \mathrm{g} / \mathrm{L}) \\
\text { (graphite } \\
\text { furnace) }\end{array}$ & $\begin{array}{l}\text { Sludge } \\
\text { Reference }\end{array}$ & $\begin{array}{l}13 \\
11\end{array}$ & $\begin{array}{l}4 \\
3\end{array}$ & $\begin{array}{l}0.55 \\
0.96\end{array}$ & $\begin{array}{l}0.1-1.5 \\
0.1-2.6\end{array}$ & $\begin{array}{c}1 \\
0.1-1\end{array}$ \\
\hline $\begin{array}{l}\mathrm{Hg}(\mu \mathrm{g} / \mathrm{L}) \\
\text { (cold vapor) }\end{array}$ & $\begin{array}{l}\text { Sludge } \\
\text { Reference }\end{array}$ & $\begin{array}{l}13 \\
12 \\
\end{array}$ & $\begin{array}{l}1 \\
1\end{array}$ & $\begin{array}{l}0.1 \\
0.3\end{array}$ & & $\begin{array}{l}0.1-0.2 \\
0.1-0.2\end{array}$ \\
\hline $\begin{array}{l}\mathrm{Pb}(\mu \mathrm{g} / \mathrm{L}) \\
\text { (graphite } \\
\text { furnace) }\end{array}$ & $\begin{array}{l}\text { Sludge } \\
\text { Reference }\end{array}$ & $\begin{array}{l}14 \\
12\end{array}$ & $\begin{array}{l}13 \\
11\end{array}$ & $\begin{array}{l}2.34 \\
2.73\end{array}$ & $\begin{array}{l}0.6-5.0 \\
0.7-6\end{array}$ & $\begin{array}{l}1 \\
1\end{array}$ \\
\hline $\begin{array}{l}\mathrm{NO}_{3}(\mathrm{mg} / \mathrm{L}) \\
(3 / 87-/ 90)\end{array}$ & $\begin{array}{l}\text { Sludge } \\
\text { Reference }\end{array}$ & $\begin{array}{c}109 \\
83\end{array}$ & $\begin{array}{c}109 \\
83\end{array}$ & $\begin{array}{r}54.69 \\
1.28\end{array}$ & $\begin{array}{l}0.014-472 \\
0.001-27.9\end{array}$ & \\
\hline $\begin{array}{l}\text { Total P } \\
(\mathrm{mg} / \mathrm{L}) \\
(11 / 88-3 / 90)\end{array}$ & $\begin{array}{l}\text { Sludge } \\
\text { Reference }\end{array}$ & $\begin{array}{l}40 \\
45\end{array}$ & $\begin{array}{l}40 \\
45\end{array}$ & $\begin{array}{l}0.227 \\
0.858\end{array}$ & $\begin{array}{l}0-1.58 \\
0-10\end{array}$ & \\
\hline
\end{tabular}


45

Table 6.3 (continued)

\begin{tabular}{|c|c|c|c|c|c|c|}
\hline & \multirow[t]{2}{*}{ Treatment } & \multirow[t]{2}{*}{$\begin{array}{c}\text { Number of } \\
\text { samples } \\
\text { analyzed }\end{array}$} & \multicolumn{3}{|c|}{ Values above detection limits } & \multirow[t]{2}{*}{$\begin{array}{c}\text { Range of } \\
\text { detection } \\
\text { limits }\end{array}$} \\
\hline & & & Number & Mean & Range & \\
\hline \multicolumn{7}{|c|}{ ICP: 3/87-2,90 where available (mg/L) } \\
\hline $\mathrm{Ag}$ & $\begin{array}{l}\text { Sludge } \\
\text { Reference }\end{array}$ & $\begin{array}{l}7 \\
0\end{array}$ & 0 & & & $0.006-0.1$ \\
\hline Al & $\begin{array}{l}\text { Sludge } \\
\text { Reference }\end{array}$ & $\begin{array}{l}36 \\
19\end{array}$ & $\begin{array}{l}27 \\
14\end{array}$ & $\begin{array}{l}0.043 \\
0.015\end{array}$ & $\begin{array}{l}0-0.14 \\
0-0.047\end{array}$ & $\begin{array}{c}0-0.4 \\
0-0.06\end{array}$ \\
\hline As & $\begin{array}{l}\text { Sludge } \\
\text { Reference }\end{array}$ & $\begin{array}{l}7 \\
0\end{array}$ & 0 & & & $0.017-0.2$ \\
\hline B & $\begin{array}{l}\text { Shudge } \\
\text { Reference }\end{array}$ & $\begin{array}{l}34 \\
19\end{array}$ & $\begin{array}{l}28 \\
15\end{array}$ & $\begin{array}{l}0.036 \\
0.026\end{array}$ & $\begin{array}{l}0.006-0.208 \\
0.006-0.132\end{array}$ & $\begin{array}{c}0.035-0.16 \\
0\end{array}$ \\
\hline $\mathrm{Ba}$ & $\begin{array}{l}\text { Sludge } \\
\text { Reference }\end{array}$ & $\begin{array}{l}13 \\
10\end{array}$ & $\begin{array}{c}12 \\
9\end{array}$ & $\begin{array}{l}0.146 \\
0.070\end{array}$ & $\begin{array}{l}0.012-0.36 \\
0.006-0.43\end{array}$ & $\begin{array}{l}0.33 \\
0.02\end{array}$ \\
\hline $\mathrm{Be}$ & $\begin{array}{l}\text { Sludge } \\
\text { Reference }\end{array}$ & $\begin{array}{l}9 \\
0 \\
\end{array}$ & 1 & 0.00048 & & $0.0003-0.004$ \\
\hline $\mathrm{Ca}$ & $\begin{array}{l}\text { Sludge } \\
\text { Reference } \\
\end{array}$ & $\begin{array}{l}38 \\
29 \\
\end{array}$ & $\begin{array}{l}38 \\
29 \\
\end{array}$ & $\begin{array}{l}94.55 \\
17.16 \\
\end{array}$ & $\begin{array}{l}12-360 \\
2-49.45 \\
\end{array}$ & \\
\hline $\mathrm{Cd}$ & $\begin{array}{l}\text { Sludge } \\
\text { Reference }\end{array}$ & $\begin{array}{l}26 \\
16\end{array}$ & $\begin{array}{l}0 \\
0\end{array}$ & & & $\begin{array}{c}0-0.01 \\
0-?\end{array}$ \\
\hline Co & $\begin{array}{l}\text { Sjudge } \\
\text { Reference }\end{array}$ & $\begin{array}{l}9 \\
2\end{array}$ & $\begin{array}{l}2 \\
1\end{array}$ & $\begin{array}{l}0.0040 \\
0.0031\end{array}$ & $0.002-0.006$ & $\begin{array}{c}0.0017-0.4 \\
0.0017\end{array}$ \\
\hline $\mathrm{Cr}$ & $\begin{array}{l}\text { Sludge } \\
\text { Reference }\end{array}$ & $\begin{array}{l}32 \\
20\end{array}$ & $\begin{array}{c}14 \\
8\end{array}$ & $\begin{array}{l}0.0135 \\
0.0027\end{array}$ & $\begin{array}{l}0-0.0564 \\
0 \sim 0.009\end{array}$ & $\begin{array}{c}0-0.8 \\
0-0.006\end{array}$ \\
\hline $\mathrm{Cu}$ & $\begin{array}{l}\text { Sludge } \\
\text { Reference }\end{array}$ & $\begin{array}{l}38 \\
22 \\
\end{array}$ & $\begin{array}{c}21 \\
9\end{array}$ & $\begin{array}{l}0.0168 \\
0.0137\end{array}$ & $\begin{array}{l}0.0002-0.092 \\
0-0.048\end{array}$ & $\begin{array}{c}0.003-0.04 \\
0-0.02 \\
\end{array}$ \\
\hline $\mathrm{Hg}$ & $\begin{array}{l}\text { Sludge } \\
\text { Reference }\end{array}$ & $\begin{array}{l}4 \\
2\end{array}$ & $\begin{array}{l}4 \\
2\end{array}$ & $\begin{array}{l}0.0056 \\
0.0021\end{array}$ & $\begin{array}{l}0.0008-0.0199 \\
0.0013-0.003\end{array}$ & \\
\hline $\mathrm{Fe}$ & $\begin{array}{l}\text { Sludge } \\
\text { Reference }\end{array}$ & $\begin{array}{l}37 \\
21\end{array}$ & $\begin{array}{l}28 \\
14\end{array}$ & $\begin{array}{l}0.012 \\
0.004\end{array}$ & $\begin{array}{l}0.0008-0.033 \\
0-0.026\end{array}$ & $\begin{array}{c}0.005-0.06 \\
0-?\end{array}$ \\
\hline $\mathrm{Ga}$ & $\begin{array}{l}\text { Sludge } \\
\text { Reference }\end{array}$ & $\begin{array}{l}7 \\
0\end{array}$ & $\begin{array}{l}0 \\
0\end{array}$ & & & $0.05-0.6$ \\
\hline $\mathbf{K}$ & $\begin{array}{l}\text { Sludge } \\
\text { Reference }\end{array}$ & $\begin{array}{l}38 \\
27\end{array}$ & $\begin{array}{l}35 \\
22\end{array}$ & $\begin{array}{l}3.415 \\
0.663\end{array}$ & $\begin{array}{l}0-21 \\
0-4\end{array}$ & $\begin{array}{l}0-0.4 \\
0-0.4\end{array}$ \\
\hline $\mathrm{Li}$ & $\begin{array}{l}\text { Sludge } \\
\text { Reference }\end{array}$ & $\begin{array}{l}7 \\
0 \\
\end{array}$ & $\begin{array}{l}0 \\
0\end{array}$ & & & $0.088-0.4$ \\
\hline $\mathrm{Mg}$ & $\begin{array}{l}\text { Sludge } \\
\text { Reference }\end{array}$ & $\begin{array}{l}38 \\
29 \\
\end{array}$ & $\begin{array}{l}38 \\
29\end{array}$ & $\begin{array}{r}11.54 \\
1.78 \\
\end{array}$ & $\begin{array}{l}2.19-32 \\
0.079-3.9\end{array}$ & \\
\hline Mn & $\begin{array}{l}\text { Sludge } \\
\text { Reference }\end{array}$ & $\begin{array}{l}38 \\
28 \\
\end{array}$ & $\begin{array}{l}36 \\
25\end{array}$ & $\begin{array}{l}0.0503 \\
0.0316\end{array}$ & $\begin{array}{l}0.0008-0.269 \\
0-0.545\end{array}$ & $\begin{array}{c}0.005-0.03 \\
0.005\end{array}$ \\
\hline Mo & $\begin{array}{l}\text { Sludge } \\
\text { Reference }\end{array}$ & $\begin{array}{l}33 \\
19\end{array}$ & $\begin{array}{l}18 \\
11\end{array}$ & $\begin{array}{l}0.0099 \\
0.0005\end{array}$ & $\begin{array}{l}0-0.059 \\
0-0.002\end{array}$ & $\begin{array}{c}0.0067-0.08 \\
0-?\end{array}$ \\
\hline
\end{tabular}


46

Table 6.3 (continued)

\begin{tabular}{|c|c|c|c|c|c|c|}
\hline & \multirow[t]{2}{*}{ Treatment } & \multirow[t]{2}{*}{$\begin{array}{c}\text { Number of } \\
\text { samples } \\
\text { analyzed }\end{array}$} & \multicolumn{3}{|c|}{ Values above detection limits } & \multirow[t]{2}{*}{$\begin{array}{c}\begin{array}{c}\text { Range of } \\
\text { detection } \\
\text { limits }\end{array} \\
\end{array}$} \\
\hline & & & Number & Mean & Range & \\
\hline $\mathrm{Na}$ & $\begin{array}{l}\text { Sludge } \\
\text { Reference }\end{array}$ & $\begin{array}{l}38 \\
29\end{array}$ & $\begin{array}{l}37 \\
29\end{array}$ & $\begin{array}{l}4.755 \\
1.788\end{array}$ & $\begin{array}{l}0.944-17.18 \\
0.717-3.2\end{array}$ & 5 \\
\hline $\mathrm{Ni}$ & $\begin{array}{l}\text { Sludge } \\
\text { Reference }\end{array}$ & $\begin{array}{l}31 \\
21\end{array}$ & $\begin{array}{l}15 \\
12\end{array}$ & $\begin{array}{l}0.004 \\
0.002\end{array}$ & $\begin{array}{l}0-0.0112 \\
0-0.009\end{array}$ & $\begin{array}{c}0.006-0.12 \\
0-0.006\end{array}$ \\
\hline $\mathbf{P}$ & $\begin{array}{l}\text { Sludge } \\
\text { Reference }\end{array}$ & $\begin{array}{l}35 \\
21\end{array}$ & $\begin{array}{c}30 \\
9\end{array}$ & $\begin{array}{l}0.436 \\
0.29\end{array}$ & $\begin{array}{l}0.0096-2.35 \\
0.0026-2.35\end{array}$ & $\begin{array}{c}0.3-0.6 \\
0.05-0.3\end{array}$ \\
\hline $\mathrm{Pb}$ & $\begin{array}{l}\text { Sludge } \\
\text { Reference }\end{array}$ & $\begin{array}{l}32 \\
19\end{array}$ & $\begin{array}{c}11 \\
7\end{array}$ & $\begin{array}{l}0.0053 \\
0.0006\end{array}$ & $\begin{array}{l}0-0.0364 \\
0-0.0022\end{array}$ & $\begin{array}{l}0-0.4 \\
0-?\end{array}$ \\
\hline $\mathrm{Sb}$ & $\begin{array}{l}\text { Sludge } \\
\text { Reference }\end{array}$ & $\begin{array}{l}7 \\
0\end{array}$ & 0 & & & $0.03-0.4$ \\
\hline $\mathrm{Se}$ & $\begin{array}{l}\text { Sludge } \\
\text { Reference }\end{array}$ & $\begin{array}{l}7 \\
0\end{array}$ & 0 & & & $0.033-0.4$ \\
\hline $\mathrm{Si}$ & $\begin{array}{l}\text { Sludge } \\
\text { Reference }\end{array}$ & $\begin{array}{l}13 \\
12\end{array}$ & $\begin{array}{l}13 \\
12\end{array}$ & $\begin{array}{l}2.931 \\
3.008\end{array}$ & $\begin{array}{l}1.4-7.2 \\
1-5.4\end{array}$ & \\
\hline $\mathrm{Sn}$ & $\begin{array}{l}\text { Sludge } \\
\text { Reference }\end{array}$ & $\begin{array}{l}7 \\
0\end{array}$ & 0 & & & $0.0083-0.1$ \\
\hline $\mathrm{Sr}$ & $\begin{array}{l}\text { Sludge } \\
\text { Reference }\end{array}$ & $\begin{array}{l}13 \\
12\end{array}$ & $\begin{array}{l}13 \\
12\end{array}$ & $\begin{array}{l}0.19 \\
0.037\end{array}$ & $\begin{array}{l}0.066-0.44 \\
0.0044-0.21\end{array}$ & \\
\hline $\mathrm{Ti}$ & $\begin{array}{l}\text { Sludge } \\
\text { Reference }\end{array}$ & $\begin{array}{l}9 \\
1\end{array}$ & $\begin{array}{l}2 \\
0\end{array}$ & 0.00435 & $0.0042-0.0045$ & $\begin{array}{c}0.003-0.04 \\
0.0033\end{array}$ \\
\hline v & $\begin{array}{l}\text { Sludge } \\
\text { Reference }\end{array}$ & $\begin{array}{c}12 \\
5\end{array}$ & $\begin{array}{l}8 \\
3\end{array}$ & $\begin{array}{l}0.0405 \\
0.0353\end{array}$ & $\begin{array}{l}0.01-0.094 \\
0.024-0.058\end{array}$ & $\begin{array}{l}0.008-0.04 \\
0.004-0.02\end{array}$ \\
\hline $\mathrm{Zn}$ & $\begin{array}{l}\text { Sludge } \\
\text { Reference }\end{array}$ & $\begin{array}{l}38 \\
27\end{array}$ & $\begin{array}{l}37 \\
24\end{array}$ & $\begin{array}{l}0.062 \\
0.0439\end{array}$ & $\begin{array}{l}0.005-0.185 \\
0.0134-0.24\end{array}$ & $\begin{array}{c}0.003 \\
0.008-0.02\end{array}$ \\
\hline $\mathrm{Zr}$ & $\begin{array}{l}\text { Sludge } \\
\text { Reference }\end{array}$ & $\begin{array}{l}8 \\
0\end{array}$ & 3 & 0.023 & $0.0092-0.04$ & $0.003-0.04$ \\
\hline
\end{tabular}


Table 6.4. Soil water chemistry and metals in 3-ft lysimeters

(sampling 40-60 cm depth) at the Cottonwood Site

\begin{tabular}{|c|c|c|c|c|c|c|}
\hline & Treatment & $\begin{array}{l}\text { Number of } \\
\text { samples } \\
\text { analyzed }\end{array}$ & \multicolumn{3}{|c|}{ Values above detection limits } & \multirow[t]{2}{*}{$\begin{array}{l}\text { Range of } \\
\text { detection } \\
\text { limits }\end{array}$} \\
\hline & & & Number & Mean & Range & \\
\hline $\mathrm{pH}$ & $\begin{array}{l}\text { Sludge } \\
\text { Reference }\end{array}$ & $\begin{array}{l}13 \\
15\end{array}$ & $\begin{array}{l}13 \\
15\end{array}$ & $\begin{array}{l}5.80 \\
6.71\end{array}$ & $\begin{array}{l}4.82-6.58 \\
5.55-7.81 \\
\end{array}$ & \\
\hline $\begin{array}{l}\text { Alkal. } \\
(\mathrm{mg} / \mathrm{L})\end{array}$ & $\begin{array}{l}\text { Sludge } \\
\text { Reference }\end{array}$ & $\begin{array}{l}.11 \\
15\end{array}$ & $\begin{array}{l}11 \\
15\end{array}$ & $\begin{array}{l}15.15 \\
70.61\end{array}$ & $\begin{array}{l}3.0-62.1 \\
3.0-248\end{array}$ & \\
\hline $\begin{array}{l}\text { Conduct. } \\
(\mu \mathrm{mhos} / \mathrm{cm})\end{array}$ & $\begin{array}{l}\text { Sludge } \\
\text { Reference }\end{array}$ & $\begin{array}{l}14 \\
15\end{array}$ & $\begin{array}{l}14 \\
15\end{array}$ & $\begin{array}{l}389.1 \\
101.6\end{array}$ & $\begin{array}{l}37-883 \\
5.0-316\end{array}$ & \\
\hline $\begin{array}{l}\mathrm{NO}_{3}-\mathrm{N} \\
(\mathrm{mg} \mathrm{N} / \mathrm{L})\end{array}$ & $\begin{array}{l}\text { Sludge } \\
\text { Reference }\end{array}$ & $\begin{array}{l}18 \\
15\end{array}$ & $\begin{array}{l}18 \\
15\end{array}$ & $\begin{array}{r}47.34 \\
4.74 \\
\end{array}$ & $\begin{array}{c}2.46-112.5 \\
0.01-51.7\end{array}$ & \\
\hline $\begin{array}{l}\mathrm{NH}_{3}-\mathrm{N} \\
(\mu \mathrm{g} \mathrm{N} / \mathrm{L})\end{array}$ & $\begin{array}{l}\text { Sludge } \\
\text { Reference }\end{array}$ & $\begin{array}{l}18 \\
15 \\
\end{array}$ & $\begin{array}{l}18 \\
15 \\
\end{array}$ & $\begin{array}{c}1581 \\
286.4 \\
\end{array}$ & $\begin{array}{c}7.0-13000 \\
5.0-3310 \\
\end{array}$ & \\
\hline $\begin{array}{l}\text { Total N } \\
(\mathrm{mg} \mathrm{N} / \mathrm{L})\end{array}$ & $\begin{array}{l}\text { Sludge } \\
\text { Reference }\end{array}$ & $\begin{array}{c}9 \\
15\end{array}$ & $\begin{array}{c}9 \\
15\end{array}$ & $\begin{array}{r}63.64 \\
2.47 \\
\end{array}$ & $\begin{array}{c}21.49-108.79 \\
0.064-30.58\end{array}$ & \\
\hline $\begin{array}{l}\text { Total P } \\
(\mathrm{mg} / \mathrm{L})\end{array}$ & $\begin{array}{l}\text { Sludge } \\
\text { Reference }\end{array}$ & $\begin{array}{c}9 \\
15\end{array}$ & $\begin{array}{c}9 \\
15\end{array}$ & $\begin{array}{l}0.655 \\
0.690\end{array}$ & $\begin{array}{c}0.01-3.64 \\
0.01-10\end{array}$ & \\
\hline \multicolumn{4}{|c|}{$A l-Z n(m g / L) 11 / 89-2 / 90$} & $\begin{array}{l}\text { If detect. } \\
\text { limits }=0\end{array}$ & (except Hg) & \\
\hline Al & $\begin{array}{l}\text { Sludge } \\
\text { Reference }\end{array}$ & $\begin{array}{l}14 \\
10\end{array}$ & $\begin{array}{l}14 \\
10\end{array}$ & $\begin{array}{l}0.22 \\
0.04\end{array}$ & $\begin{array}{c}0.01-0.85 \\
0.008-0.076\end{array}$ & \\
\hline B & $\begin{array}{l}\text { Sludge } \\
\text { Reference }\end{array}$ & $\begin{array}{l}14 \\
10\end{array}$ & $\begin{array}{l}14 \\
10\end{array}$ & $\begin{array}{l}0.042 \\
0.021\end{array}$ & $\begin{array}{c}0.02-0.067 \\
0.013-0.032\end{array}$ & \\
\hline $\mathrm{Ca}$ & $\begin{array}{l}\text { Sludge } \\
\text { Reference }\end{array}$ & $\begin{array}{l}14 \\
10\end{array}$ & $\begin{array}{l}14 \\
10\end{array}$ & $\begin{array}{l}84.62 \\
23.95\end{array}$ & $\begin{array}{l}9.68-209.5 \\
3.64-77.41\end{array}$ & \\
\hline $\mathrm{Cd}$ & $\begin{array}{l}\text { Sludge } \\
\text { Reference }\end{array}$ & $\begin{array}{l}14 \\
10\end{array}$ & $\begin{array}{l}0 \\
1\end{array}$ & 0.0005 & & \\
\hline $\mathrm{Cr}$ & $\begin{array}{l}\text { Sludge } \\
\text { Reference }\end{array}$ & $\begin{array}{l}14 \\
10\end{array}$ & $\begin{array}{l}8 \\
4\end{array}$ & $\begin{array}{l}0.029 \\
0.024\end{array}$ & $\begin{array}{l}0.0029-0.063 \\
0.0029-0.053\end{array}$ & \\
\hline $\mathrm{Cu}$ & $\begin{array}{l}\text { Sludge } \\
\text { Reference }\end{array}$ & $\begin{array}{l}14 \\
10\end{array}$ & $\begin{array}{l}7 \\
3\end{array}$ & $\begin{array}{l}0.013 \\
0.031\end{array}$ & $\begin{array}{c}0.006-0.02 \\
0.004-0.059\end{array}$ & \\
\hline $\mathrm{Hg}$ & $\begin{array}{l}\text { Sludge } \\
\text { Reference } \\
\end{array}$ & $\begin{array}{l}6 \\
5 \\
\end{array}$ & $\begin{array}{l}0 \\
0\end{array}$ & & & $\begin{array}{l}4 \\
4\end{array}$ \\
\hline $\mathrm{Fe}$ & $\begin{array}{l}\text { Sludge } \\
\text { Reference } \\
\end{array}$ & $\begin{array}{l}14 \\
10 \\
\end{array}$ & $\begin{array}{c}13 \\
8 \\
\end{array}$ & $\begin{array}{l}0.0224 \\
0.0105\end{array}$ & $\begin{array}{c}.005-0.074 \\
0.0016-0.0453\end{array}$ & \\
\hline $\mathrm{K}$ & $\begin{array}{l}\text { Sludge } \\
\text { Reference } \\
\end{array}$ & $\begin{array}{l}14 \\
10 \\
\end{array}$ & $\begin{array}{l}14 \\
10 \\
\end{array}$ & $\begin{array}{l}3.56 \\
0.752 \\
\end{array}$ & $\begin{array}{l}0.023-12.8 \\
0.061-2.08 \\
\end{array}$ & \\
\hline $\mathrm{Mg}$ & $\begin{array}{l}\text { Sludge } \\
\text { Reference }\end{array}$ & $\begin{array}{l}14 \\
10\end{array}$ & $\begin{array}{l}14 \\
10\end{array}$ & $\begin{array}{l}9.50 \\
1.90\end{array}$ & $\begin{array}{c}0.957-21.34 \\
0.51-5.54\end{array}$ & \\
\hline
\end{tabular}


48

Table 6.4 (continued)

\begin{tabular}{|l|l|c|c|c|c|c|}
\hline & Treatment & $\begin{array}{c}\text { Number of } \\
\text { samples } \\
\text { analyzed }\end{array}$ & \multicolumn{3}{|c|}{ Values above detection limits } & $\begin{array}{c}\text { Range of } \\
\text { detection } \\
\text { limits }\end{array}$ \\
\hline & & & Number & Mean & Range & \\
\hline $\mathrm{Mn}$ & Sludge & 14 & 14 & 0.878 & $0.01-3.26$ & \\
& Reference & 10 & 10 & 0.087 & $0.0008-0.54$ & \\
\hline $\mathrm{Mo}$ & Sludge & 14 & 14 & 0.0130 & $0.0003-0.0438$ & \\
& Reference & 10 & 7 & 0.0079 & $0.0008-0.0214$ & \\
\hline $\mathrm{Na}$ & Sludge & 14 & 14 & 8.77 & $2.49-17.18$ & \\
& Reference & 10 & 10 & 1.33 & $0.81-2.14$ & \\
\hline $\mathrm{Ni}$ & Sludge & 14 & 8 & 0.0110 & $0.0025-0.291$ & \\
& Reference & 10 & 1 & 0.0107 & & \\
\hline $\mathrm{P}$ & Sludge & 14 & 14 & 1.374 & $0.0035-6.699$ & \\
& Reference & 10 & 8 & 0.028 & $0.0035-0.0595$ & \\
\hline $\mathrm{Pb}$ & Sludge & 14 & 2 & 0.0013 & $0.0008-0.0017$ & \\
& Reference & 10 & 1 & 0.0011 & & \\
\hline $\mathrm{Zn}$ & Sludge & 14 & 14 & 0.104 & $0.036-0.198$ & \\
& Reference & 10 & 10 & 0.036 & $0.028-0.056$ & \\
\hline
\end{tabular}


Table 6.5. Soil water metal concentrations at the McCoy and Sycamore sites, from lysimeter samples

(a). McCoy Site, sampled 12/15/87 and 1/19/88.

\begin{tabular}{|c|c|c|c|}
\hline & Treatment & $\begin{array}{l}\text { Number of samples } \\
\text { above detection limit/ } \\
\text { number of samples } \\
\text { analyzed }\end{array}$ & $\begin{array}{l}\text { Mean, mg/L, } \\
\text { assuming values } \\
\text { below detection } \\
\text { limit }=0\end{array}$ \\
\hline $\mathrm{Al}$ & $\begin{array}{l}\text { Sludge } \\
\text { Reference }\end{array}$ & $\begin{array}{l}3 / 4 \\
3 / 4\end{array}$ & $\begin{array}{l}0.114 \\
0.063\end{array}$ \\
\hline As & $\begin{array}{l}\text { Sludge } \\
\text { Reference }\end{array}$ & $\begin{array}{l}0 / 1 \\
0 / 0\end{array}$ & $0 / 0$ \\
\hline B & $\begin{array}{l}\text { Sludge } \\
\text { Reference }\end{array}$ & $\begin{array}{l}0 / 1 \\
0 / 0\end{array}$ & $0 / 0$ \\
\hline $\mathrm{Ba}$ & $\begin{array}{l}\text { Sludge } \\
\text { Reference }\end{array}$ & $\begin{array}{l}9 / 9 \\
6 / 7\end{array}$ & $\begin{array}{l}0.173 \\
0.048\end{array}$ \\
\hline $\mathrm{Be}$ & $\begin{array}{l}\text { Sludge } \\
\text { Reference }\end{array}$ & $\begin{array}{l}0 / 5 \\
0 / 0\end{array}$ & $0 / 0$ \\
\hline $\mathrm{Ca}$ & $\begin{array}{l}\text { Sludge } \\
\text { Reference }\end{array}$ & $\begin{array}{l}9 / 9 \\
7 / 7\end{array}$ & $\begin{array}{r}238.9 \\
26.1\end{array}$ \\
\hline $\mathrm{Cd}$ & $\begin{array}{l}\text { Sludge } \\
\text { Reference }\end{array}$ & $\begin{array}{l}0 / 2 \\
0 / 0\end{array}$ & $0 / 0$ \\
\hline Co & $\begin{array}{l}\text { Sludge } \\
\text { Reference }\end{array}$ & $\begin{array}{l}0 / 2 \\
0 / 0\end{array}$ & $0 / 0$ \\
\hline $\mathrm{Cr}$ & $\begin{array}{l}\text { Sludge } \\
\text { Reference }\end{array}$ & $\begin{array}{l}0 / 2 \\
0 / 0\end{array}$ & $0 / 0$ \\
\hline $\mathrm{Cu}$ & $\begin{array}{l}\text { Sludge } \\
\text { Reference }\end{array}$ & $\begin{array}{l}0 / 2 \\
0 / 0\end{array}$ & $0 / 0$ \\
\hline $\mathrm{Hg}$ & $\begin{array}{l}\text { Sludge } \\
\text { Reference }\end{array}$ & $\begin{array}{l}1 / 1 \\
0 / 0\end{array}$ & $\begin{array}{l}0.089 \\
0 / 0\end{array}$ \\
\hline $\mathrm{Fe}$ & $\begin{array}{l}\text { Sludge } \\
\text { Reference }\end{array}$ & $\begin{array}{l}5 / 8 \\
5 / 6\end{array}$ & $\begin{array}{l}0.030 \\
0.039\end{array}$ \\
\hline $\mathrm{K}$ & $\begin{array}{l}\text { Sludge } \\
\text { Reference }\end{array}$ & $\begin{array}{l}9 / 9 \\
7 / 7\end{array}$ & $\begin{array}{l}0.721 \\
0.763\end{array}$ \\
\hline $\mathrm{Mg}$ & $\begin{array}{l}\text { Sludge } \\
\text { Reference }\end{array}$ & $\begin{array}{l}9 / 9 \\
7 / 7\end{array}$ & $\begin{array}{r}10.52 \\
2.37\end{array}$ \\
\hline Mn & $\begin{array}{l}\text { Sludge } \\
\text { Reference }\end{array}$ & $\begin{array}{l}6 / 8 \\
2 / 2\end{array}$ & $\begin{array}{l}8.200 \\
0.006\end{array}$ \\
\hline $\mathrm{Na}$ & $\begin{array}{l}\text { Sludge } \\
\text { Reference }\end{array}$ & $\begin{array}{l}9 / 9 \\
7 / 7\end{array}$ & $\begin{array}{l}7.28 \\
1.31\end{array}$ \\
\hline $\mathrm{Ni}$ & $\begin{array}{l}\text { Sludge } \\
\text { Reference }\end{array}$ & $\begin{array}{l}0 / 1 \\
0 / 0\end{array}$ & $0 / 0$ \\
\hline
\end{tabular}


50

Table 6.5 (continued)

\begin{tabular}{llcc}
\hline & Treatment & $\begin{array}{c}\text { Number of samples } \\
\text { above detection limit/ } \\
\text { number of samples } \\
\text { analyzed }\end{array}$ & $\begin{array}{c}\text { Mean, mg/L, } \\
\text { assuming values } \\
\text { below detection } \\
\text { limit }=0\end{array}$ \\
\hline $\mathrm{P}$ & Sludge & $0 / 2$ & \\
$\mathrm{Sb}$ & Reference & $0 / 0$ & $0 / 0$ \\
& Sludge & $0 / 2$ & \\
$\mathrm{Si}$ & Reference & $0 / 0$ & $0 / 0$ \\
& Sludge & $5 / 5$ & 3.1 \\
$\mathrm{Sn}$ & Reference & $2 / 2$ & 3.0 \\
& Sludge & $1 / 3$ & 0.015 \\
$\mathrm{Sr}$ & Reference & $0 / 0$ & $0 / 0$ \\
& Sludge & $8 / 8$ & 0.223 \\
$\mathrm{Ti}$ & Reference & $7 / 7$ & 0.060 \\
& Sludge & $1 / 2$ & 0.025 \\
$\mathrm{~V}$ & Reference & $0 / 0$ & $0 / 0$ \\
& Sludge & $5 / 5$ & 0.0852 \\
$\mathrm{Zn}$ & Reference & $2 / 2$ & 0.086 \\
& Sludge & $6 / 7$ & 0.031 \\
& Reference & $5 / 5$ & 0.014
\end{tabular}

(b). Sycamore Site, sampled 03/03/89, 5/12/89, and 6/13/89

$\begin{array}{llcc}\mathrm{Al} & \text { Sludge } & 6 / 10 & 0.031 \\ & \text { Reference } & 5 / 7 & 0.029 \\ \mathrm{~B} & \text { Sludge } & 10 / 10 & 0.024 \\ & \text { Reference } & 6 / 7 & 0.023 \\ \mathrm{Ca} & \text { Sludge } & 10 / 10 & 12.63 \\ & \text { Reference } & 7 / 7 & 4.12 \\ \mathrm{Cd} & \text { Sludge } & 0 / 10 & \\ & \text { Reference } & 0 / 7 & \\ \mathrm{Cr} & \text { Sludge } & 3 / 10 & 0.002 \\ & \text { Reference } & 3 / 7 & 0.001 \\ \mathrm{Cu} & \text { Sludge } & 1 / 10 & 0.001 \\ & \text { Reference } & 1 / 7 & 0.006 \\ \mathrm{Hg} & \text { Sludge } & 3 / 3 & 0.0116 \\ & \text { Reference } & 0 / 0 & \\ \mathrm{Fe} & \text { Sludge } & 4 / 7 & 0.0015 \\ & \text { Reference } & 4 / 7 & 0.0093 \\ \mathrm{~K} & \text { Sludge } & 9 / 10 & 0.537 \\ & \text { Reference } & 5 / 7 & 0.142 \\ \mathrm{Mg} & \text { Sludge } & 10 / 10 & 1.32 \\ & \text { Reference } & 7 / 7 & 0.87\end{array}$




\begin{tabular}{|c|c|c|c|}
\hline & Treatment & $\begin{array}{c}\text { Number of samples } \\
\text { above detection limit/ } \\
\text { number of samples } \\
\text { analyzed }\end{array}$ & $\begin{array}{l}\text { Mean, mg/h, } \\
\text { assuming values } \\
\text { below detection } \\
\text { limit }=0\end{array}$ \\
\hline $\mathrm{Al}$ & $\begin{array}{l}\text { Sludge } \\
\text { Reference }\end{array}$ & $\begin{array}{c}6 / 10 \\
5 / 7\end{array}$ & $\begin{array}{l}0.031 \\
0.029\end{array}$ \\
\hline B & $\begin{array}{l}\text { Sludge } \\
\text { Reference }\end{array}$ & $\begin{array}{c}10 / 10 \\
6 / 7\end{array}$ & $\begin{array}{l}0.024 \\
0.023\end{array}$ \\
\hline $\mathrm{Mn}$ & $\begin{array}{l}\text { Sludge } \\
\text { Reference }\end{array}$ & $\begin{array}{c}10 / 10 \\
7 / 7\end{array}$ & $\begin{array}{l}0.093 \\
0.051\end{array}$ \\
\hline Mo & $\begin{array}{l}\text { Sludge } \\
\text { Reference }\end{array}$ & $\begin{array}{c}2 / 10 \\
3 / 7\end{array}$ & $\begin{array}{l}0.0075 \\
0.0083\end{array}$ \\
\hline $\mathrm{Na}$ & $\begin{array}{l}\text { Sludge } \\
\text { Reference }\end{array}$ & $\begin{array}{c}10 / 10 \\
7 / 7\end{array}$ & $\begin{array}{l}1.40 \\
1.07\end{array}$ \\
\hline $\mathrm{Ni}$ & $\begin{array}{l}\text { Sludge } \\
\text { Reference }\end{array}$ & $\begin{array}{c}6 / 10 \\
1 / 7\end{array}$ & $\begin{array}{l}0.0064 \\
0.0004\end{array}$ \\
\hline$P$ & $\begin{array}{l}\text { Sludge } \\
\text { Reference }\end{array}$ & $\begin{array}{c}6 / 10 \\
3 / 7\end{array}$ & $\begin{array}{l}0.0172 \\
0.0072\end{array}$ \\
\hline $\mathrm{Pb}$ & $\begin{array}{l}\text { Sludge } \\
\text { Reference }\end{array}$ & $\begin{array}{l}1 / 10 \\
2 / 7\end{array}$ & $\begin{array}{l}0.0006 \\
0.0035\end{array}$ \\
\hline $\mathrm{Zn}$ & $\begin{array}{l}\text { Sludge } \\
\text { Reference }\end{array}$ & $\begin{array}{c}10 / 10 \\
7 / 7\end{array}$ & $\begin{array}{l}0.0486 \\
0.0411\end{array}$ \\
\hline
\end{tabular}

Table 6.6. Radionuclides measured in lysimeters at the Pine Plantation Site at the end of the sludge application period (6/88 through 6/89), and one sample before sludge application began

\begin{tabular}{ccccc}
\hline \multicolumn{5}{c}{ Radionuclides in soil water } \\
\hline $\begin{array}{c}\text { Plot } \\
\text { number }\end{array}$ & Treatment of plot & $\begin{array}{c}\text { Sample } \\
\text { date }\end{array}$ & $\begin{array}{c}{ }^{137} \mathrm{Cs} \\
(\mathbf{p C i} / \mathrm{L})\end{array}$ & $\begin{array}{c}{ }^{60} \mathrm{Co} \\
(\mathbf{p C i} / \mathrm{L})\end{array}$ \\
\hline 3 & Sludge only & $07 / 05 / 89$ & $<2.6$ & $<2.05$ \\
6 & Sludge only & $07 / 05 / 89$ & $<2.6$ & 2.9 \\
8 & Sludge only & $07 / 05 / 89$ & $<2.2$ & $<2.9$ \\
$12 \& 13$ & Reference & $07 / 05 / 89$ & $<2.3$ & $<2.5$ \\
8 & "Sludge only" & $10 / 14 / 87$ & $<5.4$ & $<5.4$ \\
\hline
\end{tabular}




\section{WELLS}

Ground water sampling was done at the Pine Plantation Site, where five Resource Conservation and Recovery Act-type groundwater wells (EPA, 1986) were installed prior to sludge application. Wells numbered 1133 and 1134 were upgradient of the sludge application area and can be considered reference wells. One of these, 1133, was at $7 \mathrm{~m}$, sampling at the first soil/rock interface, and one, 1134, was at $57 \mathrm{~m}$ deep, at the major bedrock level. Wells numbered 1130,1131, and 1132 were downgradient from sludge application. Two were at the edge of the application area (1131 and 1132), and one was about $100 \mathrm{~m}$ further downgradient of the area (1130). These three wells were all 7-8 m deep, to intercept the first major soil/rock interface where flow was likely to occur. Locations of these wells are shown in Fig. 3.4. Except for well No. 1134, these wells were relatively shallow, and, because of the Karst geology of the region, might show some degree of infiltration of soil water through fractures and solution cavities in the underlying rock (Van Miegroet, et al., 1989). (It should be noted programmatically that sludge land application does not occur where Karst formations exist, unless at least $15 \mathrm{~cm}$ of cover soil is present, based on background studies which show that the majority of sludge constituents, for example, metals, are contained in the upper $15 \mathrm{~cm}$ of receiving sludge site soils.) Sampling was conducted approximately monthly during, and for up to 19 months after the sludge application period. During the dry season (July-December), not all wells had enough water to sample, and total number of samples per well was variable.

Results of the water chemistry, nutrient analyses, and fecal coliform counts, with mean, median, and range of values for each well are shown in Table 7.1. Table 7.2 has metals concentrations for each well, including mean, range, and number of samples with concentrations above the detection limits for the metal. Table 7.3 shows the radionuclides measured in wells at this site several times during and after sludge application. Most of the downgradient well samples were comparable to the samples in the upgradient wells. The exception was well No. 1131, which on some occasions had higher levels of fecal coliform, $\mathrm{NO}_{3}$, total $\mathrm{N}$, and perhaps radionuclides on one or two occasions. This well was directly in the sludge application area, was quite shallow (only $20 \mathrm{ft}$ deep), and may have been sampling soil water directly through a fracture. Peak nitrate concentrations in well No. 1132 may be seen clearly in Fig. 7.1, which illustrates the concentration of nitrate in all wells plotted against time. Despite the occasional high nitrate concentrations in well No. 1131, the peak concentration $(6.07 \mathrm{mg} / \mathrm{L})$ was still well below the drinking water standard of $10 \mathrm{mg} / \mathrm{L}$. Drinking water standards for metals are also shown in Table 7.2 alongside the data from well 1131 for comparison. These concentrations were not exceeded for well No. 1131, even though it had the strongest evidence for sludge infiltration based on nitrate and coliform levels. Wells 1130 and 1132 , however, were above the manganese standard of $0.05 \mathrm{mg} / \mathrm{L}$ on several dates, but this was also true of well No. 1133, which was upgradient of the application field, suggesting that sludge application was not a factor. 
Table 7.1. Groundwater chemistry at the Pine Plantation Site

\begin{tabular}{|c|c|c|c|c|}
\hline & Mean & Median & Range & $\begin{array}{c}\text { Number of samples } \\
\text { anatyzod }\end{array}$ \\
\hline \multicolumn{5}{|c|}{ Well Na 1130 (downgradient) } \\
\hline $\begin{array}{l}\text { Fecal coliform } \\
\text { Conductivity } \\
\text { Allalinity } \\
\text { pH } \\
\mathrm{NO}_{3} \\
\mathrm{NH}_{4} \\
\text { Total N } \\
\text { Total P }\end{array}$ & $\begin{array}{c}0 \\
212.1 \\
2.39 \\
7.66 \\
0.327 \\
10.9 \\
0.43 \\
0.010\end{array}$ & $\begin{array}{c}0 \\
220.5 \\
2.36 \\
7.57 \\
0.298 \\
7.17 \\
0.345 \\
0.011\end{array}$ & $\begin{array}{c}0-0 \\
31-250 \\
1.92-3.18 \\
7.0-9.0 \\
0.21-0.72 \\
1.6-27.0 \\
0.15-1.28 \\
0.005-0.012\end{array}$ & $\begin{array}{c}19 \\
32 \\
31 \\
31 \\
32 \\
19 \\
9 \\
9\end{array}$ \\
\hline \multicolumn{5}{|c|}{ Well No. 1131 (downgradient) } \\
\hline $\begin{array}{l}\text { Fecal coliform } \\
\text { Conductivity } \\
\text { Alkalinity } \\
\text { pH } \\
\mathrm{NO}_{3} \\
\mathrm{NH}_{4} \\
\text { Total N } \\
\text { Total P }\end{array}$ & $\begin{array}{l}779 \\
193.6 \\
1.78 \\
7.0 \\
2.24 \\
10.44 \\
2.61 \\
0.014\end{array}$ & $\begin{array}{l}14 \\
198 \\
1.77 \\
7.1 \\
1.84 \\
7.02 \\
2.134 \\
0.014\end{array}$ & $\begin{array}{c}1-9800 \\
31-248 \\
0.84-2.64 \\
6.2-7.5 \\
0.23-6.07 \\
0.74-29.0 \\
0.38-6.88 \\
0.008-0.027\end{array}$ & $\begin{array}{l}13 \\
31 \\
30 \\
30 \\
29 \\
17 \\
8 \\
8\end{array}$ \\
\hline \multicolumn{5}{|c|}{ Well No. 1132 (downgradient) } \\
\hline $\begin{array}{l}\text { Fecal coliform } \\
\text { Conductivity } \\
\text { Alkalinity } \\
\text { pH } \\
\mathrm{NO}_{3} \\
\mathrm{NH}_{4} \\
\text { Total N } \\
\text { Total P }\end{array}$ & $\begin{array}{c}1.58 \\
29.7 \\
0.28 \\
5.73 \\
0.68 \\
10.3 \\
0.713 \\
0.009\end{array}$ & $\begin{array}{c}0 \\
28.8 \\
0.17 \\
5.75 \\
0.69 \\
10.5 \\
0.739 \\
0.008\end{array}$ & $\begin{array}{c}0-10 \\
7-50 \\
0.01-1.48 \\
5.03-6.45 \\
0.43-0.81 \\
0.01-25.2 \\
0.61-0.77 \\
0.003-0.014\end{array}$ & $\begin{array}{l}19 \\
30 \\
24 \\
29 \\
28 \\
17 \\
8 \\
8\end{array}$ \\
\hline \multicolumn{5}{|c|}{ WeI No. 1133 (upgodient) } \\
\hline $\begin{array}{l}\text { Fecal coliform } \\
\text { Conductivity } \\
\text { Alkalinity } \\
\text { pH } \\
\mathrm{NO}_{3} \\
\mathrm{NH}_{4} \\
\text { Total N } \\
\text { Total P }\end{array}$ & $\begin{array}{c}2.3 \\
17.8 \\
0.16 \\
5.35 \\
0.193 \\
17.41 \\
0.10 \\
0.018\end{array}$ & $\begin{array}{c}0 \\
17.2 \\
0.09 \\
5.30 \\
0.144 \\
10.70 \\
0.092 \\
0.017 \\
\end{array}$ & $\begin{array}{c}0-16 \\
5-33.7 \\
0.06-0.60 \\
4.96-5.81 \\
0.073-0.67 \\
5.09-76.8 \\
0.08-0.13 \\
0.009-0.031\end{array}$ & $\begin{array}{c}10 \\
12 \\
7 \\
12 \\
12 \\
10 \\
3 \\
4\end{array}$ \\
\hline \multicolumn{5}{|c|}{ Well No. 1134 (upgradient) } \\
\hline $\begin{array}{l}\text { Fecal coliform } \\
\text { Conductivity } \\
\text { Alkalinity } \\
\text { pH } \\
\mathrm{NO}_{3} \\
\mathrm{NH}_{4} \\
\text { Total N } \\
\text { Total P }\end{array}$ & $\begin{array}{c}0.5 \\
274 \\
2.85 \\
7.88 \\
0.326 \\
11.004 \\
0.343 \\
0.011\end{array}$ & $\begin{array}{c}0 \\
285 \\
2.96 \\
7.87 \\
0.295 \\
10.00 \\
0.392 \\
0.009\end{array}$ & $\begin{array}{c}0-2 \\
46-310 \\
0.02-3.34 \\
7.51-8.25 \\
0.004-1.99 \\
3.28-27.61 \\
0.02-0.45 \\
0.003-0.021\end{array}$ & $\begin{array}{l}16 \\
31 \\
30 \\
30 \\
31 \\
19 \\
8 \\
8\end{array}$ \\
\hline
\end{tabular}

${ }^{\circ}$ Some samples had inadequate volume to perform all analyses. Data reflect sample collections during and for 19 months after sludge application. Wells numbered 1133 and 1134 can be considered upgradient of the sludge application area (reference wells), and those numbered 1130,1131, and 1132 can be considered downgradient. Units for fecal coliform are colonies $/ 100 \mathrm{~mL}$; for conductivity, $\mu \mathrm{mhos} / \mathrm{cm}$; for alkalinity meg/L; for $\mathrm{NO}_{3} \mathrm{mg} / \mathrm{L}$; for $\mathrm{NH}_{4}$ $\mu \mathrm{g} / \mathrm{L}$; for total $\mathrm{N} \mathrm{mg} / \mathrm{L}$; and for total $\mathrm{P}, \mathrm{mg} / \mathrm{L}$. 
Table 7.2. Metal concentrations ( $\mathrm{mg} / \mathrm{L}$ ) in wells at the Pine Plantation during and for 9 months after sludge application ${ }^{\alpha}$

\begin{tabular}{|c|c|c|c|c|c|c|}
\hline & Mean & Range & Detection limit & $\begin{array}{l}\text { Number of } \\
\text { samples above } \\
\text { detection limit }\end{array}$ & $\begin{array}{l}\text { Number } \\
\text { of samples } \\
\text { analyzed }\end{array}$ & DWs $^{b}$ \\
\hline \multicolumn{7}{|c|}{ Well No. 1130 (downgradient) } \\
\hline $\begin{array}{l}\mathrm{Ag} \\
\mathrm{As} \\
\mathrm{Ba} \\
\mathrm{Ca} \\
\mathrm{Cd} \\
\mathrm{Cr} \\
\mathrm{Cu} \\
\mathrm{Fe} \\
\mathrm{K} \\
\mathrm{Mg} \\
\mathrm{Mn} \\
\mathrm{Na} \\
\mathrm{Pb} \\
\mathrm{Se} \\
\mathrm{Sr} \\
\mathrm{Zn}\end{array}$ & $\begin{array}{l}<0.006 \\
<0.06 \\
0.032 \\
25.3 \\
<0.007 \\
<0.007 \\
<0.02 \\
<0.048 \\
<1.88 \\
12.7 \\
<0.007 \\
<2.5 \\
<0.05 \\
<0.06 \\
0.023 \\
<0.02\end{array}$ & $\begin{array}{c}0.014-0.048 \\
16-31 \\
\\
<0.004-0.023 \\
0.0006-0.07 \\
<0.02-6.09 \\
0.02-16 \\
0.004-0.018 \\
<0.5-5.0 \\
\\
\\
0.018-0.035 \\
0.006-0.046\end{array}$ & $\begin{array}{c}0.006 \\
0.06 \\
\\
0.001-0.007 \\
0.004-0.01 \\
0.005-0.02 \\
0.003-0.02 \\
0.02 \\
0.002-0.04 \\
0.5 \\
0.01-0.05 \\
0.01-0.06 \\
0.005-0.008\end{array}$ & $\begin{array}{r}0 \\
0 \\
5 \\
10 \\
0 \\
7 \\
0 \\
0 \\
6 \\
10 \\
6 \\
8 \\
0 \\
0 \\
4 \\
8\end{array}$ & $\begin{array}{r}7 \\
7 \\
5 \\
10 \\
10 \\
10 \\
10 \\
10 \\
8 \\
10 \\
10 \\
10 \\
8 \\
8 \\
4 \\
10\end{array}$ & \\
\hline \multicolumn{7}{|c|}{ Well No. 1131 (downgradient) } \\
\hline $\begin{array}{l}\mathrm{Ag} \\
\mathrm{As} \\
\mathrm{Ba} \\
\mathrm{Ca} \\
\mathrm{Cd} \\
\mathrm{Cr} \\
\mathrm{Cu} \\
\mathrm{Fe} \\
\mathrm{K} \\
\mathrm{Mg} \\
\mathrm{Mn} \\
\mathrm{Na} \\
\mathrm{Pb} \\
\mathrm{Se} \\
\mathrm{Sr} \\
\mathrm{Zn} \\
\end{array}$ & $\begin{array}{c}<0.006 \\
<0.06 \\
0.109 \\
19.3 \\
<0.007 \\
<0.004 \\
<0.018 \\
<0.056 \\
1.6 \\
11.1 \\
<0.007 \\
<6.6 \\
<0.05 \\
<0.06 \\
0.028 \\
<0.064 \\
\end{array}$ & $\begin{array}{c}0.04-0.18 \\
0.23-27.9 \\
<0.004-0.006 \\
\\
0.003-0.14 \\
1.2-2.1 \\
5.8-14.0 \\
<0.002-0.023 \\
<0.5-12 \\
. \\
\\
0.024-0.030 \\
0.014-0.215 \\
\end{array}$ & $\begin{array}{c}0.006 \\
0.06 \\
\\
0.001-0.007 \\
0.005 \\
0.001-0.01 \\
0.003-0.02 \\
\\
0.002 \\
0.5 \\
0.01-0.05 \\
0.01-0.06 \\
\\
0.008-0.05 \\
\end{array}$ & $\begin{array}{r}0 \\
0 \\
4 \\
10 \\
0 \\
4 \\
0 \\
8 \\
8 \\
10 \\
7 \\
9 \\
0 \\
0 \\
4 \\
7 \\
\end{array}$ & $\begin{array}{r}6 \\
6 \\
4 \\
4 \\
10 \\
10 \\
10 \\
10 \\
10 \\
8 \\
10 \\
10 \\
10 \\
10 \\
8 \\
4 \\
9 \\
\end{array}$ & $\begin{array}{l}0.05 \\
0.05 \\
1.0 \\
\\
0.01 \\
0.05 \\
1.0 \\
0.3\end{array}$ \\
\hline
\end{tabular}




\begin{tabular}{|c|c|c|c|c|c|c|}
\hline & Mean & Range & Detection limit & $\begin{array}{l}\text { Number of } \\
\text { samples above } \\
\text { detection limit }\end{array}$ & $\begin{array}{l}\text { Number } \\
\text { of samples } \\
\text { analyzed }\end{array}$ & $\mathrm{DWS}^{\mathbf{b}}$ \\
\hline \multicolumn{7}{|c|}{ Well No. 1132 (downgradient) } \\
\hline $\begin{array}{l}\mathrm{Ag} \\
\mathrm{As} \\
\mathrm{Ba} \\
\mathrm{Ca} \\
\mathrm{Cd} \\
\mathrm{Cr} \\
\mathrm{Cu} \\
\mathrm{Fe} \\
\mathrm{K} \\
\mathrm{Mg} \\
\mathrm{Mn} \\
\mathrm{Na} \\
\mathrm{Pb} \\
\mathrm{Se} \\
\mathrm{Sr} \\
\mathrm{Zn}\end{array}$ & $\begin{array}{c}<0.006 \\
<0.06 \\
0.089 \\
1.43 \\
<0.007 \\
<0.005 \\
<0.012 \\
<0.128 \\
1.15 \\
0.33 \\
0.086 \\
<5.7 \\
<0.05 \\
<0.06 \\
0.0097 \\
0.055\end{array}$ & $\begin{array}{c}0.057-0.15 \\
0.048-45 \\
\\
<0.004-0.006 \\
0.007-0.02 \\
0.004-0.53 \\
0.18-5.46 \\
0.23-0.46 \\
0.01-0.21 \\
<0.5-9.1 \\
0.01-<0.05 \\
\\
0.0066-0.012 \\
0.009-0.116\end{array}$ & $\begin{array}{c}0.006 \\
0.06 \\
\\
0.001-0.007 \\
0.004-0.005 \\
0.007-0.02 \\
0.003-0.02 \\
\\
\\
0.01-0.05 \\
0.01-0.06\end{array}$ & $\begin{array}{r}0 \\
0 \\
0 \\
10 \\
0 \\
3 \\
3 \\
6 \\
8 \\
10 \\
10 \\
8 \\
1 \\
0 \\
5 \\
10\end{array}$ & $\begin{array}{r}7 \\
7 \\
5 \\
10 \\
10 \\
10 \\
10 \\
10 \\
8 \\
10 \\
10 \\
10 \\
10 \\
8 \\
5 \\
10\end{array}$ & $\cdot$ \\
\hline \multicolumn{7}{|c|}{ Well No. 1133 (upgradient) } \\
\hline $\begin{array}{l}\mathrm{Ag} \\
\mathrm{As} \\
\mathrm{Ba} \\
\mathrm{Ca} \\
\mathrm{Cd} \\
\mathrm{Cr} \\
\mathrm{Cu} \\
\mathrm{Fe} \\
\mathrm{K} \\
\mathrm{Mg} \\
\mathrm{Mn} \\
\mathrm{Na} \\
\mathrm{Pb} \\
\mathrm{Se} \\
\mathrm{Sr} \\
\mathrm{Zn}\end{array}$ & $\begin{array}{c}<0.006 \\
<0.06 \\
0.089 \\
1.73 \\
<0.007 \\
<0.02 \\
<0.015 \\
<0.011 \\
1.22 \\
0.51 \\
0.10 \\
1.05 \\
<0.05 \\
<0.06 \\
0.01 \\
0.054\end{array}$ & $\begin{array}{c}0.93-2.78 \\
\\
0.002-0.046 \\
<0.005-0.015 \\
0.006-0.02 \\
0.71-2.17 \\
0.34-0.91 \\
0.06-0.14 \\
<0.05-1.2 \\
\\
0.01-0.11\end{array}$ & $\begin{array}{c}0.006 \\
0.06 \\
\\
0.007 \\
0.004-0.006 \\
0.005 \\
0.003-0.01 \\
\\
\\
0.5 \\
0.001-0.05 \\
0.001-0.06\end{array}$ & $\begin{array}{l}0 \\
0 \\
1 \\
4 \\
0 \\
0 \\
2 \\
1 \\
3 \\
3 \\
4 \\
4 \\
2 \\
0 \\
0 \\
1 \\
3\end{array}$ & $\begin{array}{l}2 \\
2 \\
1 \\
4 \\
4 \\
4 \\
4 \\
4 \\
3 \\
4 \\
4 \\
3 \\
3 \\
3 \\
1 \\
1 \\
3\end{array}$ & \\
\hline
\end{tabular}


Table 7.2 (continued)

\begin{tabular}{|c|c|c|c|c|c|c|}
\hline & Mean & Range & Detection limit & $\begin{array}{l}\text { Number of } \\
\text { samples above } \\
\text { detection limit }\end{array}$ & $\begin{array}{l}\text { Number } \\
\text { of samples } \\
\text { analyzed }\end{array}$ & Dws \\
\hline \multicolumn{7}{|c|}{ Well No. 1134 (upgradient) } \\
\hline $\mathrm{Ag}$ & $<0.006$ & & 0.006 & 0 & 5 & \\
\hline As & $<0.06$ & $<0.05-0.065$ & 0.06 & 1 & 5 & \\
\hline $\mathrm{Ba}$ & 0.073 & $0.037-0.12$ & & 4 & 4 & \\
\hline $\mathrm{Ca}$ & 33.6 & $20.0-45.0$ & & 9 & 9 & $\cdot$ \\
\hline $\mathrm{Cd}$ & $<0.007$ & & $0.001-0.007$ & 0 & 9 & \\
\hline $\mathrm{Cr}$ & $<0.0045$ & $0.0035-0.0053$ & & 4 & 9 & \\
\hline $\mathrm{Cu}$ & $<0.01$ & & $0.005-0.01$ & 0 & 9 & \\
\hline $\mathrm{Fe}$ & $<0.14$ & $0.01-0.65$ & $0.003-0.18$ & 5 & 9 & \\
\hline $\mathbf{K}$ & 1.3 & $<0.05-3.41$ & 0.05 & 6 & 7 & \\
\hline $\mathrm{Mg}$ & 19 & $17-21$ & & 8 & 8 & \\
\hline $\mathrm{Mn}$ & $<0.013$ & $<0.002-0.036$ & 0.002 & 4 & 9 & \\
\hline $\mathrm{Na}$ & $<1$ & $<0.5-1.34$ & 0.5 & 1 & 10 & \\
\hline $\mathrm{Pb}$ & $<0.05$ & $0.026-<0.05$ & $0.01-0.05$ & 1 & 10 & \\
\hline $\mathrm{Se}$ & $<0.06$ & & $0.01-0.06$ & 0 & 6 & \\
\hline $\mathrm{Sr}$ & 0.0578 & $0.033-0.094$ & & 4 & 4 & \\
\hline $\mathrm{Zn}$ & $<0.021$ & $0.003-0.050$ & 0.008 & 8 & 9 & \\
\hline
\end{tabular}

${ }^{a}$ Analyses were by ICP. Hg was analyzed only twice for each well (5/89 and 7/89) and was below the detection limit of 0.0005 for all samples. Total $U$ was analyzed one time for each well, six months after application ended $(6 / 90)$, and was below the detection limit of 0.001 for all samples. Means are listed as " $<$ " the maximum detection limit (different samples were sent to labs with different detection limits) if all values were below the detection limit (no range for concentrations given), or as " $<$ " the mean of the detectable concentrations if some but not all of the values were below the detection limits for that element. Well identities are described in the text and in Table 7.1. Detection limits (or ranges of them) are given if some samples concentrations were reported as below the detection limits.

${ }^{b}$ State and federal drinking water standards, $\mathrm{mg} / \mathrm{L}$. 
Table 73. Radionuclides measured in wells at the Pine Plantation site during and after sludge application (application period 6/88 through 6/89)

(Well 1134' was a replicate sample)

\begin{tabular}{|c|c|c|c|c|}
\hline \multicolumn{5}{|c|}{ Radionuclides in water } \\
\hline Well number & Sample date & $\begin{array}{l}\text { Cs } 137 \\
\text { (pCin) }\end{array}$ & $\begin{array}{c}\text { Co } 60 \\
\text { (pCi/L) }\end{array}$ & $\begin{array}{c}\text { Uranium } \\
\text { (ppm) }\end{array}$ \\
\hline 1130 & $06 / 23 / 88$ & 5.8 & $<3.7$ & \\
\hline 1130 & $11 / 15 / 88$ & $<5.8$ & $<9.4$ & \\
\hline 1130 & $06 / 22 / 89$ & & & 0.040 \\
\hline 1130 & $02 / 05 / 90$ & & & 0.039 \\
\hline 1130 & $05 / 07 / 90$ & & & $<0.001$ \\
\hline 1131 & $06 / 23 / 88$ & 9.9 & $<7.3$ & \\
\hline 1131 & $11 / 15 / 88$ & $<5.3$ & $<6.3$ & \\
\hline 1131 & $06 / 22 / 89$ & $<2.1$ & $<1.8$ & 0.060 \\
\hline 1131 & $02 / 05 / 90$ & & & 0.433 \\
\hline 1131 & 05/07/90 & & & $<0.001$ \\
\hline 1132 & $11 / 15 / 88$ & $<3.0$ & $<3.0$ & \\
\hline 1132 & $06 / 22 / 89$ & $<2.2$ & $<2.1$ & 0.100 \\
\hline 1132 & $02 / 05 / 90$ & & & 0.008 \\
\hline 1132 & $05 / 07 / 90$ & & & $<0.001$ \\
\hline 1133 & $06 / 22 / 89$ & $<2.5$ & $<2.2$ & \\
\hline 1133 & $02 / 05 / 90$ & & & 0.148 \\
\hline 1133 & $05 / 07 / 90$ & & & 0.001 \\
\hline 1134 & $11 / 15 / 88$ & 4.7 & $<5.5$ & \\
\hline 1134 & $06 / 22 / 89$ & $<2.4$ & $<2.3$ & 0.070 \\
\hline 1134 & $02 / 05 / 90$ & & & 0.163 \\
\hline 1134 & $05 / 07 / 90$ & & & $<0.001$ \\
\hline 1134 & $05 / 07 / 90$ & & & $<0.001$ \\
\hline
\end{tabular}




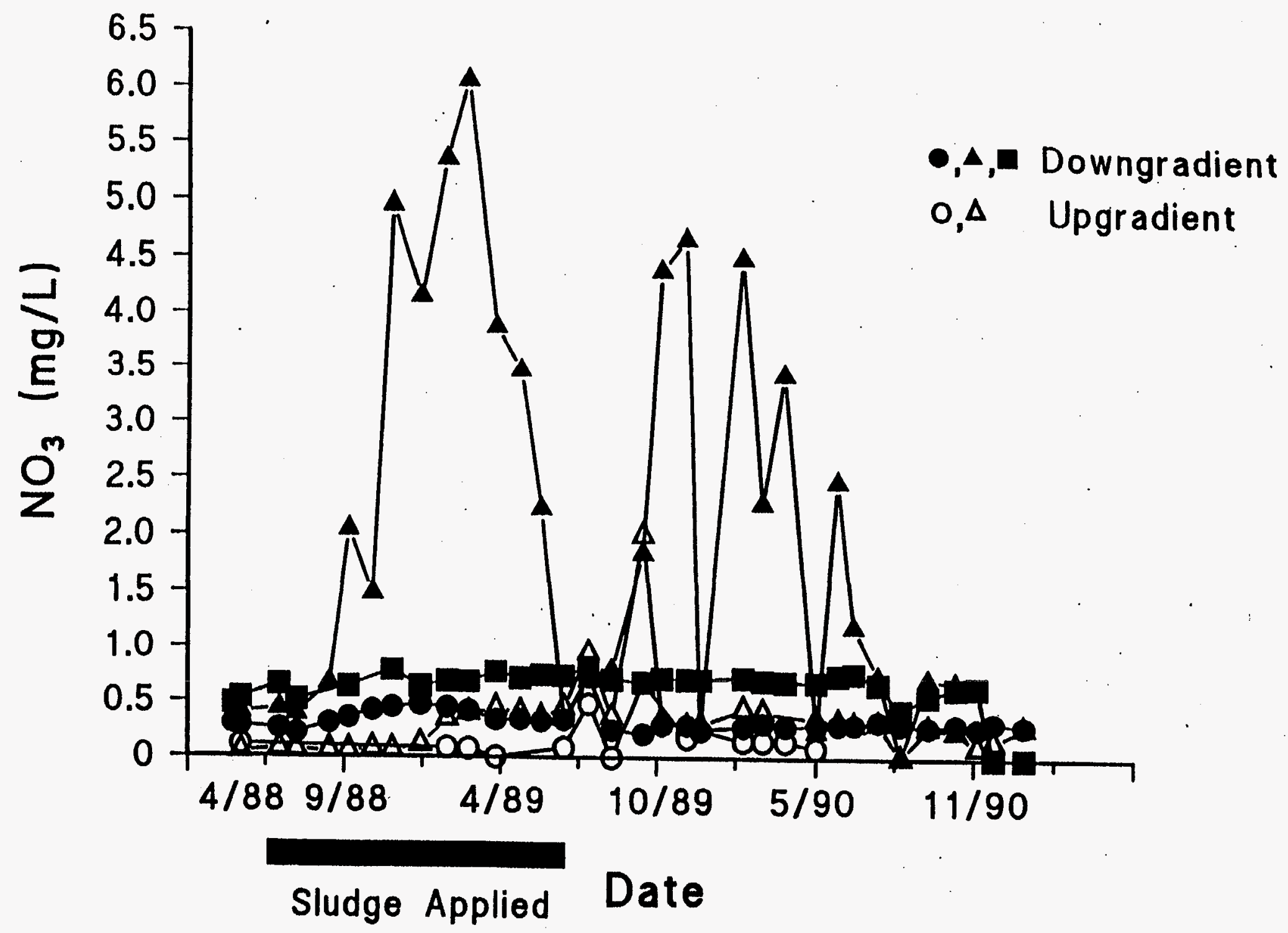

Fig. 7.1. Nitrate in wells at the Pine Plantation Site before, during, and after the sludge application period. Solid symbols indicate downgradient wells: circles = Well No. 1130; triangles = Well No. 1131; squares = Well No. 1132. Open symbols indicate upgradient, or reference, wells: circles $=$ Well No. 1133 ; triangles $=$ Well No. 1134 . Not that only Well No. 1131 showed significantly elevated nitrate levels. The drinking standard for nitrate is $10 \mathrm{mg} / \mathrm{L}$. 


\section{SURFACE RUNOFF}

\subsection{METHODS OF SAMPLNNG}

Surface runoff sampling began in February 1987, with grab samples taken from the McCoy Site (application ended there in 1986) and from the active application area in the Rogers Site. Later sampling at these and other sites included sample compositors (Coshocton wheel mechanical proportional-flow samplers) to provide integrated flow samples as well as grab samples. Samples were taken during or after rain events from surface rivulets, overland flow, standing pools, and creeks running into and out of some sites. Some rain events yielded insufficient samples at some sampling locations, and incomplete data sets occasionally resulted (e.g., no reference at that site for that date, or no sample from the treatment area, or a compositor sample from the treatment area, but only a grab sample from the reference.)

Runoff collection at the McCoy Site was conducted from February 1987 through March 1988. Sampling at the Rogers Site continued from February 1987 to February 1990. Samples were collected at the Cottonwood plantation site from August 1989 through December 1990 and at the Pine Plantation from July 1988 through February 1990. Limited sampling was conducted at the Watson Road Site from October through December 1990 and at the Scarboro Site in December 1990.

Samples were analyzed routinely for water chemistry and nutrients, and for metals by ICP. Metals analysis was performed on the total, unfiltered samples, and, in some cases, the soluble portion or the particulate portion. Additional analyses for other metals, fecal coliform bacteria, BOD, and radionuclides were performed several times. Duplicate samples were analyzed on several occasions and demonstrated good reproducibility of analytical results. Because of the inconsistent nature of the storm events and associated runoff, collections were not always possible from equivalent reference and sample runoff streams. As a result, rigorous statistical analysis was not possible, not all of the data were useful for comparative purposes on a storm-by-storm basis, and the number of samples contributing to each mean was variable.

\subsection{RESULTS}

Tables 8.1 through 8.4 summarize the water chemistry and nutrient concentrations in runoff at four sites and describe the sampling locations. These tables allow comparison of reference and treatment area runoff samples in several ways. For the Cottonwood Site, Table 8.1 gives mean, range, number of samples, and number of paired (both samples available) storm events when the concentration, conductivity, and so on, exceeded those in the reference stream. Values were designated as elevated if they were greater than $110 \%$ of the reference value for that storm. These data show some elevation in soluble components, particularly in the South Creek samples, which consisted only of water running through the site, whereas the North Creek samples were taken where the runoff had been joined by an additional creek and had less tendency to be elevated.

Table 8.2 gives the mean and range for all the treatment streams at the Watson Road Site and indicates which treatment area sample locations, if any, were consistently higher for a particular variable. For example, the $\mathrm{W} 1$ sample was consistently higher in $\mathrm{NO}_{3}$, total $\mathrm{N}$, 
soluble reactive $\mathrm{P}$, and total suspended solids than either of the other treatment creeks, and higher than the reference; whereas, W2 and W3 were consistently higher in conductivity and alkalinity than Wl or the reference. In general, the treatment creek(s) not listed as having consistently higher values were comparable to the reference for that component, or, in the case of total $\mathbf{P}$, all three creeks were similarly elevated.

Table 8.3 gives mean, range, and number of storm events when concentrations in the Rogers treatment area runoff exceeded those in comparable reference runoff, separating grab samples from compositor samples and a "worst case" sample from a standing pool in the treatment area. The number of samples analyzed and number compared reflect the fact that there was not always enough water flowing to collect samples at all positions, or there was no standing water on a particular date. Runoff samples from the Rogers treatment area were generally higher in soluble nutrients like $\mathrm{NO}_{3}, \mathrm{NH}_{4}$, total $\mathrm{N}$, and $\mathrm{P}$, and were higher in conductivity, although they were not necessarily higher in total suspended solids when compared for the same date. Compositor samples from the treatment area tended to be higher in $\mathrm{NH}_{4}$ than grab samples, but lower in $\mathrm{NO}_{3}$ and total $\mathrm{N}$ and $\mathrm{P}$. These patterns were not observed in the reference samples. Another pattern observed in the grab samples was a gradual decline in runoff of all soluble nutrients after sludge application ended until the last samples-which were taken in the spring of 1990 , slightly more than a year after application ended-were not appreciably different from the reference samples. The samples from the standing pool ranged from much higher to lower than or very similar to the other treatment samples.

Table 8.4 presents runoff data from the Pine Plantation in three ways: (a) mean and standard deviation for the four principal sample locations at the Pine Site (grab and compositor), (b) data from all grab sample locations on two typical dates, and (c) all compositor and grab samples for two other dates. Treatment samples were on average (Table 8.4(a) higher in conductivity and in total suspended solids in all measures of $\mathrm{N}$ and $\mathrm{P}$. Samples in (b) and (c) are arranged from upgradient downward, with P3 and P4 being references upgradient of the site; Pl, P2, and 1132SP (a spring or surface flow) in the treatment area; and " $\mathrm{C}$ at $\mathrm{C}^{\prime \prime}$ and $\mathrm{P} 6$ downstream, with possible dilution. For the most part, concentrations (or other measures) can be seen to increase moving down the table into the treatment samples and decrease downstream with dilution as expected.

A one-time grab sample at the Scarboro Site (December 17, 1990) found both treatment samples higher in soluble reactive phosphorus than the reference sample ( 2.8 and 8.5 versus $0.033 \mathrm{mg} / \mathrm{L}$ ), somewhat lower in alkalinity ( 0.3 and 0.46 versus $1.12 \mu \mathrm{mhos} / \mathrm{cm}$ ), but no different in suspended solids, $\mathrm{pH}$, or conductivity.

Tables 8.5 through 8.8 present metals concentrations in runoff from the McCoy, Rogers, Pine, and Cottonwood sites, all arranged by sample collection date to allow comparison of concentrations in reference and treatment samples for a particular storm. For the McCoy and Rogers sites, not all dates sampled are presented, but several dates with reasonably complete data were chosen as examples. Compositor as well as grab samples are included where available (Rogers and Pine), and total, soluble, and particulate fractions are all listed where available (McCoy and Rogers sites). Mercury concentrations in runoff from the Rogers Site are presented separately in Table 8.9.

Table 8.10 presents radionuclide data from four sites, and Table 8.11 contains BOD and fecal coliform data arranged by sampling location and date at three sites. 
In general, surface runoff from active sludge application sites tended to have slightly elevated concentrations of some of the soluble constituents, such as nitrate, phosphorus, and the alkali and alkaline earth element ions such as calcium, and sometimes potassium, magnesium, and sodium, and often had higher conductivity. Concentrations of heavy metals such as cadmium, lead, and nickel were not necessarily elevated and were frequently below detection limits.

Separation of unfiltered sample into soluble and particulate fractions showed that elevated levels of most metals, including any regulated or heavy metals were usually not found in the soluble fraction (Table 8.5), where they might be of concern in terms of exposure to humans or animals, but in the particulate fraction (Tables 8.5 and 8.6), at least in terms of $\mathrm{mg} / \mathrm{L}$ contributed by the particulate fraction. Elevated concentrations were usually associated with samples with high suspended solids, that is, samples carrying a larger quantity of soil had higher total concentrations of heavy metals. This was true of both reference and treatment area samples, but, because of increased truck traffic and roads, for example, in the Pine Plantation, the treatment areas were more susceptible to erosion and tended to be higher in suspended solids (Tables 8.1 through 8.4, see especially 8.4). As an example, notice that iron and manganese tended to be high (above drinking water standards) in both treatment and reference runoff and somewhat higher in treatment samples (see total fractions in Tables 8.5 and 8.6), but the soluble fraction (Table 8.5) had negligible concentrations of either.

Concentrations of metals in the particulate fraction itself, in $\mathrm{mg} / \mathrm{kg}$, were not usually higher in treatment areas than in reference areas (Tables 8.5 and 8.6) and gave no indication that sludge particles were being transported off the application site, even though more soil particles may have been mobilized from application sites. 
Table 8.1. Surface water chemistry and nutrients at the Cottonwood site

\begin{tabular}{llcl}
\hline Mean & Range & $\begin{array}{c}\text { Number of } \\
\text { samples } \\
\text { analyzed }\end{array}$ & $\begin{array}{c}\text { Number of storms when } \\
\text { value was elevated/ } \\
\text { number of paired storms }\end{array}$ \\
\hline
\end{tabular}

\begin{tabular}{|c|c|c|c|c|}
\hline \multicolumn{5}{|c|}{ Site: reference creek } \\
\hline Fecal coliform & 0 & 1300 & 1 & \\
\hline Conductivity & 150 & $58-412$ & 8 & \\
\hline Alkalinity & 1.13 & $0.73-1.56$ & 8 & \\
\hline $\mathrm{pH}$ & 7.75 & $7.2-8.18$ & 8 & \\
\hline $\mathrm{NO}_{3}$ & 0.239 & $0.012-1.205$ & 8 & \\
\hline $\mathrm{NH}_{4}$ & 28.62 & $17-40.8$ & 8 & \\
\hline Total N & 0.589 & $0.312-0.920$ & 7 & \\
\hline Total P & 0.042 & $0.012-0.072$ & 7 & \\
\hline SRP & 0.010 & $0.007-0.017$ & 8 (3 ND) & \\
\hline TSS & 0.160 & $0.020-0.881$ & 8 & \\
\hline \multicolumn{5}{|c|}{ Site: Cottonwood Nonth Creek (treatment) } \\
\hline Fecal coliform & & 3200 & 1 & $1 / 1$ \\
\hline Conductivity & 88 & $30-160$ & 10 & $1 / 8$ \\
\hline Alkalinity & 0.692 & $0.19-1.36$ & 10 & $1 / 8$ \\
\hline $\mathrm{pH}$ & 6.98 & $6.5-8.2$ & 10 & $3 / 8$ \\
\hline $\mathrm{NO}_{3}$ & 0.236 & $0.005-1.000$ & 10 & $3 / 8$ \\
\hline $\mathrm{NH}_{4}$ & 190.2 & $4.0-1291$ & 10 & $3 \pi$ \\
\hline Total N & 0.800 & $0.34-2.78$ & 9 & $4 \pi$ \\
\hline Total P & 0.184 & $0.020-0.666$ & .9 & $4 / 8$ \\
\hline SRP & 0.163 & $0.005-0.48$ & $10(1 \mathrm{ND})$ & $3 / 8$ \\
\hline TSS & 0.075 & $0.035-0.121$ & 9 & \\
\hline
\end{tabular}

Site: Cottonwood South Creek

$\begin{array}{lcccc}\text { Fecal Coliform } & & & 0 & \\ \text { Conductivity } & 101 & 83-130 & 3 & 3 / 3 \\ \text { Alkalinity } & 0.78 & 0.61-0.96 & 3 & 0 / 3 \\ \mathrm{pH} & 7.97 & 7.84-8.07 & 3 & 3 / 3 \\ \mathrm{NO}_{3} & 1.04 & 0.892-1.243 & 3 & 2 / 3 \\ \mathrm{NH}_{4} & 2930 & 39-4518 & 3 & 3 / 3 \\ \text { Total } \mathrm{N} & 4.43 & 2.15-6.17 & 3 & 3 / 3 \\ \text { Total P } & 2.26 & 0.69-3.74 & 3 & 3 / 3 \\ \text { SRP } & 1.48 & 0.69-2.09 & 3 & 3 \\ \text { TSS } & 1.92 & 1.03-3.54 & 3 & \end{array}$

${ }^{a}$ Values are mean, range, and number of samples analyzed for each creek. The concentrations, conductivity, etc. for the two creeks in the treatment area were also compared pairwise for those dates (storm events) when both treatment and reference samples were available, and the number of those events when concentration (or other value) was elevated are given. Values were designated as elevated if they were greater than $110 \%$ of the reference value for that storm. The reference was taken from a stream flowing from the south side of Bear Creek Road, through a culvert and into the treatment area. The "Cottonwood South Creek" samples were taken from the same creek after it passed through a broad, gently sloping portion of the treatment area. This sampling position had water only during or after heavy rains. The "Cottonwood North Creek" samples were taken further downstream, after the creek passing through the treatment area had been joined by a creek passing through an untreated pine stand. This sampling position had water more frequently than the "South Creek" position. Some individual samples may have had inadequate volume to perform all analyses. Samples were collected during storm events from August 1989 through December 1990 . Units for fecal coliform are colonies $/ 100 \mathrm{~mL}$; for conductivity, $\mu \mathrm{mhos} / \mathrm{cm}$; for alkalinity, meg/L; for $\mathrm{NO}_{3}, \mathrm{mg} / \mathrm{L}$; for $\mathrm{NH}_{4}, \mu \mathrm{g} / \mathrm{L}$; for total $\mathrm{N}, \mathrm{mg} / \mathrm{L}$; for total $\mathrm{P}, \mathrm{mg} / \mathrm{L}$; for soluble reactive phosphorus (SRP), $\mathrm{mg} / \mathrm{L}$; and for total suspended solids (TSS), $\mathrm{mg} / \mathrm{L}$. Means are the mean of values above the detection limit. "ND" indicates the number of samples, if any, below the detection limit. 
Table 8.2. Surface water chemistry and nutrients at the Watson Road site ${ }^{a}$

\begin{tabular}{|c|c|c|c|c|}
\hline & Mean & Range & $\begin{array}{l}\text { Number of } \\
\text { samples } \\
\text { analyzed }\end{array}$ & $\begin{array}{c}\text { Sites with } \\
\text { consistently } \\
\text { higher values }\end{array}$ \\
\hline \multicolumn{5}{|c|}{ Site: Watson Road Reference Creek (WR) } \\
\hline Fecal coliform & 460 & & 1 & \\
\hline BOD & 3 & & 1 & \\
\hline Conductivity & 103 & $80-130$ & 3 & \\
\hline Alkalinity. & 0.91 & $0.38-1.60$ & 3 & \\
\hline $\mathrm{pH}$ & 7.41 & $6.88-7.95$ & 3 & \\
\hline $\mathrm{NO}_{3}$ & 0.01 & $0.008-0.014$ & 3 & \\
\hline $\mathrm{NH}_{4}$ & 26.55 & $14.3-38.8$ & 2 & \\
\hline Total N & 0.249 & $0.214-0.284$ & 2 & \\
\hline Total $\mathbf{P}$ & 0.045 & $0.044-0.046$ & 2 & \\
\hline SRP & 0.023 & $0.002-0.039$ & 3 & \\
\hline TSS & 0.016 & $0.010-0.025$ & 3 & \\
\hline \multicolumn{5}{|c|}{ Site: Watson Road treatment area (W1, W2, and W3) } \\
\hline Fecal coliform & 154 & $13-355$ & 3 & \\
\hline BOD & 3 & $2-4$ & 3 & \\
\hline Conductivity & 216 & $140-290$ & 9 & W2, W3 \\
\hline Alkalinity & 2.16 & $0.92-3.34$ & 9 & W2, W3 \\
\hline $\mathrm{pH}$ & 7.64 & $6.68-8.36$ & 9 & \\
\hline $\mathrm{NO}_{3}$ & 0.243 & $0.008-1.322$ & 9 & W1 \\
\hline $\mathrm{NH}_{4}$ & 28.42 & $15.0-45.0$ & 9 & \\
\hline Total N & 0.506 & $0.235-1.027$ & 6 & W1 \\
\hline Total P & 0.111 & $0.060-0.135$ & 6 & \\
\hline SRP & 0.069 & $0.020-0.127$ & 9 & W1 \\
\hline TSS & 0.316 & $0.021-1.178$ & 9 & W1 \\
\hline
\end{tabular}

Values are mean, range, and number of samples analyzed for each creek. Grab samples were collected from all three creeks during or after storm events on October 18, November 28, and December 17, 1990. The concentrations, conductivity, etc. for the three creeks in the treatment area were compared to the values from the reference creek. The reference was taken from a stream crossing Watson Road, east and upstream of the treatment area. The three treatment area samples were taken from creeks within the treatment area: W1 and W2 crossing Old County Road, and W3 crossing Watson Road inside the spray area. Some individual samples were not analyzed for total $\mathrm{N}$ or total $\mathrm{P}$. Units for fecal coliform are colonies $/ 100 \mathrm{~mL}$; for $\mathrm{BOD}, \mathrm{mg} / \mathrm{L}$; for conductivity, $\mu \mathrm{mhos} / \mathrm{cm}$; for alkalinity, meq/L; for $\mathrm{NO}_{3}, \mathrm{mg} / \mathrm{L}$; for $\mathrm{NH}_{3}, \mu \mathrm{g} / \mathrm{L}$; for total $\mathrm{N}, \mathrm{mg} / \mathrm{L}$; for total $\mathrm{P}$, mg/L; for soluble reactive phosphorus (SRP), mg/L; and for total suspended solids (TSS), mg/L. Means are the mean of values above the detection limit. "ND" indicates the number of samples, if any, below the detection limit.

${ }^{b}$ The sampling locations listed were consistently higher in concentration (or other parameter) than the other treatment sampling locations and contributed significantly to the higher means for that parameter. Where no location is listed in this column, values for the three locations were comparable. 
Table 8.3. Surface water chemistry and nutrients at the Rogers site ${ }^{a}$

\begin{tabular}{|c|c|c|c|c|}
\hline & Mean & Range & $\begin{array}{l}\text { Number of } \\
\text { samples } \\
\text { analyzed }\end{array}$ & $\begin{array}{l}\text { Number of storms when } \\
\text { value was elevated/ } \\
\text { number of paired storms }\end{array}$ \\
\hline \multicolumn{5}{|c|}{ Sample: reference grab sample (R4) } \\
\hline BOD & $<5$ & $<5$ & 2 & \\
\hline Fecal coliform & 245 & $100-390$ & 2 & \\
\hline Conductivity & 129 & $58-217$ & 12 & · \\
\hline Alkalinity & 2.17 & $0.50-10.04$ & 12 & . \\
\hline $\mathrm{pH}$ & 7.63 & $7.01-8.29$ & 12 & \\
\hline $\mathrm{NO}_{3}$ & 0.284 & $0.020-1.080$ & 12 & \\
\hline $\mathrm{NH}_{4}$ & 13.67 & $0-53.0$ & 12 & \\
\hline Total $\mathbf{N}$ & 0.763 & $0.023-1.331$ & 12 & \\
\hline Total $\mathbf{P}$ & 0.146 & $0.01-0.428$ & 12 & \\
\hline SRP & 0.055 & $0.010-0.139$ & 12 & \\
\hline TSS & 0.518 & $0.015-2.725$ & 13 & \\
\hline \multicolumn{5}{|c|}{ Sample: refenence compositor (RS) } \\
\hline $\mathrm{BOD}$ & 7 & & 1 & \\
\hline Fecal coliform & 70 & & 1 & \\
\hline Conductivity & 100 & $74-128$ & 3 & \\
\hline Alkalinity & 2.19 & $0.74-5.00$ & 3 & \\
\hline $\mathrm{pH}$ & 7.78 & $7.39-8.20$ & 3 & \\
\hline $\mathrm{NO}_{3}$ & 0.42 & $0.128-0.664$ & 3 & \\
\hline $\mathrm{NH}_{4}$ & 3.43 & $0-7.98$ & 3 & \\
\hline Total N & 1.463 & $0.672-2.402$ & 3 & \\
\hline Total P & 0.288 & $0.100-0.514$ & 3 & \\
\hline SRP & 0.071 & $0.038-0.094$ & 3 & \\
\hline TSS & 0.788 & $0.062-1.398$ & 3 & \\
\hline \multicolumn{5}{|c|}{ Sample: treament grab sample $(R I)$} \\
\hline BOD & $<7.75$ & $<5-10.5$ & 2 & $0 / 1$ \\
\hline Fecal coliform & $>475$ & $350->600$ & 2 & $0 / 1$ \\
\hline Conductivity & 212 & $74-429$ & 9 & $7 / 8$ \\
\hline Alkalinity & 0.96 & $0.61-1.30$ & 9 & $2 / 8$ \\
\hline $\mathrm{pH}$ & 7.46 & $7.07-8.36$ & 9 & \\
\hline $\mathrm{NO}_{3}$ & 8.879 & $0.337-23.13$ & 9 & $7 / 8$ \\
\hline $\mathrm{NH}_{4}$ & 54.12 & $9.60-207.8$ & 9 & $7 / 8$ \\
\hline Total $\mathbf{N}$ & 9.434 & $1.539-25.86$ & 9 & $8 / 8$ \\
\hline Total P & 1.955 & $0.210-5.520$ & 9 & $8 / 8$ \\
\hline SRP & 1.544 & $0.190-3.46$ & 9 & $8 / 8$ \\
\hline TSS & 0.213 & $0.013-0.538$ & 10 & $4 / 9$ \\
\hline \multicolumn{5}{|c|}{ Sample: treatment compositor $(R 2)$} \\
\hline BOD & $<5$ & & 1 & $0 / 1$ \\
\hline Fecal coliform & $>1200$ & & 1 & $1 / 1$ \\
\hline Conductivity & 194 & $102-323$ & 5 & $3 / 3$ \\
\hline Alkalinity & 0.84 & $0.46-1.26$ & 5 & $0 / 3$ \\
\hline $\mathrm{pH}$ & 7.42 & $7.27-7.87$ & 5 & \\
\hline $\mathrm{NO}_{3}$ & 5.259 & $1.427-8.711$ & 5 & $3 / 3$ \\
\hline $\mathrm{NH}_{4}$ & 316.67 & $70.65-688.0$ & 5 & $3 / 3$ \\
\hline Total N & 6.428 & $2.763-9.810$ & 5 & $2 / 3$ \\
\hline Total $\mathbf{P}$ & 0.761 & $0.167-1.640$ & 5 & $2 / 3$ \\
\hline SRP & 0.703 & $0.116-1.640$ & 5 & $3 / 3$ \\
\hline TSS & 0.065 & $0.006-0.192$ & 5 & $0 / 3$ \\
\hline
\end{tabular}




\begin{tabular}{|c|c|c|c|c|}
\hline & Mean & Range & $\begin{array}{l}\text { Number of } \\
\text { samples } \\
\text { analyzed }\end{array}$ & $\begin{array}{l}\text { Number of storms when } \\
\text { value was elevated/ } \\
\text { number of paired storms }\end{array}$ \\
\hline \multicolumn{5}{|c|}{ Sample: standing pool, grab sample (treatment) (R3) } \\
\hline BOD & 7 & & 1 & \\
\hline Fecal coliform & $>1200$ & & 1 & \\
\hline Conductivity & 424 & $85.3-1195$ & 4 & \\
\hline Alkalinity & 1.03 & $0.62-1.18$ & 4 & . \\
\hline $\mathrm{pH}$ & 7.41 & $7.24-7.54$ & 4 & \\
\hline $\mathrm{NO}_{3}$ & 27.11 & $1.436-96.15$ & 4 & \\
\hline $\mathrm{NH}_{4}$ & 724.43 & $16.63-2737$ & 4 & . \\
\hline Total N & 28.66 & $2.277-98.82$ & 4 & \\
\hline Total P & 2.43 & $1.22-4.14$ & 4 & \\
\hline SRP & 2.093 & $1.08-3.63$ & 4 & \\
\hline TSS & 0.194 & $0.075-0.47$ & 4 & \\
\hline
\end{tabular}

'Values are mean, range, and number of samples analyzed for each creek. The concentrations, conductivity, etc. for the compositor and grab samples in the treatment area were also compared pairwise to treatment samples of the same type for those dates when both were available, and the number of those events when concentration (or other value) was elevated are given. Values were designated as elevated if they were greater than $110 \%$ of the reference value for that storm. Samples contributing to this table were collected during or after rain events from July 1988 through May 1990, during and after the period of sludge application. Samples were take from compositors (R5 and R2 in reference and treatment areas, respectively, 7/14/88 through 3/30/89 only) and as grab samples near the location of the compositors (R4 and R1 in reference and treatment areas). In addition, as a "worst case", a grab sample was taken from a standing pool in the treatment area (R3, 7/14/88 through 2/17/89 only). Samples were not available from every sample position on each date, and that is reflected in the number of samples analyzed. Units for $\mathrm{BOD}$ are $\mathrm{mg} / \mathrm{L}$, fecal coliform are colonies $/ 100 \mathrm{~mL}$; for conductivity, $\mu \mathrm{mhos} / \mathrm{cm}$; for alkalinity, meq/L; for $\mathrm{NO}_{3}$, $\mathrm{mg} / \mathrm{L}$; for $\mathrm{NH}_{4}, \mu \mathrm{g} / \mathrm{L}$; for total $\mathrm{N}, \mathrm{mg} / \mathrm{L}$; for total $\mathrm{P}, \mathrm{mg} / \mathrm{L}$; for soluble reactive phosphorus (SRP), $\mathrm{mg} / \mathrm{L}$; and for total suspended solids (TSS), $\mathrm{mg} / \mathrm{L}$. Means are the mean of values above the detection limit. "ND" indicates the number of samples, if any, below the detection limit. 
Table 8.4(a). Water chemistry and nutrients in surface runoff at the Pine Plantation Site (means for four sample locations and types)

\begin{tabular}{|c|c|c|c|c|c|c|c|c|c|c|c|}
\hline & Conduct & pH & Alk. & $\mathrm{NO}_{3}$ & $\mathrm{NH}_{4}$ & TN & TP & SRP, & TSS & BOD & Fecal Coliform \\
\hline \multicolumn{12}{|c|}{ Refarence, Grab } \\
\hline Mean P3 & 43.7 & 5.93 & 0.60 & 0.130 & 35.19 & 0.464 & 0.040 & 0.016 & 0.045 & 7.8 & 2350 \\
\hline Std & 12.3 & 0.27 & 0.96 & 0.162 & 30.86 & 0.211 & 0.032 & 0.022 & 0.054 & & \\
\hline $\mathbf{n}$ & 7 & 7 & 7 & 7 & 7 & 7 & 7 & 7 & 7 & 1 & 1 \\
\hline \multicolumn{12}{|c|}{ Reference, Compasitor } \\
\hline Mean P4 & 159.0 & 6.98 & 0.66 & 0.382 & 226.66 & 1.001 & 0.079 & 0.042 & 0.045 & & \\
\hline Std & 184.4 & 0.73 & 0.84 & 0.231 & 226.25 & 0.429 & 0.026 & 0.015 & 0.030 & & \\
\hline $\mathrm{n}$ & 4 & 4 & 4 & 4 & 4 & 4 & 4 & 4 & 4 & & \\
\hline \multicolumn{12}{|c|}{ Theatmens, Grab } \\
\hline Mean P1 & 119 & 6.68 & 0.54 & 6.657 & 831.36 & 8.181 & 1.466 & 0.785 & 1.24 & 8.4 & 6520 \\
\hline Std & 51 & 0.80 & 0.59 & 4.679 & 1290.7 & 5.250 & 1.958 & 1.363 & 2.16 & 8.4 & 5980 \\
\hline $\mathrm{n}$ & 16 & 16 & 16 & 16 & 16 & 16 & 16 & 16 & 16 & 2 & 2 \\
\hline \multicolumn{12}{|c|}{ Treatment, Compasitor } \\
\hline Mean P2 & 257 & 7.76 & 1.34 & 4.612 & 897.7 & 6.186 & 0.539 & 0.373 & 0.616 & . & \\
\hline Std & 46 & 0.22 & 0.34 & 3.734 & 1249.9 & 6.024 & 0.649 & 0.427 & 0.999 & 4 & 4 \\
\hline $\mathbf{n}$ & 4 & 4 & 4 & 4 & 4 & 4 & 4 & 4 & 4 & 4 & 4 \\
\hline
\end{tabular}

NOTES: Chemical parameters and units were: Conductivity, $\mu$ mhos $/ \mathrm{cm} ; \mathrm{pH}$; alkalinity, meq/L; $\mathrm{NO}_{3}, \mathrm{mg} / \mathrm{L} ; \mathrm{NH}_{4}, \mu \mathrm{g} / \mathrm{L} ; \mathrm{Total} \mathrm{P}$, mg/L; soluble reactive phosphorus (SRP), mg/L; biological oxygen demand (BOD) $\mathrm{mg} / \mathrm{L}$; fecal coliform, colonies/100mL; for total $\mathrm{N}, \mathrm{mg} / \mathrm{L}$; and total suspended solids (TSS), $\mathrm{mg} / \mathrm{L}$. Mean, standard deviation, and sample number for four sample locations and types: compositor samples from reference (ref) and sludge treatment (trt) plots, sampled from November 1988 through March 1989, and grab samples from the same locations, sampled from July 1988 through February 1990. Samples IDs are as follows: P4, a compositor in the reference plot; P3, a grab sample from near the P4 compositor on the reference site; P2, a compositor in the treatment plot; P1, a grab sample from near the P2 compositor on the treatment site. 
Table 8.4(b). Runoff collections on two typical dates; grab samples

\begin{tabular}{|c|c|c|c|c|c|c|c|c|c|c|c|c|c|c|}
\hline Date & Sample & TRT & Type & Cond. & pH & Alk. & $\begin{array}{l}\mathrm{NO}_{3} \\
\mathrm{mg} / \mathrm{L}\end{array}$ & $\begin{array}{l}\mathrm{NH}_{4} . \\
\mu \mathrm{g} / \mathrm{L}\end{array}$ & $\begin{array}{c}\mathrm{TN} \\
\mathrm{mg} / \mathrm{L}\end{array}$ & $\underset{\mathrm{mg} / \mathrm{L}}{\mathbf{T P}}$ & $\begin{array}{l}\text { SRP, } \\
\mathrm{mg} / \mathrm{L}\end{array}$ & $\begin{array}{l}\text { TSS, } \\
\text { mg/L }\end{array}$ & BOD & $\begin{array}{l}\text { Pecal } \\
\text { coliform }\end{array}$ \\
\hline $05 / 05 / 89$ & P3 & Ref & Grab & 48 & 6.14 & 2.52 & 0.112 & 89.3 & 0.859 & 0.092 & 0.045 & 0.150 & 7.8 & 2350 \\
\hline $05 / 05 / 89$ & $1132 S P$ & Trt & Grab & 249 & 7.59 & 2.08 & 4.214 & 7402.2 & 17.502 & 3.860 & 2.475 & 0.623 & 46.1 & 47000 \\
\hline $05 / 05 / 89$ & PI & Trt, dil. & Grab & 134 & 7.70 & 2.32 & 3.799 & 2576.3 & 12.786 & 5.200 & 1.110 & 4.8301 & 16.8 & 12500 \\
\hline $05 / 05 / 89$ & PI rep & Trt & Grab & 1.36 & 7.72 & 2.28 & 3.613 & 2800.4 & 12.982 & 4.500 & 1.040 & 5.522 & & \\
\hline $05 / 05 / 89$ & $\mathrm{C}$ at $\mathrm{C}$ & Trt, dil. & Grab & 180 & 7.76 & 2.40 & 2.064 & 849.3 & 5.437 & 0.800 & 0.210 & 2.287 & & \\
\hline $05 / 05 / 89$ & P6 & Trt, dil. & Grab & 92 & 8.14 & 3.50 & 0.137 & 41.7 & 1.295 & 0.244 & 0.050 & 1.524 & & \\
\hline 06/09/89 & P3 & Ref & Grab & 55 & 6.12 & 0.22 & 0.484 & 60.3 & 0.436 & 0.038 & 0.050 & 0.060 & & \\
\hline $06 / 09 / 89$ & $1132 S P$ & Trt & Grab & 426 & 6.30 & 0.00 & 38.295 & 5104.2 & 47.100 & 6.760 & 6.260 & 0.142 & & \\
\hline $06 / 09 / 89$ & PI & Trt & Grab & 237 & 7.21 & 0.50 & 16.585 & 2547.6 & 22.185 & 6.460 & 5.500 & 3.203 & & \\
\hline $06 / 09 / 89$ & PI rep & $\operatorname{Trt}$ & Grab & 237 & 7.18 & 0.52 & 16.625 & 2517.4 & 22.110 & 6.620 & & 2.590 & & \\
\hline $06 / 09 / 89$ & $\mathrm{C}$ at $\mathrm{C}$ & Trt, dil. & Grab & 230 & 7.02 & 0.60 & 14,612 & 1690.5 & 18.700 & 2.600 & 2.300 & 0.247 & & \\
\hline $06 / 09 / 89$ & P6 & Trt, dil. & Grab & 124 & 7.66 & 0.82 & 3.664 & 261.1 & 4.812 & 0.640 & 0.370 & 0.232 & & \\
\hline
\end{tabular}


Table 8.4(c). Runoff collections on two typical dates; compositors plus grab samples

\begin{tabular}{|c|c|c|c|c|c|c|c|c|c|c|c|c|}
\hline Date & Sample & TRT & Type & Conduct. & pH & Alk. & $\begin{array}{l}\mathrm{NO}_{3} \\
\mathrm{mg} / \mathrm{L}\end{array}$ & $\begin{array}{l}\mathrm{NH}_{4} \\
\mu \mathrm{g} / \mathrm{L}\end{array}$ & $\begin{array}{c}\mathrm{TN} \\
\mathrm{mg} / \mathrm{L}\end{array}$ & $\begin{array}{c}\text { TP } \\
\mathrm{mg} / \mathrm{L}\end{array}$ & $\begin{array}{l}\text { SRP, } \\
\text { mg/L }\end{array}$ & $\begin{array}{c}\text { TSS, } \\
\text { mg/L. }\end{array}$ \\
\hline $11 / 19 / 88$ & P4 & Ref & Comp & 478 & 8.22 & 2.12 & 0.572 & 0.00 & 0.750 & 0.080 & & 0.093 \\
\hline $11 / 19 / 88$ & P5,pool & Ref & Grab & 64 & 5.86 & 0.72 & 0.230 & 225.76 & 1.248 & 0.096 & 0.050 & 0.018 \\
\hline $11 / 19 / 88$ & P2 & Trt & Comp & 331 & 7.74 & 1.04 & 2.772 & 495.08 & 3.207 & 0.196 & 0.165 & 0.086 \\
\hline $11 / 19 / 88$ & P6 & Trt, dil & Grab & 225 & 6.96 & 2.50 & 0.607 & 0.00 & 0.756 & 0.017 & 0.001 & 0.004 \\
\hline $01 / 12 / 89$ & $\mathbf{P 3}$ & Ref & Grab & 49.5 & 5.73 & 0.06 & 0.049 & 0.00 & 0.333 & 0.014 & 0.001 & 0.005 \\
\hline $01 / 12 / 89$ & P4 & Ref & Comp & 57 & 6.74 & 0.22 & 0.031 & 2.85 & 0.432 & 0.119 & 0.063 & 0.014 \\
\hline $01 / 12 / 89$ & P5,pool & Ref & Grab & 29 & 6.49 & 0.10 & 0.116 & 0.00 & 0.778 & 0.067 & 0.016 & 0.013 \\
\hline $01 / 12 / 89$ & P1 & Trt & Grab & 97 & 7.09 & 0.46 & 2.805 & 513.00 & 5.519 & 1.160 & 0.860 & 0.532 \\
\hline $01 / 12 / 89$ & P2 & Trt & Comp & 251 & 8.10 & 1.92 & 1.457 & 11.86 & 1.653 & 0.101 & 0.079 & 0.007 \\
\hline $01 / 12 / 89$ & P6 & Trt, dil & Grab & 104 & 7.23 & 0.56 & 2.576 & 204.03 & 3.265 & 0.251 & 0.173 & 0.058 \\
\hline $01 / 12 / 89$ & P6 rep & 'Trt, dil & Grab & 107 & 7.31 & 1.18 & 2.628 & 209.68 & 3.216 & 0.267 & 0.176 & 0.066 \\
\hline
\end{tabular}


Table 8.5. Metals in grab samples of surface runoff at the McCoy Site for two dates after sludge application.

Data listed by date and as total, soluble, or particulate fraction where data available. BMDL and < indicate values below the analytical detection limits (ICP).

\begin{tabular}{|c|c|c|c|c|c|c|c|}
\hline & Date & $\mathrm{Ag}$ & Al & As & B & $\mathrm{Ba}$ & $\mathrm{Be}$ \\
\hline \multicolumn{8}{|l|}{ Total, mg/L } \\
\hline UPSTREAM (C) & $02 / 27 / 87$ & $<.0084$ & 0.780 & $<.017$ & $<.013$ & 0.069 & $<.00033$ \\
\hline DOWNSTREAM (D) & $02 / 27 / 87$ & $<.0077$ & 3.00 & $<.015$ & $<.012$ & 0.067 & $<.00031$ \\
\hline Soluble,mg/L & . & & & & & & \\
\hline UPSTREAM (C) & $02 / 27 / 87$ & $<.05$ & $<.2$ & $<.01$ & $<.08$ & 0.040 & $<.002$ \\
\hline DOWNSTREAM (D) & $02 / 27 / 87$ & $<.05$ & $<.2$ & $<.01$ & $<.08$ & $<.053$ & $<. t X) 2$ \\
\hline \multicolumn{8}{|l|}{ Total, mg/L } \\
\hline UPSTREAM (C) & $01 / 19 / 88$ & 0.010 & 0.620 & 0.045 & $<.08$ & 0.030 & $<.0003$ \\
\hline DOWNSTREAM (D) & $01 / 19 / 88$ & 0.009 & 4.700 & 0.039 & $<.08$ & 0.051 & $<.0003$ \\
\hline \multicolumn{8}{|l|}{ Particulate, mg/L } \\
\hline UPSTREAM (C) & $01 / 19 / 88$ & 0.001 & 0.124 & 0.006 & 0.016 & 0.022 & 0.000 \\
\hline DOWNSTREAM (D) & $01 / 19 / 88$ & 0.002 & $0.850^{\prime}$ & 0.016 & 0.040 & 0.130 & 0.000 \\
\hline \multicolumn{8}{|l|}{ Particulate, mg/L } \\
\hline UPSTREAM (C) & $01 / 19 / 88$ & 0.036 & 5.636 & 0.273 & 0.727 & 1.000 & 0.003 \\
\hline DOWNSTREAM (D) & $01 / 19 / 88$ & 0.020 & $\& 500$ & 0.160 & $0.4 \mathrm{~W}$ & 1.300 & $0.0 u$ \\
\hline
\end{tabular}


Table 8.5 (continued)

\begin{tabular}{|c|c|c|c|c|c|c|c|}
\hline & Date & $\mathrm{Ca}$ & $\mathrm{Cd}$ & Co & $\mathrm{Cr}$ & $\mathrm{Cu}$ & $\mathrm{Fe}$ \\
\hline \multicolumn{8}{|l|}{ Total, mg/L } \\
\hline UPSTREAM (C) & $02 / 27 / 87$ & 17.00 & BMDL & $<.0017$ & $<.0067$ & $<.0033$ & 0.86 \\
\hline DOWNSTREAM (D) & $02 / 27 / 87$ & 20.00 & BMDL & 0.003 & 0.007 & 0.005 & 3.300 \\
\hline \multicolumn{8}{|l|}{ Soluble,mg/L } \\
\hline UPSTREAM (C) & $02 / 27 / 87$ & 18.00 & $<.005$ & $<.01$ & $<.04$ & $<.02$ & $<.0-3$ \\
\hline DOWNSTREAM (D) & $02 / 27 / 87$ & 25.00 & $<.005$ & $<.01$ & $<.04$ & $<.02$ & 0.089 \\
\hline Total, mg/L & . & & & & & & \\
\hline UPST'REAM (C) & $01 / 19 / 88$ & 29.000 & 0.002 & $<.003$ & 0.011 & $<.010$ & 0.410 \\
\hline DOWNSTREAM (D) & $01 / 19 / 88$ & 38.000 & 0.002 & $<.003$ & 0.013 & $<.010$ & 3.400 \\
\hline \multicolumn{8}{|l|}{ Particulate, $\mathrm{mg} / \mathrm{L}$} \\
\hline UPSTREAM (C) & $01 / 19 / 88$ & 0.220 & 0.000 & 0.001 & 0.001 & 0.001 & 0.200 \\
\hline DOWNSTREAM (D) & $01 / 19 / 88$ & 0.700 & 0.001 & 0.010 & 0.001 & 0.625 & 0.500 \\
\hline \multicolumn{8}{|l|}{ Particulate, $\mathrm{mg} / \mathrm{L}$} \\
\hline UPSTREAM (C) & $01 / 19 / 88$ & 10.000 & 0.020 & 0.027 . & 0.327 & 0.055 & 9.091 \\
\hline DOWNSTREAM (D) & $01 / 19 / 88$ & 7.000 & 0.010 & 0.095 & 0.009 & 6.250 & 5.000 \\
\hline
\end{tabular}


Table 8.5 (continued)

\begin{tabular}{|c|c|c|c|c|c|c|c|}
\hline & Date & $\mathrm{Ga}$ & $\mathbf{K}$ & $\mathbf{L i}$ & $\mathrm{Mg}$ & $\mathrm{Mn}$ & MO \\
\hline \multicolumn{8}{|l|}{ Total, mg/L } \\
\hline UPSTREAM (C) & $02 / 27 / 87$ & $<.05$ & & $<.033$ & 5.20 & 0.060 & $<.0067$ \\
\hline DOWNSTREAM (D) & $02 / 27 / 87$ & $<.046$ & & $<.031$ & 4.80 & 0.120 & $<.0062$ \\
\hline \multicolumn{8}{|l|}{ Soluble,mg/L } \\
\hline UPSTREAM (C) & $02 / 27 / 87$ & $<.03$ & & $<.02$ & 5.60 & $<.005$ & $<.04$ \\
\hline DOWNSTREAM (D) & $02 / 27 / 87$ & $<.03$ & & $<.02$ & 5.30 & $<.005$ & $<.04$ \\
\hline \multicolumn{8}{|l|}{ Total, mg/L } \\
\hline UPSTREAM (C) & $01 / 19 / 88$ & $<.3$ & 1.300 & $<.2$ & 12.000 & 0.026 & $<.04$ \\
\hline DOWNSTREAM (D) & $01 / 19 / 88$ & $<.3$ & 3.000 & $<.2$ & 11.000 & 0.065 & $<.04$ \\
\hline \multicolumn{8}{|l|}{ Particulate, $\mathrm{mg} / \mathrm{L}$} \\
\hline UPSTREAM (C) & $01 / 19 / 88$ & 0.060 & 0.008 & 0.040 & 0.076 & 0.017 & 0.008 \\
\hline DOWNSTREAM (D) & $01 / 19 / 88$ & 0.150 & 0.035 & 0.100 & 0.100 & 0.022 & 0.020 \\
\hline \multicolumn{8}{|l|}{ Particulate, $\mathrm{mg} / \mathrm{g}$} \\
\hline UPSTREAM (C) & $01 / 19 / 88$ & 2.727 & 0.364 & 1.818 & 3.455 & 0.755 & 0.364 \\
\hline DOWNSTREAM (D) & $01 / 19 / 88$ & 1.500 & 0.350 & 1.000 & 1.000 & 0.220 & 0.200 \\
\hline
\end{tabular}


Table 8.5 (continued)

\begin{tabular}{|c|c|c|c|c|c|c|c|}
\hline & Date & $\mathrm{Na}$ & $\mathrm{Ni}$ & $\mathbf{p}$ & $\mathrm{Pb}$ & $\mathrm{Sb}$ & $\mathrm{Se}$ \\
\hline \multicolumn{8}{|l|}{ Total, mg/L } \\
\hline UPSTREAM (C) & $02 / 27 / 87$ & 3.50 & $<0.01$ & $<0.05$ & $<.033$ & $<.033$ & $<.033$ \\
\hline DOWNSTREAM(D) & $02 / 27 / 87$ & 2.30 & $<0.0092$ & 0.120 & $<.031$ & $<.031$ & $<.031$ \\
\hline \multicolumn{8}{|l|}{ Soluble, mg/L } \\
\hline UPSTREAM (C) & $02 / 27 / 87$ & 4.30 & $<.06$ & 0.300 & $<.2$ & $<.2$ & $<.2$ \\
\hline DOWNSTREAM (D) & $02 / 27 / 87$ & 4.30 & $<.06$ & 0.300 & $<.2$ & $<.2$ & $<.2$ \\
\hline Total, mg/L & & & & & & - & \\
\hline UPSTREAM (C) & $01 / 19 / 88$ & 11.000 & $<.006$ & $<0.3$ & $<.03$ & $<.03$ & $<.04$ \\
\hline DOWNSTREAM (D) & $01 / 19 / 88$ & 7.900 & $<0.006$ & $<0.3$ & $<.03$ & $<.03$ & $<.04$ \\
\hline \multicolumn{8}{|l|}{ Particulate, $\mathrm{mg} / \mathrm{L}$} \\
\hline UPSTREAM (C) & $01 / 19 / 88$ & 0.004 & 0.002 & 0.060 & 0.006 & 0.006 & 0.008 \\
\hline DOWNSTREAM (D) & $01 / 19 / 88$ & 0.105 & 0.004 & 0.185 & 0.028 & 0.015 & 0.020 \\
\hline \multicolumn{8}{|l|}{ Particulate, mg/L } \\
\hline UPSTREAM (C) & $01 / 19 / 88$ & 0.182 & 0.083 & 2.727 & 0.273 & 0.273 & 0.364 \\
\hline DOWNSTREAM (D) & $01 / 19 / 88$ & 1.050 & 0.035 & 1.850 & 0.275 & 0.150 & 0.200 \\
\hline
\end{tabular}


Table 8.5 (continued)

\begin{tabular}{|c|c|c|c|c|c|c|c|c|}
\hline & Date & $\mathrm{Si}$ & Sn & $\mathrm{Sr}$ & Ti & $\mathrm{V}$ & $\overline{Z n}$ & $\mathrm{Zr}$ \\
\hline \multicolumn{9}{|l|}{ Total, mg/L } \\
\hline UPSTREAM (C) & $02 / 27 / 87$ & 2.50 & $<.0084$ & 0.037 & 0.013 & 0.004 & 0.010 & $<.0033$ \\
\hline DOWNSTREAM (D) & $02 / 27 / 87$ & 2.40 & $<.0077$ & 0.034 & 0.017 & 0.007 & 0.018 & 0.004 \\
\hline \multicolumn{9}{|l|}{ Soluble, mg/L } \\
\hline UPSTREAM (C) & $02 / 27 / 87$ & 2.50 & $<.05$ & 0.044 & $<.02$ & $<.01$ & $<.02$ & $<.02$ \\
\hline DOWNSTREAM (D) & $02 / 27 / 87$ & 2.40 & $<.05$ & 0.045 & $<.02$ & $<.01$ & $<.02$ & $<.02$ \\
\hline \multicolumn{9}{|l|}{ Total, mg/L } \\
\hline UPSTREAM (C) & $01 / 19 / 88$ & 3.800 & $<.05$ & 0.047 & 0.040 & 0.007 & 0.004 & $<.02$ \\
\hline DOWNSTREAM (D) & $01 / 19 / 88$ & 11.000 & $<.05$ & 0.060 & 0.090 & 0.010 & 0.013 & $<.02$ \\
\hline \multicolumn{9}{|l|}{ Particulate, mg/L } \\
\hline UPSTREAM (C) & $01 / 19 / 88$ & 0.182 & 0.010 & 0.001 & 0.068 & 0.001 & 0.010 & 0.004 \\
\hline DOWNSTREAM (D) & $01 / 19 / 88$ & 0.155 & 0.025 & 0.003 & 0.075 & 0.002 & 0.015 & 0.010 \\
\hline \multicolumn{9}{|l|}{ Particulate, mg/L } \\
\hline UPMREAM (C) & $01 / 19 / 88$ & 8.273 & 0.455 & 0.045 & 3.091 & 0.036 & 0.445 & 0.182 \\
\hline DOWNSTREAM (D) & $01 / 19 / 88$ & 1.550 & 0.250 & 0.025 & 0.750 & 0.020 & 0.150 & 0.100 \\
\hline
\end{tabular}


Table 8.6(a). Metal concentrations in surface runoff at the Rogers site, for two sample both the sludge treatment field and a reference field nearby. All samples were taken during the active sludge application period. Analysis by ICP. Concentrations in total fraction are in $\mathrm{mg} / \mathrm{L}$ and in particulate fraction, $\mathrm{mg} / \mathrm{g}$.

\begin{tabular}{|c|c|c|c|c|c|c|c|c|c|}
\hline & Date & $\mathrm{Ag}$ & $\mathrm{Al}$ & As & B & $\mathrm{Ba}$ & $\mathrm{Be}$ & $\mathrm{Ca}$ & Cd \\
\hline \multicolumn{10}{|c|}{ Total (mg/L) } \\
\hline Reference & $09 / 12 / 87$ & $<.050$ & 2.60 & $<.10$ & $<.08$ & $<.020$ & $<.002$ & $>10$ & $<.005$ \\
\hline Treatment & $09 / 12 / 87$ & $<.050$ & 17.00 & $<.10$ & $<.08$ & 0.14 & $<.002$ & $>10$ & $<.005$ \\
\hline \multicolumn{10}{|c|}{ Particulate (mg/g) } \\
\hline Reference & $09 / 12 / 87$ & 0.161 & 15.16 & 0.323 & 0.258 & 0.065 & 0.006 & 27.10 & 0.016 \\
\hline Treatment & $09 / 12 / 87$ & 0.027 & 10.22 & 0.054 & 0.043 & 0.065 & 0.001 & 5.914 & 0.003 \\
\hline \multicolumn{10}{|c|}{ Total (mg/L) } \\
\hline Reference & $01 / 19 / 88$ & 0.011 & 10.000 & $<.03$ & $<.08$ & 0.054 & 0.0005 & 27.00 & 0.002 \\
\hline Treatment & $01 / 19 / 88$ & 0.013 & 3.300 & 0.034 & $<.08$ & 0.040 & $<.0003$ & 76.00 & $<.002$ \\
\hline \multicolumn{10}{|c|}{ Particulate (mg/g) } \\
\hline Reference & $01 / 19 / 88$ & 0.010 & 11.951 & 0.095 & 0.195 & 0.124 & 0.001 & 15.12 & 0.006 \\
\hline Treatment & $01 / 19 / 88$ & 0.011 & 8.857 & .0 .094 & 0.229 & 0.109 & 0.001 & 14.286 & 0.006 \\
\hline
\end{tabular}


Table 8.6(a) (continued)

\begin{tabular}{|c|c|c|c|c|c|c|c|c|c|}
\hline & Date & Co & $\mathrm{Cr}$ & $\mathrm{Cu}$ & $\mathrm{Fe}$ & $\mathrm{Ga}$ & $\mathrm{K}$ & $\mathrm{Li}$ & $\mathrm{Mg}$ \\
\hline \multicolumn{10}{|c|}{ Total $(\mathrm{mg} / \mathrm{L})$} \\
\hline Reference & $09 / 12 / 87$ & $<.010$ & 0.190 & $<.020$ & 5.20 & $<.30$ & 15.00 & $<.20$ & 3.50 \\
\hline Treatment & $09 / 12 / 87$ & 0.017 & $<.040$ & 0.059 & 18.00 & $<.30$ & 19.00 & $<.20$ & 12.00 \\
\hline \multicolumn{10}{|c|}{ Particulate (mg/g) } \\
\hline Reference & $09 / 12 / 87$ & 0.003 & 0.129 & 0.065 & 24.52 & 0.968 & 0.297 & 0.065 & 2.74 \\
\hline Treatment & $09 / 12 / 87$ & 0.005 & 0.024 & 0.017 & 16.67 & 0.204 & 0.204 & 0.108 & 1.56 \\
\hline \multicolumn{10}{|c|}{ Total (mg/L) } \\
\hline Reference & $01 / 19 / 88$ & $<.003$ & 0.021 & 0.013 & 13.00 & $<.3$ & 5.70 & $<.2$ & 4.60 \\
\hline Treatment & $01 / 19 / 88$ & $<.003$ & 0.016 & 0.034 & 3.60 & $<.3$ & 9.70 & $<.2$ & 11.00 \\
\hline \multicolumn{10}{|c|}{ Particulate (mg/g) } \\
\hline Reference & $01 / 19 / 88$ & 0.007 & 0.112 & 0.439 & 19.02 & 0.732 & 0.415 & 0.488 & 2.44 \\
\hline Treatment & $01 / 19 / 88$ & 0.009 & 0.126 & 0.109 & 11.71 & 0.857 & 0.629 & 0.571 & 2.029 \\
\hline
\end{tabular}


Table 8.6(a) (continued)

\begin{tabular}{|c|c|c|c|c|c|c|c|c|c|}
\hline & Date & $\mathrm{Mn}$ & Mo & $\mathrm{Na}$ & $\mathbf{N i}$ & $\mathbf{P}$ & $\mathrm{Pb}$ & $\mathrm{Sb}$ & $\mathrm{Se}$ \\
\hline \multicolumn{10}{|c|}{ Total $(\mathrm{mg} / \mathrm{L})$} \\
\hline Reference & $09 / 12 / 87$ & 0.120 & $<.040$ & 0.810 & $<.060$ & 0.47 & $<.20$ & $<.20$ & $<.20$ \\
\hline Treatment & $09 / 12 / 87$ & 1.500 & $<.040$ & 4.60 & $<.06$ & 5.00 & $<.20$ & $<.20$ & $<.20$ \\
\hline \multicolumn{10}{|c|}{ Particulate (mg/g) } \\
\hline Reference & $09 / 12 / 87$ & 0.310 & 0.013 & 1.74 & 0.019 & 0.97 & 0.065 & 0.065 & 0.065 \\
\hline Treatment & $09 / 12 / 87$ & 0.753 & 0.022 & 0.269 & 0.032 & 1.34 & 0.108 & 0.108 & 0.108 \\
\hline \multicolumn{10}{|c|}{ Total $(\mathrm{mg} / \mathrm{L})$} \\
\hline Reference & $01 / 19 / 88$ & 0.17 & $<.04$ & $<.2$ & 0.008 & 0.53 & $<.03$ & $<.03$ & $<.04$ \\
\hline Treatment & $01 / 19 / 88$ & 0.21 & $<.04$ & 4.40 & 0.007 & 3.30 & $<.03$ & $<.03$ & $<.04$ \\
\hline \multicolumn{10}{|c|}{ Particulate (mg/g) } \\
\hline Reference & $01 / 19 / 88$ & 0.463 & 0.098 & 0.488 & 0.059 & 0.73 & 0.159 & 0.073 & 0.098 \\
\hline Treatment & $01 / 19 / 88$ & 0.743 & 0.114 & 0.571 & 0.063 & 3.43 & 0.114 & 0.086 & 0.114 \\
\hline
\end{tabular}


Table 8.6(a) (continued)

\begin{tabular}{|c|c|c|c|c|c|c|c|c|}
\hline & Date & Si & Sn & $\mathbf{S r}$ & $\mathrm{Ti}$ & V & $\mathrm{Zn}$ & $\mathrm{Zr}$ \\
\hline \multicolumn{9}{|c|}{ Total (mg/L) } \\
\hline Reference & $09 / 12 / 87$ & 5.90 & $<.050$ & 0.070 & $<.020$ & $<.020$ & $<.020$ & $<.020$ \\
\hline Treatment & $09 / 12 / 87$ & 19.00 & $<.050$ & 0.081 & 0.073 & 0.037 & 0.340 & $<.020$ \\
\hline \multicolumn{9}{|c|}{ Particulate (mg/g) } \\
\hline Reference & $09 / 12 / 87$ & 15.81 & 0.161 & 0.039 & 1.35 & 0.065 & 0.677 & 0.065 \\
\hline Treatment & $09 / 12 / 87$ & 3.33 & 0.027 & 0.011 & 0.274 & 0.017 & 0.226 & 0.011 \\
\hline \multicolumn{9}{|c|}{ Total (mg/L) } \\
\hline Reference & $01 / 19 / 88$ & 20.00 & $<.05$ & 0.039 & 0.20 & 0.018 & 0.029 & 0.020 \\
\hline Treatment & $01 / 19 / 88$ & 8.20 & $<.05$ & 0.071 & 0.023 & 0.009 & 0.081 & $<0.02$ \\
\hline \multicolumn{9}{|c|}{ Particulate (mg/g) } \\
\hline Reference & $01 / 19 / 88$ & 15.366 & 0.122 & 0.029 & 1.024 & 0.021 & 0.244 & 0.054 \\
\hline Treatment & $01 / 19 / 88$ & 8.286 & 0.143 & 0.028 & 1.429 & 0.011 & 0.457 & 0.057 \\
\hline
\end{tabular}


Table 8.6(b). Metal concentrations in grab samples of surface runoff at the Rogers site, on 2/27/87, taken from both the sludge treatment field (including a standing pool), and a reference field nearby. Analysis was of total sample, by ICP. Concentrations are in $\mathrm{mg} / \mathrm{L}$.

\begin{tabular}{|c|c|c|c|c|c|c|c|c|}
\hline & Ag & Al & As & B & $\mathrm{Ba}$ & $\mathrm{Be}$ & $\mathrm{Ca}$ & $\mathrm{Cd}$ \\
\hline Reference & & 10.50 & & & & 0.0003 & 15.00 & \\
\hline Treatment & $<0.0077$ & 3.70 & $<0.015$ & 0.014 & 0.054 & $<0.0003$ & 25.00 & $<0.0008$ \\
\hline \multirow[t]{2}{*}{ Standing Pool } & & 8.50 & & & 0.088 & 0.005 & 20.00 & 0.009 \\
\hline & $\mathrm{Co}$ & $\mathrm{Cr}$ & $\mathrm{Cu}$ & $\mathrm{Fe}$ & $\mathrm{Ga}$ & $\mathrm{K}$ & $\mathbf{L i}$ & $\mathrm{Mg}$ \\
\hline Reference & 0.004 & 0.012 & 0.005 & 10.30 & & & & 3.00 \\
\hline Treatment & 0.002 & 0.008 & 0.007 & 4.00 & $<0.046$ & & $<0.031$ & 3.20 \\
\hline \multirow[t]{2}{*}{ Standing Pool } & 0.005 & 0.017 & 0.017 & 10.00 & & & & 4.90 \\
\hline & $\mathrm{Mn}$ & Mo & $\mathrm{Na}$ & $\mathrm{Ni}$ & $\mathbf{P}$ & $\mathrm{Pb}$ & $\mathrm{Sb}$ & Se \\
\hline Reference & 0.093 & & 0.39 & & 0.27 & & & \\
\hline Treatment & 0.034 & $<0.0062$ & 0.99 & $\begin{array}{l}<0.009 \\
2\end{array}$ & 1.30 & $<0.031$ & $<0.031$ & $<0.031$ \\
\hline \multirow[t]{2}{*}{ Standing Pool } & 0.17 & & 1.60 & 0.010 & 3.00 & & & \\
\hline & $\mathrm{Si}$ & Sn & $\mathrm{Sr}$ & $\mathrm{Ti}$ & $\mathbf{V}$ & $\mathrm{Zn}$ & $\mathrm{Zr}$ & \\
\hline Reference & 3.80 & & 0.023 & 0.026 & 0.015 & 0.076 & 0.006 & \\
\hline Treatment & 2.80 & $<0.0077$ & 0.026 & 0.018 & 0.007 & 0.029 & 0.004 & \\
\hline Standing Pool & 2.90 & & 0.026 & 0.025 & 0.014 & 0.071 & 0.006 & \\
\hline
\end{tabular}


Table 8.7(a). Metals in surface runoff at the Pine Plantation Site. (Ag through $\mathrm{Cr}$ )

\begin{tabular}{lllllllllllll}
\hline Site & TRT & Date & $\mathrm{Ag}$ & $\mathrm{Al}$ & $\mathrm{As}$ & $\mathrm{B}$ & $\mathrm{Ba}$ & $\mathrm{Be}$ & $\mathrm{Ca}$ & $\mathrm{Cd}$ & $\mathrm{Co}$ & $\mathrm{Cr}$ \\
\hline P1' & Trt grab & $07 / 14 / 88$ & $<0.006$ & 11.00 & $<0.06$ & 0.27 & 0.21 & 0.0037 & 44 & $<0.001$ & 0.015 & 0.0084 \\
P1 & Trt grab & $07 / 14 / 88$ & $<0.006$ & 9.30 & $<0.06$ & 0.31 & 0.18 & 0.0031 & 35 & $<0.001$ & 0.013 & 0.0081 \\
C at C & Trt dil & $07 / 14 / 88$ & 0.0076 & 16.00 & $<0.06$ & 0.35 & 0.37 & 0.0053 & 180 & $<0.001$ & 0.043 & 0.0088 \\
& & & & & & & & & & & & \\
P4 & Ref comp & $11 / 19 / 88$ & $<0.005$ & 0.81 & 0.05 & 0.07 & 0.026 & $<0.001$ & 9.3 & $<0.005$ & $<0.02$ & $<0.01$ \\
P5 & Ref pool & $11 / 19 / 88$ & $<0.005$ & 1.50 & $<0.03$ & 0.05 & 0.16 & $<0.001$ & 3.6 & $<0.005$ & $<0.02$ & $<0.01$ \\
P2 & Trt grab & $11 / 19 / 88$ & $<0.005$ & 0.86 & 0.06 & 0.12 & 0.069 & $<0.001$ & 30.0 & $<0.005$ & $<0.02$ & 0.01 \\
P6 & Trt dil & $11 / 19 / 88$ & $<0.005$ & 0.23 & $<0.03$ & $<0.01$ & 0.11 & $<0.001$ & 31.3 & $<0.005$ & $<0.02$ & $<0.01$ \\
& & & & & & & & & & & & \\
P4 & Ref comp & $01 / 12 / 89$ & $<0.005$ & 0.28 & $<0.03$ & 0.01 & 0.079 & $<0.001$ & 5.5 & $<0.005$ & $<0.02$ & $<0.01$ \\
P3 & Ref grab & $01 / 12 / 89$ & $<0.005$ & 0.23 & $<0.03$ & 0.02 & 0.074 & $<0.001$ & 4.4 & $<0.005$ & $<0.02$ & $<0.01$ \\
P5 & Ref pool & $01 / 12 / 89$ & $<0.005$ & 1.50 & $<0.03$ & $<0.01$ & 0.064 & $<0.001$ & 2.6 & $<0.005$ & $<0.02$ & $<0.01$ \\
P2 & Trt grab & $01 / 12 / 89$ & $<0.005$ & 0.16 & 0.15 & 0.24 & 0.038 & $<0.001$ & 24.1 & $<0.005$ & $<0.02$ & $<0.01$ \\
P1 & Trt grab & $01 / 12 / 89$ & $<0.005$ & 9.40 & $<0.03$ & 0.01 & 0.63 & $<0.001$ & 13.6 & $<0.005$ & $<0.02$ & 0.01 \\
P6 & Trt dil & $01 / 12 / 89$ & $<0.005$ & 4.20 & $<0.03$ & 0.01 & 0.044 & $<0.001$ & 13.9 & $<0.005$ & $<0.02$ & $<0.01$ \\
P6' & Trt dil & $01 / 12 / 89$ & $<0.005$ & 2.30 & $<0.03$ & 0.01 & 0.04 & $<0.001$ & 13.7 & $<0.005$ & $<0.02$ & $<0.01$ \\
& & & & & & & & & & & & \\
P3 & Ref grab & $10 / 02 / 89$ & & 0.03 & & 0.03 & & & 5.987 & BMDL & 0.0319 \\
P1 & Trt grab & $10 / 02 / 89$ & & 0.42 & & 0.025 & & & 10.91 & BMDL & 0.0058 \\
\hline
\end{tabular}


Table 8.7(a) (continued)

\begin{tabular}{lllllllllllll}
\hline Site & TRT & Date & $\mathrm{Ag}$ & $\mathrm{Al}$ & $\mathrm{As}$ & $\mathrm{B}$ & $\mathrm{Ba}$ & $\mathrm{Be}$ & $\mathrm{Ca}$ & $\mathrm{Cd}$ & $\mathrm{Co}$ & $\mathrm{Cr}$ \\
\hline P1 & Trt grab & $11 / 27 / 89$ & & 0.05 & & 0.0125 & & & 8.17 & BMDL & 0.0075 \\
C at C & Trt dil & $11 / 27 / 89$ & & 0.07 & & 0.0108 & & & 15.03 & BMDL & BMDL \\
& & & & & & & & & & & & \\
P1 & Trt grab & $01 / 04 / 90$ & & 0.05 & & 0.0162 & & & 13.6 & BMDL & & 0.0059 \\
& & & & & & & & & & & & \\
P3 & Ref grab & $01 / 21 / 90$ & $<0.005$ & 0.17 & $<0.05$ & $<0.08$ & 0.28 & $<.003$ & 3.7 & $<.007$ & $<.004$ & $<.004$ \\
P1 & Trt grab & $01 / 21 / 90$ & $<0.005$ & 0.62 & $<0.05$ & 0.11 & 1.2 & $<.003$ & 7.7 & $<.007$ & $<.004$ & $<.004$ \\
C at C & Trt dil & $01 / 21 / 90$ & $<0.005$ & 0.12 & $<0.05$ & $<0.08$ & 0.77 & $<.003$ & 9.5 & $<.007$ & $<.004$ & $<.004$ \\
P6 & Trt dil & $01 / 21 / 90$ & $<0.005$ & $<0.03$ & $<0.05$ & $<0.08$ & 1.1 & $<.003$ & 17 & $<.007$ & $<.004$ & $<.004$ \\
\hline
\end{tabular}

${ }^{a}$ Concentrations are in $\mathrm{mg} / \mathrm{L}$, from the total (unfiltered) samples. In addition to the metals listed, $\mathrm{Hg}$ was measured on 1/27/89 and both sample concentrations were $<4.0 \mathrm{mg} / \mathrm{L}$. Concentration of $\mathrm{Ga}$ was measured on $7 / 14 / 88$ and was $<0.3 \mathrm{mg} / \mathrm{L}$ in all three samples. Concentrations of $\mathrm{Zr}$ were measured on $7 / 14 / 88$ and $1 / 21 / 90$ and were $<0.02 \mathrm{mg} / \mathrm{L}$ in all samples. Other samples below the minimum detection limit for the sample run are listed as BMDL or < a particular detection limit if given by the analytical lab. Metals were measured by ICP by ORNL. Analytical Chemistry and/or the University of Georgia. Site sample locations ID's are as described in Table 8.4. (a) $\mathrm{Ag}$ through $\mathrm{Cr}$, (b) $\mathrm{Cu}$ through $\mathrm{P}$, (c) $\mathrm{Pb}$ through $\mathrm{Zn}$. 
Table 8.7(b). Metals in surface runoff at the Pine Plantation Site (Cu through $\mathrm{P}$ )

\begin{tabular}{lllllllllllll}
\hline Site & TRT & Date & $\mathrm{Cu}$ & $\mathrm{Fe}$ & $\mathrm{K}$ & $\mathrm{Li}$ & $\mathrm{Mg}$ & $\mathrm{Mn}$ & $\mathrm{Mo}$ & $\mathrm{Na}$ & $\mathrm{Ni}$ & $\mathrm{P}$ \\
\hline P1' & Trt grab & $07 / 14 / 88$ & 0.031 & 3.10 & 13 & $<0.2$ & 8.8 & 1.5 & $<0.04$ & 1.3 & 0.013 & 3.4 \\
P1 & Trt grab & $07 / 14 / 88$ & 0.028 & 2.70 & 16 & $<0.2$ & 7.8 & 1.3 & $<0.04$ & 1.4 & 0.011 & 3.7 \\
C at C & Trt dil & $07 / 14 / 88$ & 0.040 & 4.40 & 7.8 & $<0.2$ & 13.0 & 4.1 & $<0.04$ & 0.4 & 0.019 & 0.33 \\
& & & & & & & & & & & & \\
P4 & Ref comp & $11 / 19 / 88$ & 0.07 & 1.40 & 35 & $<0.005$ & 5.0 & 0.15 & $<0.01$ & 3.9 & $<0.02$ & \\
P5 & Ref pool & $11 / 19 / 88$ & $<0.01$ & 0.74 & 4 & $<0.005$ & 1.4 & 0.13 & $<0.01$ & 0.5 & $<0.02$ \\
P2 & Trt grab & $11 / 19 / 88$ & 0.02 & 2.00 & 11 & 0.022 & 5.1 & 0.23 & 0.02 & 10.2 & $<0.02$ \\
P6 & Trt dil & $11 / 19 / 88$ & $<0.01$ & 0.20 & $<1$ & $<0.005$ & 14.1 & 0.008 & $<0.01$ & 0.6 & $<0.02$ \\
& & & & & & & & & & & & \\
P4 & Ref comp & $01 / 12 / 89$ & $<0.01$ & 0.21 & $<1$ & $<0.005$ & 1.9 & 0.027 & $<0.01$ & 0.5 & $<0.02$ \\
P3 & Ref grab & $01 / 12 / 89$ & $<0.01$ & 0.19 & $<1$ & $<0.005$ & 1.4 & 0.029 & $<0.01$ & 0.3 & $<0.02$ \\
P5 & Ref pool & $01 / 12 / 89$ & $<0.01$ & 0.56 & 2 & $<0.005$ & 1.4 & 0.021 & $<0.01$ & $<0.2$ & $<0.02$ \\
P2 & Trt grab & $01 / 12 / 89$ & $<0.01$ & 0.16 & 14 & 0.028 & 3.7 & 0.021 & 0.03 & 15.5 & $<0.02$ \\
P1 & Trt grab & $01 / 12 / 89$ & 0.03 & 10.90 & 3 & $<0.005$ & 3.2 & 0.46 & $<0.01$ & 0.6 & $<0.02$ \\
P6 & Trt dil & $01 / 12 / 89$ & $<0.01$ & 2.50 & 2 & $<0.005$ & 3.9 & 0.084 & $<0.01$ & 0.7 & $<0.02$ & \\
P6' & Trt dil & $01 / 12 / 89$ & $<0.01$ & 2.00 & 2 & $<0.005$ & 3.7 & 0.086 & $<0.01$ & 0.7 & $<0.02$ \\
& & & & & & & & & & & \\
P3 & Ref grab & $10 / 02 / 89$ & BMDL & 0.009 & 0.504 & & 1.92 & 0.035 & 0.0241 & 0.49 & BMDL & 0.047 \\
P1 & Trt grab & $10 / 02 / 89$ & 0.0134 & 0.162 & 1.341 & & 3.58 & 0.0401 & 0.0229 & 1.21 & 0.0014 & 0.069 \\
\hline
\end{tabular}


Table 8.7(b) (continued)

\begin{tabular}{|c|c|c|c|c|c|c|c|c|c|c|c|c|}
\hline Site & TRT & Date & $\mathrm{Cu}$ & $\mathrm{Fe}$ & $\mathrm{K}$ & $\mathrm{Li}$ & $\mathrm{Mg}$ & $\mathrm{Mn}$ & Mo & $\mathrm{Na}$ & $\overline{\mathrm{Ni}}$ & $\mathbf{P}$ \\
\hline P1 & Trt grab & $11 / 27 / 89$ & BMDL & 0.013 & 0.976 & & 2.48 & 0.0306 & BMDL & 2.03 & 0.0056 & 0.068 \\
\hline $\mathrm{C}$ at $\mathrm{C}$ & Trt dil & $11 / 27 / 89$ & BMDL & 0.030 & 1.030 & & 3.87 & 0.0016 & BMDL & 1.80 & BMDL & 0.002 \\
\hline P1 & Trt grab & $01 / 04 / 90$ & BMDL & 0.015 & 1.723 & & 3.72 & 0.0151 & BMDL & 2.18 & BMDL & 0.307 \\
\hline P3 & Ref grab & $01 / 21 / 90$ & $<.005$ & 0.056 & & $<15$ & 1.1 & 0.0063 & $<.04$ & $<5$ & $<.009$ & $<.3$ \\
\hline P1 & Trt grab & $01 / 21 / 90$ & $<.005$ & 0.110 & & $<15$ & 1.1 & $<.002$ & $<.04$ & 6.9 & $<.009$ & $<.3$ \\
\hline $\mathrm{C}$ at $\mathrm{C}$ & Trt dil & $01 / 21 / 90$ & $<.005$ & 0.076 & & $<15$ & 1.9 & 0.0032 & $<.04$ & $<5$ & $<.009$ & $<.3$ \\
\hline P6 & Trt dil & $01 / 21 / 90$ & $<.005$ & 0.040 & & $<15$ & 4.7 & $<.002$ & $<.04$ & $<5$ & $<.009$ & $<.3$ \\
\hline
\end{tabular}

${ }^{a}$ Concentrations are in $\mathrm{mg} / \mathrm{L}$, from the total (unfiltered) samples. In addition to the metals listed, $\mathrm{Hg}$ was measured on $1 / 27 / 89$ and both sample concentrations were $<4.0 \mathrm{mg} / \mathrm{L}$. Concentration of $\mathrm{Ga}$ was measured on $7 / 14 / 88$ and was $<0.3 \mathrm{mg} / \mathrm{L}$ in all three samples. Concentrations of $\mathrm{Zr}$ were measured on $7 / 14 / 88$ and $1 / 21 / 90$ and were $<0.02 \mathrm{mg} / \mathrm{L}$ in all samples. Other samples below the minimum detection limit for the sample run are listed as BMDL or < a particular detection limit if given by the analytical lab. Metals were measured by ICP by ORNL Analytical Chemistry and/or the University of Georgia. Site sample locations ID's are as described in Table 8.4. (a) Ag through $\mathrm{Cr}$, (b) $\mathrm{Cu}$ through $\mathrm{P}$, (c) $\mathrm{Pb}$ through $\mathrm{Zn}$. 
Table 8.7(c). Metals in surface runoff at the Pine Plantation Site (Pb through $\mathrm{Zn})^{a}$

\begin{tabular}{llllllllllll}
\hline Site & TRT & Date & Pb & Sb & Se & Si & Sn & Sr & Ti & V & Zn \\
\hline P1' & Trt grab & $07 / 14 / 88$ & 0.034 & $<0.05$ & $<0.05$ & 7.22 & $<0.05$ & 0.069 & $<0.02$ & 0.024 & 0.15 \\
P1 & Trt grab & $07 / 14 / 88$ & 0.033 & $<0.05$ & $<0.05$ & 6.72 & $<0.05$ & 0.058 & $<0.02$ & 0.022 & 0.13 \\
C at C & Trt dil & $07 / 14 / 88$ & 0.061 & $<0.05$ & $<0.05$ & 9.05 & $<0.05$ & 0.240 & $<0.02$ & 0.036 & 0.17 \\
& & & & & & & & & & & \\
P4 & Ref comp & $11 / 19 / 88$ & 0.06 & $<0.03$ & $<0.06$ & 1.4 & 0.04 & 0.027 & 0.014 & $<0.01$ & 5.20 \\
P5 & Ref pool & $11 / 19 / 88$ & $<0.03$ & $<0.03$ & $<0.06$ & 2.9 & $<0.02$ & 0.013 & 0.024 & $<0.01$ & 0.02 \\
P2 & Trt grab & $11 / 19 / 88$ & $<0.03$ & $<0.03$ & $<0.06$ & 5.0 & 0.03 & 0.094 & 0.014 & $<0.01$ & 1.70 \\
P6 & Trt dil & $11 / 19 / 88$ & $<0.03$ & $<0.03$ & $<0.06$ & 3.5 & $<0.02$ & 0.046 & $<0.003$ & $<0.01$ & 0.03 \\
& & & & & & & & & & & \\
P4 & Ref comp & $01 / 12 / 89$ & $<0.03$ & $<0.03$ & $<0.06$ & 2.7 & $<0.02$ & 0.029 & 0.003 & $<0.01$ & 1.20 \\
P3 & Ref grab & $01 / 12 / 89$ & $<0.03$ & $<0.03$ & $<0.06$ & 2.6 & $<0.02$ & 0.028 & $<0.003$ & $<0.01$ & 0.11 \\
P5 & Ref pool & $01 / 12 / 89$ & $<0.03$ & $<0.03$ & $<0.06$ & 3.0 & 0.03 & 0.007 & 0.025 & $<0.01$ & 0.24 \\
P2 & Trt grab & $01 / 12 / 89$ & $<0.03$ & $<0.03$ & $<0.06$ & 8.7 & 0.03 & 0.076 & 0.003 & $<0.01$ & 0.48 \\
P1 & Trt grab & $01 / 12 / 89$ & $<0.03$ & $<0.03$ & $<0.06$ & 9.1 & $<0.02$ & 0.033 & 0.11 & $<0.01$ & 0.11 \\
P6 & Trt dil & $01 / 12 / 89$ & 0.04 & $<0.03$ & $<0.06$ & 12.8 & $<0.02$ & 0.027 & 0.23 & $<0.01$ & 0.04 \\
P6' & Trt dil & $01 / 12 / 89$ & 0.03 & $<0.03$ & $<0.06$ & 6.4 & 0.05 & 0.026 & 0.082 & $<0.01$ & 0.04 \\
& & & & & & & & & & & \\
P3 & Ref grab & $10 / 02 / 89$ & 0.001 & & & & & & & & 0.065 \\
P1 & Trt grab & $10 / 02 / 89$ & 0.0001 & & & & & & & 0.017 \\
\hline
\end{tabular}


Table 8.7(c) (continued)

\begin{tabular}{|c|c|c|c|c|c|c|c|c|c|c|c|}
\hline Site & TRT & Date & $\mathrm{Pb}$ & $\mathrm{Sb}$ & $\mathrm{Se}$ & $\mathrm{Si}$ & Sn & $\mathrm{Sr}$ & $\overline{\mathrm{Ti}}$ & $\mathrm{V}$ & $\overline{\mathrm{Zn}}$ \\
\hline $\mathrm{P} 1$ & Trt grab & $11 / 27 / 89$ & 0.002 & & & & & & & & 0.025 \\
\hline $\mathrm{C}$ at $\mathrm{C}$ & Trt dil & $11 / 27 / 89$ & BMDL & & & & & & & & 0.014 \\
\hline P1 & Trt grab & $01 / 04 / 90$ & BMDL & & & & & & & & 0.028 \\
\hline P3 & Ref grab & $01 / 21 / 90$ & $<.03$ & $<.05$ & $<.01$ & 1.3 & $<.05$ & 0.022 & $<.02$ & $<.004$ & 0.074 \\
\hline P1 & Trt grab & $01 / 21 / 90$ & $<.03$ & $<.05$ & $<.01$ & 1 & $<.05$ & 0.036 & $<.02$ & $<.004$ & 0.049 \\
\hline $\mathrm{C}$ at $\mathrm{C}$ & Trt dil & $01 / 21 / 90$ & $<.03$ & $<.05$ & $<.01$ & 1.6 & $<.05$ & 0.033 & $<.02$ & $<.004$ & 0.032 \\
\hline P6 & Trt dil & $01 / 21 / 90$ & $<.03$ & $<.05$ & $<.01$ & 2.2 & $<.05$ & 0.041 & $<.02$ & $<.004$ & 0.032 \\
\hline
\end{tabular}

${ }^{a}$ Concentrations are in $\mathrm{mg} / \mathrm{L}$, from the total (unfiltered) samples. In addition to the metals listed, $\mathrm{Hg}$ was measured on 1/27/89 and both sample concentrations were $<4.0 \mathrm{mg} / \mathrm{L}$. Concentration of $\mathrm{Ga}$ was measured on $7 / 14 / 88$ and was $<0.3 \mathrm{mg} / \mathrm{L}$ in all three samples. Concentrations of $\mathrm{Zr}$ were measured on $7 / 14 / 88$ and $1 / 21 / 90$ and were $<0.02 \mathrm{mg} / \mathrm{L}$ in all samples. Other samples below the minimum detection limit for the sample run are listed as BMDL or < a particular detection limit if given by the analytical lab. Metals were measured by ICP by ORNL Analytical Chemistry and/or the University of Georgia. Site sample locations ID's are as described in Table 8.4. (a) Ag through $\mathrm{Cr}$, (b) $\mathrm{Cu}$ through $\mathrm{P}$, (c) $\mathrm{Pb}$ through $\mathrm{Zn}$. 
Table 8.8. Metals in surface runoff at the Cottonwood Site (mg/L), listed by sample collection datea

\begin{tabular}{|c|c|c|c|c|c|c|c|c|c|}
\hline $\mathrm{ID}$ & TRT & Date & $\mathrm{Al}$ & B & $\mathrm{Ba}$ & $\mathrm{Ca}$ & $\mathrm{Cr}$ & $\mathrm{Fe}$ & $\mathbf{K}$ \\
\hline $\mathrm{CR}^{\prime}$ & Ref & $08 / 01 / 89$ & 0.4182 & 0.0212 & & 18.25 & BMDL & 0.1845 & 5.325 \\
\hline CR & Ref & $08 / 01 / 89$ & 0.4068 & 0.0262 & & 18.55 & BMDL & 0.1831 & 5.197 \\
\hline $\mathrm{CNC}^{\prime}$ & Trt dil & $08 / 01 / 89$ & 0.0729 & 0.0371 & & 25.53 & $\mathrm{BMDL}$ & 0.1461 & 1.806 \\
\hline CNC & Trt dil & $08 / 01 / 89$ & 0.1367 & 0.0454 & & 25.43 & BMDL & 0.1698 & 1.915 \\
\hline CR & Ref & $01 / 04 / 90$ & 0.3236 & 0.0029 & & 31.48 & BMDL & 0.1862 & 2.501 \\
\hline CNC & Trt dil & 01/04/90 & 0.2815 & 0.0146 & & 10.02 & 0.0177 & 0.2439 & 0.902 \\
\hline CR & Ref & $01 / 21 / 90$ & 0.220 & $<.08$ & 0.32 & 9.9 & $<.004$ & 0.073 & \\
\hline CNC' & Trt dil & $01 / 21 / 90$ & 0.300 & $<.08$ & 0.37 & 3.5 & $<.004$ & 0.140 & \\
\hline $\mathrm{CNC}$ & Trt dil & $01 / 21 / 90$ & 0.035 & $<.08$ & 0.35 & 3.5 & $<.004$ & 0.170 & \\
\hline $\csc$ & Trt & $01 / 21 / 90$ & 0.700 & 0.085 & 1.00 & 5.6 & $<.004$ & 0.170 & \\
\hline ID & TRT & date & $\mathrm{Mg}$ & $\mathrm{Mn}$ & $\mathrm{Na}$ & $\mathbf{P}$ & $\mathrm{Si}$ & $\mathrm{Sr}$ & $\mathrm{Zn}$ \\
\hline $\mathrm{CR}^{\prime}$ & Ref & $08 / 01 / 89$ & 2.66 & 0.004 & 1.20 & 0.016 & & & 0.0324 \\
\hline CR & Ref & $08 / 01 / 89$ & 2.67 & 0.010 & 1.11 & 0.013 & & & 0.0386 \\
\hline CNC' & Trt dil & $08 / 01 / 89$ & 2.99 & 1.288 & 2.88 & 0.015 & & & 0.2189 \\
\hline CNC & Trt dil & $08 / 01 / 89$ & 2.98 & 1.226 & 2.89 & BMDL & & & 0.2220 \\
\hline CR & Ref & $01 / 04 / 90$ & 4.09 & 0.007 & 46.68 & 0.020 & & & 0.0184 \\
\hline CNC & Trt dil & $01 / 04 / 90$ & 1.48 & 0.029 & 2.59 & 0.010 & & & 0.0190 \\
\hline CR & Ref & $01 / 21 / 90$ & 1.00 & $<.002$ & $<5.0$ & $<0.30$ & 0.84 & 0.018 & 0.011 \\
\hline $\mathrm{CNC}^{\prime}$ & Trt dil & $.01 / 21 / 90$ & 0.70 & 0.027 & $<5.0$ & 0.47 & 1.7 & 0.017 & 0.120 \\
\hline $\mathrm{CNC}$ & Trt dil & $01 / 21 / 90$ & 6.90 & 0.030 & $<5.0$ & 0.47 & 1.7 & 0.016 & 0.099 \\
\hline $\csc$ & Trt & $01 / 21 / 90$ & 1.20 & 0.036 & 7.1 & 1.90 & 1.3 & 0.024 & 0.013 \\
\hline
\end{tabular}

${ }^{\text {In }}$ addition to the metals shown, $\mathrm{Cd}, \mathrm{Cu}, \mathrm{Mo}, \mathrm{Ni}$, and $\mathrm{Pb}$ were atways below the minimum detection limits (BMDL). Samples from January 21,1990 were also analyzed for $\mathrm{Ag}, \mathrm{As}, \mathrm{Be}, \mathrm{Co}, \mathrm{Li}, \mathrm{Sb}$, $\mathrm{Se}, \mathrm{Sn}, \mathrm{Ti}, \mathrm{V}$, and $\mathrm{Zr}$, and were $\mathrm{BMDL}$ for all samples. Concentrations listed as $<$ a value were also BMDL for that lab. Sample location ID designations are as described in Table 8.1. "Trt dil" indicates that the sampling location was downstream of the sludge treatment area, subject to dilution from other water sources. 
Table 8.9. Mercury in surface runoff at the Rogers site during active sludge application ${ }^{a}$

\begin{tabular}{|c|c|c|c|c|c|}
\hline $\begin{array}{c}\text { Sample } \\
\text { ID }\end{array}$ & Treatment, sample type & Sample date & $\begin{array}{c}\text { Hg in soluble } \\
\text { fraction } \\
(\mu \mathrm{g} / \mathrm{L})\end{array}$ & $\begin{array}{c}\mathrm{Hg} \text { in } \\
\text { particulate } \\
\text { fraction ( } \mu \mathrm{g} / \mathrm{L} \\
\text { basis) }\end{array}$ & $\begin{array}{l}\text { Hg in } \\
\text { particulate } \\
\text { fraction } \\
(\mu \mathrm{g} / g)\end{array}$ \\
\hline B & Reference (grab) & $2 / 27 / 87$ & 1 & 8 & \\
\hline A & Treatment (composite) & $9 / 14 / 87$ & & & 0.286 \\
\hline B & Reference (composite) & $9 / 14 / 87$ & & & 1.52 \\
\hline B & Reference (composite) & $9 / 30 / 87$ & $<0.10$ & 0.08 & 0.45 \\
\hline A & Treatment (composite) & $11 / 17 / 87$ & 0.3 & 0.02 & 0.112 \\
\hline F & Treatment (Pool) & $1 / 4 / 88$ & 2.2 & & 2.62 \\
\hline B & Reference (composite) & $1 / 4 / 88$ & 0.04 & & 0.34 \\
\hline A & Treatment (composite) & $2 / 19 / 88$ & 0.2 & & \\
\hline B & Reference (composite) & $2 / 19 / 88$ & 0.1 & & \\
\hline
\end{tabular}

${ }^{a}$ In addition, both reference and treatment samples taken on 11/19/88 and 1/12/89 were below the detection limit of $0.008 \mathrm{ppm} \mathrm{Hg}$, analyzed by the Soil Testing and Plant Analysis Laboratory at the University of Georgia, Athens.

Table 8.10. Radionuclides in surface runoff at: Rogers, Pine Plantation, Cottonwoods and McCoy sites (data are from grab samples except as indicated)

\begin{tabular}{|c|c|c|c|c|c|c|}
\hline Site & Treatment & ID & $\begin{array}{c}\text { Sample } \\
\text { date }\end{array}$ & $\begin{array}{c}{ }^{137} \mathrm{Cs} \\
\text { (pCi/L) }\end{array}$ & $\begin{array}{c}{ }^{60} \mathrm{Co} \\
\text { (pCi/L) }\end{array}$ & $\underset{(m g / L)}{U}$ \\
\hline Rogers & $\begin{array}{l}\text { Treatment } \\
\text { Treatment } \\
\text { Reference } \\
\text { Reference }\end{array}$ & $\begin{array}{l}\text { R1 } \\
\text { R1 } \\
\text { R4 } \\
\text { R4 }\end{array}$ & $\begin{array}{l}1 / 13 / 89 \\
1 / 29 / 90 \\
1 / 13 / 89 \\
1 / 29 / 90\end{array}$ & $\begin{array}{l}<8.5 \\
<2.66 \\
<10.40 \\
<0.04\end{array}$ & $\begin{array}{l}<5.5 \\
<2.47 \\
<9.0 \\
-\end{array}$ & $\begin{array}{l}0.16 \\
0.011 \\
0.09 \\
<0.0005\end{array}$ \\
\hline Pine & $\begin{array}{l}\text { Treatment } \\
\text { Treatment } \\
\text { Treatment } \\
\text { Reference } \\
\text { Reference } \\
\text { Reference } \\
\text { Treatment } \\
\text { (downstream) } \\
\text { Treatment } \\
\text { (downstream) }\end{array}$ & $\begin{array}{l}\text { P1 } \\
\text { P1 } \\
\text { P1 } \\
\text { P3 } \\
\text { P3 } \\
\text { P4 } \\
\text { P6 } \\
\text { (rock wall) } \\
\text { Creek at Corner }\end{array}$ & $\begin{array}{l}12 / 88 \\
1 / 13 / 89 \\
1 / 29 / 90 \\
1 / 13 / 89 \\
1 / 29 / 90 \\
12 / 88 \\
1 / 29 / 90 \\
1 / 29 / 90\end{array}$ & $\begin{array}{l}<2.3 \\
3.9 \\
<2.3 \\
<2.5 \\
-3 . \\
<3.0 \\
<3.1\end{array}$ & $\begin{array}{l}\overline{<2.3} \\
<2.1 \\
<2.4 \\
<1.9 \\
-2.5 \\
<2.8\end{array}$ & $\begin{array}{l}0.07 \\
0.03 \\
0.275 \\
\\
0.023 \\
0.09 \\
0.093 \\
0.029\end{array}$ \\
\hline Cottonwood & $\begin{array}{l}\text { Treatment } \\
\text { Treatment } \\
\text { Treatment } \\
\text { Treatment } \\
\text { Reference }\end{array}$ & $\begin{array}{l}\text { North Creek } \\
\text { North Creek } \\
\text { South Creek } \\
\text { South Creek } \\
\text { Ref. Creek }\end{array}$ & $\begin{array}{l}1 / 29 / 90 \\
2 / 16 / 90 \\
1 / 29 / 90 \\
2 / 16 / 90 \\
1 / 29 / 90\end{array}$ & $\begin{array}{l}1.6 \\
<2.9 \\
2.4 \\
2.2 \\
<2.2\end{array}$ & $\begin{array}{l}<3.0 \\
<2.8 \\
<3.0 \\
<2.0 \\
<2.7\end{array}$ & $\begin{array}{l}<0.0005 \\
0.006 \\
0.122\end{array}$ \\
\hline Rogers & $\begin{array}{l}\text { Treatment } \\
\text { Treatment } \\
\text { Treatment } \\
\text { Reference } \\
\text { Reference }\end{array}$ & $\begin{array}{l}\text { Pool } \\
\text { Weir } \\
\mathrm{A}^{a} \\
\mathrm{~B}^{a} \\
\mathrm{~F}^{a}\end{array}$ & $\begin{array}{l}3 / 10 / 88 \\
3 / 10 / 88 \\
2 / 4 / 88 \\
2 / 4 / 88 \\
2 / 4 / 88\end{array}$ & $\begin{array}{l}- \\
<5.0 \\
<2.7 \\
<2.7 \\
<5.4\end{array}$ & $\begin{array}{l}4.9 \\
<5.0 \\
<5.4 \\
<2.7 \\
<5.4\end{array}$ & \\
\hline McCoy & $\begin{array}{l}\text { Reference } \\
\text { Treatment } \\
\text { Treatment }\end{array}$ & $\begin{array}{l}\text { Upstream } \\
\text { Downstream }^{a} \\
\text { Downstream }\end{array}$ & $\begin{array}{l}3 / 10 / 88 \\
3 / 10 / 88 \\
3 / 10 / 88\end{array}$ & $\begin{array}{l}<3.7 \\
<2.7 \\
<5.0\end{array}$ & $\begin{array}{l}<2.7 \\
<2.7 \\
<3.7\end{array}$ & \\
\hline
\end{tabular}

aThese samples taken from compositors. 
Table 8.11. Biological oxygen demand ( $\mathrm{mg} / \mathrm{L}$ ) and fecal coliform bacteria (colonies/100 $\mathrm{mL}$ )in surface runoff from the Cottonwood, Pine Plantation, and Rogers sites ${ }^{a}$

\begin{tabular}{|c|c|c|c|c|c|}
\hline Sample ID & Site & TRT & & $\begin{array}{l}\text { Fecal } \\
\text { coliform }\end{array}$ & BOD \\
\hline $\mathrm{CR}$ & Cottonwood & Ref & $01 / 04 / 90$ & 30 & 4 \\
\hline CR & Cottonwood & Ref & $01 / 30 / 90$ & 3 & $<2$ \\
\hline $\mathrm{CR}$ & Cottonwood & Ref & $05 / 02 / 90$ & 5200 & 3 \\
\hline $\csc$ & Cottonwood & Trt & $01 / 30 / 90$ & 40 & $>15$ \\
\hline $\operatorname{CSC}$ & Cottonwood & Trt & $05 / 02 / 90$ & 8300 & 3 \\
\hline $\mathrm{CNC}$ & Cottonwood & Trt dil & $09 / 22 / 89$ & 2260 & $<4$ \\
\hline $\mathrm{CNC}$ & Cottonwood & Trt dil & $01 / 04 / 90$ & 140 & $<2$ \\
\hline $\mathrm{CNC}$ & Cottonwood & Trt dil & $01 / 30 / 90$ & 520 & 2 \\
\hline $\mathrm{CNC}$ & Cottonwood & Trt dil & $02 / 22 / 90$ & 380 & $<2$ \\
\hline $\mathrm{CNC}$ & Cottonwood & Trt dil & $05 / 02 / 90$ & 6200 & 3 \\
\hline P3A & Pine & Ref grab & $06 / 09 / 89$ & 330 & $<5$ \\
\hline P3B & Pine & Ref grab & $06 / 09 / 89$ & 300 & $<5$ \\
\hline P3 & Pine & Ref grab & $01 / 30 / 90$ & 10 & 4 \\
\hline P3 & Pine & Ref grab & $10 / 02 / 90$ & $<100$ & $<4$ \\
\hline 1132SPA & Pine & Trt & $06 / 09 / 89$ & 24000 & 13.2 \\
\hline $1132 \mathrm{SPB}$ & Pine & Trt & $06 / 09 / 89$ & 26000 & 12.7 \\
\hline P1A & Pine & Trt grab & $06 / 09 / 89$ & 13000 & 12.2 \\
\hline P1B & Pine & Trt grab & $06 / 09 / 89$ & 15000 & 10.8 \\
\hline P1A & Pine & Trt grab & $09 / 22 / 89$ & 260000 & 12 \\
\hline P1B & Pine & Trt grab & $09 / 22 / 89$ & 250000 & 12 \\
\hline P1 & Pine & Trt grab & $01 / 04 / 90$ & 260 & $<2$ \\
\hline P1 & Pine & Trt grab & $01 / 30 / 90$ & 800 & 5 \\
\hline P1 & Pine & Trt grab & $02 / 22 / 90$ & 2300 & $<2$ \\
\hline P1 & Pine & Trt grab & $10 / 02 / 90$ & 500 & $<4$ \\
\hline P1 & Pine & Trt grab & $11 / 27 / 90$ & 28 & $<2$ \\
\hline C AT C & Pine & Trt dil & $01 / 30 / 90$ & 673 & 4 \\
\hline CAT C & Pine & Trt dil & $02 / 22 / 90$ & 1950 & $<2$ \\
\hline C AT C & Pine & Trt dil & $11 / 27 / 90$ & 13 & $<2$ \\
\hline P6 & Pine & Trt dil & $09 / 22 / 89$ & 11400 & 5 \\
\hline P6 & Pine & Trt dil & $01 / 04 / 90$ & 10 & $<2$ \\
\hline P6 & Pine & Trt dil & $01 / 30 / 90$ & 150 & 3 \\
\hline
\end{tabular}


Table 8.11 (continued)

\begin{tabular}{lllrrr}
\hline Sample ID & & Site & TRT & \multicolumn{2}{c}{ Fecal } \\
coliform & BOD \\
\hline R1 & Rogers & Trt Grab & $01 / 04 / 90$ & 330 & 4 \\
R1 & Rogers & Trt Grab & $01 / 30 / 90$ & 270 & 2 \\
R1 & Rogers & Trt Grab & $02 / 22 / 90$ & 650 & 2 \\
R1 & Rogers & Trt Grab & $05 / 02 / 90$ & $>57000$ & 7 \\
R1A & Rogers & Trt Grab & $02 / 17 / 89$ & $>600$ & $<5$ \\
R1B & Rogers & Trt Grab & $02 / 17 / 89$ & 100 & $<5$ \\
R2 & Rogers & Trt Comp & $07 / 14 / 88$ & $>1200$ & $<5$ \\
R2' & Rogers & Trt Comp & $07 / 14 / 88$ & $>1200$ & \\
R3 & Rogers & Trt Pool & $07 / 14 / 88$ & $>1200$ & 7 \\
R4 & Rogers & Ref Grab & $09 / 22 / 89$ & 41000 & 2 \\
R4 & Rogers & Ref Grab & $01 / 04 / 90$ & 180 & 3 \\
R4 & Rogers & Ref Grab & $01 / 30 / 90$ & 33 & $<2$ \\
R4 & Rogers & Ref Grab & $02 / 22 / 90$ & 120 & $<2$ \\
R4 & Rogers & Ref Grab & $05 / 02 / 90$ & $>51666700$ & 5 \\
R4 & Rogers & Ref Grab & $10 / 02 / 90$ & 800 & $<2$ \\
R4 & Rogers & Ref Grab & $11 / 27 / 90$ & 700 & $<2$ \\
R4A & Rogers & Ref Grab & $02 / 17 / 89$ & 260 & $<5$ \\
R4B & Rogers & Ref Grab & $02 / 17 / 89$ & 520 & \\
R5 & Rogers & Ref Comp & $07 / 14 / 88$ & 22 & 7 \\
R5' & Rogers & Ref Comp & $07 / 14 / 88$ & 118 & \\
\hline
\end{tabular}

${ }^{a}$ Data are arranged by site, sample treatment type or area (reference, Ref; or sludge treated, Trt) and date. "Trt" samples were in or downstream from the application areas, "dil" means flow has been potentially diluted. "Grab" or "Comp" indicate grab samples or sample from compositors. If not labelled, samples were grab sampies. Sample IDs are further described in legends for previous tables in this section, and A, B, and 'designate replicate samples. Some of this data also appears in Tables 8.1 through 8.3. 


\section{REFERENCES}

Boston H. L., H. Van Miegroet, I. L. Larsen, A. E. Walzer, and J. E. Carlton. 1990. The fate of radionuclides in sewage sludge applied to land. Environmental Contamination, 4th International Conference, Barcelona, Spain, October, 1990.

Chang, A. C., T. J. Logan, and A. L. Page 1986. Trace element considerations of forest land applications of municipal sludge. pp. 85-99. IN D.W. Cole, et al., (eds.), The forest alternative for treatment and utilization of municipal and industrial wastes. University of Washington Press, Seattle, Washington.

EPA (U.S. Environmental Protection Agency). 1986. Resource Conservation and Recovery Act (RCRA) ground-water monitoring technical enforcement guidance document. PB87107751 (OSWER-9950.1).

Larsen, I. L., S. Y. Lee, H. L. Boston, and E. A. Stetar. 1992. Discovery of a ${ }^{137} \mathrm{Cs}$ hot particle in municipal wastewater treatment sludge. Health Physics 62, 235-238.

Mumma, R. O., D. C. Raupach, J. P. Waldman, S. S. C. Tong, M. L. Jacobs, J. G. Babish, L. H. Hotchkiss, P. C. Wszolek, W. H. Gutenman, C. A. Bache, and D. J. Lisk. 1984. National survey of elements and other constituents in municipal sewage sludges. Arch Environ. Contam. Toxicol. 13, 75-83.

Oakes, T. W., H. M. Braunstein, K. L. Daniels, W. F. Ohnesorge, J. T. Kitchings, and W. A. Alexander. 1984. Report on the Oak Ridge Sewage-Sludge Land-Farming Experience. Part I-Data Presentation, ORNL, 6062, Department of Environmental Management, Oak Ridge National Laboratory, Oak Ridge, Tennessee.

Van Miegroet, H., H. L. Boston, and D. W. Johnson. 1989. Environmental and plant effects of sewage sludge application to forests and pastures. Proceedings, Twelfth Annual Madison Waste Conference, September, 1989, Madison, WI. 

Appendix A

METHODS OF SLUDGE ANALYSIS FOR RADIONUCLIDE CONTENT AT OAK RIDGE NATIONAL LABORATORY 



\section{METHODS OF SLUDGE ANALYSIS FOR RADIONUCLIDE CONTENT AT OAK RIDGE NATIONAL LABORATORY}

Samples of sludge were transferred to a 1 liter Marinelli beaker (reentrant beaker) weighed, and if necessary diluted to 1 liter with deionized distilled water. In most instances virtually 1 liter of material was supplied. However, there were a few instances where the material would only partially fill a 1 liter Marinelli beaker, and in these instances, samples were counted in 0.5 liter Marinelli beakers. The sample size in kilograms was then used to quantify the data. One liter of sludge is approximately the same as $1 \mathrm{Kg}$ of sludge. From 1988 through 1990, the majority of the samples were counted for 200 minutes. These samples were then dried and analysis was performed by neutron activation on selected samples for Uranium content. After 1990, the samples were ana overnight and the Uranium content quantified by gamma-ray spectrometry. To quantify the ${ }^{238} \mathrm{U}$, the granddaughter radionuclide ${ }^{234} \mathrm{~Pa} \mathrm{~m}$ at $1001 \mathrm{Kev}$ was utilized. Because the photon yield from this nuclide is low $(<1 \%)$ large uncertainty terms in the quantified value occur especially at low concentrations $(<1 \mathrm{nCi} / \mathrm{L})$. For ${ }^{235} \mathrm{U}$, the photon energy at $143 \mathrm{Kev}$ was utilized. The Uranium concentrations were reported even though the analytical uncertainties were large in order to indicate the order of magnitude of Uranium present. A comparison with 4 samples analyzed by direct nondestructive gamma-ray spectrometry and then by alpha spectrometry is given in Table A-1. Quantification of additional radionuclides were accomplished utilizing the following photon energies. ${ }^{\mathrm{Co}}, 1173$ \& $1332 \mathrm{Kev} ;{ }^{137} \mathrm{Cs}, 662 \mathrm{Kev} ;{ }^{131} \mathrm{I}, 364 \mathrm{Kev} ;{ }^{7} \mathrm{Be}, 477 \mathrm{Kev} ;{ }^{40} \mathrm{~K}, 1461 \mathrm{Kev}$; ${ }^{228} \mathrm{Ra}\left({ }^{228} \mathrm{Ac}\right), 911 \mathrm{Kev}$.

Analyses were performed on an intrinsic germanium (IG) detector having a relative efficiency and resolution FWHM at $1332 \mathrm{Kev}$ of $25 \%$ and $2.0 \mathrm{Kev}$, respectively. The detector was mounted inside a lead shield and coupled to a Nuclear Data 6700 microprocessor programmed to acquire spectra in 4096 channels. Corrections for ambient background peaks associated with the system were made from a spectrum counted for a duration longer than the sample count. Software routines for quantifying data were those of the vendor, Nuclear Data, Inc. Efficiency calibration of the detector utilized Amersham mixed gamma standard (QCY 46 or 48 ) series with traceability to NIST. A known quantity of this material was diluted in a $4 \mathrm{M} \mathrm{HCl}$ in the Marinelli beaker and counted for an appropriate amount of time to minimize counting uncertainties. Verification of calibration was performed by analyzing QA/QC samples distributed by the EPA at Las Vegas, Nevada. 
Table A-1. Comparison of uranium isotope data by alpha spectrometry versus direct counting nondestructive gamma-ray analysis on the same sludge sample. (Units are in $\mathrm{pCi} / \mathrm{g}$ of wet sludge.)

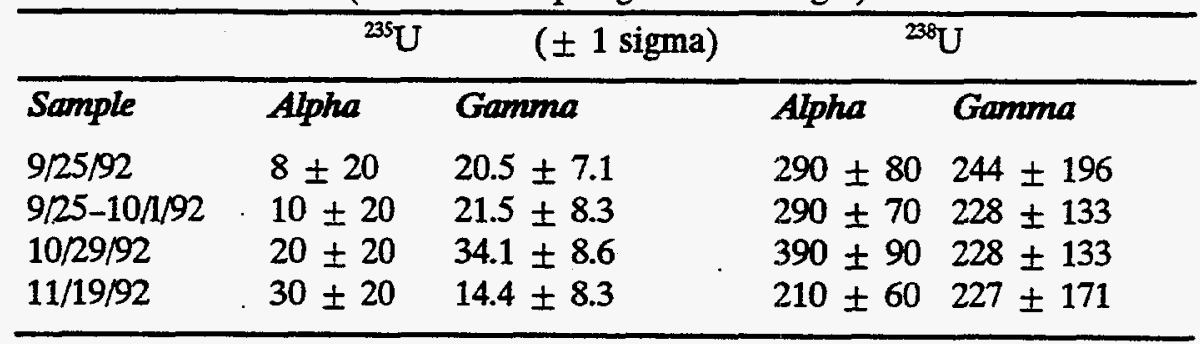

To convert to a dry weight basis, 1 kilogram of wet sludge on average yields $24.5 \mathrm{~g}$ of dry material. 
Appendix B

WEEKLY SLUDGE RADIOISOTOPE ANALYSIS 



\section{ANNUAL SLUDGE DATA SUMMARY 1988 thru 1993 (1989-1993 includes Uranium Data)}

Radionuelide data for Oak Ridge digerted sludge

Weekly integrated samples

Data from 1.L Larsen. Epvironmeatal Scieocer Division

Data are in $\mathrm{pCi} / \mathrm{K}_{\mathbf{g}}$ and $\mathrm{Bq} / \mathrm{K}_{\mathrm{g}}$ wet $\mathrm{nr}$

Note: $1 \mathrm{~K}_{\mathrm{g}}$ wet siudge is typically about 1 liter

Note: N.D. not detected: Below minimum detection limit

Blank weekly areas indieate no sampie

\section{RADIONUCLIDES RN SLUTGE 1988}

\begin{tabular}{|c|c|c|c|c|c|c|c|c|c|c|c|c|c|}
\hline $\begin{array}{c}\text { Date } \\
\text { Collected }\end{array}$ & WEEK & $\begin{array}{l}C O-60 \\
\text { Bqukg }\end{array}$ & $\begin{array}{l}C O-60 \\
\text { POUKg }\end{array}$ & $\begin{array}{l}\mathrm{CS}-137 \\
\text { BquKg }\end{array}$ & $\begin{array}{l}\mathrm{CS}-137 \\
\mathrm{PG} \mathrm{Ke}\end{array}$ & $\mid \begin{array}{l}1-131 \\
\text { Bqukg }\end{array}$ & $\begin{array}{l}1-131 \\
\text { PQIKg }\end{array}$ & $\begin{array}{l}B E-7 \\
\text { BquKg }\end{array}$ & $\begin{array}{l}\text { BE-7 } \\
\text { PQUKg }\end{array}$ & $\begin{array}{l}K-40 \\
B g i K_{g}\end{array}$ & $\begin{array}{l}K=40 \\
\text { PQUK }\end{array}$ & $\begin{array}{l}\mathrm{RA}-228 \\
\mathrm{Bg} \mathrm{KLg}_{\mathrm{g}}\end{array}$ & $\begin{array}{l}\mathrm{RA-228} \\
\mathrm{PQUK}\end{array}$ \\
\hline & 11 & 1 & & & & & & & & & & & \\
\hline I & E & & & & & & & & & & & & \\
\hline & 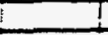 & & & & & & & & & & & & \\
\hline & 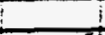 & & & & & & & & & & & & \\
\hline & SI & 1 & & & & & & & & & & & \\
\hline & & $i$ & & 1 & & & & & & & & & \\
\hline & & & & & & & & & & & & & \\
\hline & & & & I & - & & & & & & & & \\
\hline & & & & & & & & & & & & & \\
\hline & i0 & & & & & & & & & & & & \\
\hline & & & & & & & & & & & & & \\
\hline & & & & & & & & & & & & & \\
\hline & is & 1 & i & & & & & & & & & & \\
\hline & - & & & & & & & & & & & & \\
\hline & $15 !$ & & & & & & & & & & & & \\
\hline & & $i$ & 1 & & & & & & & & & & \\
\hline & & i & & & & & & & & & & & \\
\hline & & & & & & & & & & & & & \\
\hline & & & & & & & & & & & & & \\
\hline 0520 & 201 & 1.9 & 51 & 1.61 & 4.30 & 7.9 & 214 & N.D. & N.D. & 6.1 & 164 & 0.21 & 5.8 \\
\hline .0527 & & 1.6 & 44 & 1.4 & 37.4 & 18.1 & 489 & N.D. & N.D. & 53 & 142 & N.D. & TN.D. \\
\hline 0602 & & 2.21 & $60 !$ & 1.81 & 49.61 & 9.1 & 246 & 1.1 & 31 & 7.7 & 207 & 0.92 & 249 \\
\hline $0605-06,09$ & & 5.7 & 741 & 21 & 56.1 & 158 & 428 & 1.1 & 29 & 176 & 477 & 0.31 & 83 \\
\hline $06 / 10-06 / 16$ & & 1.7 & 46 & 1.7 & 452 & 12.4 & 3351 & N.D. & N.D. & 4.4 & 118 & N.D. & N.D. \\
\hline $00 / 19-06 / 23$ & 351 & 17.5 & 4741 & 110 & 2980 & 7.8 & $2 \pi 1$ & N.D. & N.D. & 5.6 & is & N.D. & N.D. \\
\hline $06.24-06.29$ & & 4.31 & 117! & 5.3 & 8791 & 5.4 & 146 & 1.6 & 44 & 8.4 & 228 & N.D. & N.D. \\
\hline $0701-07,05$ & & 201 & 541 & 1.61 & 4.3 .4 & 6.01 & 1611 & 0.9 & 24) & 6.1 & 164 & N.D. & N.D. \\
\hline $07 / 11-07114$ & & 1.81 & 501 & 2.4 & 65.11 & 1.9 & 52 & 0.7 & 20 & 4.7 & 127 & N.D. & N.D. \\
\hline $07115-0721$ & & 1.7 & 471 & 1.5 & 412 & 1.4 & 37! & N.D. & N.D. & 5.8 & 157 & N.D. & N.D. \\
\hline $07.2-0728$ & $30 !$ & 3.3 & $89 !$ & 2.7 & 740 & 0.81 & 211 & N.D. & N.D. & 7.0 & 189 & N.D. & IN.D. \\
\hline $07: 29-n 804$ & & 2.91 & 781 & 2.1 & 556 & 6.7 & 181 & N.D. & N.D. & 7.1 & 192 & N.D. & IN.D. \\
\hline $0805-08.11$ & & 1.81 & 491 & 3.11 & 29.1 & 8.9 & 2411 & N.D. & IN.D. & 8.8 & 237 & N.D. & N.D. \\
\hline $08 / 12-08 / 18$ & & 2.7 & 74 & 2.2 & 600 & 5.4 & 145 & 23 & 69 & 5.4 & 147 & N.D. & N.D. \\
\hline $08 / 19-08 / 25$ & & 3.2 & .861 & 3.7 & 49 & 4.4 & 120 & 2.2 & 61 & 8.51 & 229 & 024 & 64 \\
\hline $0826-199.01$ & 35! & 3.11 & 8.3 & 1.5 & +18 & 23.7 & 6411 & N.D. & N.D. & 12.7 & 344 & 1.28 & 34.7 \\
\hline $09102-0906$ & 1 & 3.2 & 861 & 1.21 & 33.51 & 1.7 & 461 & N.D. & N.D. & 6.4 & 174 & 0.81 & 218 \\
\hline $090,06-09 \cap 5$ & & 3.3 & 891 & $2.1 !$ & 568 & 0.8 & 201 & N.D. & N.D. & N.D. & N.D. & 0.65 & 176 \\
\hline $09.16-09.22$ & & 3.9 & 105 & 1.5 & 39.4 & 0.5 & 13 & N.D. & N.D. & 6.0 & 162 & N.D. & IN.D. \\
\hline $09,25-09 / 29$ & & 3.9 & 105 & 1.7 & 45.7 & 0.9 & 24 & 0.6 & 17) & 7.8 & 210 & 1.79 & 48.3 \\
\hline$0 9 \longdiv { 3 0 - 1 0 0 6 }$ & \$0। & 4.8 & 131 & 2.01 & 5291 & 0.1 & 2) & 0.4 & 10 & 6.0 & 1611 & N.D. & N.D. \\
\hline $1007-1013$ & & 9.2 & 249 & 2.6 & 700 & 0.2 & 4ा & N.D. & N.D. & 8.31 & $\frac{2041}{2251}$ & 0.36 & 9.8 \\
\hline $10 / 14-10 / 24$ & & 8.11 & 219 & 1.9 & 5081 & 0.1 & $3 \mid$ & N.D. & N.D. & 3.4 & 91 & 0.71 & 19.3 \\
\hline $1024-10 / 27$ & & 5.1 & 138 & \begin{tabular}{|l|l}
1.3 \\
\end{tabular} & 34.31 & 0.1 & 2 & N.D. & N.D. & 7.6 & 205 & 0.19 & 5.2 \\
\hline $1031-1103$ & & 8.1 & 2201 & 1.3 & .34 .4 & 1.0 & 2811 & N.D. & N.D. & 7.1 & 193 & 0.03 & 0.8 \\
\hline $11 / 04-11 / 10$ & 45) & 9.8 & 266 & 1.2 & 33.1 & 1.4 & 381 & N.D. & ND. & 351 & 951 & 0.82 & 22.1 \\
\hline $11 ! 11-11117$ & & 9.5 & 2561 & $0.4 !$ & 109 & 15 & 3915 & N.D. & N.D. & 6.21 & 167 & 0.14 & 3.9 \\
\hline $11 / 18-11 / 23$ & & 9.21 & 2501 & 1.7 & 45.1 & 0.51 & 14 1 & N.D. & N.D. & 45 & 1221 & N.D. & N.D. \\
\hline $1128-1201$ & & 6.51 & 175 & 0.9 & $-40 !$ & 16.7 & 4511 & N.D. & N.D. & 2.9 & 77tI & N.D. & N.D. \\
\hline $1201-1208$ & & 6.5 & 175 & 1.7 & 47.3 & 156 & 4231 & N.b. & N.D. & 7.2 & 1951 & N.D. & N.D. \\
\hline $11 / 21$ & 501 & 4.7 & 127 & 2.01 & 538 & 0.2 & 51 & N.D. & N.D. & 2.7 & 721 & N.D. & IN.D. \\
\hline $1209-12.15$ & & 6.11 & 165 & 1.01 & 276 & 9.1 & 2451 & N.D. & N.D. & 4.4 & $118 \mid$ & N.D. & IN.D. \\
\hline $12 / 16-12 \sqrt{2} 2$ & & 5.61 & 1521 & 0.9 & 230 & 15.4 & $416 !$ & N.D. & N.D. & 23 & 611 & 0.70 & 190 \\
\hline & & & 5 & & & & & & & & & & \\
\hline & & & & & & & & & & & & & \\
\hline MIN & & 1.6 & 44 & 0.41 & 109 & 0.1 & 2 & 0,37 & 10 & 23 & 61 & 0.03 & 0.8 \\
\hline MAX & & 17.5 & $\$ 740$ & 110 & 2980 & 23.7 & 6410 & 23 & 69 & 176 & 477 & 1.8 & 483 \\
\hline MEAN & & 4.9 & 1328 & 2.01 & 532 & $6.1 \mid$ & 1649 & 0.3 & 3.3.7 & 6.3 & 170 & 0.3 & 75 \\
\hline STD & & 3.4 & 91.1 & 1.7 & 459 & 6.4 & 1740 & 0.7 & 19 & 3.11 & 83 & 0.4 & 118 \\
\hline $\mathbf{N}$ & & 33 & 331 & 3.3! & 3.3 & 33 & 3.3 & 9 & 9 & 32 & 32 & 15! & I5 \\
\hline
\end{tabular}


ANNUAL SLUDGE DATA SUMMARY 1988 thru 1993

(1989-1993indudes Uranium Data)

Radionuclide data for Oak Ridge digested slüdge

Weekly integrated samples

Date from IL Lamen, Environmental Sciences Division

Data are in pCi/Kg and $\mathrm{Bq} / \mathrm{K} g$ wet wh

Note: $1 \mathrm{~K}_{\mathrm{g}}$ wet sludge is typically about 1 hiter

Note: N.D. not deteeted: Below minimum detection limit

Blant weekly areas indicate no sample

RADIONUCLIDES IN SLUDGE 1989

\begin{tabular}{|c|c|c|c|c|c|}
\hline $\begin{array}{l}\text { Date } \\
\text { Collected }\end{array}$ & WEEK & $\begin{array}{l}0-235 \\
\mathrm{BqK}\end{array}$ & $\begin{array}{c}\mathbf{U}-235 \\
\text { Pa/Kg }\end{array}$ & {$\left[\begin{array}{c}0-238 \\
\text { Bqug }\end{array}\right.$} & $\mathrm{PC} / \mathrm{Kg}$ \\
\hline $12 \sqrt{30}-0105$ & & IN.D. & N.D. & 369 & 99 \\
\hline $01 / 06-01 / 12$ & & N.D. & N.D. & $13 \mathrm{~A}$ & 361 \\
\hline $1113-01 / 19$ & & 0.4 & 11 & 24.7 & 667 \\
\hline $01 / 20-01 / 26$ & & 0.3 & 8 & 4.7 & 126 \\
\hline $01 / 27-02,02$ & 5 & 1.0 & 26 & IN.D. & IN.D. \\
\hline $2,03-02,09$ & & 1.2 & 33 & 49.7 & 1343 \\
\hline $2 / 10-02 / 16$ & & IN.D. & N.D. & 222 & 600 \\
\hline$2 \longdiv { 7 7 - 0 2 1 2 3 }$ & & 0.5 & 14 & IN.D. & N.D. \\
\hline $02 \sqrt{24}-0302$ & & 1.0 & 28 & 195 & 527 \\
\hline$0 3 \longdiv { 0 3 - 0 3 0 8 }$ & 10 & N.D. & IN.D. & 3.9 & 10 \\
\hline $03 / 10-03 / 16$ & & 1.8 & 49 & 66.4 & 1796 \\
\hline $03 / 17-03 / 23$ & & 1.3 & 34 & 20.7 & 559 \\
\hline $03 / 24-c$ & & 2.0 & 54 & 162 & 4. \\
\hline $03 / 31-0$ & & 0.8 & 22 & 250 & 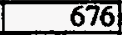 \\
\hline $04 / 07-04 / 13$ & 15 & N.D. & IN.D. & 218 & 58 \\
\hline $04 / 14-04 / 20$ & & N.D. & IN.D. & 62.3 & 1683 \\
\hline $04 / 21-04 / 27$ & & 0.8 & 21 & 391 & 105 \\
\hline $04 / 28-05,04$ & & 1.8 & 49 & 235 & 636 \\
\hline $05 / 05-05 / 11$ & & IN.D. & IN.D. & N.D. & N.D. \\
\hline $05 / 12-05 / 18$ & 20 & IN.D. & N.D. & 43 & 115 \\
\hline$5 \longdiv { 1 9 - 0 }$ & & N.D. & N.D. & 56.7 & 1532 \\
\hline$0 5 \longdiv { 2 6 - 0 6 / 0 1 }$ & & IN.D. & N.D. & 18.4 & 497 \\
\hline $06,02-0$ & & IN.D. & N.D. & 190 & 514 \\
\hline 0 & & 0.4 & 12 & 35.3 & 93 \\
\hline 22 & 25 & 2.4 & 65 & 503 & 1360 \\
\hline$3 \longdiv { 2 3 - 0 6 / 2 9 }$ & & N.D. & N.D. & 366 & 988 \\
\hline $06 / 30-07 / 06$ & & 2.0 & 55 & 255 & 68 \\
\hline$\overline{07}$ & & N.D. & IN.D. & 343 & 928 \\
\hline $07 / 14$ & & N.D. & N.D. & 510 & 1379 \\
\hline $07 / 21-6$ & 30 & 1.6 & 44 & 30.7 & 830 \\
\hline $07 / 28=$ & & 0.3 & 7 & 7.4 & 201 \\
\hline$\overline{14}$ & & 2.4 & 64 & 555 & $\overline{150}$ \\
\hline$\overline{3 / 11}$ & & 1.4 & 38 & 340 & \\
\hline$\sqrt{18-1}$ & & N.D. & N.D. & IN.D. & N.D. \\
\hline$\sqrt{25-}$ & 35 & 1.4 & 38 & N.D. & N.D. \\
\hline $0901-$ & & 2.1 & 57 & N.D. & IN.D. \\
\hline $0908-0914$ & & N.D. & N.D. & N.D. & N.D. \\
\hline $09 / 15-09 / 21$ & & N.D. & N.D. & N.D. & N.D. \\
\hline $09 / 22-1$ & & 0.4 & 12 & N.D. & N.D. \\
\hline $09 / 29-1$ & 40 & N.D. & N.D. & N.D. & IN.D. \\
\hline $106-$ & & 23 & 62 & N.D. & IN.D. \\
\hline $10 / 13-1$ & & IN.D. & N.D. & N.D. & N.D. \\
\hline & & 0.4 & 11 & 169 & $\overline{45}$ \\
\hline $27-1$ & & N.D. & IN.D. & IN.D. & N.D. \\
\hline 3 & 45. & 0.7 & 18 & 119 & $\overline{321}$ \\
\hline-1 & & IN.D. & N.D. & N.D. & N.D. \\
\hline & & 1.3 & 36 & 220 & 596 \\
\hline $4-1$ & & N.D. & N.D. & 5.1 & 139 \\
\hline $1-1$ & & N.D. & IN.D. & N.D. & N.D. \\
\hline $3-1$ & 50 & N.D. & N.D. & 4.7 & 126 \\
\hline $12 \pi$ & & N.D. & N.D. & & \\
\hline $12 \sqrt{2}$ & & IN.D. & N.D. & 405 & 1096 \\
\hline & & 0.3 & 7 & 3.9 & 105 \\
\hline & & 2.4 & 65 & 66.4 & 179 \\
\hline $\bar{M}$ & & 0.6 & 17 & 198 & 53 \\
\hline D & & 0.8 & 21 & 19.3 & 522 \\
\hline$=$ & & 26 & 26 & 36 & \\
\hline
\end{tabular}


ANNUAL SLUDGE DATA SUMMARY 1988 thru 1993

(1989-1993indudes Uranium Data)

Radionuclide data for Oak Ridge digested sludge

Weekly integrated samples

Data from li. Larsen. Environmental Sciences Division

Data are in $\mathrm{pCi} / \mathrm{Kg}$ and $\mathrm{Bq} / \mathrm{K}_{\mathrm{g}}$ wet wt.

Note: $1 \mathrm{Kg}$ wet siudge is typieally about 1 liter

Note: N.D. not detected: Below minimum detection limit

Blank weekly areas indicate no sample

RADIONUCLIDES NN SLUDGE 1989

\begin{tabular}{|c|c|c|c|c|c|c|c|c|c|c|c|c|c|}
\hline $\begin{array}{c}\text { Date } \\
\text { Collected }\end{array}$ & WEEK & $\begin{array}{l}C 0-60 \\
\text { Bqug }\end{array}$ & $\begin{array}{c}\infty 0-60 \\
\text { PG/Kg }\end{array}$ & $\mid \begin{array}{l}\mathrm{CS}-137 \\
\mathrm{BqKg}\end{array}$ & $\begin{array}{l}\mathrm{CS}-137 \\
\mathrm{PQ} / \mathrm{Kg}\end{array}$ & $\begin{array}{l}I-131 \\
\text { BquKg }\end{array}$ & $\begin{array}{l}\mathrm{I}-131 \\
\mathrm{PO} / \mathrm{Kg}\end{array}$ & $\begin{array}{l}\mathrm{BE}-7 \\
\mathrm{BgLKg}\end{array}$ & $\begin{array}{l}\mathrm{BE}-7 \\
\mathrm{PQ} / \mathrm{Kg}\end{array}$ & $\begin{array}{l}\mathrm{K}-40 \\
\mathrm{~Bq} \mathrm{Kg}_{\mathrm{g}}\end{array}$ & $\begin{array}{l}\mathrm{K}-40 \\
\mathrm{PO} / \mathrm{Kg}\end{array}$ & $\begin{array}{l}\mathrm{RA}-228 \\
\mathrm{BqUK}\end{array}$ & $\begin{array}{l}\text { RA-228 } \\
\text { POKK }\end{array}$ \\
\hline $12 \sqrt{30-0105}$ & & 5.0 & 135 & 1.0 & 27 & 16.4 & .442 & 1.4 & 39.1 & 6.6 & 179 & N.D. & N.D. \\
\hline $01 / 06-01 / 22$ & & 5.3 & 143 & 0.8 & 21 & 146 & 395 & N.D. & N.D. & 3.8 & 103 & 1.0 & 27.4 \\
\hline $01 / 13-01 / 19$ & & 4.1 & 1111 & 1.2 & 33 & 102 & 276 & 1.3 & 36.4 & 4.3 & 117 & 1.9 & 512 \\
\hline $01 / 20-01 / 26$ & & 5.4 & 146 & 0.7 & 19 & 3.6 & 97 & IN.D. & N.D. & 75 & 204 & 15 & 410 \\
\hline $01 / 27-0202$ & (3) & 4.4 & 119 & 13 & 36 & 26 & 71 & 1.6 & 443 & 4.3 & 117 & 03 & 3 \\
\hline $0205-0209$ & & 4.3 & 117 & 13 & 35 & 15 & 41 & 1.4 & 368 & 4.8 & 129 & N.D. & N.D. \\
\hline $02 / 10-02 / 16$ & & 3.6 & 96 & 1.1 & 30 & 4.6 & 125 & $\overline{0.3}$ & 14.3 & 112 & 304 & 0.7 & it \\
\hline $02 / 17-02 / 3$ & & 24 & 64 & 1.2 & 33 & 7.51 & 202 & IN.D. & N.D. & 4.6 & 123 & IN.D. & N.D. \\
\hline $02 / 24-0302$ & & 28 & 761 & 13 & 34 & 8.3 & 224 & N.D. & N.D. & 5.0 & 134 & IND. & N.D. \\
\hline $03 / 03-0308$ & 10 & 28 & 76 & 13 & 351 & 6.6 & 178 & 0.6 & 17.4 & 7.7 & 209 & 0.4 & 120 \\
\hline $03 / 10-03 / 16$ & & 109 & 294 & 1.5 & 401 & 25 & 67 & N.D. & N.D. & 5.7 & 155 & 0.3 & \\
\hline $03 / 17-03 / 23$ & & 2.7 & 72 & 1.3 & 34 & 3.2 & 83 & N.D. & N.D. & 721 & 194 & N.D. & TN.D. \\
\hline $03 / 24-03 / 30$ & & 22 & 59 & 1.3 & 36 & 6.51 & 176 & 1.7 & 455 & 9.81 & 264 & N.D. & N.D. \\
\hline $103 / 31-04,06$ & & 2.6 & 71! & 1.2 & 33 & 16.5 & 445 & IN.D. & N.D. & 9.8 & 266 & 0.9 & $\overline{23}$ \\
\hline $0407-0413$ & 15 & 5.8 & 156) & 1.0 & 281 & 199 & 538 & 0.8 & 22.4 & 8.7 & 236 & N.D. & TN.D. \\
\hline $104 / 14-04 / 20$ & & 1.8 & 48 & 0.8 & 21 & 118 & 319 & 0.6 & 162 & 6.5 & 175 & 0.4 & 108 \\
\hline $104 / 21-04 / 27$ & & 1.5 & 41 & 0.9 & 23 & 8.0 & 216 & N.D. & N.D. & 8.11 & 218 & 0.7 & 185 \\
\hline $104 / 28-05104$ & & 1.2 & 32 & 1.1 & 29 & \begin{tabular}{l|l}
5.3 \\
\end{tabular} & 142 & $3 \overline{3}$ & 886 & 6.1 & 166 & 13 & 35. \\
\hline $105 / 05-05 / 1$ & & 1.7 & 46 & 1.3 & 36 & 7.0 & 189 & IN.D. & W.D. & 8.5 & 229 & 0.2 & 4.3 \\
\hline $05 / 12=05 / 18$ & 20 & 15 & 401 & 0.8 & 22 & 9.4 & 255 & N.D & N.D. & 6.0 & 161 & 1.0 & 260 \\
\hline $05 / 19-05 / 25$ & & 1.9 & 52) & 1.2 & 32 & 7.9 & 213 & N.D. & N.D. & 16.4 & 44 & N.D. & N.D. \\
\hline $05 / 26-06 / 01$ & & 1.6 & 43 & 1.0 & 28 & 19.7 & 533 & $1 . \overline{4}$ & 375 & 5.6 & 151 & N.D. & N.D. \\
\hline $106 / 02-0608$ & & 1.6 & 44 & 0.9 & 24 & 185 & ड011 & N.D. & N.D. & 6.7 & 182 & ND. & ND. \\
\hline $06 / 09-06 / 15$ & & 2.2 & 601 & 0.9 & 23 & 162 & 438 & 0.9 & 250 & 6.9 & 187) & 1.3 & 345 \\
\hline$\longdiv { 0 6 / 1 6 - 0 6 \longdiv { 2 2 } }$ & 25 & 2.0 & 55ा & 1.0 & 28 & 111 & 301 & 0.7 & 196 & 6.8 & $184 \mid]$ & N.D. & N.D. \\
\hline$\longdiv { 0 6 / 2 3 - 0 6 / 2 9 }$ & & 1.7 & 45 & 0.91 & 25 & 5.9 & 159 & 1.6 & 445 & 3.8 & 103 & ND. & N.D. \\
\hline $06 / 30-0706$ & & 1.9 & 52 & 1.0 & 28 & 3.6 & 97 & 1.4 & 3701 & 6.8 & 183 & 1.4 & 372 \\
\hline $07 / 07-07 / 13$ & & 1.4 & 37 & 1.2 & 32 & 2.01 & $54 \mid$ & N.D. & IN.D. & 6.8 & 18.3 & N.D. & N.D. \\
\hline$\longdiv { 0 7 / 1 4 - 0 7 / 2 0 }$ & & $1.8 !$ & 48 & 1.1 & 31 & 1.6 & 42 & 3.1 & 82.7 & 3.9 & 106 & N.D. & IND. \\
\hline $07 / 21-07 / 27$ & 30 & 1.6 & 42 & 1.2 & 32 & 0.8 & 211 & 2.1 & 56.5 & 8.6 & 233 & 0.6 & 16.4 \\
\hline $107 / 28-08 / 0.3$ & & 1.8 & 501 & 1.9 & 52 & 0.7 & 191 & N.D. & N.D. & 2.0 & 541 & N.D. & N.D. \\
\hline $08 / 40-08110$ & & 1.7 & 47 & 1.0 & 28 & 1.7 & 45 & 1.2 & 322 & 5.6 & 151 & 0.5 & 146 \\
\hline $08 / 11-08 / 17$ & & 1.8 & 50 & 1.0 & 27 & 1.6 & 44 & 1.7 & 449 & 6.8 & 184 & N.D. & N.D. \\
\hline $08 / 18-08 / 24$ & & 4.6 & 123 & 1.3 & 34 & 1.4 & 391 & N.D. & N.D. & 53 & 142 & 1.1 & 29.3 \\
\hline $08.25-08.31$ & 35 & 13 & 35 & 1.1 & 31 & 1.0 & 271 & N.D. & N.D. & 3.0 & 80 & N.D. & N.D. \\
\hline $0901-09 / 07$ & & 13 & 36 & 1.0 & 27 & 11.7 & 315 & 1.4 & 370 & 4.2 & 113 & 0.7 & 193 \\
\hline $09 / 08-09 / 44$ & & 1.1 & 29 & 2.0 & 53 & 46.1 & 12461 & N.D. & N.D. & 5.6 & 152 & 03 & 83 \\
\hline $09715-09 / 21$ & & 1.1 & 30 & 1.4 & 38 & 31.7 & 857 & 0.7 & 19.4 & 63 & 170 & 1.2 & 323 \\
\hline $109 / 22-09 / 28$ & 1 & 1.41 & 39) & 1.6 & 42 & 13.1 & 3531 & N.D. & N.D. & 5.1 & 138 & 0.7 & 198 \\
\hline $109 / 29-1005$ & 40 & 13 & 36 & 13 & 36 & 128 & 34611 & N.D. & N.D. & 7.4 & 201 & 0.7 & 18.8 \\
\hline $100 x-10 \pi 2$ & & 1.9 & 52 & 1.0 & 28 & 7.1 & 1911 & N.D. & N.D. & 75 & 203 & ND. & D. \\
\hline $10 / 3-1019$ & & 1.4 & 38 & 1.6 & 43 & 4.9 & 132 & N.D. & N.D. & 15 & 41 & 0.9 & $23 \bar{A}$ \\
\hline $10 / 20-1026$ & & 1.4 & 37 & 1.2 & 33 & 3.8 & $104 \mid \frac{1}{10}$ & N.D. & N.D. & 6.4 & 172 & 0.3 & 8.2 \\
\hline $1027-1102$ & & $|3|$ & 36 & 1.0 & 26 & 3.0 & 8011 & N.D. & N.D. & 0.6 & 161 & N.D. & N.D. \\
\hline$\longdiv { 1 1 0 3 - 1 1 0 9 }$ & 45 & 1.3 & 35 & 1.7 & $46 !$ & 3.8 & $103 / 1$ & N.D. & N.D. & 6.51 & 175 & 1.6 & 432 \\
\hline $11 / 10-11 / 16$ & & 13 & 34 & 0.9 & 25) & 3.6 & $981 \mathrm{I}$ & N.D. & N.D. & 6.8 & 185 & 0.7 & 182 \\
\hline $11 / 17-11 / 23$ & & 1.1 & 30 & 1.0 & 27 & 2.7 & 7312 & N.D. & N.D. & 53 & $142 \mathrm{~s}$ & N.D. & No. \\
\hline $11 / 24-11 / 30$ & & 1.01 & 26 & 1.2 & 32 & 2.1 & 5611 & N.D. & N.D. & 7.7 & 207 & 0.2 & 42 \\
\hline $1201-1207$ & & 1.2 & 321 & 1.0 & 28 & 1.4 & 39 & 2.2 & 598 & 5.6 & 152 & 1.07 & 281 \\
\hline $12 / 08-12 / 4$ & 50 & 1.0 & 281 & 0.8 & 21 & 1.6 & $441 \Omega$ & N.D. & N.D. & 5.1 & 138 & 0.9 & 253 \\
\hline $12 / 15-12 / 21$ & & 1.2 & 32 & 1.2 & 331 & 1.0 & 271 & N.D. & N.D. & 5.6 & 15211 & N.D. & N.D. \\
\hline $12,22-12,28$ & & 0.9 & 23 & 1.01 & 28 & 0.6 & 15ा & N.D. & N.D. & 10.3 & 279 & $1.1 \mid$ & 300 \\
\hline & & & & & & & & & & & & & \\
\hline $\mathrm{MIN}$ & & 0.9 & 231 & 0.7 & 19 & 0.6 & 15 & 0.5 & 14.3 & 0.6 & 16 & 0.2 & $\overline{43}$ \\
\hline MAX & & 109 & 294 & 2.0 & 53 & 46.1 & 1246 & 33 & 886 & $16 A$ & 44| & 1.9 & 512 \\
\hline MEAN & & 23 & 6.31 & 1.2 & 31 & 7.9 & 213 & 3.4 & 390 & 631 & 171 & ost & $\frac{12}{133}$ \\
\hline STD & & 1.7 & 47 & 0.3 & 7 & 8.4 & 226 & 0.7 & 192 & 23 & 68 & ost & $14 A$ \\
\hline $\mathrm{N}=$ & & 521 & \begin{tabular}{l|l}
52 \\
\end{tabular} & 52 & 52 & 52 & 52 & 22 & 22 & 52 & 52 & 31! & 31 \\
\hline
\end{tabular}


ANNUAL SLUDGE DATA SUMMARY 1988 thru 1993

(1989-1993 includes Uranium Data)

Radionuclide data for Oak Ridge digested aludge

Weetly integrated samples

Data from If Larsen, Environmental Sciences Division

Data are in $\mathrm{pCi} / \mathrm{Kg}$ and $\mathrm{Bg} / \mathrm{Kg}$ wet wt.

Note: $1 \mathrm{Kg}$ wet sludge is typically about 1 liter

Note: N.D. not detected: Below minimum detection limit

Biant weekly areas indicate no sample

\section{RADIONUCLIDES IN SLUDGE 1990}

\begin{tabular}{|c|c|c|c|c|c|}
\hline $\begin{array}{l}\text { Date } \\
\text { Collected }\end{array}$ & WEEK & $\begin{array}{l}\mathrm{U}-235 \\
\mathrm{Bqugg}\end{array}$ & $\begin{array}{l}\text { O-235 } \\
\text { POUKg }\end{array}$ & $\begin{array}{l}\mathrm{U}-238 \\
\mathrm{BquKg}\end{array}$ & $\begin{array}{l}\text { U-238 } \\
\text { POUKg }\end{array}$ \\
\hline $12 \sqrt{30-01 / 04}$ & 1 & 0.16 & 4 & N.D. & N.D. \\
\hline $0105-01 / 11$ & & 0.48 & 13 & N.D. & N.D. \\
\hline $01 / 12-01 / 18$ & & 0.41 & 11 & 5.6 & 151 \\
\hline $01 / 19-01 / 25$ & & 0.59 & 16 & N.D. & N.D. \\
\hline $01 / 26-02 / 01$ & $\underline{5}$ & 0.59 & 16 & N.D. & N.D. \\
\hline $02 / 02-0208$ & & 0.15 & 4 & 16.1 & 436 \\
\hline $02109-02115$ & & 0.16 & 4 & N.D. & N.D. \\
\hline $02 / 16-02 / 22$ & & 0.15 & 4 & N.D. & N.D. \\
\hline $02 / 23-03 / 01$ & & 2.74 & 74 & N.D. & N.D. \\
\hline $03 / 02-03 / 08$ & 10 & 281 & 76 & N.D. & N.D. \\
\hline $03 / 09-03 / 15$ & & 0.48 & 13 & N.D. & N.D. \\
\hline $03 / 16-03 / 22$ & & 0.23 & 6) & N.D. & N.D. \\
\hline $03 / 23-0$ & & 0.18 & 5 & N.D. & N.D. \\
\hline $03 / 30-04,05$ & & 203 & 55 & 882 & 2385 \\
\hline$0 4 \longdiv { 0 6 - 0 4 / 1 2 }$ & 15 & 0.19 & 5 & N.D. & N.D. \\
\hline $04 / 13-04 / 19$ & & 0.21 & 6 & N.D. & N.D. \\
\hline $0420-0$ & & 1.81 & 49 & 49.4 & 1335 \\
\hline $04 / 27-05 / 03$ & & 1.26 & 34 & N.D. & N.D. \\
\hline $05 / 04-05 / 10$ & & 0.16 & 4 & N.D. & N.D. \\
\hline $05 / 11-0$ & 20 & 0.20 & 5 & N.D. & N.D. \\
\hline $05 / 18-05 / 24$ & & 0.19 & 5 & N.D. & N.D. \\
\hline $05 / 25-05 / 31$ & & 0.20 & 5 & 326 & 880 \\
\hline$0 6 \longdiv { 0 1 - 0 6 }$ & & 1.04 & 28 & N.D & N.D \\
\hline $06,08-06$ & & 2.15 & 58 & N.D & N.D \\
\hline $06 / 15-06$ & 25 & & & & \\
\hline $06 / 22-06 / 28$ & & 0.15 & 4 & N.D & N.D \\
\hline $06 / 29-07$ & & 0.74 & 201 & N.D & N.D \\
\hline $07106-07$ & & 059 & 16 & 6.7 & 180 \\
\hline $07 / 13-07 / 19$ & & 0.10 & 3 & N.D & N.D \\
\hline $07 / 20-07 / 26$ & 30 & 0.201 & 5 & 100 & 269 \\
\hline$\sqrt{27-08}$ & & 0.70 & 19: & 14.7 & 398 \\
\hline $303-08$ & & 0.07 & 2 & 120 & 325 \\
\hline$\sqrt[110-08]{ }$ & & 0.331 & 9 & 126 & 341 \\
\hline$\longdiv { 1 7 - 0 8 }$ & & 0.27 & 7 & 249 & 672 \\
\hline $24-08$ & 35 & & & & \\
\hline $8 / 31-09$ & & 0.63 & 17 & 160 & 433 \\
\hline $07-09 \pi 3$ & & 0.25 & 7 & N.D. & N.D. \\
\hline $114-09$ & & 188 & 508 & N.D. & N.D. \\
\hline $21-09$ & & 111 & 299 & 1.1 & 31 \\
\hline $28-1004$ & 401 & 0.44 & 12 & N.D. & N.D. \\
\hline $05-10 n 1$ & & 0.21 & 6 & N.D. & N.D. \\
\hline $2-10$ & & 1.3 & 36 & N.D. & N.D. \\
\hline $9-10 / 25$ & & 1.1 & 31 & N.D. & N.D. \\
\hline $26-1101$ & & 0.96 & 26 & 23 & 63 \\
\hline $11002-1108$ & 45 & 0.24 & 6 & N.D. & N.D. \\
\hline $09-11$ & & 0.78 & 21 & N.D. & N.D. \\
\hline $6-11$ & & 0.55 & 15 & 0.5 & 14 \\
\hline $23-11 / 29$ & & 0.09 & 2 & N.D. & N.D. \\
\hline $130-1206$ & & 0.85 & 23 & N.D. & N.D. \\
\hline $1207-12 / 23$ & 50 & 0.09 & 2 & N.D. & N.D. \\
\hline $12 / 14-12 / 21$ & & N.D. & N.D. & N.D. & N.D. \\
\hline $122-12 / 28$ & & 0.96 & 26 & N.D. & N.D. \\
\hline & & 0.07 & 21 & 0.5 & \\
\hline$\overline{A X}$ & & 188 & 508 & 882 & 2385 \\
\hline$\overline{E A N}$ & & 1.2 & 3.3 & 195 & 158 \\
\hline$\overline{\mathbf{D}}$ & & 3.0 & 81 & 222 & 408 \\
\hline & & 49 & 49 & 15! & 15 \\
\hline
\end{tabular}


ANNUAL SLUDGE DATA SUMMARY 1988 thru 1993

(1989-1993includes Uranium Data)

Radionuelide data for Oak Ridge digested shudge

Weeky integrated samples

Data from II Larsen. Environmental Sciences Division

Data are in $\mathrm{pCi} / \mathrm{Kg}$ and $\mathrm{Bq} / \mathrm{Kg}$ wet wh.

Note: $1 \mathrm{Kg}$ wet sludge is typically about 1 liter

Note: N.D. not deteeted: Below minimum detection limit

Blank weekly areas indieate no sample

RADIONUCLIDES IN SLUDGE 1990

\begin{tabular}{|c|c|c|c|c|c|c|c|c|c|c|c|c|c|}
\hline $\begin{array}{c}\text { Date } \\
\text { Collected }\end{array}$ & WEEK & $\begin{array}{l}C O-60 \\
B q / K g\end{array}$ & $\begin{array}{l}\mathrm{OO}-60 \\
\mathrm{PQ} / \mathrm{Kg}\end{array}$ & $\begin{array}{l}\mathrm{CS}-1.37 \\
\mathrm{Bg} / \mathrm{Kg}\end{array}$ & $\left.\mid \begin{array}{c}\mathrm{S}-137 \\
\mathrm{PQ} / \mathrm{Kg}\end{array}\right]$ & $\begin{array}{l}1-131 \\
\mathrm{Bg} / \mathrm{Kg}\end{array}$ & $\mid \begin{array}{l}-131 \\
\mathrm{PO} / \mathrm{Kg}\end{array}$ & {$\left[\begin{array}{l}\mathrm{Bg}-7 \\
\mathrm{Bg} / \mathrm{Kg}\end{array}\right.$} & {$\left[\begin{array}{l}\mathrm{BE}-7 \\
\mathrm{PO} / \mathrm{K}\end{array}\right.$} & $\begin{array}{l}\mathrm{K}-40 \\
\mathrm{Bg} / \mathrm{Kg}\end{array}$ & $\begin{array}{l}K-40 \\
P O / K g\end{array}$ & $\begin{array}{l}\mathrm{RA}-228 \\
\mathrm{~Bq} / \mathrm{Kg}\end{array}$ & $\begin{array}{l}\mathrm{RA}-228 \\
\mathrm{PaAR}\end{array}$ \\
\hline $12 \sqrt{30}-0104$ & 1) & 1.2 & 32 & 4.6 & 123 & 0.6 & 16 & N.D & IN.D & $9: 4$ & 254 & $\mathbf{N} . \mathrm{D}$ & $\mathbf{N D}$ \\
\hline $01105-01 / 11$ & & 1.0 & 26 & 0.6 & 16 & 0.1 & 3 & N.D & N.D & 4.4 & 118 & 1.1 & 1 \\
\hline $01 / 12-01 / 18$ & & 0.8 & 22 & 0.7 & 19 & 0.2 & 3 & 1.3 & 36.4 & 7.9 & 213 & N.D & N.D \\
\hline $01 / 19-01 / 25$ & & 0.7 & 19 & 0.9 & 24 & 1.0 & 27 & N.D & IN.D & 6.7 & 181 & 1.0 & \\
\hline $01 / 26-02 / 01$ & 5 & 0.6 & 15) & 0.7 & 18 & 5.3 & 143 & 0.6 & 16.1 & 35 & 94 & N.D & IN.D \\
\hline $0202-02108$ & & 0.6 & i7 & 0.7 & 181 & 4.6 & 124 & N.D & IN.D & 45 & 121 & 0.63 & 17 \\
\hline $02 / 09-02 / 15$ & & 0.6 & 15 & 0.3 & 91 & 3.0 & 82 & N.D & IN.D & 5.1 & 138 & 0.67 & 18 \\
\hline $02 / 16-02 / 22$ & & 0.4 & 11 & 0.7 & 20 & 1.6 & 42 & 0.3 & 8.5 & 5.8 & 156 & 0.85 & 23 \\
\hline $02 / 23-03 / 01$ & & 0.7 & 18 & 1.1 & 31 & 1.0 & 26 & 22 & 389 & 4.9 & 133 & 2.0 & 53 \\
\hline $03,02-0308$ & 10 & 0.7 & 19 & 1.2 & 32 & 4.8 & 130 & 3.2 & 868 & 9.2 & 250 & 2.0 & 54 \\
\hline $03 / 09-03 / 15$ & & 0.6 & 17 & 1.1 & 30 & 8.5 & 230 & 1.1 & 290 & 7.0 & 188 & 0.85 & 23 \\
\hline $03 / 16-03 / 22$ & & 0.9 & 25 & 1.0 & 28 & 110 & 298 & N.D & N.D & 100 & 270 & 23 & 62 \\
\hline $03 / 23-03 / 29$ & . & 0.9 & 25 & 0.9 & 24 & 5.4 & 146 & N.D & N.D & 100 & 270 & 25 & 67 \\
\hline $03 / 30-04,05$ & & 2.1 & 58 & 0.7 & 19 & 3.5 & 94 & 1.3 & 361 & 8.7 & 236 & 28 & 75 \\
\hline $04 / 06-04 / 12$ & 15 & 2.8 & 75 & 0.7 & 18 & 2.1 & 57 & N.D & ND & 111 & 301 & 0.75 & 20 \\
\hline $04 / 1.3-04 / 19$ & & 5.51 & 150 & 1.6 & 43 & 1.0 & 26 & N.D & IN.D & 45 & 122 & 2.6 & 72 \\
\hline $04 / 20-04 / 26$ & & 8.01 & 217 & 0.7 & 20 & 1.3 & 35 & N.D & N.D & 4.2 & 114 & 1.5 & 40 \\
\hline $04 / 27-05 / 03$ & & 8.81 & 239 & 0.9 & 24 & 0.8 & 22 & N.D & N.D & 6.9 & 186 & 1.1 & 30 \\
\hline $05 / 04-05 \pi 0$ & & 7.4 & 199 & 0.6 & 15 & 0.6 & 17] & N.D & N.D & 7.1 & 191 & 23 & 63 \\
\hline $05 / 11-05 / 17$ & 201 & 9.0 & 243 & 1.0 & 27 & 1.0 & 26 & 2.6 & 71.4 & 7.6 & 206 & 231 & 68 \\
\hline $05 / 18-05 / 24$ & & 108 & 292 & 0.8 & 21 & 0.3 & 7 & N.D & N.D & 6.8 & 185 & ND & IN.D \\
\hline $0525-0531$ & & 3.8 & 104 & 2.0 & 54 & 0.3 & 7 & N.D & IN.D & 131 & 354 & 3.01 & 82 \\
\hline $06101-0607$ & & 4.8 & 130 & 0.8 & 22 & 0.1 & 4 & N.D & N.D & 7.5 & 202 & 0.92 & 25 \\
\hline $06 / 08-06 / 14$ & & 5.4 & 145 & 1.0 & 27 & 0.1 & 3 & N.D & N.D & 4.7 & 128 & ND & IN.D \\
\hline $06 / 15-06 / 21$ & 251 & & & & & & & & & & & & \\
\hline $06 / 22-06 / 28$ & & 5.01 & 136 & 0.9 & 24 & 0.1 & 3 & 3.7 & 99.7 & 851 & 230 & 1.6 & 42 \\
\hline $06 / 29-07,05$ & & 4.3 & 117 & 0.9 & 241 & 0.1 & 2 & 3.2 & 86.4 & 10.7 & 290 & 12 & 33 \\
\hline $07106-07112$ & & 3.7 & 99 & 1.9 & 521 & 1.2 & 31 & 1.1) & 28.7 & 75 & 202 & 0.551 & 15 \\
\hline $07 / 13-07 / 19$ & & 3.0 & 821 & 0.7 & 19 & 25 & 67 & N.D & N.D & 8.4 & 228 & 1.0 & 26 \\
\hline $07 / 20-07 / 26$ & 30 & 23 & 63 & 0.6 & 16 & 166 & 448 & 1.3 & 358 & 5.0 & 136 & 0.48 & 13 \\
\hline $07 / 27-0802$ & & 3.2 & 86 & 0.6 & 16 & 153 & 413 & 23 & 613 & 751 & 204 & 0.18 & \\
\hline $08,03-08,09$ & & 231 & 62 & 0.6 & 17 & 300 & 811 & 0.9 & 24.4 & 6.4 & 174 & 0.49 & 13 \\
\hline $08 / 10-0816$ & & 231 & 6.3 & 0.7 & 19 & 161 & 435 & 1.7 & 45.1 & 6.4 & 172 & 0.83 & 23 \\
\hline $0907-09 \pi 3$ & & 1.4 & 37! & 0.7 & 20 & 6.7 & 181 & 1.4 & 390 & 7.4 & 199 & 0.68 & 18 \\
\hline $09 / 14-09 / 20$ & & 1.6 & 42 & 1.8 & 48 & 6.5 & 175 & 25 & 686 & 7.7 & 207 & 0,59 & 16 \\
\hline $09 / 21-09 / 27$ & & 2.6 & 69 & 1.7 & 46 & 1.81 & 49 & N.D & N.D & 8.4 & 226 & 0.89 & 24 \\
\hline $09 / 28-10 / 04$ & 401 & 4.6 & 124 & 7.3 & 196 & 15 & 41 & 1.3 & 340 & 5.8 & 158 & 1.0 & 26 \\
\hline $10 / 05-10111$ & & 4.6 & 124 & 9.2 & 249 & 0.9 & 23 & 1.1 & 298 & 3.4 & 91 & 0.48 & 13 \\
\hline $10 / 12-10 / 18$ & & 5.3 & 143 & 15.4 & 415 & 1.1 & 29 & 1.1 & 30.5 & 9.0 & 244 & 1.4 & 39 \\
\hline $10 / 19-10 / 25$ & & 251 & 67 & 73 & 198 & 1.0 & 281 & 1.5 & 416 & 4.8 & 129 & 0.59 & 16 \\
\hline $10 / 26-1101$ & & 3.9 & 106 & 11.5 & 310 & 2.2 & 601 & N.D & N.D & 5.5 & 148 & 0.78 & 21 \\
\hline $1102-1108$ & 45 & 3.2 & 87 & 9.6 & 260 & 4.2 & $114 !$ & N.D & N.D & 55 & 148 & 0.26 & \\
\hline $1109-11 / 25$ & & 2.4 & 64 & 6.7 & 182 & 2.6 & 70 & 1.0 & 270 & 45 & 121 & 0.33 & \\
\hline $11 / 16-11 / 22$ & & 1.8 & 48 & 4.5 & 121 & 1.4 & 37 & 1.2 & 336 & 2.7 & 74 & 0.49 & 13 \\
\hline $11 / 23-11 / 29$ & & 1.3 & 36 & 3.0 & 82 & 252 & 682 & 1.3 & 359 & 4.6 & 125 & 0.57 & 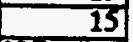 \\
\hline $11,30-1206$ & & 2.0 & 54 & 4.8 & 131 & 25.1 & 6781 & N.D & N.D & 3.0 & 81 & N.D & $\mathbf{N . D}$ \\
\hline $12,07-12 \sqrt{3}$ & 50 & 1.1 & 311 & 2.1 & 58 & 27.7 & 7491 & 1.0 & 27.1 & 3.5 & 94 & 0.43 & 12 \\
\hline $12 / 14-12 / 21$ & & 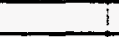 & & & & & & & & & & & \\
\hline $12 / 22-12 / 28$ & & N.D & N.D & N.D & N.D & N.D & N.D & 1.1 & 304 & 4.5 & 121 & 0.63 & 17 \\
\hline & & & & & & & & & & & & & \\
\hline $\mathrm{MUN}$ & & 0.4 & 11 & 0.3 & 9 & 0.10 & 2 & 0.3 & 85 & 27 & 74 & 0.18 & 3 \\
\hline MAX & & 108 & 292 & 15.4 & 415 & 3001 & 811 & 3.7 & 99.7 & 13.1 & 354 & 3.0 & 82 \\
\hline MEAN & & 3.0 & 81 & 2.4 & 66 & 5.3 & 145 & 0.9 & 248 & 6.6 & 179 & 1.0 & 27 \\
\hline STD & & 25 & 67 & 3.3 & 881 & 7.7 & 208 & 1.0 & 270 & 23 & 62 & 0.80 & 22 \\
\hline $\mathrm{N}=$ & & 48 & 481 & 48 & 481 & 48 & 481 & 28 & 28 & 49 & 49 & 43 & 43 \\
\hline
\end{tabular}


ANNUALSLUDGEDATA SUMMARY 1988 thru 1993

(1989-1993ipcludes Uranium Data)

Radionuclide data for Oak Ridge digested sludge

Weekly integrated samples

Data from I. L Lrsen. Environmental Sciences Division

Data are in pCi/Kg and $\mathrm{Ba} / \mathrm{Kg}$ wet $\mathrm{m}$.

Note: $1 \mathrm{~K}_{\mathrm{g}}$ wet sludge is typically about 1 liter

Note: N.D. not detected: Below minimum detection limit

Biant weekly aress indicate no sample

\section{RADIONUCIIDES IN SLUTGE 1991}

\begin{tabular}{|c|c|c|c|c|c|}
\hline $\begin{array}{l}\text { Date } \\
\text { Collected }\end{array}$ & WEEK & $\begin{array}{l}0-235 \\
\text { BglKg }\end{array}$ & $\begin{array}{l}\mathrm{U}-235 \\
\mathrm{POUK}\end{array}$ & $\mid \begin{array}{l}0-238 \\
\text { BalKg }\end{array}$ & $\begin{array}{l}0-238 \\
20148\end{array}$ \\
\hline $1228-0103$ & 1 & 0.11 & 3.1 & 211 & 5 \\
\hline $01 / 04-01 / 10$ & & 1.00 & 270 & 102 & \\
\hline $01 / 11-01 / 17$ & & 0.74 & 200 & 19.7 & \\
\hline \multicolumn{6}{|l|}{$01 / 18-01 / 24$} \\
\hline $01 / 25-01 / 31$ & 5 & 0.67 & 180 & 8.4 & 226 \\
\hline $0201-0207$ & & 0.34 & 9.2 & 6.1 & \\
\hline $02108-0214$ & & 0.33 & 9.0 & 4.1 & \\
\hline \multicolumn{6}{|l|}{$02 / 15-02 / 21$} \\
\hline $02 \sqrt{22}-02 \sqrt{28}$ & & 0.15 & 4.0 & 12 & \\
\hline $0301-0307$ & 10 & 0.59 & 16.0 & 6.4 & \\
\hline $03,08-03 / 14$ & & 0.81 & 220 & 10.1 & \\
\hline $03 / 15-03 / 21$ & & 0.36 & 9.8 & 102 & \\
\hline $03 / 22-03 / 28$ & & 052 & 140 & N.D. & N.D. \\
\hline $03 / 29-04 / 04$ & & 0.27 & 73 & 8.0 & 215 \\
\hline $04 / 05-04 / 11$ & 15 & $0 . \overline{12}$ & 3.3 & N.D. & N.D. \\
\hline $04 / 12-04 / 18$ & & 1.00 & 270 & 11.4 & 309 \\
\hline $04 / 19-4 / 25$ & & 0,52 & 140 & 126 & \\
\hline $04 / 26-05102$ & & 0.41 & 110 & N.D & N.D \\
\hline $05 / 03-05109$ & & 0.81 & 220 & 102 & 276 \\
\hline $05 / 10-05 / 16$ & 20 & 0.44 & 120 & 118 & 318 \\
\hline $05 / 17-05 / 23$ & & 0.18 & 4.9 & 0.3 & 8 \\
\hline $105 / 24-05130$ & & 0.07 & 2.0 & 125 & 338 \\
\hline $05 / 31-06 / 06$ & & 0.41 & 110 & 7.1 & 191 \\
\hline $06 / 07-06 / 13$ & & N.D. & N.D. & 1.0 & 0 \\
\hline \multicolumn{6}{|l|}{$06 / 14-06 / 20$} \\
\hline $06 \Omega 1-06 \Omega 7$ & & 0.57 & 155 & 166 & 448 \\
\hline $06 / 28-07 / 04$ & & 0.24 & 6.4 & 4.8 & 1.30 \\
\hline $07 / 05-07 / 1$ & & 0.63 & 170 & 1.9 & 51 \\
\hline $07 / 12-07 / 18$ & & 0.31 & 8.3 & 16.6 & 450 \\
\hline $07 / 19-07 / 25$ & 30 & 0.63 & 170 & 152 & 412 \\
\hline $07 / 26-0801$ & & 0.51 & 139 & 179 & 483 \\
\hline $08 / 02-08108$ & & 0.54 & 146 & 5.8 & 157 \\
\hline $08 / 09-08 \pi 5$ & & 0.23 & 6.3 & 7.4 & 201 \\
\hline $08 / 16-08 / 22$ & & 0.71 & 191 & 20.5 & 554 \\
\hline $08 / 22-08 / 29$ & 35 & 0.51 & 139 & 0.6 & 15 \\
\hline $08 / 30-0905$ & & 0.67 & 182 & 15.1 & 407 \\
\hline $9 / 06-09 / 12$ & & 0.55 & 149 & 751 & 202 \\
\hline $09 / 13-09 / 29$ & & 0.95 & 258 & 166 & 449 \\
\hline $09 / 20-09 / 26$ & & 0.43 & 116 & 7.51 & 202 \\
\hline $09 / 27-10 / 03$ & $40 !$ & 0.99 & 2681 & 229 & 618 \\
\hline $10 / 04-10 / 10$ & & 0.51 & 139 & 10.5 & 285 \\
\hline $10 / 11-10 / 17$ & & 0.53 & 14.3 & N.D. & N.D. \\
\hline $10 / 18-10 / 24$ & & 0.65 & 17.7 & N.D. & N.D. \\
\hline $10 / 25-10 / 31$ & & 0.31 & 8.31 & N.D. & N.D. \\
\hline $11101-1107$ & 45) & 0.35 & 9.41 & 5.8 & 158 \\
\hline $11 / 08-11 / 14$ & & N.D. & N.D. & 6.8 & 184 \\
\hline $11 / 15-11 / 21$ & & 0.33 & 8.9 & 5.2 & 140 \\
\hline \multicolumn{6}{|l|}{$11 / 22-11 / 28$} \\
\hline \multicolumn{6}{|l|}{$11 / 29-12,05$} \\
\hline $12 / 06-12 / 12$ & 501 & 0.53 & 142 & 6.8 & 183 \\
\hline $12 \sqrt{13}-12 \pi 9$ & & 0.59 & 16.1 & 12.3 & 332 \\
\hline $12 / 20-12 / 26$ & & & & 73 & 196 \\
\hline MEN & & 0.07 & 2.0 & 0.31 & 8 \\
\hline MAX & & 1.00 & 270 & 229 & 618 \\
\hline MEAN & & 0.49 & 123 & 9.6 & 259 \\
\hline STD & & 0.25 & 6.7 & 6.01 & 161 \\
\hline $\mathbf{N}$ & & 45 & 45 & 41 & 41 \\
\hline
\end{tabular}




\title{
ANNUALSLUDGEDATA SUMMARY 1988 thru 1993
}

(1989-1993includes Uranjum Data)

\begin{abstract}
Radionuclide data for Oak Ridge digested sludge
Weekly integrated samples

Data from IL Larsen, Environmental Sciences Division

Data are in $\mathrm{pCi} / \mathrm{K}_{\mathrm{g}}$ and $\mathrm{Bq} / \mathrm{K}_{\mathrm{g}}$ wet wh.

Note: $1 \mathrm{Kg}$ wet sludge is typieally about 1 liter

Note: N.D. not detected: Below minimum detection limit

Blank weekly areas indicate no sample
\end{abstract}

RADIONUCLIDES IN SLUDGE 1991

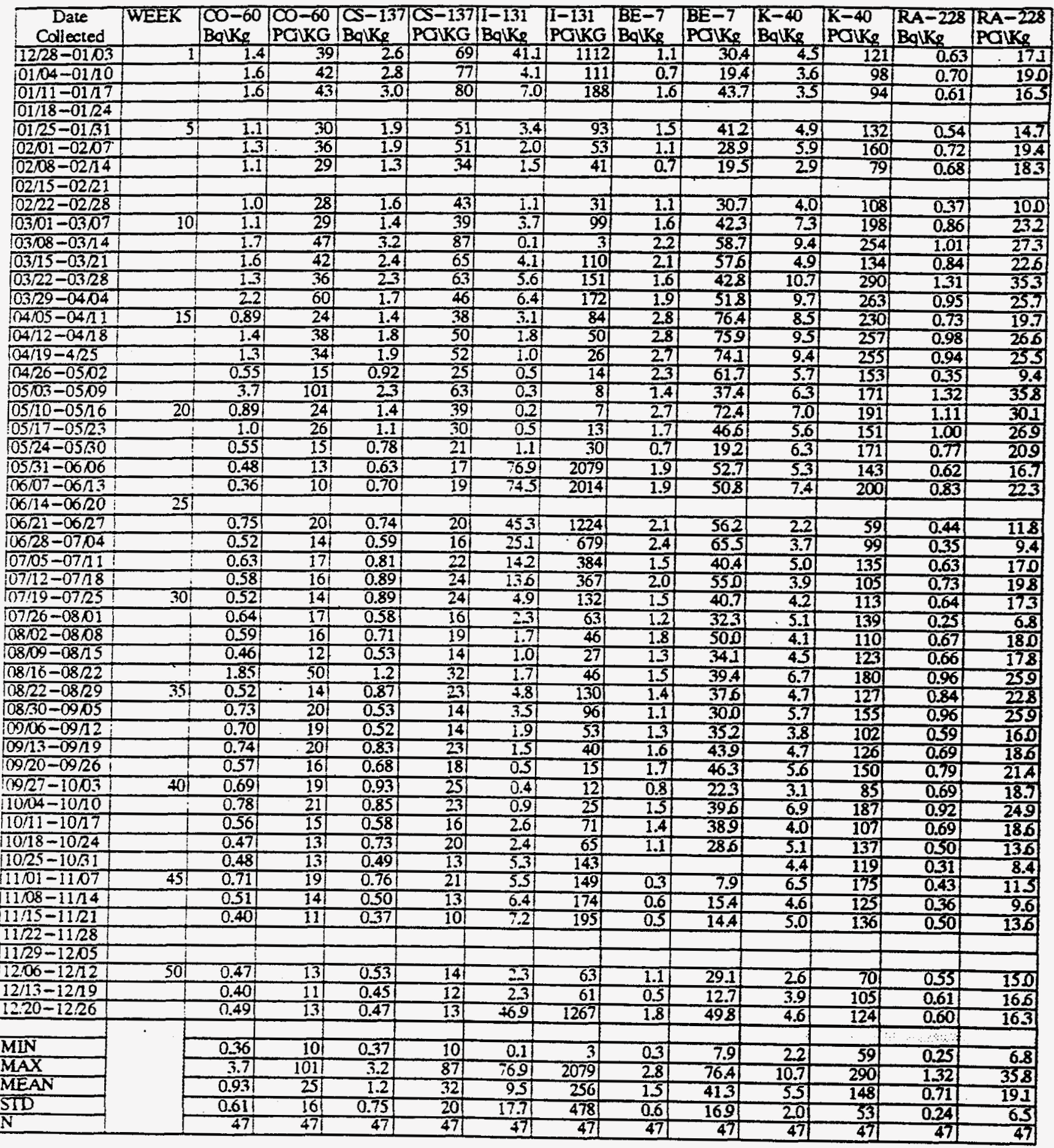


ANNUAL SLUDGE DATA SUMMARY 1988 thru 1993

(1989-1993includes Uranium Data)

Radionuclide data for Oał Ridge digested sludge

Wectly integrated samples

Data from IL Larsen, Environmental Sciences Division

Data are in $\mathrm{pCi} / \mathrm{K}_{\mathrm{g}}$ and $\mathrm{Bq} / \mathrm{K}_{\mathrm{g}}$ wet $\mathrm{m}$.

Note: $1 \mathrm{~K}_{\mathrm{g}}$ wet sludge is typically about 1 liter

Note: N.D. not detected: Below minimum detection limit

Blank weeljy areas indicate no sample

\section{RADIONUCLIDES IN SLUDGE 1992}

\begin{tabular}{|c|c|c|c|c|c|}
\hline $\begin{array}{c}\text { Date } \\
\text { Collected }\end{array}$ & WEEK & $\begin{array}{l}\mathrm{U}-235 \\
\mathrm{Bg} / \mathrm{Kg}\end{array}$ & $\begin{array}{l}0-235 \\
\text { palkg }\end{array}$ & $\begin{array}{l}U-238 \\
\text { BolKe }\end{array}$ & $\mid \begin{array}{l}0-238 \\
\text { Pakg }\end{array}$ \\
\hline $12 \sqrt{27}-0102$ & 1 & 0.8 & 20.5 & 171 & 461 \\
\hline $01103-0109$ & & 0.4 & 114 & 12.7 & 344 \\
\hline \multicolumn{6}{|l|}{$01 / 10-01 / 16$} \\
\hline $01 / 17-01 / 23$ & & 0.6 & 15.7 & 14.4 & 388 \\
\hline $01 / 24-01 / 30$ & 5 & 0.9 & 239 & N.D & N.D \\
\hline $01 \sqrt{31-0206}$ & & 1.0 & 266 & IN.D & N.D \\
\hline $02 \sqrt{07-0213}$ & & 0.5 & 128 & N.D & ND \\
\hline $02 / 14-02 / 20$ & & IN.D & N.D & N.D & N.D \\
\hline $02 \sqrt{21-02 / 27}$ & & 0.51 & 146 & 13.1 & 354 \\
\hline $02 \sqrt{28-03,05}$ & 10 & 0.3 & 8.6 & 6.0 & 161 \\
\hline $03 / 06-03 / 12$ & & 0.2 & 5.0 & 9.6 & 260 \\
\hline $03 / 13-03 / 19$ & & 0.6 & 17.4 & 6.6 & 179 \\
\hline $03 / 20-03 / 26$ & & 0.1 & 2.4 & N.D & N.D \\
\hline $03 \sqrt{27-04 / 02}$ & & 0.5 & 14.31 & 158 & 428 \\
\hline $04 / 03-0409$ & 15 & 0.7 & 186 & 72 & 194 \\
\hline $04 / 10-04 / 16$ & & 0.5 & 125 & 83 & 224 \\
\hline $04 / 17-04 / 23$ & & 0.51 & 13.1 & 176 & 475 \\
\hline \multicolumn{6}{|l|}{$04 \sqrt{24-04 / 30}$} \\
\hline $05101-05 / 07$ & & 0.9 & 24.7 & 136 & 368 \\
\hline $05 / 08-05 / 14$ & 20 & 0.2 & 5.8 & 10.7 & 290 \\
\hline $05 / 15-05 / 21$ & & 0.6 & 16.7 & 106 & 287 \\
\hline $05 / 22-05 / 28$ & & 0.8 & 210 & 169 & 456 \\
\hline \multicolumn{6}{|l|}{$05 / 29-06 / 04$} \\
\hline $06 / 05-06 / 21$ & & 0.4 & 10.7 & 9.7 & 262 \\
\hline \multicolumn{6}{|l|}{$06 / 12-06 / 18$} \\
\hline $06 / 19-06 / 25$ & & 0.3 & 8.91 & 8.1 & 220 \\
\hline $06 / 26-07 / 02$ & & IN.D & N.D & 148 & 401 \\
\hline $07103-0709$ & & N.D & N.D & N.D & N.D \\
\hline $07 / 10-07 / 16$ & & 0.5 & 130 & 235 & 635 \\
\hline $07 / 17-07 / 23$ & 30 & & & 260 & 703 \\
\hline $07 / 24-07 / 30$ & & 0.51 & 13.1 & 9.2 & 248 \\
\hline \multicolumn{6}{|l|}{$07 / 31-08,06$} \\
\hline $07107-07 / 13$ & & 0.7 & 202 & 8.9 & 240 \\
\hline $08 / 14-08 / 20$ & & 0.11 & 3.9 & 5.1 & 138 \\
\hline $08 / 21-08 / 27$ & 35 & 1.3 & 35.1 & 115 & 312 \\
\hline $08 / 28-09 / 03$ & & 0.5 & 145 & 122 & 329 \\
\hline $09 / 04-09 / 10$ & & 0.6 & 165 & 12.7 & 342 \\
\hline \multicolumn{6}{|l|}{$09 / 11-09 / 17$} \\
\hline \multicolumn{6}{|l|}{$09 / 18-09 / 24$} \\
\hline $09 / 25-1001$ & 40 & 1.4 & 388 & 179 & 485 \\
\hline $10 / 02-1008$ & & 0.8 & 20.7 & 3.6 & 98 \\
\hline $10 / 09-10 / 15$ & & N.D & N.D & 0.7 & 20 \\
\hline $10 / 16-10 / 22$ & & 1.6 & 422 & 110 & 296 \\
\hline $10 / 23-10 / 29$ & & 0.7 & 185 & 4.6 & 123 \\
\hline $10 / 30-1105$ & 45 & & & & \\
\hline $11 / 06-11 / 12$ & & 0.4 & 9.6 & N.D & N.D \\
\hline $11 / 13-11 / 19$ & & 0.9 & 24.4 & 10ड्ड & 284 \\
\hline $11 / 20-11 / 26$ & & 0.81 & 226 & 118 & 318 \\
\hline $11 / 27-1203$ & & 0.4 & 9.5 & 1.5 & 41 \\
\hline $12 / 04-12 / 10$ & 50 & 0.8 & 21.4 & 6.7 & 182 \\
\hline $12 / 11-12 / 17$ & & 0.8 & 2261 & 1.3 & 36 \\
\hline \multicolumn{6}{|l|}{$12 / 18-12 / 24$} \\
\hline \multicolumn{6}{|l|}{$12 / 25-12 / 31$} \\
\hline & & & & & \\
\hline MIN & & 0.11 & 24 & 0.7 & 20 \\
\hline MAX & & 1.6 & 422 & 260 & 703 \\
\hline MEAN & & 0.61 & 172 & 109 & 294 \\
\hline STD & & 0.3 & 8.81 & 5.61 & 152 \\
\hline $\mathbf{N}=$ & & 38 & 38 & 36 & 36 \\
\hline
\end{tabular}




\section{ANNUAL SLUDGE DATA SUMMARY 1988 thru 1993}

(1989-1993 include: Uranium Data)

Radionuclide data for Oak Ridge digested sludge

Weekly integrated samples

Data from II Larsen, Environmental Sciences Division

Data are in $\mathrm{pCi} / \mathrm{Kg}$ and $\mathrm{Bq} / \mathrm{Kg}$ wet wh

Note: $1 \mathrm{Kg}$ wet sludge is typically sbout 1 liter

Note: N.D. not detected: Below minimum detection limit

Blank weekly areas indieate no sample

RADIONUCLIDES DN SLUDGE 1992

\begin{tabular}{|c|c|c|c|c|c|c|c|c|c|c|c|c|c|}
\hline $\begin{array}{c}\text { Date } \\
\text { Collected }\end{array}$ & WEEK & $\mid$\begin{tabular}{l|}
$C 0-60$ \\
$\mathrm{BglKg}$
\end{tabular} & $\begin{array}{l}C 0-60 \\
\text { PQKg }\end{array}$ & $\begin{array}{l}\mathrm{S}-137 \\
\mathrm{~Bq} \mathrm{Kg}\end{array}$ & $\mid \begin{array}{c}\mathrm{S}-137 \\
\mathrm{PCUKg}\end{array}$ & $\begin{array}{l}1-1.31 \\
\text { BquKg } \\
\end{array}$ & $\begin{array}{l}1-131 \\
\text { PGUKg }\end{array}$ & $\begin{array}{l}\mathrm{BE}-7 \\
\text { BqlKg }\end{array}$ & $\mid \begin{array}{l}\mathrm{BE}-7 \\
\text { PGuKg }\end{array}$ & $\begin{array}{l}K-40 \\
\text { Bqugg }\end{array}$ & \begin{tabular}{l|}
$\mathrm{K}-40$ \\
POUKg
\end{tabular} & $\begin{array}{l}\text { RA-228 } \\
\text { BquK }\end{array}$ & $\begin{array}{l}\text { RA-228 } \\
\text { POUKg }\end{array}$ \\
\hline $12 / 27-0102$ & 1 & 0.58 & 158 & 0.63 & 17.1 & 4.3 .1 & 1166 & 0.6 & 16.7 & 55 & 150 & 0.59 & 159 \\
\hline $01 / 03-0109$ & & 0.68 & 18.4 & 0.53 & 142 & 38.3 & 1036 & 1.2 & 32.1 & 6.1 & 165 & 0.60 & 16.3 \\
\hline \multicolumn{14}{|l|}{\begin{tabular}{|l|}
$01 / 10-01 / 16$ \\
\end{tabular}} \\
\hline $01 / 17-01 / 23$ & & 0.63 & 169 & 0.58 & 15.7 & 200 & 540 & 1.6 & 432 & 7.9 & 214 & 0.78 & \\
\hline $01 / 24-0130$ & 5 & 0.56 & 152 & 0.45 & 121 & 12.1 & 326 & 1.1 & 308 & 6.2 & 168 & 0.81 & 221 \\
\hline $01 / 31-02 / 06$ & & 0.57 & 15.4 & 0.57 & 15.4 & 9.0 & 244 & 1.1 & 296 & 6.4 & 172 & 0.91 & 246 \\
\hline $0207-02 / 13$ & & 0.96 & 260 & 0.55 & $150 \mid$ & 14.7 & 398 & 0.9 & 24.3 & 6.4 & 172 & 0.77 & 209 \\
\hline $02 / 14-02,20$ & & 0.48 & 130 & 0.61 & 165 & 140 & 378 & N.D. & IN.D. & 7.9 & 213 & 0.53 & 142 \\
\hline $02 / 21-02 / 27$ & & 0.66 & 179 & 0.76 & 206 & 4.5 & 122 & 0.6 & 16.7 & 5.8 & 156 & 0.78 & 210 \\
\hline $02 / 28-03,05$ & 10 & 0.24 & 6.61 & 0.22 & 6.0 & 4.2 & 114 & 1.1 & 291 & 5.3 & 142 & 0.49 & 13.3 \\
\hline $03106-03 / 12$ & & 0.331 & 8.9 & 0.25 & 6.7 & 2.3 & 63 & N.D. & N.D. & 5.1 & 139 & 0.35 & 9.5 \\
\hline $03 / 13-03 / 19$ & & 0.28 & 7.6 & 0.23 & 6.2 & 1.4 & 37 & 1.1 & 292 & 4.5 & 121 & 0.23 & 0. \\
\hline $03 / 20-03 / 26$ & & 0.301 & 8.2 & 0.26 & 7.0 & 1.3 & 35 & 0.7 & 196 & 3.3 & 90 & 0.25 & 6.7 \\
\hline $03 / 27-0402$ & & 0.33 & 8.91 & 0.42 & 11.4 & 2.5 & 691 & 15 & 39.3 & 5.0 & 134 & 037 & 100 \\
\hline $0403-0409$ & 15 & 0.31 & 8.4 & 0.32 & 8.7 & 1.9 & 51 & 15 & 412 & 6.4 & 174 & 0.67 & 182 \\
\hline $04 / 10-04 / 16$ & & 0.29 & 7.9 & 0.28 & 7.6 & 13 & 34 & 1.4 & 370 & 6.0 & 162 & 0.84 & 22.7 \\
\hline $04 / 17-04 / 23$ & & 0.26 & 7.1 & 0.22 & 6.0 & 0.5 & 15 & I.1 & 299 & 4.3 & 117 & 0.60 & 163 \\
\hline \multicolumn{14}{|l|}{$04 / 24-04 / 30$} \\
\hline $105 / 01-0507$ & & 0.34 & 9.1 & 0.31 & 8.4 & N.D. & N.D. & 0.9 & 233 & 53 & 144 & 0.70 & 189 \\
\hline $105108-05 / 4$ & 20 & 0.36 & 9.8 & 0.33 & 8.9 & N.D. & N.D. & 1.6 & 42.7 & 5.0 & 134 & 0.49 & $13:$ \\
\hline $05 / 15-05 / 21$ & & 0.54 & 14.7 & 0.42 & 11.4 & N.D. & N.D. & 13 & 348 & 5.8 & 156 & 0.58 & 158 \\
\hline $05 / 22-05 / 28$ & & 0.37 & 100 & 0.31 & 8.51 & 0.21 & 6 & 1.1 & 303 & 43 & 117 & 0.85 & 231 \\
\hline \multicolumn{14}{|l|}{$05 / 29-06,04$} \\
\hline $10605-06 / 11$ & & 0.24 & 6.4 & 0.36 & 9.6 & 105 & 284 & 1.4 & 370 & 5.3 & 143 & 0.63 & 171 \\
\hline $06 / 12-06 / 18$ & 25 & & & & & & & & & & & & \\
\hline $06 / 19-06 / 25$ & & 0.30 & 8.0 & 0.29 & 7.8 & 5.1 & 137 & 1.2 & 33.4 & 3.0 & 81 & 0.01 & 0.4 \\
\hline $06 / 26-07,02$ & & 0.19 & 5.1 & 0.23 & 6.1 & 280 & 756 & 1.1 & 302 & 3.8 & 1041 & N.D. & N.D. \\
\hline $.07103-0709$ & & 0.28 & 7.7 & 0.23 & 6.11 & 708 & 1913 & 1.2 & 313 & 29 & 771 & N.D. & N.D. \\
\hline $07 / 10-07 / 16$ & & 1.63 & 4401 & 0.41 & 110 & 406 & 1097 & 1.2 & 330 & 3.3 & 90 & 1.81 & 490 \\
\hline $07 / 17-07 / 23$ & 30 & 0.46 & 12.5 & 0.41 & 112 & 2001 & 541! & 12 & 33.6 & 2.8 & $76 ! 1$ & N.D. & N.D. \\
\hline $07 / 24-07 / 30$ & & 0.34 & 9.1 & 0.36 & 9.8 & 136 & 368 & 0.6 & 16.3 & 4.3 & 116 & 0.65 & 17.7 \\
\hline \multicolumn{14}{|l|}{$07 / .51-0806$} \\
\hline 07/07-07/33 & & 0.41 & 110 & 0.44 & 120 & 46.61 & 1260 & 13 & 346 & 4.1 & 112 & 0.90 & $24 A$ \\
\hline $108 / 14-0820$ & & 0.25 & 6.8 & 0.23 & 6.2 & 14.4 & 390 & 1.0 & 276 & 2.4 & 64 & 0.41 & 110 \\
\hline $108 \sqrt{21-08 / 27}$ & 35 & 0.90 & 24.3 & 0.80 & 21.5 & 798 & 2156 & 1.6 & 44.1 & 4.11 & 111 & 0.83 & 224 \\
\hline$\longdiv { 0 8 1 2 8 - 0 9 0 3 }$ & & 1.15 & 312 & 0.60 & 162 & 396 & 1070 & 1.0 & 282 & 4.7 & 127 & 1.21 & 328 \\
\hline $09 / 04-09 / 10$ & & 1.38 & 37.4 & 0.49 & 1.3 .3 & 44.7 & 1207 & 1.8 & 479 & 5.4 & 147 & 0.68 & 183 \\
\hline \multicolumn{14}{|l|}{$09 / 11-09 / 77$} \\
\hline $09 / 18-09 / 24$ & & N.D. & N.D. & N.D. & N.D. & N.D. & N.D. & 1.9 & 50.3 & 4.1 & 111 & 0.79 & 213 \\
\hline $09 / 25-1001$ & 401 & 1.98 & 53.5 & 0.56 & 152 & 128 & 345 & 1.21 & 31.4 & 3.3 & 89 & 0.70 & 190 \\
\hline $10 / 02-1008$ & & 1.50 & 406 & 0.41 & 112 & 6.3 & 169 & 1.8 & 48.7 & 3.0 & 82 & 0351 & 150 \\
\hline $10 / 09-10 / 15$ & & 2311 & 62.4 & 1.13 & 30.61 & 2.81 & 76 & 0.8 & 216 & 5.4 & 145 & 1.25 & 339 \\
\hline $10 / 16-10 / 22$ & & 1.82 & 49.1 & 0.46 & 12.4 & 3.2 & 87 & 1.1 & 28.4 & 4.7 & 126 & 0.63 & 17. \\
\hline $10 / 23-10 / 29$ & & 1.47 & 398 & 0.61 & 165 & 3.2 & 88 & 0.8 & 211 & 4.1 & 111 & 0.49 & 132 \\
\hline $10 \sqrt{30-1105}$ & 45 & & & & & & & & & & & & \\
\hline $11 / 06-11 / 12$ & & 1.14 & 308 & 0.94 & 25.51 & 5.3 & 142! & 13 & 35.4 & 3.1 & 83 & 0.46 & 12. \\
\hline $11 / 13-11 / 19$ & & 1.21 & 326 & 0.71 & 19.11 & 4.7 & 127 & 1.6 & 442 & 4.0 & 107 & 0.58 & I5! \\
\hline $11 / 20-11 / 26$ & & $1.19 !$ & 32.11 & 0.71 & 19.3 & 3.5 & 95 & 1.4 & 38.61 & 6.1 & 165 & 0.77 & 20.7 \\
\hline $11 / 27-12,03$ & & 0.941 & 25.31 & 0.61 & 16.5 & 4.61 & 124 & 1.21 & \begin{tabular}{l|l|}
326 \\
\end{tabular} & 3.6 & 98 & 035 & 150 \\
\hline $12 / 04-12 / 10$ & 501 & 1.12 & 30.4 & 0.75 & 202 & 5.2! & 140 & 2.1 & 55.51 & 5.0 & 134 & 0.80 & 21. \\
\hline $12 / 11-12 / 17$ & & 1.19 & 32.3 & 0.771 & 20.7 & 5.5. & 150 & 2.1 & 57.5 & 5.6 & 152 & 0.60 & 16. \\
\hline \multirow{2}{*}{\multicolumn{14}{|c|}{$\frac{12 / 18-12 / 24}{12 / 25-1231}$}} \\
\hline \multirow{2}{*}{\multicolumn{14}{|c|}{$12 / 25-12 / 31$}} \\
\hline & & & & & & & & & & & & & \\
\hline MIN & & 0.19 & 5.1 & 0.00 & 6.0 & 0.2 & 6 & 0.6 & 16.3 & 2.4 & 64 & 0.01 & 0.4 \\
\hline MAX & & 231 & $62.4 !$ & 1.13 & 305 & 7981 & 2156 & 2.1 & 5751 & 7.9 & 214 & 1.81 & 490 \\
\hline MEAN & & 0.74 & 20.4 & 0.47 & 13.1 & 16.1 & 434 & 1.2 & 336 & 4.8 & 129 & 0.67 & 182 \\
\hline STD & & 0.54 & 146 & 0.22 & 5.7 & 193 & 523 & 0.4 & 9.8 & 13 & 35| & 0.29 & 7.9 \\
\hline$N=$ & & 43 & 43 & 43 & 431 & 40 & $40 !$ & 421 & 42 & 44 & 44 & 41 & 41 \\
\hline
\end{tabular}


ANNUAL SLUDGE DATA SUMMARY 1988 thru 1993

(1989-1993includes Uranium Data)

Radionuclide data for Oal Ridge digested slüge

Weetly integrated samples

Data from I.L Larsen, Eovironmental Sciences Division

Data are in pCi/Kg and Bq/Kg wet wh

Note: $1 \mathrm{Kg}$ wet sludge is typically about 1 liter

Note: N.D. not deteeted: Below minimum detection limit

Biank weekly areas indicale no sample

RADIONUCLIDES IN SLUDGE 1993

\begin{tabular}{|c|c|c|c|c|c|}
\hline $\begin{array}{c}\text { Date } \\
\text { Collected }\end{array}$ & WEEK & {$\left[\begin{array}{l}\mathrm{U}-235 \\
\mathrm{BglKg}\end{array}\right.$} & $\begin{array}{l}U-235 \\
\text { PQUK }\end{array}$ & {$\left[\begin{array}{l}\mathrm{U}-238 \\
\text { BquKg }\end{array}\right.$} & $\mid \begin{array}{l}U-238 \\
\text { Paikg }\end{array}$ \\
\hline $12 \sqrt{31-01 \overline{1} 7}$ & 1 & 0.29 & 7.8 & 12.43 & 336 \\
\hline \multicolumn{6}{|l|}{$01 / 08-01 / 4$} \\
\hline $01 / 15-01 / 21$ & & 0.45 & 122 & 13.36 & 361 \\
\hline $01 / 22-01 / 28$ & & NN.D. & N.D. & 13.43 & 363 \\
\hline $01 / 29-0204$ & 3 & 0.33 & 8.8 & 1787 & 483 \\
\hline $0205-0211$ & & 055 & 150 & 1517 & 410 \\
\hline \multicolumn{6}{|l|}{$02 \sqrt{12 /-02 \pi 8}$} \\
\hline $02 / 19-0225$ & & 0.65 & 17.7 & 1765 & 477 \\
\hline $0226-03104$ & & 0.14 & 3.8 & 14.58 & 394 \\
\hline $03105-03 / 11$ & 10 & 0.60 & 162 & 721 & 195 \\
\hline $03 / 12-03 / 18$ & & 0.70 & 188 & 8.40 & 227 \\
\hline $03 / 19-03 / 25$ & & 0.69 & 186 & 26.71 & 722 \\
\hline $03 / 26-04 / 01$ & & 1.04 & 282 & 1709 & 462 \\
\hline $04102-0408$ & & 1.66 & 450 & 29.34 & 793 \\
\hline $04 / 09-04 / 15$ & 15) & & & & \\
\hline $04 / 16-04 / 22$ & & 0.85 & 23.1 & 1469 & 397 \\
\hline $04 / 23-04 / 29$ & & 0.93 & 25.1 & 1820 & 492 \\
\hline $04 / 30-05,06$ & & 0.37 & 100 & 1717 & 464 \\
\hline $05,07-051.3$ & & 0.28 & 7.6 & 8.73 & 236 \\
\hline $05 / 14-0520$ & 20 & 0.49 & 133 & 1580 & 427 \\
\hline $05 \Omega 1-05 \Omega 7$ & & 0.26 & 7.0 & 1391 & 376 \\
\hline $05 / 28-06003$ & & 0.94 & 25.4 & N.D. & N.D. \\
\hline $06104-06 / 10$ & & 0.28 & 7.7 & 0.59 & 16 \\
\hline $06 / 11-06 / 17$ & & N.D. & N.D. & N.D. & N.D. \\
\hline $06 / 18-06 / 24$ & 25 & N.D. & N.D. & N.D. & N.D. \\
\hline $06 / 25-0701$ & & 0.47 & 128 & 15.72 & 425 \\
\hline $07102-0708$ & & 0.64 & 17.4 & 8.88 & 240 \\
\hline $07109-07115$ & & 0.61 & 166 & 15.17 & 410 \\
\hline $07 / 16-07 / 22$ & & 2.09 & 56.5 & 11.43 & 309 \\
\hline $07 / 23-07 / 29$ & 301 & 0.751 & 20.4 & 8.44 & 228 \\
\hline $07 / 30 /-0805$ & & 0.37 & 10.1 & 5.11 & 138 \\
\hline $08 / 06-08 / 12$ & & 0.88 & 239 & 3.77 & 102 \\
\hline $08 \sqrt{13-08 n 9}$ & & 0.73 & 19.7 & 1538 & 421 \\
\hline $08 / 20-08,26$ & & 0.49 & 132 & 6.84 & 185 \\
\hline $08 / 27-0902$ & 35 & & & & \\
\hline \multicolumn{6}{|l|}{$09 / 03-09,09$} \\
\hline \multicolumn{6}{|l|}{$09 / 10-09 / 16$} \\
\hline $09 / 17-09 / 23$ & & 0.56 & 152 & 6.22 & 168 \\
\hline \multicolumn{6}{|l|}{$09 / 24-09 / 30$} \\
\hline $1001-1007$ & 401 & 0.18 & 4.8 & N.D. & N.D. \\
\hline \multicolumn{6}{|l|}{$10,08-10144$} \\
\hline $10 / 15-1021$ & & 0.56 & 152 & 7.95 & 215 \\
\hline $10 / 22-10 / 28$ & & 0.44 & 120 & 7.47 & 202 \\
\hline $10 / 29-11,04$ & & 0.80 & 216 & 9.17 & 248 \\
\hline $1105-11111$ & 45 & 0.27 & 73 & 9.06 & 245 \\
\hline $11 / 12-11 / 18$ & & 0.71 & 19.1 & 12.76 & 345 \\
\hline $11 / 19-11 / 25$ & & 0.44 & 118 & 3.63 & 98 \\
\hline \multicolumn{6}{|l|}{$11 / 26-12,02$} \\
\hline $12003-1209$ & & 0.77 & 208 & 1206 & 326 \\
\hline $12 / 10-12 \pi 6$ & 501 & 0.651 & 176 & 6.36 & 172 \\
\hline $12 / 17-12 / 23$ & & 0.67 & 18.1 & 15.46 & 418 \\
\hline \multicolumn{6}{|l|}{$12 / 24-1230$} \\
\hline & & & & & \\
\hline MIN & & 0.14 & 3.8 & 0.59 & 16 \\
\hline MAX & & 2.091 & 565 & 2934 & 793 \\
\hline MEAN & & .1 .63 & 171 & 1220 & 330 \\
\hline SID & & 0.37 & 9.9 & 5.85 & 158 \\
\hline$N=$ & & 39 & 39 & 38 & 38 \\
\hline
\end{tabular}




\section{B-13}

\section{ANNUAL SLUDGE DATA SUMMARY 1988 thru 1993 \\ (1989-1993 includes Uranium Data)}

Radionuclide data for Oak Ridge digested sludge

Weekly intsegrated samples

Data from I.L Larsen, Environmental Seiences Division

Data are in $p C i / K g$ and $\mathrm{Bq} / \mathrm{K}_{\mathrm{g}}$ wet ot.

Note: $1 \mathrm{Kg}$ wet sludge is typically about 1 liter

Nore: N.D. not detected: Below minimum detection limit

Blank weekly areas indicate no sample

\section{RADIONUCLIDES N.SLUDGE 1993}

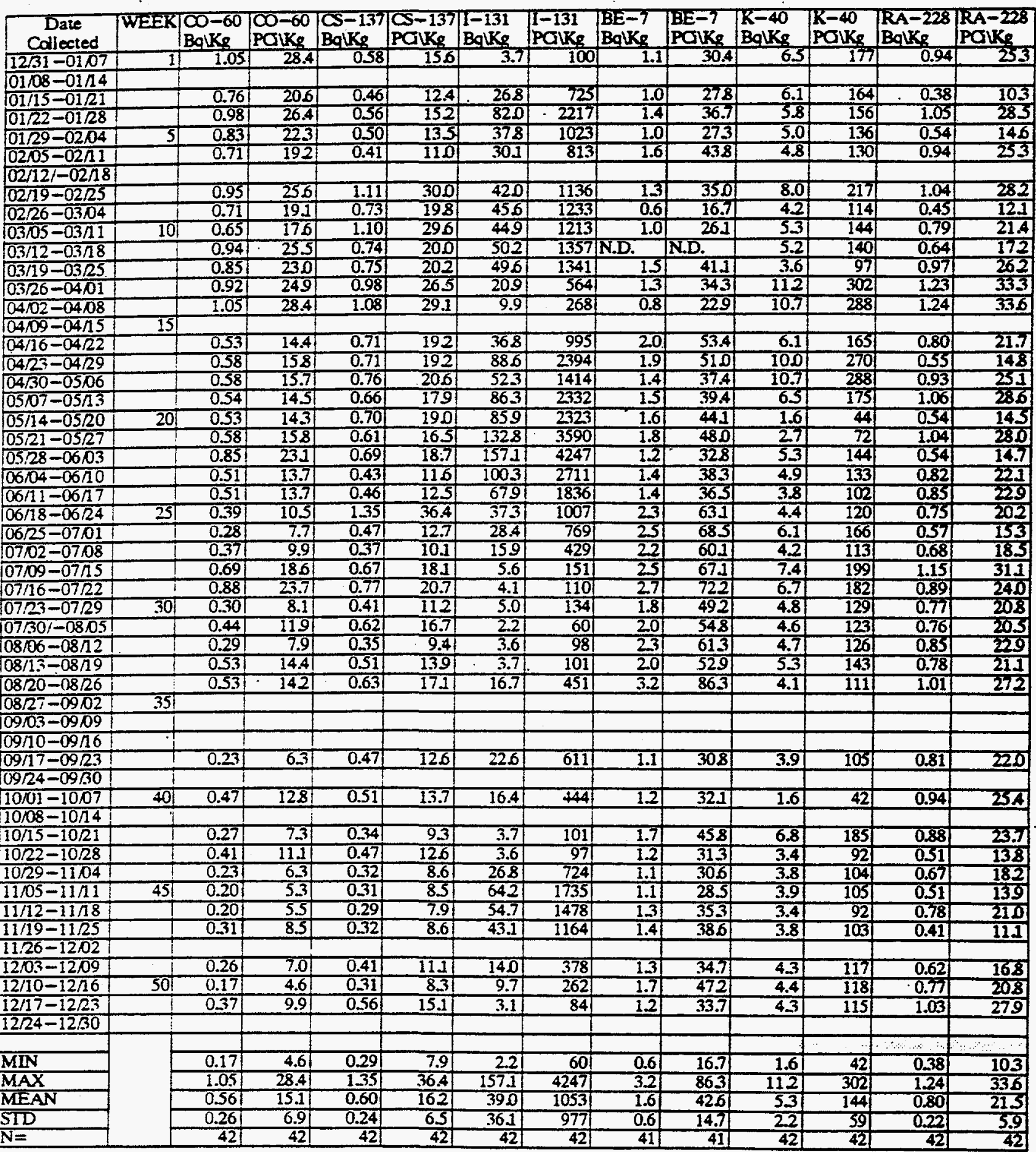

